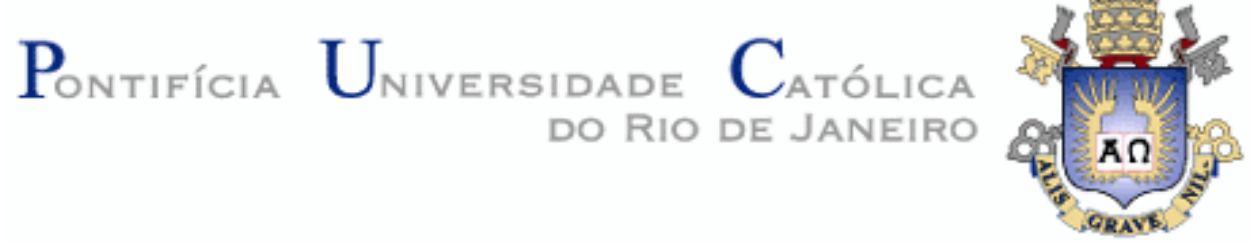

Valtemario Silva Frazão Junior

\title{
Abordagem Contemporânea da Cristologia do \\ Concílio de Calcedônia
}

Tese de Doutorado

Tese apresentada ao Programa de Pós-graduação em Teologia da PUC-Rio como requisito parcial para obtenção do grau de Doutor em Teologia.

Orientador: Prof. Paulo César Costa 


\section{Valtemario Silva Frazão Junior}

\section{Abordagem Contemporânea da Cristologia do Concílio de Calcedônia}

Tese apresentada como requisito parcial para obtenção do grau de Doutor pelo Programa de Pós-graduação em Teologia do Departamento de Teologia do Centro de Teologia e Ciências Humanas da PUC-Rio. Aprovada pela Comissão Examinadora abaixo assinada.

Prof. Paulo Cezar Costa

Orientador

Departamento de Teologia - PUC-Rio

Prof ${ }^{a}$ Maria Clara Lucchetti Bingemer

Departamento de Teologia - PUC-Rio

Prof. Luiz Fernando Ribeiro Santana

Departamento de Teologia - PUC-Rio

Prof. Dorival Souza Barreto Júnior UNIMONTES

Prof. Renato da Silveira Borges Neto

ISTARJ

Profa. Denise Berruezo Portinari

Coordenadora Sentorial de Pós-Graduação e Pesquisa do Centro de Teologia e Ciencias Humanas - PUC-Rio

Rio de Janeiro, 25 de novembro de 2015. 
Todos os direitos reservados. É proibida a reprodução total ou parcial do trabalho sem a autorização da universidade, do autor e do orientador.

\section{Valtemario Silva Frazão Junior}

Graduou-se em Abi - Filosofia pela Universidade Federal do Rio de Janeiro (2006), graduou-se em Teologia pelo Instituto Superior de Teologia da Arquidiocese do Rio de Janeiro (2007) e mestrou-se em Teologia pela Pontifícia Universidade Católica do Rio de Janeiro (2011). Atuando principalmente nos seguintes temas: Concílio de Calcedônia, Fórmula Dogmática, Atualidade.

Ficha Catalográfica

Frazão Junior, Valtemario Silva

Abordagem Contemporânea da Cristologia do Concílio de Calcedônia / Valtemario Silva Frazão Junior ; orientador: Paulo César Costa. - 2015.

216 f. ; $30 \mathrm{~cm}$

Tese (doutorado)-Pontifícia Universidade Católica do Rio de Janeiro, Departamento de Teologia, 2015.

Inclui bibliografia

1. Teologia - Teses. 2. Concílio de Calcedônia. 3. Fórmula dogmática. 4. Atualidade. I. Costa, Paulo César. II. Pontifícia Universidade Católica do Rio de Janeiro. Departamento de Teologia. III. Título. 


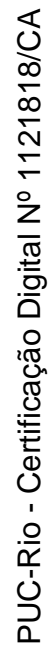

À Santíssima Virgem, com amor filial. 


\section{Agradecimentos}

Ao meu orientador Professor Dr. Dom Paulo Cezar Costa pela atenção, amizade e apoio a mim dispensados.

Aos professores do Departamento de Teologia pelas lições e colaboração para com a Verdade.

Aos funcionários do Departamento de Teologia pela atenção e paciência.

Aos colegas de classe pelo companheirismo e auxílio mútuo.

À CAPES e à PUC-Rio pelos auxilios concedidos, sem os quais esta Tese não se realizaria. 


\section{Resumo}

Frazão Junior, Valtemario Silva; Costa, Paulo Cezar. Abordagem Contemporânea da Cristologia do Concílio de Calcedônia. Rio de Janeiro, 2015. 216p. Tese de Doutorado - Departamento de Teologia, Pontifícia Universidade Católica do Rio de Janeiro.

O concîlio de Calcedônia, o quarto Ecumênico da Igreja, ocorrido em 451, professa e define solenemente a plena humanidade e a plena divindade de Jesus Cristo, Verbo eterno encarnado, articuladas em sua única Pessoa. O grande iniciador da controvérsia que levará à convocação do concílio é o sacerdote Êutiques, que objetivando refutar a heresia de Nestório, cai no erro oposto: o monofisismo. É a partir daí que o concílio de Calcedônia produz uma fórmula dogmática ainda hoje atual. Com efeito, a presente tese, através de uma abordagem histórico-teológica, discorre sobre o tema da cristologia do concílio de Calcedônia partindo da cristologia que lhe é precedente, passando por sua fórmula dogmática até tratar da atualidade do tema no estudo da cristologia contemporânea entre teólogos católicos, protestantes e ortodoxos.

\section{Palavras-chave}

Concîlio de Calcedônia; Fórmula dogmática; Atualidade. 


\section{Abstract}

Frazão Junior, Valtemario Silva; Costa, Paulo Cezar (Advisor). Approach of contemporary Christology the Council of Chalcedon. Rio de Janeiro, 2015. 216p. Doctoral Thesis - Departamento de Teologia, Pontifícia Universidade Católica do Rio de Janeiro.

Council of Chalcedon, fourth ecumenical council of Catholic Church, taken place in 451, professes and defines solemnly the Jesus Christ's wide humanity and wide divinity, eternal incarnated Logos, combined in just one Person. The responsible for all the controversy that will be the key to the Council is the presbyter Eutyches, whose ideas to refuse Nestorian heresy fell in the opposite mistake: monophysitism. From that moment on, the Council creates a dogmatic formula, still current. The present thesis, throughout a historical and theological approach, developes the Christology theme of Council of Chalcedon, from preceeded Christology, through its dogmatic formula, until the currency of the theme in the analyzation of contemporain Christology between Catholics theologians, Protestants and Orthodox.

\section{Keywords}

Council of Chalcedon; dogmatic formula; currency. 


\section{Sumário}

1 Introdução 11

2 Cristologia Pré-calcedoniana 18

2.1 Clemente Romano 18

$\begin{array}{lr}2.2 \text { Cristologia Antioquena } & 19\end{array}$

2.3 Teologia do Logos 20

2.4 Cristologia de Justino $\quad 26$

$\begin{array}{ll}2.5 \text { Cristologia de Irineu } & 27\end{array}$

$\begin{array}{ll}2.6 \text { Cristologia Adopcionista } & 29\end{array}$

2.7 Cristologia do Logos de Hipólito 30

2.8 Cristologia do Logos de Tertuliano 31

2.9 Cristologia de Orígenes $\quad 34$

2.10 Ário e o concílio de Nicéia I (325) 38

2.11 Apolinário de Laodicéia 42

2.12 Controvérsia nestoriana $\quad 44$

3 O Concílio de Calcedônia 48

3.1 O "latrocínio" de Éfeso $\quad 51$

3.2 O Tomus ad Flavianum $\quad 55$

3.3 O concílio de Calcedônia $\quad 62$

$\begin{array}{ll}3.4 \text { A definição de Calcedônia } & 64\end{array}$

3.5 A cristologia da Fórmula de Calcedônia 68

3.6 A recepção imediata no Ocidente e Oriente $\quad 72$

4 A Cristologia calcedoniana Católica $\quad 74$

4.1 Da Reforma Protestante a R. Bultmann e K. Rahner 74

$\begin{array}{ll}\text { 4.1.1 Rudolf Bultmann } & 75\end{array}$

$\begin{array}{ll}\text { 4.1.2 Karl Rahner } & 77\end{array}$

4.2 Piet Schoonenberg 83

4.2.1 A Fórmula de Calcedônia e a crítica de Schoonenberg 84

$\begin{array}{ll}4.3 \text { Edward Schillebeeckx } & 88\end{array}$

4.3.1 A identificação hipostática $\quad 91$

4.4 Walter Kasper 93

4.4.1 A mitificação da verdadeira imagem de Jesus 95

4.4.2 A Fórmula de Calcedônia e suas limitações históricas 96

4.5 Bernard Sesboüé $\quad 99$

4.5.1 Uma cristologia à luz de Calcedônia 101

$\begin{array}{ll}\text { 4.6 Joseph Moingt } & 102\end{array}$

$\begin{array}{lr}4.7 \text { Hans Küng } & 107\end{array}$

$\begin{array}{ll}4.8 \text { Jon Sobrino } & 110\end{array}$

4.8.1 Falta de concreção 111

4.8.2 Falta de historicidade 112

4.8.3 Falta de Relacionalidade $\quad 114$

4.8.4 As afirmações doxológicas da fórmula de Calcedônia 116

5 Cristologia Calcedoniana Protestante 119

$\begin{array}{lr}5.1 \text { Wolfhart Pannenberg } & 119\end{array}$ 
5.1.1 A história universal e a revelação veterotestamentártia 120

5.1.2 A crítica de Pannenberg 124

5.2 Jürgen Moltmann 126

5.2.1 Cristologia da ressurreição de Jesus $\quad 126$

5.2.2 A ressurreição e a promessa escatológica 128

$\begin{array}{ll}\text { 5.2.3 Cristologia da Cruz } & 129\end{array}$

$\begin{array}{ll}\text { 5.2.4 Cristologia política } & 131\end{array}$

$\begin{array}{ll}\text { 5.3 Paul Tillich } & 132\end{array}$

5.3.1 Os riscos presentes no desenvolvimento do dogma cristológico 135

$\begin{array}{ll}\text { 5.3.2 A cristologia na atualidade } & 137\end{array}$

5.3.3 A natureza divina e a natureza humana 138

6 Cristologia Calcedoniana Ortodoxa 143

6.1 Paul Evdokmov 143

6.1.2 A cristologia russa nos séculos XIX e XX 144

6.1.3 A perspectiva filosófica na teologia russa dos séculos XIX e XX 146

6.1.4 A cristologia russa 148

6.1.5 A cristologia em Paul Evdokimov 150

6.1.6 O Verbo encarnado como lugar de encontro do divino com o humano 151

6.1.7 Indivíduo e Pessoa $\quad 154$

6.1.8 A deificação do ser humano em Paul Evdokimov 155

$\begin{array}{ll}\text { 6.1.9 A deiformidade humana } & 157\end{array}$

6.2 Paul Gavrilyuk 160

6.2.1 As três vias cegas 162

6.2.2 A impassibilidade divina no arianismo e no nestorianismo 165

6.2.3 A Theopatheia de Cirilo 167

6.2.4 O Verbo unigênito de Deus, sujeito da kênosis 170

6.2.5 A impassibilidade divina e a construção da doutrina da encarnação

6.3 Vladimir Lossky

6.3.1 A natureza humana de Jesus Cristo

6.3.2 A divina humanidade de Jesus 184

7 Epílogo 192

7.1 Novos caminhos para o estudo do Jesus Histórico 194

7.2 Alguns aspectos a considerar 195

7.3 O retorno ao dado bî́blico do Novo Testamento 198

7.4 O concílio de Calcedônia e o Ecumenismo 199

7.5 A lgreja Nestoriana 200

7.6 A lgreja Monofisita 201

7.7 Diálogo e declarações ecumênicas 202

8 Referências bibliográficas 208

8.1 Fontes 208

8.2 Documentos da Igreja 209

8.3 Obras 209

8.4 Artigos 215 


\section{Abreviaturas}

GS Gaudium et Spes

HG Humani Generis

MF Mysterium Fidei

DS Denzinger

SR PIO XII. Sempiternus Rex

UR Decreto Unitatis Redintegratio 


\section{1 \\ Introdução}

Em Mt 16, 13-17 Jesus antes de prometer a Simão Pedro o governo da Igreja, perguntou aos seus discípulos qual a opinião que tinham eles e o povo a respeito de sua pessoa. Em seguida, exalta a resposta de fé dada pelo Príncipe dos Apóstolos, que diante de sua interpelação Ihe diz: "Tu és Cristo, Filho de Deus vivo" (Mt 16,16). Estafé expressa pela boca de Pedro e que sempre foi fé da lgreja atravessa os primeiros séculos vencendo perseguições e tempestades até ser vigorosamente defendida e exposta principalmente em três concílios ecumênicos: Nicéia, Éfeso e Calcedônia.

Contudo, é precisamente sobre o grande concílio de Calcedônia que pretendemos nos debruçar em nossa tese de doutorado. Em nossa dissertação de mestrado abordamos o concílio de Calcedônia considerando-o atentamente em si mesmo e nas suas circunstâncias, o que nos possibilitou uma melhor compreensão do grandíssimo alcance da sua definição dogmática. Agora queremos então elucidar suas perspectivas hodiernas e nelas nos aprofundar.

O referido concílio, o quarto Ecumênico da Igreja ocorrido em 451, que professa e define solenemente como se conjugam a plena humanidade e a plena divindade de Jesus Cristo, Verbo eterno encarnado, articuladas em sua única Pessoa, a segunda da Santíssima Trindade, teve como iniciador de sua controvérsia o sacerdote Êutiques, que objetivando refutar a heresia de Nestório, que afirmava haver duas pessoas em Cristo, cai no erro oposto ao afirmar que se deviam distinguir dois momentos na economia salvífica: antes da encarnação, quando então as naturezas de Cristo eram duas, a divina e a humana; e depois da encarnação quando então existe uma só natureza, sendo o homem absorvido pelo Verbo. Outro ponto principal de grande importância que o concílio toca e que se faz mister na resolução da agitada controvérsia cristológica é a questão do primado do Romano Pontífice que não trataremos em nossa tese.

Com efeito, a definição dogmática de Calcedônia constitui nova atualização do mistério revelado de Jesus Cristo, em plena conformidade com a tradição da Igreja, acrescentada apenas de algumas cláusulas explicativas. Podemos dividila em duas partes, em que na primeira há uma retomada do "Ato de União" do ano 433, e na segunda há esclarecimentos ulteriores, a partir de conceitos helenistas. 
A definição toma como ponto de partida a união da divindade com a humanidade em Jesus, a partir daí estabelece a distinção das duas naturezas: consubstancial ao Pai, quanto à divindade, e a nós quanto à humanidade ${ }^{1}$. Frente ao perigo reducionista do monofisismo, era mister ratificar e acentuar a consubstancialidade a nós na humanidade. De modo que assim se pudesse salvaguardar a doutrina tradicional da lgreja e responder à questão suscitada por Êutiques. Contudo, podemos perceber que o termo "consubstancial" aplicado às duas naturezas não possui o mesmo significado. Pois, se quanto à divindade, afirma-se a consubstancialidade numérica do Pai com o Filho, o que, diga-se de passagem, não foi afirmado pelo Concílio de Nicéia, no caso da humanidade proíbe-se, como é natural, esta consubstancialidade numérica de Jesus conosco, pois se Jesus é um só Deus com o Pai, é evidente que não é um só homem conosco, por mais que se tenha unido intimamente a cada um dos homens ${ }^{2}$. À luz da escola de Antioquia, o final da primeira parte da definição calcedoniana destaca a dupla origem de Cristo, gerado pelo Pai desde toda a eternidade, como Deus, e gerado no seio de Maria, no tempo como homem. Assim, a definição se aproxima claramente do esquema de Éfeso, referindo-se à história e à motivação soteriológica que levou o Verbo Eterno de Deus a seencarnar fazendo-se homem. Neste sentido, a dupla consubstancialidade com o divino e o humano, implicada pela motivação soteriológica, é também ressaltada pelo título de Theotokos dado a Maria.

Já a segunda parte da definição de Calcedônia traz consigo outras explicações em linguagem filosófica com o objetivo de expressar como coexistem unidade e distinção na única pessoa de Cristo. A propósito, neste ponto se distinguem os conceitos de pessoa (hipostasis, prosopon) e natureza (physis), afirmando contra Êutiques que o mesmo Senhor e Cristo, o Filho unigênito, é uno em duas naturezas, sem confusão nem mudança, e, contra Nestório, sem divisão nem separação.

A permanência da dualidade das duas naturezas após a união é elucidada pela expressão "em duas naturezas". Pois quer dizer que Cristo não é apenas de duas naturezas, como queria Êutiques, mas é também em duas naturezas. Desta maneira, a união hipostática do Verbo Eterno com a nossa humanidade mantém a alteridade da humanidade na mesma e única pessoa. A humanidade de modo nenhum é absorvida pela divindade, como defendia o sacerdote Êutiques. Eainda, "sem confusão nem mudança", destaca que a distinção das duas naturezas não

\footnotetext{
${ }^{1}$ A consubstancialidade a nós é abordada na Fórmula de União de 433.

${ }^{2}$ GS 22.
} 
somente permanece como também se conservam as propriedades de cada uma delas. "Sem divisão nem separação" significa que as duas naturezas não apenas se justapõem como se fossem sujeitos subsistentes distintos. As propriedades de cada uma das naturezas ficam salvaguardadas de modo a confluírem na única pessoa de Jesus que age como Deus e como homem exatamente por ser simultaneamente Deus e homem.

Neste sentido, a definição calcedoniana aborda com uma impostação antioquena a união hipostática que o Concilio de Éfeso expressou de maneira alexandrina. Tal paradigma de união da divindade com a humanidade na única pessoa de Jesus Cristo revelava-se algo realmente singular, porém somente uma união nestas condições é capaz de se coadunar com a sua função de único mediador entre Deus e a humanidade.

Muitas vezes no passado, e ainda hoje, surgem questionamentos em torno da resolução ontológica do mistério de Jesus Cristo, a respeito de sua real necessidade e utilidade. Não seria possível exprimir a fé simplesmente a partir de uma linguagem funcional abrindo-se mão da terminologia ontológica? É o questionamento levantado por muitos teólogos a partir do advento da Modernidade, sendo Lutero o precursor em propor um significativo questionamento à cristologia de Calcedônia, de modo a tornar este patrimônio dogmático acessível ao homem moderno.

Com efeito, se no passado era necessário o encontro da fé calcedoniana com o pensamento helenístico de consequências longínquas, hoje, mais do que nunca, há que ocorrer uma reorientação da cristologia no horizonte do pensamento atual. $O$ próprio contributo da perspectiva histórica, fortemente presente no pensamento do século $X X$, tem ajudado bastante a explicitar a identidade divino-humana de Jesus, confessada pelo Novo Testamento, pelos símbolos batismais e pelas fórmulas dogmáticas, tornando a teologia dogmática mais acessível ao homem de hoje. Neste sentido, a influência do pensamento histórico libertou a cristologia de sua paralisia e colocou em evidência a necessidade de uma renovação constante e de um corajoso esforço de reflexão nova. Além disso, o pensamento histórico da atualidade exerce também uma influência imediata na transformação interna da cristologia.

Ora, se esta perspectiva histórica é capaz de influenciar e até mesmo provocar uma transformação interna da cristologia, a fórmula dogmática de Calcedônia, não poderia fugir da regra. De modo que a fé do Concílio de Calcedônia é atualmente abordada sob o prisma do pensamento histórico por diversos autores de diferentes impostações cristológicas, o que nos atesta que a 
definição de Calcedônia é ainda objeto de um debate cristológico vigoroso, visto que marcou um progresso que se abre para outros progressos, permanecendo, assim, inacabada. Entretanto, em nível de corte epistemológico, em nosso trabalho nos limitaremos a refletir a atual tendência no que tange a questão, ou seja, a maneira como o tema é hoje abordado pelas igrejas católica, protestante e ortodoxa, a partir da ótica e do esboço cristológicos dos principais ícones da cristologia moderna/pós-moderna. Entre os católicos temos Piet Schoonenberg, Edward Schillebeeckx, Walter Kasper, Bernard Sesboüé, Joseph Moingt, Hans Küng e Jon Sobrino; entre os protestantes Wolfhart Pannenberg, Jürgen Moltmann e Paul Tillich; e por fim entre os ortodoxos, Paul Evdokimov, Paul Gavrilyuk e Vladimir Lossky. Tais autores não compreendem a cristologia atual como outrora, ou como uma cristologia de encarnação e essencialista, que dissimulava demasiadamente as dimensões da existência terrena e humana de Jesus. Agora surgem em primeiro plano as categorias dinâmicas e funcionais e as categorias históricas.

As afirmações escriturísticas acerca de um crescimento interno do jovem Jesus de Nazaré, da sua fé e da sua obediência, justamente revelam esta história interna por muito tempo esquecida e esta historicidade da vida de Jesus. É preciso, por exemplo, ser seriamente consideradas as tentações e provações de Jesus, que se estendem até a cruz e são contadas várias vezes nos evangelhos, se quisermos realmente compreender a sua caminhada histórica feita de obediência. Elas aparecem como manifestações externas de um diálogo muito intenso entre o Filho de Deus feito homem e o Pai celeste, de modo que na sua fé, na qual se entrega ao Pai, Jesus vive o seu ser divino e eterno de Filho e com isso se torna o lugar em que aparecem o amor e a fidelidade de Deus neste mundo ${ }^{3}$.

Dessa maneira, o ponto de partida para nós não é mais a encarnação e a unidade de Jesus com Deus, mas a realização histórica dessa unidade na relação concreta de Jesus com Deus; relação que só encontra sua clareza e sua consumação no evento da cruz e da ressurreição.

Visto que o Concílio de Calcedônia legou ao Povo de Deus uma consistente fórmula cristológica, ainda atual, pretendemos em nossa obra tratar a fórmula dogmática calcedoniana através de uma abordagem histórico-crítico-dogmática. Pois reconhecemos o perigo de se absolutizar o valor das fórmulas dogmáticas, 0 que poderia levar à compreensão equivocada de que a definição cristológica de 
Calcedônia, ou de qualquer outro concílio, seja a única maneira possível de enunciar o mistério de Jesus Cristo e, por isso mesmo, a única válida para todos os tempos e lugares. Neste sentido, o método histórico-crítico-dogmático nos será de grande valor, visto que ele compreende que os enunciados dogmáticos são condicionados pelo tempo e pelo espaço do ambiente cultural em que foram concebidos e solenemente proclamados. Sem dúvida alguma são válidos e permanecem como tais dentro dos parâmetros daquela cultura e daquele contexto histórico em que foram necessários, e ainda em nossos dias integram a memória da lgreja permanecendo como referência para a produção cristológica atual.

Com efeito, o seu objetivo era afirmar o significado do mistério através de conceitos precisos capazes de comunicá-lo de alguma maneira, embora se saiba que o seu significado ultrapassa os limites dos termos utilizados. Contudo, o que de fato deve ser preservado não são as fórmulas em si mesmas, mas sim o seu sentido profundo.

No entanto, a cultura está sempre aberta à evolução, pois o sentido dos conceitos é flexível às mudanças. $E$ tratando-se de evolução cultural, em que muitas vezes a mensagem cristã deve se encarnar em culturas diferentes daquelas em que foi primeiramente concebida, a fidelidade ao propósito inicial e ao significado das fórmulas tradicionais, ainda mais às dogmáticas, pode exigir expressões novas na exposição desse mesmo significado, o que gera a possibilidade real de um prudente pluralismo dogmático que, diga-se de passagem, jamais poderá ser confundido com relativismo dogmático, pois considerar uma fórmula dogmática como relativa e não absoluta não equivale relativizar a verdade nem lhe recusar a objetividade. Se bem que o magistério autorizado da lgreja nem sempre reconhece, pelo menos abertamente, o caráter relativo das fórmulas dogmáticas. É o que nos recorda Pio XII ao condenar o "relativismo dogmático" na encíclica Humani Generis de $1950^{4}$ com o intuito de resguardar o valor absoluto das definições dogmáticas da lgreja. $E$ mais recentemente Paulo VI na encíclica Mysterium Fidei de 1965, na qual defende o valor permanente, imutável e universal das formulações dogmáticas fruto de conceitos derivados da experiência humana universal e, precisamente por isso, contrárias à mudança cultural ${ }^{5}$.

Porém, João XXIII no discurso de inauguração da primeira sessão do Concílio Vaticano II nos advertia para o fato de que uma coisaé o próprio depósito da fé, isto é, as verdades expressas em nossa doutrina, e outra coisa é a forma 
na qual elas vêm enunciadas, desde que conservem o mesmo sentido e o mesmo alcance ${ }^{6}$. Assim, o Pontífice reconhecia uma possível pluralidade das formulações dogmáticas, o que será posteriormente apropriado pelo Concílio Vaticano II na Constituição Gaudium et Spes: “(...) uma coisa é o próprio depósito da fé ou as verdades e outra é o modo de enunciá-las, conservando-se contudo o mesmo significado e a mesma sentença" (GS 62).

Ainda vale a pena recordar a Declaração Mysterium Ecclesiae de 1973 da Sagrada Congregação para a Dourtina da Fé que estabelece como realidades distintas o sentido das fórmulas dogmáticas, que permanece sempre o mesmo, e as próprias fórmulas que, em si mesmas, dependem de condicionamentos históricos e, precisamente por isso, podem exigir enunciados novos e mais profundos ${ }^{7}$.

Sendo assim, pelo que até aqui afirmamos somos levados a reconhecer que é realmente possível um pluralismo dogmático, que muitas vezes se faz necessário em situações de mudança cultural, desde que as novas formulações não alterem o significado das primeiras.

Acreditamos que a motivação primordial dessas propostas cristológicas seja a inculturação da fé em Jesus Cristo, num contexto de evolução cultural até mesmo de encontro com outras culturas. Não poucas vezes a inculturação doutrinária tem sido o aspecto mais problemático no processo de encarnação do cristianismo nas diferentes culturas, visto que ela toca em delicados problemas hermenêuticos.

Assim, percebemos um dos grandes desafios da cristologia atual: manterse vinculada seja à continuidade seja à descontinuidade na profissão da fé cristológica. Continuidade na identidade de sentido e descontinuidade na mediação dos conceitos. Pois temos evidenciado mais claramente que a dialética continuidade-descontinuidade constitui aspecto imprescindível do atual discurso cristológico.

Através dessa abordagem ou método histórico-crítico-dogmático pretendemos o quanto possível atingir o nosso objetivo de considerar a recepção hodierna da fé proclamada no Concílio de Calcedônia a partir das atuais categorias cristológicas. Para tanto pretendemos articular cinco capítulos. No primeiro capítulo abordaremos a teologia que antecede e, em certo sentido, prepara o Concílio de Calcedônia: a teologia do Logos, que encontra seus fundamentos na teologia joanina, mais precisamente no prólogo do quarto

\footnotetext{
${ }^{6}$ João XXIII, IV, 5.
}

${ }^{7}$ DS n. 4540. 
Evangelho; os concílios de Nicéia (325), Constantinopla (381) e Éfeso (431). No segundo capítulo trataremos propriamente da questão do Concílio de Calcedônia e sua fórmula dogmática, sua elaboração, suas partes, suas fontes e, sobretudo, os seus elementos teológicos, bem como sua recepção imediata nos decênios seguintes. No terceiro, quarto e último capítulos trataremos das atuais abordagens da Fórmula de Calcedônia respectivamente nas cristologias católica, protestante e ortodoxa, ou seja, da sua recepção hodierna entre os principais teólogos das três grandes denominações cristãs; de modo que possamos assim considerar séria e profundamente as categorias cristológicas atuais a partir das perspectivas históricas às quais aludimos até aqui, bem como perceber e examinar os pontos que podem contribuir para uma recepção renovada do Concílio de Calcedônia, de maneira que a sua definição cristológica seja de fato acessível às pessoas do nosso século tocando-lhes a existência a partir da consciência de sua mais autêntica identidade cristã. 


\section{2 \\ Cristologia Pré-calcedoniana}

Pode-se afirmar com toda serenidade que no Novo Testamento percebemos duas tendências bem definidas de cristologia que se desenvolvem em diferentes regiões. Estas duas tendências são costumeiramente definidas como Cristologia do alto e Cristologia do baixo. Tais tendências são fruto da diversidade de posturas cristológicas que encontramos no interior de algumas comunidades que se desenvolvem conforme as diversas regiões. Há aquela mais ligada a tradição judaica, que reconhece Jesus Cristo apenas como um homem excepcional, que no segundo século se desenvolverá no ebionismo, que se estenderá até o século III; e há ainda aquela outra tendência que reconhecia em Jesus uma figura angélica. Somente em nível de ilustração recordemos que praticamente durante todo o primeiro capítulo da Carta aos Hebreus o autor se opõe a esta cristologia quando diz que Cristo é superior aos anjos ( $\mathrm{Hb}$ 1,4-14). Tal postura será ainda posteriormente encontrada no Pastor de Hermas, quando apresenta Jesus superior aos homens, contudo sua grandeza não pode prejudicar a unidade de Deus. Neste sentido a categoria de anjo é utilizada para identificá-lo. Uma terceira tendência pode ser encontrada ainda na Carta aos Hebreus e no corpo joanino, onde percebemos o pensamento segundo o qual, a despeito de ser homem, o mistério da pessoa de Jesus ultrapassa a sua humanidade, e ele é assim inserido no âmbito da divindade, de modo que ele não é somente humano, mas é também um ser divino, provindo efetivamente do mundo da divindade. Jesus é então definido como $\theta \varepsilon o ́ s$. Esta tendência depara-se com o grande desafio de conciliar a divindade de Jesus com a unicidade de Deus. Visto que João afirma categoricamente a divindade de Jesus Cristo: "Eu e o Pai somos um" (Jo 10,30).

\section{1}

\section{Clemente Romano}

A carta de Clemente Romano é de suma importância para o conhecimento da teologia do fim do século I. Nesta obra Cristo é chamado de Senhor, e sua função de mediador ${ }^{8}$ é significativamente sublinhada como intercessor entre Deus

\footnotetext{
${ }^{8}$ GRILLMEIER, A. Gesú il Cristo nella fede della chiesa.
} 
e os homens, como podemos depreender logo de sua introdução ${ }^{9}$. Neste sentido, ao destacar a função mediadora de Cristo, Clemente parece-nos afirmar a Sua preexistência a encarnação, principalmente em 1 Clem 16,2: "O cetro da majestade de Deus, nosso Senhor Jesus Cristo, não veio com ares de arrogância e orgulho, muito embora assim pudesse ter feito, mas com humildade, como, sobre ele, o Espírito Santo anunciou". O que nos leva a perceber aí considerável inclinação para uma cristologia do alto.

\section{2 \\ Cristologia Antioquena}

Judeo-cristãos helenistas de Jerusalém, provenientes de Chipre e da Cirenaica, pregaram em Antioquia o Evangelho com admiráveis frutos ao ponto de fazer desta cidade um dos maiores centros do cristianismo nos séculos I e II. Aí também se desenvolve uma cristologia do alto, cujo primeiro grande expoente será Inácio de Antioquia, conhecido por suas cartas escritas às lgrejas quando era conduzido a Roma a fim de aí sofrer o martírio no reinado de Trajano.

A despeito de suas cartas não se tratarem de tratados teológicos, percebese nestes textos afinidades com o quarto Evangelho e com a primeira carta de João e ainda certa influência das cartas paulinas, particularmente 1Coríntios e Efésios, e também das cartas pastorais ${ }^{10}$, o que coloca sua cristologia na mesma linha de Paulo e de João, definida como cristologia do alto. Todavia, por outro lado observa-se certa distância dos demais textos do Novo Testamento, precisamente quando Cristo é definido Deus (Téos) com toda espontaneidade (cf. Rm 6,3). Ele afirma não menos espontaneamente a preexistência do Filho à encarnação.

Esforçai-vos por fazer tudo na harmonia de Deus, sob a presidência do bispo em lugar de Deus e dos presbíteros em lugar do colégio dos apóstolos e dos diáconos, particularmente queridos, encarregados do serviço de Jesus Cristo, o qual antes dos séculos estava com o pai e nos últimos tempos se manifestou (Mag. 6,1) ${ }^{11}$.

É em Inácio que se encontra pela primeira vez o termo Logos na reflexão teológica fora do corpo joaneu. O bispo de Antioquia tem diante de si uma das mais antigas problemáticas da fé cristã, isto é, a tendência em se minimizar a realidade da humanidade de Cristo, seus sofrimentos e sua morte, ao intencionar resguardar a integridade de sua divindade. Esta tendência mais tarde se desenvolverá no século II em formas mais populares, como em certos Evangelhos

\footnotetext{
${ }^{9}$ CLEMENTE ROMANO. Carta aos Coríntios.

${ }^{10}$ LIÉBAERT, J. Os Padres da Igreja., p.25.

${ }^{11}$ RUIZ BUENO, D. Padres Apostólicos., p.462.
} 
apócrifos, ou em formas mais sistemáticas, como na gnose, ao ponto de reduzir a encarnação a mera aparência, ou uma aparição de Deus sob forma humana. Assim o docetismo ganha espaço tornando-se a grande heresia cristológica do século II. Por isso, Inácio tanto insiste em suas cartas para que as comunidades creiam na realidade da encarnação, paixão e ressurreição de Cristo, mas que creiam considerando também como realidade a sua divindade e humanidade, como fundamento de todo o mistério cristão em dizeres que de modo profético anunciam os futuros símbolos de fé ${ }^{12}$.

O docetismo (do verbo dokein; ter a aparência; parecer), que já se encontra presente no corpo joaneu, ao tender subestimar a realidade histórica da obra salvífica de Deus contribuirá de maneira decisiva para que o gnosticismo e o marcionismo também desprezem a carne e professem que Cristo não sofreu realmente, mas somente em aparência ${ }^{13}$. Diante disto, Inácio testemunha de modo autêntico a fidelidade da lgreja antiga ao mistério de Cristo.

O que podemos depreender do que já foi dito até aqui é que o docetismo surgirá em ambientes onde se desenvolve uma cristologia do alto.

\section{3 \\ Teologia do Logos}

O termo Logos, no sentido cristão significa a Palavra, o Verbo de Deus encarnado em Jesus Cristo. No Novo Testamento o termo Logos aparece três vezes, mais precisamente no corpo joanino (Jo 1,14; 1Jo 1,1; Ap 19,13).

A palavra grega logos possui vários significados. Aqui nos interessa recordar que ela significa, no contexto bíblico, "palavra" e "pensamento".

$\mathrm{Na}$ filosofia grega, desde Heráclito (535-465 a.C.) a palavra logos foi utilizada por diversas escolas filosóficas gregas. Os estóicos compreendiam o logos como o princípio divino que penetra e sustenta o mundo. Para Fílon de Alexandria, teólogo judeu de cultura helênica, o logos era a inteligência divina (nous), um "segundo deus"14, noção que será mais tarde assimilada pela teologia de Orígenes.

Existe um considerável consenso de que a noção neotestamentária de Palavra de Deus, e especialmente no Prólogo do IV Evangelho (Jo 1,1-18), seria em parte influenciada pela doutrina de Fílon. Porém, o autor do IV Evangelho teria corrigido a doutrina de Fílon acentuando a igualdade de essência entre o Pai e o

\footnotetext{
${ }^{12}$ cf. Carta à Esmirna 1, 1-2; LIÉBAERT, J. Op.cit., pp.25-26.

${ }^{13}$ ORBE, A. Cristologia Gnóstica., pp.380-412.

${ }^{14}$ DE FRAINE, J. Logos., p.899.
} 
Logos. Talvez ele quisesse polemizar contra determinadas idéias gnósticas já divulgadas na Ásia menor ( $\mathrm{Cl} 2,18 ; 1 \mathrm{Tim} 1,14 ; \mathrm{Ti} 1,14 ; 3,9)$ que negavam ou comprometiam a divindade de Cristo ${ }^{15}$.

A teologia do Logos em João é ápice da cristologia neotestamentária e, por este motivo, Jo 1,14 concentrou sempre sobre si a atenção dos Padres da lgreja ${ }^{16}$. Jesus de Nazaré surge como a definitiva Palavra de Deus dirigida aos homens, como o único e absoluto revelador e enviado de Deus que supera todos os profetas. Só ele pode revelar os bens celestiais (Jo 1,18). Ele não é só legislador como Moisés, mas é também o dispensador da graça e da verdade. Nele está presente o próprio Deus (14,9). O objeto de sua revelação não é apenas o Pai, mas também a sua própria pessoa e missão. Ele se auto-descreve como luz e vida do mundo, e de forma absoluta ego eimi $(8,24-28.58 ; 13,19)$. Esta última é uma formulação característica das teofanias. A atividade reveladora e a inteira missão de Cristo é apresentada no IV Evangelho em um movimento de descida e subida, e também como um procedimento judiciário entre Deus e o mundo que lhe é inimigo. Enquanto o esquema da descida teve grande importância na Era patrística, o segundo praticamente não foi levado em consideração ${ }^{17}$.

A encarnação do Logos descrita em Jo 1,14 se tornou um ponto central na interpretação da pessoa de Jesus. Tal valorização pode ser compreendida pela importância dos termos logos e sarx no contexto da evangelização dos povos de cultura grega. Trata-se da inculturação do Evangelho, iniciada ainda durante a elaboração dos escritos neotestamentários, e que continuou durante a Era patrística.

O corpo dos escritos joaninos, pela primeira vez na literatura cristã, qualifica a pessoa de Jesus Cristo com o nome Logos, que será repetido inumeráveis vezes pela teologia de tradição grega, e traduzido para outras línguas, mesmo que não conserve mais a força expressiva de sua origem.

O primeiro elemento presente no conceito joanino de Logos é a idéia da "revelação" e do "revelador" Jesus Cristo. Jesus é a Palavra de Deus que existe antes mesmo da criação do mundo e que com a criação e a encarnação é pronunciada no mundo.

A tarefa de "revelador" é estritamente ligada à pessoa de Jesus que se tornou a revelação personificada do Pai. Não só as palavras de Jesus, mas o fato de sua missão e da sua origem são por si mesmas uma auto-revelação divina. Em

\footnotetext{
15 lbid.

${ }^{16}$ GRILLMEIER, A. Gesù Cristo nella fede della Chiesa., p.169.

17 lbid., pp.169-171.
} 
Ap 19,11-16 a perícope do enviado divino é expressa pela imagem do cavaleiro branco, cujo nome é Palavra de Deus. A sua missão é expressa por seu nome. Em Jo 1,14, o Logos é apresentado, em primeiro lugar como "palavra pronunciada" em oposição a logos como racionalidade, conforme compreensão helenística da época. Próprio desta perspectiva está o relacionamento entre o Logos e a atividade do revelador. Um outro tipo de revelação entre Jesus e a sua missão não se pode retirar de 1Jo 1,3, embora seja controvertido se "logos" aqui está relacionado à pessoa de Jesus ou à sua doutrina, embora se possa compreender as duas coisas. Trata-se de uma continuação dos temas do prólogo. O conteúdo do termo "logos" não é definido por ele próprio, o que significa que uma definição puramente funcional é insuficiente.

As fontes da teologia joanina são procuradas muito freqüentemente no Antigo Testamento, mas apenas o termo "Logos" veterotestamentário não contém o tema de revelação de Deus, nem a idéia de palavra como força e sabedoria, que se revelam nas forças cósmicas de Deus, além do mais falta ainda ao Antigo Testamento a idéia de uma palavra "pessoal"18.

A doutrina veterotestamentária de sabedoria nos permite compreender que a "sabedoria" do AT e o Logos do IV Evangelho, malgrado não serem equivalentes, possuem algum ponto em comum. Ambos existem desde o início (Pv 8,32; Eclo 24) e estão junto de Deus (Pv 8,23-25.30). Ambos agem no mundo. Mas em Jo1,14 o Logos faz a sua tenda entre os homens. A relação entre o prólogo joanino e Pv 8,22 e Eclo 24 é tão estreita que se pode falar de uma dependência literária. A.Grillmeier crê que no IV Evangelho não se conservou o vocativo sophia e optou-se por Logos devido a identificação rabínica da "sabedoria" com a Torah. É provável que o gênero feminino de sophia e o seu lugar nas especulações gnósticas não recomendassem o seu uso no mundo da cultura grega ${ }^{19}$. Mas onde os livros do Antigo Testamento viam apenas a personificação poética de um atributo divino, o IV Evangelho vê o Verbo de Deus, Filho unigênito do Pai, expressão cabal da sabedoria divina, pelo qual tudo foi criado $^{20}$.

Também as fórmulas, os hinos e as idéias do Novo Testamento teriam exercido influência em João. Em 1Cor 1, 24 Cristo é apresentado como "potência" e "sabedoria" de Deus, sem, contudo, tratar da essência de Cristo, mas apresentando uma definição desenvolvida na economia da salvação, e

\footnotetext{
18 Ibid., p.173s.

19 lbid., p.175.

20 TERRA, J. E. M. Prólogo de São João (1,1-18)., p.12.
} 
qualificando mais claramente a missão de Cristo que a essência de sua pessoa. Contudo, não há oposição entre missão e essência da pessoa de Cristo. $\mathrm{Cl}$ 1,15, 2Cor 4,4 e Hb 1,3 se referem à Sb 7,26 ("É um reflexo da luz perene, um espelho sem mancha da atividade de Deus e uma imagem da sua bondade"). Tais expressões do Novo Testamento não tratam somente da função de Jesus Cristo, mas se referem à sua essência sempre em relação à sua função. Pode ser que o quadro cosmológico da "sabedoria" em Pv 8,22-31 e Sb 7,22-28 tenha influído em Cl 1,15ss. Mas as expressões paulinas deveriam ser interpretadas também em si mesmas e com base no seu significado próprio e dentro da teologia paulina ${ }^{21}$.

Fórmulas como "ser semelhante a Deus", "forma de Deus" (FI 2,6) ou ainda "irradiação de sua glória" e "imagem expressa de seu ser" (Hb 1,3) movem-se na direção dos vocativos e das interpretações de Cristo presentes no IV Evangelho. Mas, para qualificar a pessoa e a missão de Cristo, João escolheu um conceito predileto da filosofia grega o que nos leva a um claro testemunho do encontro do cristianismo com o helenismo. E o IV Evangelho conserva os traços deste encontro, não apenas no sentido positivo do reconhecimento de uma ligação entre o anúncio cristão e o helenismo, mas também no sentido restritivo de uma confutação dos influxos insanos do espírito helênico ${ }^{22}$.

Podemos admitir que o prólogo é dirigido primeiramente aos gregos. Mas é precisamente o conceito de Logos que supera a compreensão que os gregos fazem deste termo, pois a sua interpretação cristã é carregada de significação veterotestamentária e genuinamente cristã, de forma que 1,14 não deixa de ser um escândalo para os gregos.

O Logos joanino é ao mesmo tempo pessoal e transcendente. O Logos de Fílon é concebido como um ser, de um lado distinto de Deus, e por outro dotado de propriedades divinas e investido de uma função cosmológica-antropológica. Mas no prólogo joanino o Logos tem uma relação tanto com Deus quanto com o mundo e, em particular com a história que vai além do que previa Fílon, e que está na base da encarnação. Neste sentido, o Logos joanino é totalmente estranho a Filon ${ }^{23}$.

Jo 1,14 diz que Deus-Logos se fez carne e habitou entre nós homens. A presença do revelador em pessoa é uma presença na carne. A Palavra de Deus apareceu visivelmente (1Jo 1,1ss). O Logos de Deus é homem. O específico elemento joanino consiste na nitidez das antíteses e na profundidade da síntese

\footnotetext{
${ }^{21}$ GRILLMEIER, A. Op.cit., p.175s.

22 lbid., p.176.

${ }^{23}$ lbid., p.177.
} 
de Logos e sarx. Em nenhum outro livro do Novo Testamento a oposição entre e preexistência e vida na carne é delineada tão nitidamente como em João. Quanto mais divino e transcendente é o Logos, quanto mais supratemporal e supramundana a permanência junto de Deus, tanto mais resulta a sua presença numa autêntica natureza de carne ${ }^{24}$.

A expressão sarx (carne) tem a tarefa de pôr em evidência a visibilidade e realidade, mas também a mortalidade desta manifestação humana do Logos divino e imortal. Na cultura grega soa como estranho e até mesmo violento o contraste que há entre Logos e sarx, sobretudo quando ainda se relacionam as idéias de sua paixão e de sua morte. Por isto esta imagem cristã encontra tamanha oposição. Assim, a tentação grega será eliminar a realidade corpórea de Cristo ou dissolver a unidade do Logos e da sarx ${ }^{25}$.

Para contrastar com todas as tentações docetistas, João no IV Evangelho escolheu a expressão mais forte de "carne" do Logos com a qual ele entende seguramente a humanidade de Jesus na sua complexidade. Mas o termo por ele escolhido sublinha o elemento mais visível para situar a realidade da vinda do Deus-Logos no nosso mundo e para a nossa salvação. Que uma acentuação deste tipo poderia conduzir a uma perda de equilíbrio não estava nas intenções do IV Evangelho. Apesar de aguda, a síntese Logos-sarx não era desequilibrada. A história sucessiva deveria mostrar que esta tensão podia ser combinada tornando-se assim, complexamente, um fecundo impulso para a reflexão teológica no âmbito grego. No âmbito da compreensão posterior revelou-se que o IV Evangelho representa Jesus de Nazaré como homem íntegro dotado de corpo e alma, e também com sofrimentos espirituais e perturbações, ou seja, com uma autêntica vida humana. Isto significa que a idéia de Logos não ofuscou a imagem humana de Cristo ${ }^{26}$.

No séc. II, os apologistas lançavam mão da filosofia estóica para explicar a preexistência de Cristo, distinguindo a Palavra imanente (logos endiathetos) da Palavra expressa (logos prophorikos), como se vê, por exemplo, em Justino ${ }^{27}$.

Em Justino predomina a imagem do "outro Deus", do poder e sabedoria do Logos de Deus, imagem tomada do livro da Sabedoria, mas também da fase intermediária da filosofia do platonismo, que reúne em si as idéias que dão sentido e ordem ao mundo e que constituem a fonte mais profunda da compreensão

\footnotetext{
${ }^{24}$ Ibid., p.177s.

25 lbid., p.178.

26 lbid., p.178s.

${ }^{27}$ LACUGNA, C. M. O Mistério Trinitário de Deus., p.120.
} 
racional e a norma mais alta da moralidade humana ${ }^{28}$. Assim sendo, estão sob a ação do Logos tanto os santos do Antigo Testamento quanto os grandes sábios do paganismo. Destaforma, Justino afirma que não apenas a história da salvação, mas também a história da humanidade toda desemboca na encarnação do Filho de Deus ${ }^{29}$. Tal qual Irineu, Justino insiste no dado da encarnação para refutar tanto os docetas quanto os gnósticos ${ }^{30}$; tal senda será posteriormente percorrida, no século seguinte.

Os apologistas, partindo de premissas medioplatônicas (da "Média Academia" grega, dos seguidores de Platão), assumiram o esquema medioplatônico do real, que distinguia três planos, a saber: Deus, universo e homem. O elo intermediário que preenchia o abismo entre Deus e o universo era reconhecido no Logos, que foi identificado com Jesus, e que tinha uma função criadora cosmológica, ou seja, ele era o intermediário da criação. Aqui reside o risco de reduzir o Cristo ao nível de um "deus menor", apesar do empenho de Justino em afirmar que o Logos é distinto, mas não separado do $\mathrm{Pai}^{31}$.

$\mathrm{Na}$ teologia do Logos do séc. II já estão presentes os pressupostos da confissão no único Cristo, Deus e homem. No século seguinte já era manifesta a divindade do Logos preexistente e, ao mesmo tempo a real encarnação no seio de Maria, bem como a unidade da divindade e da humanidade ${ }^{32}$.

No séc. III, especialmente nos escritos de Tertuliano, e de Orígenes ${ }^{33}$, dáse a elaboração de um vocabulário técnico, de corte metafísico (hypostasis, subsistentia, ousia, natura), com o qual se quer expressar a fé em Cristo e a relação entre a sua humanidade e a sua divindade ${ }^{34}$.

Tertuliano e Hipólito desenvolveram as idéias de Justino e de seu contemporâneo Irineu de Lion: Jesus é a Palavra que procede de Deus, que tem poder criador, e se torna homem em Jesus Cristo, sendo que o divino e o humano são o mesmo $\operatorname{Logos}^{35}$. Tertuliano vai mais além, distinguindo em Cristo duas "substâncias", a divina (chamada espiritual) e a corporal ${ }^{36}$.

\footnotetext{
28 SMULDERS, P.Evolução da Cristologia na História dos Dogmas e no Magistério Eclesiástico., p.19.

29 lbid., p.19.

30 lbid., p.26.

${ }^{31}$ PADOVESE, L. Introdução à Teologia Patrísca., p.49s.

32 STUDER, B. Dios Salvador en los Padres de La Iglesia., p.290s.

${ }^{33} \mathrm{Cf}$. infra.

${ }^{34}$ LACUGNA, C.M. O Mistério Trinitário de Deus., p.221.

${ }^{35}$ SMULDERS, P.Op.cit., p.26.

${ }^{36}$ TERTULIANO. De Carne Christi 1, 2 Apud SMULDERS, P.Op.cit., p.27.
} 


\section{4 Cristologia de Justino}

O conceito que Justino tem de Deus manifesta sua forte inclinação para a filosofia platônica. Deus não tem princípio, por issoé inefável e sem nome. O nome que melhor o qualifica é o de Pai. Sendo Criador é realmente o Pai de todas as coisas. Justino nega a onipresença substancial de Deus. Deus Pai vive, segundo ele, em regiões situadas acima do céu. Não pode abandonar sua morada, e consequentemente não pode aparecer no mundo. "Nada, absolutamente, por pouca inteligência que tenha, se atreverá a dizer que foi o Criador e Pai do universo quem, deixando todas as suas moradas supra celestes, apareceu em uma mínima porção de terra" ${ }^{37}$.

(...) Porque o Pai inefável e Senhor de todas as coisas não chega a nenhuma parte, não passeia, não dorme, nem se levanta, mas permanece sempre em sua própria região, onde quer que ela seja, olhando com penetrante olhar, olhando agudamente, mas não com olhos, nem orelhas, mas por uma potência inefável. Tudo observa e tudo conhece, e nada de nós Ihe está oculto, sem precisar mover-se, Ele que não cabe em nenhum lugar, nem no mundo inteiro e era antes que o mundo existisse ${ }^{38}$.

Mas como Deus é transcendente e está acima de todo ser humano, é necessário salvaguardar o abismo que há entre Deus e o homem. E esta foi precisamente a obra do Logos. Ele é o mediador entre Deus Pai e o mundo. Deus não se comunica com o mundo e não se revela a ele senão através do Logos. $O$ Logos é o guia que conduz Deus aos homens sendo ainda o mestre destes. No princípio o Logos morava em Deus como uma potência. Mas pouco antes da criação do mundo emanou e procedeu Dele, e assim o mundo foi criado pelo Logos. Em seu Diálogo, Justino se vale das imagens para explicar a geração do Logos.

Algo semelhante vemos também em um fogo que se ascende de outro, sem que se diminua aquele do qual se tomou a chama, mas permanecendo o mesmo. E o fogo ascendido também aparece com seu próprio ser, sem haver diminuído aquele de onde se ascendeu ${ }^{39}$.

Justino parece inclinar-se ao subordinacionismo no que diz respeito às relações entre o Pai e o Logos. Prova clara disto temos na Apologia.

Seu Filho, aquele que só propriamente se diz Filho, o Verbo, que está com Ele antes das criaturas e é gerado quando no princípio criou e ordenou por seu intermédio

\footnotetext{
37 JUSTINO. Dialogus cum Tryphonel. 60, 2.

${ }^{38} \mathrm{Ibid} ., 127,2-3$.

39 lbid., 61, 2.
} 
todas as coisas, se chama Cristo por sua unção e por haver Deus ordenado através Dele todas as coisas ${ }^{40}$.

Consequentemente, Justino supõe, ao que parece, que o Verbo se fez externamente independente somente com a finalidade de criar e governar $o$ mundo. Sua função pessoal concedeu-Ihe sua existência pessoal. É pessoa divina, porém subordinada ao $\mathrm{Pai}^{41}$.

A doutrina mais importante de Justino é a doutrina do Logos, que forma uma espécie de ponte entre a filosofia helênica e o cristianismo. Com efeito, Justino ensina que embora o Logos divino não tenha aparecido em sua plenitude mais que em Cristo, uma semente do Logos estava já presente em toda a humanidade muito antes de Cristo. Pois todo ser humano possui em sua razão uma semente

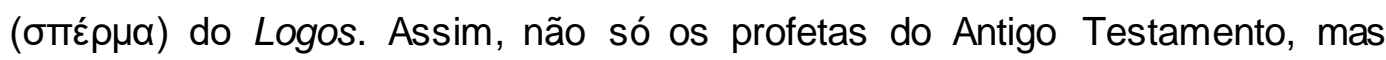
também os filósofos pagãos traziam em suas almas uma semente do Logos em via de germinar. Justino cita ainda os exemplos de Heráclito, Sócrates e o filósofo estóico Musônio, que viveram segundo normas do Logos, o Verbo Divino. Estes pensadores foram, na verdade, verdadeiros cristãos.

Nós aprendemos que Cristo é o primogênito de Deus, e anteriormente aprendemos que Ele é o Verbo, do qual todo o gênero humano participa. E assim, os que viveram conforme o Verbo, são cristãos, ainda que tenham sido considerados ateus, como sucedeu entre os gregos Sócrates e Heráclito e outros semelhantes ${ }^{42}$.

Neste sentido, não há oposição entre cristianismo e filosofia ${ }^{43}$. Para Justino a existência de elementos de verdade na filosofia pagã consiste em prova histórica de que os filósofos pagãos disseram muitas verdades, se apropriando inclusive da literatura dos judeus do Antigo Testamento ${ }^{44}$. Porém, somente os cristãos possuem a verdade em plenitude, porque Cristo se revelou como a Verdade em pessoa.

\section{5}

\section{Cristologia de Irineu}

A teologia do Logos de Irineu também merece especial atenção, visto que, se Justino é o apologista grego mais importante do século II, Irineu é o teólogo latino mais importante do mesmo século.

Sobre a relação do Filho com o Pai, Irineu diz:

\footnotetext{
40 JUSTINO. Apol. II, 6.

${ }^{41}$ Id. Diál. 61.

42 Id. Apol. I 46,2-3.

43 Ibid., II 10,2-8.

44 Ibid., I 44, 8-10.
} 
Por isso, se alguém nos perguntar: Como foi gerado o Filho pelo Pai? Responderemos que esta emissão ou geração ou enunciação ou manifestação ou seja qual for o nome com que se queira chamar esta geração inefável, ninguém a conhece, nem Valentim, nem Marcião, nem Saturnino, nem Basílides, nem os anjos, nem os Arcanjos, nem os Principados, nem as Potestades, mas somente o Pai que gerou e o Filho que foi gerado. Sendo, portanto, a sua geração inefável, todos os que tentam explicar as gerações e emissões não sabem o que dizem e prometem expor coisas indizíveis ${ }^{45}$.

Todavia, temos em Irineu a primeira tentativa de compreender a relação entre o Pai e o Filho de uma maneira especulativa: "Assim, por meio do Filho que está no Pai e que tem em si o Pai, manifestou-se o Deus que é, o Pai dando testemunho ao Filho e o Filho anunciando o Pai" ${ }^{46}$.

Desta maneira Irineu combate os gnósticos e defende a identidade do Pai como o criador do mundo. $E$ ainda afirma que há um só Cristo, mesmo que o conheçamos por diferentes nomes. Neste sentido, o Cristo é identificado como o Filho de Deus, o Logos, o Homem-Deus Jesus, o nosso Salvador e Senhor.

Devemos ainda afirmar que o ponto central de toda a cristologia de Irineu está na teoria da recapitulação, que por sua vez possui sua gênesis em São Paulo. Contudo, foi o Bispo de Lion quem a desenvolveu consideravelmente. Para Irineu, recapitulação é resumir todas as coisas no Cristo desde o principio dos tempos. Deus refaz seu plano de salvar a humanidade, que havia sido prejudicado pela queda de Adão, mas que é retomado desde o princípio a fim de renovar, restaurar e reorganizar toda a criação em seu Filho encarnado, que a partir daí se converte para nós em segundo Adão. Pois visto que com a queda do primeiro homem toda a natureza humana se viu decaída, foi preciso que o Filho de Deus se fizesse homem para realizar como tal uma nova criação da humanidade.

\begin{abstract}
Se o Senhor se tivesse encarnado por conta de outra economia e se tivesse assumido carne de outra substância não teria recapitulado em si o homem e até nem poderia ser chamado carne, porque somente seria carne se derivasse daquela obra primitiva modelada do limo da terra. Se o Senhor tivesse que assumir a carne tirada de outra substância, já desde o princípio o Pai usaria essa substância para modelar a sua obra. Contudo, o Verbo salvador se tornou aquilo mesmo que era o homem que se perdeu para salvá-lo, operando assim em si mesmo a comunhão com o homem e a sua salvação. $O$ que se perdera tinha carne e sangue, porque foi usando o limo da terra com que Deus plasmou o homem e era justamente por este homem que se devia realizar a economia da vinda do Senhor ${ }^{47}$.
\end{abstract}

Com esta recapitulação do homem original, não somente foi renovado o primeiro Adão pessoalmente, mas também toda a humanidade:

\footnotetext{
45 IRINEU. Adv. Haer. 2, 28,6.

46 Ibid., 3, 6,2.

47 lbid., 5, 14,2.
} 
(...) mas quando se encarnou e se fez homem, recaptulou em si toda a longa série dos homens, dando-nos em resumo a salvação, de forma que o tínhamos perdido em Adão, isto é, a imagem e semelhança de Deus, o recuperássemos em Jesus Cristo ${ }^{48}$.

Foi destruído o fruto da desobediência de Adão: "Deus que recapitulava em si a modelagem antiga, o homem, para destruir o pecado, abolir a morte e vivificar o homem; por isso, a sua obra é veraz" ${ }^{49}$. Assim o segundo Adão, o Filho de Deus humanado retomou a antiga contenda com o diabo e a venceu.

O Senhor não teria recapitulado em si a antiga e primeira inimizade contra a serpente e não teria cumprido a promessa do Criador e nem o seu mandamento se tivesse vindo de outro pai. Mas, sendo um só e idêntico aquele que, no princípio, nos modelou e, no fim, enviou seu Filho, o Senhor cumpriu verdadeiramente o seu mandamento nascendo de mulher, aniquilando o nosso adversário e completando no homem a imagem e semelhança de Deus ${ }^{50}$.

Cristo o renovou em toda a sua plenitude com esta recapitulação. “(...) então o que trouxe de novidade a vinda do Senhor? Ficai sabendo que trouxe toda novidade, trazendo a si mesmo, que fora anunciado. Com efeito, o que foi predito é que a novidade viria para renovar e vivificar o homem" 51 .

\section{6 \\ Cristologia Adopcionista}

O adopcionismo é tradicionalmente considerado uma heresia de tipo judaico e relacionada com o ebionismo. Pois, como os judeus, os adopcionistas não reconheciam a divindade de Cristo e o reduziam à simples homem. Esta postura está presente no pensamento de Cerinto e Carpócrates. Cerinto é apresentado por Irineu como um gnóstico que afirmava que o mundo não havia sido criado por Deus, mas por uma força interior, que Jesus era filho de José e Maria com uma geração comum, porém, mais justo que os demais homens. A partir do batismo no Jordão, quando então o Espírito Divino desceem forma de pomba, ele começa a anunciar o Pai e a operar prodígios.

Cerinto, asiático, ensina que o mundo não foi feito pelo primeiro Deus, mas por uma potência distinta e bem afastada da Potência que está acima de todas as coisas, que não conhecia o Deus que está acima de tudo. Jesus, segundo Cerinto, não nasceu da Virgem, porque isto lhe parecia impossível, mas foi filho de José e de Maria de maneira semelhante à dos outros homens e sobressaiu entre todos pela santidade, prudência e sabedoria. Depois do batismo desceu sobre ele, daquela Potência que está acima de todas as coisas, o Cristo, na forma de pomba, desde então começou a anunciar o Pai incógnito e a fazer milagres. Finalmente o Cristo

\footnotetext{
48 Ibid., 3, 18,1.

49 lbid., 3,18,7.

50 lbid., 5, 21,2.

51 lbid., 4, 34,1.
} 
saiu de Jesus, voltou para o alto e Jesus sofreu e ressuscitou, enquanto o Cristo permanecia impassível, porque era pneumático ${ }^{52}$.

Carpócrates é também apresentado por Irineu como possuidor de uma concepção similar a de Cerinto a cerca do Senhor.

\begin{abstract}
Carpócrates e os seus discípulos dizem que o mundo e as coisas nele contidas foram feitas por Anjos muito inferiores ao Pai ingênito. Jesus, que nasceu de José semelhante a todos os homens, distinguiu-se deles porque a sua alma forte e pura se lembrava do que tinha visto na esfera do Pai ingênito. Por isso foi-the dada pelo Pai a força que lhe permitiu escapar aos criadores do mundo e assim, passando por todos completamente livre, subiu junto a ele. E o mesmo se dá com os que têm disposições semelhantes. Dizem que a alma de Jesus, educada nos costumes dos judeus, os desprezava e por isso recebeu o poder de destruir nos homens as paixões que lhes foram impostas como castigo ${ }^{53}$.
\end{abstract}

Os adopcionistas procuravam fundamentar sua doutrina em passagens das Sagradas Escrituras, das quais se podia deduzir que Jesus era apenas um simples homem ${ }^{54}$.

Segundo Eusébio o pai e cabeça desta apostasia que negava Deus, sendo o primeiro a dizer que Cristo era um simples homem, foi um certo Teódoto de Bizâncio, chamado "o Curtidor", que difundiu esta doutrina em Roma no final do século II. Contudo, foi excluído da comunidade nos anos 190 no pontificado de Vítor ${ }^{55}$, mas ainda deixando discípulos que continuaram a difundir sua doutrina, principalmente um aluno seu também chamado Teódoto e também de Bizâncio, mas apelidado de "o Banqueiro" e por Artemão entre os anos 230 e 250. Todavia, formas mais evoluídas de adopcionismo foram ainda propostas aproximadamente entre 260-270 por Paulo de Samósata, que pôde contar com a adesão de Nestório, e por Fotino de Sírmio (meados do século IV) ${ }^{56}$.

\title{
2.7 \\ Cristologia do Logos de Hipólito
}

Hipólito, contra o monarquismo de Noeto, desenvolve sua cristologia segundo a qual o Logos é gerado em ordem a criação do mundo.

Qual o autor, conselheiro e realizador de tudo que foi criado, gerou o Logos e este Logos, ele tinha em si e que era invisível, ele o torna visível ao mundo criado. Enunciando-o primeiro como voz e gerando-o luz da luz, emite como Senhor para a criação sua própria inteligência, e esta, que era inicialmente visível somente a ele e

\footnotetext{
52 lbid., I, 26,1.

53 lbid., I, 25,1.

${ }^{54}$ SIMONETTI, M. Adocionistas., p.43.

${ }^{55}$ EUSÉBIO. Hist. Ecl. V, 28,6

56 SIMONETTI, M. Op.cit.
} 
invisível ao mundo criado, torna-a visível, a fim de que o mundo, vendo-a passe ser salvo graças a tal epifania ${ }^{57}$.

Hipólito define a relação entre o Logos e o Pai em termos subordinacionistas, na mesma linha dos apologistas Justino, Atenágoras, Teófilo e Tertuliano. Contudo, o seu subordinacionismo é ainda mais acentuado. Ele não somente distingue entre o Verbo imanente em Deus (logos endiathetos) e o Verbo proferido por Deus (logos prophorikos), mas descreve a geração do Verbo como um desenvolvimento progressivo em três fases: a fase que precede a criação, a fase que segue após a criação e a encarnação. Assim, Hipólito foi mais longe que os apologistas, associando a geração do Logos não somente a criação do mundo, mas também a encarnação. Na verdade ele não se deu conta de que esta evolução do Verbo em fases distintas introduzirá na essência divina um certo crescimento. Contudo, o progresso é incompatível com a imutabilidade divina. Hipólito cometia outro erro ao fazer da geração do Verbo um ato livre como o da criação e ao sustentar que Deus precisamente por querer agir assim, poderia fazer de um homem Deus ${ }^{58}$.

\section{8 \\ Cristologia do Logos de Tertuliano}

Tertuliano é o primeiro dos Padres Latinos e um dos maiores autores cristãos dos séculos II e III. O epíteto Vir ardens a ele atribuído por São Jerônimo revela sua personalidade e temperamento ardente e combativo, mas ao mesmo tempo generoso e apostólico.

Dentre as suas principais contribuições para a teologia podemos destacar a sua doutrina acerca da Trindade e da Cristologia. Algumas de suas fórmulas e definições são tão precisas e tão acertadas que passaram para a terminologia eclesiástica até nossos dias. Como é o caso do próprio termo Trindade ou Trinitas, que por ele nos é transmitido, dado o fato de estar ele entre os primeiros autores que expressam todo um conjunto de idéias cristãs em latim, ao se apoiar nas traduções já existentes da Bîblia. Na verdade ele foi o primeiro a aplicar o termo latino Trinitas às três pessoas divinas. Em De pudicitia 21 Tertuliano fala de uma Trinitas unius Divinitatis, Pater et Filius et Spiritus Sanctus.

Todavia, é em Adversus Praxean que podemos encontrar a expressão mais perfeita a respeito da Trindade. Aí Tertuliano explica a compatibilidade entre

\footnotetext{
57 HIPÓLITO. Contra Noeto 10, 4; BP. 35, 172.

58 ld. Philos. 10,33,7; QUASTEN, J. Patrologia., pp 487-488.
} 
a unidade e a trindade ao recorrer à unicidade dos três em sua substância e em sua origem: "tres unius substantiae et unius status et unius potestatis" 59. O Filho é da substância do Pai: "De Filium non aliunde deduco, sed de substantia Patris"'60. O Espírito é do Pai pelo Filho: "Spiritum non aliunde deduco quam a Patre per

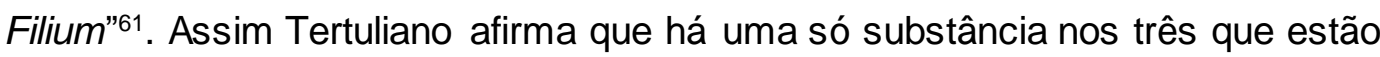
unidos entre si: "Ubique teneo unam substantiam in coherentibus"62. No capítulo 25 de Adversus Praxean ele explica a relação existente entre o Pai, o Filho e o Espírito Santo da seguinte maneira: "Conexus Patris in Filio et Filii in Paraclito tres efficit coherentes, alterum e altero. Qui tres unum sunt, non unus". Tertuliano foi ainda o primeiro a empregar o termo persona, que haveria de se tornar tão famoso na história da teologia posterior.

Tertuliano declara ainda que o Logos é um alter em relação ao Pai, ou seja, no sentido de persona, não de substância. De modo que há uma clara distinção entre Eles, mas não divisão: "alium autem quomodo accipere debeas iam professus sum, personae non substantiae nomine, ad distinctionem nom ad divisionem"63. O vocábulo persona é também aplicado ao Espírito Santo, a quem Tertuliano chama de terceira pessoa.

Contudo, Tertuliano não conseguiu se livrar da influência do subordinacionismo. A antiga distinção entre o Logos endiathetos e o Logos prophorikos, o Verbo interno ou imanente em Deus e o Verbo emitido ou proferido por Deus, que desviou os apologistas gregos da sã doutrina, também induz Tertuliano a pensar que a geração divina se efetua gradualmente. Embora Sabedoria e Verbo sejam nomes idênticos para a segunda Pessoa da Trindade, Tertuliano distingue entre o primeiro nascimento enquanto Sabedoria antes da criação, e uma nativitas perfecta no momento da criação quando o Logos foi proferido e a Sabedoria vem a ser o Verbo:

Foi então quando o Verbo recebeu sua manifestação e seu complemento, ou seja, o som e a voz, quando Deus disse: "Faça-se a luz". Este é o nascimento perfeito do Verbo quando procedeu de Deus. Primeiro foi produzido por Ele no pensamento sob o nome de Sabedoria: "Deus me criou no princípio, como primícia de suas obras" ( $\operatorname{Pr} 8,22)$. Logo foi gerado em vista da ação: "Quando Ele preparava os céus, ali estava eu" (Pr 8,27). Assim, fazendo que fosse seu Pai Aquele de quem era Filho por proceder dele, vindo a ser o primogênito, porque foi gerado antes de todas as coisas, e Filho único, porque somente Ele foi gerado por Deus ${ }^{64}$.

\footnotetext{
59 TERTULIANO. Ad. Prax., 2.

$60 \mathrm{lbid}$.

61 lbid.

62 lbid., 12.

$63 \mathrm{lbid}$.

64 lb. 7 .
} 
Nesta linha de pensamento o Filho não é eterno65. Ainda que o Logos seja res et persona antes da criação do mundo per substantiae proprie atem ${ }^{66}$. O Pai é todo substância (tota substantia est), enquanto o Filho é uma emanação e porção do todo (derivatio totius et portio), como Ele mesmo confessa, porque o Pai é maior do que eu (Jo 14,28). As analogias que Tertuliano emprega para explicar a divindade explicitam suas tendências subordinacionistas, mais precisamente quando diz que o Filho provém do Pai como o raio de luz provém do Sol ${ }^{67}$.

A despeito de suas claras tendências subordinacionistas, a doutrina trinitária de Tertuliano representa um passo adiante de considerável importância. Algumas de suas fórmulas são idênticas as do Concílio de Nicea, celebrado mais de cem anos depois. Outras foram adotadas pela tradição e pelos concílios posteriores. O mesmo deve-se dizer de maneira muito particular acerca de sua cristologia, que possui todos os méritos de sua doutrina trinitária e nenhum de seus deméritos ou deficiências. Tertuliano afirma claramente as duas naturezas na única pessoa de Cristo. Não há transformação da divindade na humanidade; muito menos uma fusão ou mistura que haveria feito das duas uma única substância.

\begin{abstract}
Percebemos claramente a dupla condição que não se confunde, mas que se une em uma só pessoa: Jesus, Deus e homem (...). Assim, a propriedade de uma e outra natureza permanece também sem confusão, de modo que por um lado o Espírito realiza as obras que Ihes são próprias em Jesus, como os milagres, os atos de poder e os prodígios; por outro lado, a carne manifesta as afeições que the são próprias; teve fome ante a tentação do demônio, sede com a samaritana, chorou sobre Lázaro, esteve triste até a morte e, por fim foi morto. Mas se fosse um terceiro ser, fruto da mescla das duas naturezas, algo como que electrum, neste caso não apareceria provas tão distintas por cada uma das duas substâncias. Por uma transmissão de poderes, o Espírito faria as obras da carne e a carne as do Espírito, ou realizariam obras que não corresponderiam nem a carne nem ao Espírito, mas atos próprios da terceira espécie, fruto desta mescla. Suposto isto, há que se dizer que ou o Verbo morreu ou a carne não morreu, se o Verbo tivesse se tornado carne, pois neste caso, a carne seria imortal, e o Verbo mortal. Porém, como as duas substâncias trabalham distintamente, cada uma segundo seu próprio caráter, então suas ações e seus efeitos se processarão também de modo distinto ${ }^{68}$.
\end{abstract}

Com tais palavras podemos já aqui perceber e reconhecer a fórmula do futuro Concílio de Calcedônia, que trata das duas substâncias em uma só pessoa.

\footnotetext{
${ }^{65}$ TERTULIANO. Adv. Hermogenem 3.

66 lbid.

67 lbid., 8.

68 lbid., 27.
} 


\section{9 \\ Cristologia de Orígenes}

Após S. Irineu, é em Orígenes que encontramos uma síntese significativa da Teologia Cristã ${ }^{69}$, tendo apresentado as bases para os debates teológicos e cristológicos posteriores.

Ao serem abordadas as obras e a teologia de Orígenes, deve-se considerar que a teologia cristã não estava ainda suficientemente amadurecida, sobretudo com relação à precisão de diversos termos teológicos. Mas é mérito de Orígenes ter enriquecido a teologia grega, sobretudo a cristologia, com os termos physis, hypostasis, ousia, homoousios, theanthropos ${ }^{70}$.

Orígenes usa com frequência o termo trias, trindade ${ }^{71}$. Para ele o Pai é ser absoluto e incompreensível, mas que se faz compreensível por meio do Logos, que é Cristo ${ }^{72}$. Mas que também é o Filho que procede do Pai, não por um processo de divisão, mas da mesma maneira que a vontade procede da razão, ou seja, por um ato espiritual:

Se o Filho faz tudo o que faz o Pai, por conseguinte o Filho faz tudo como o Pai, a
imagem do Pai se manifesta no Filho, que dele nasceu por um ato da vontade que
procede da inteligência. E por este motivo creio que a vontade do Pai deve ser
suficiente para fazer que exista o que Ele quer que exista. Porque, ao querer, não
faz outra coisa que proferir a decisão de sua vontade. E assim é engendrada por
ele a existência (subsistentia) do Filho. Isto deve mantê-lo acima daqueles que não
admitem que exista nenhum ser ingênito, isto é, não nascido, a exceção de Deus
Pai... Assim como o ato da vontade procede da inteligência, sem que por isto fique
alguma parte nem se separe ou divida dela, deve-se supor que de maneira análoga
o Pai gerou o Filho, sua própria imagem que é invisível. O Filho é o Verbo. Por
conseguinte, não devemos pensar que haja nEle nada que possa ser percebido
pelos sentidos. É sabedoria, e na sabedoria não cabe nada corpóreo. É a luz
verdadeira que ilumina todo homem que vem a este mundo; porém não tem nada
em comum com a luz de nosso sol. Nosso Salvador expôs a imagem de Deus Pai
invisível. Com relação ao Pai, é a verdade; com relação conosco, é quem nos revela
o Pai, é a imagem que nos leva ao conhecimento que nos leva ao Pai, de quem
ninguém conhece, exceto o Filho e aquele a quem o Filho quiser revelar ${ }^{73}$.

Para Orígenes, em Deus tudo é eterno, inclusive o ato de geração do Filho: "aeterna ac sempiterna generatio"74. Pela mesma razão o Filho não tem princípio, e, portanto, não teve um tempo em que ele não existisse ${ }^{75}$. Esta noção de geração eterna, tendo o Pai como princípio, como "fonte da divindade"76 evita o triteísmo,

${ }^{69}$ CARDEDAL, O. G. Cristologia., p.220.

${ }^{70}$ QUASTEN, J. Patrologia., p.392.

71 ORÍGENES. In loh. 6, 33; 10,39 Apud QUASTEN, J. Op.cit., p.375.

72 Id. De principii 1,2,8; Id. Contra Celso 7,17 Apud QUASTEN, J. Op.cit., p.374.

${ }^{73}$ Id. De Principii 1,2,6 Apud QUASTEN, J. Op.cit., pp.375s.

${ }^{74}$ Id. In ler. 9,4; Id. De principii 1,2,4 Apud QUASTEN, J. Op.cit., p.376.

${ }^{75}$ Id. De principii 1,2,9; 4,4,1; Id. In Rom. 1, 5 Apud QUASTEN, J. Op.cit., p.376.

76 Id. In loh. 2,3. 
mas não o subordinacionismo ${ }^{77}$.

Orígenes afirma que a geração do Filho não é por adoção, mas Pai e Filho possuem unidade de substância. Foi Orígenes que cunhou a palavra homoousios, consubstancial, que se tornou famosa nas controvérsias cristológicas e no Concílio de Nicéia, em 325. Foi Orígenes quem pela primeira vez atribuiu o termo homoousios a cada uma das pessoas divinas:

\begin{abstract}
Que outra coisa podemos supor que é a luz eterna senão Deus Pai, de quem nunca se pode dizer que, sendo luz seu Esplendor $(\mathrm{Hb}$ 1,3) não estivera presente com Ele? Não se pode conceber luz sem resplendor. E se isto é verdade, nunca existiu um tempo que o Filho não fosse Filho. Sem dúvida, não será, como dissemos da luz eterna, sem nascimento pareceria que introduzimos dois princípios de luz, mas que é, por assim dizer, resplendor da luz ingênita, tendo esta mesma luz como princípio e como fonte, verdadeiramente nascido dela. Não obstante, não houve um tempo em que ele não foi. A sabedoria, por proceder de Deus, é gerada da mesma substância divina. Sob a imagem de uma emanação corporal, assim é chamada "Emanação pura da glória de Deus onipotente" (Sb 7,25). Estas duas comparações manifestam claramente a comunhão de substâncias entre o Pai e o Filho. Com efeito toda emanação parece ser consubstancial, ou seja, de uma mesma substância com o corpo do qual emana ou procede ${ }^{78}$.
\end{abstract}

Orígenes apresenta Pai e Filho e Espírito Santo hipostaticamente distintos desde toda a eternidade, graças a suas relações e missões; isto implica a ideia de Trindade atemporal; foi também quem primeiro apresentou o Espírito Santo como pessoa não criada ${ }^{79}$.

Como exemplo do emprego impreciso do termo homoousios, pode-se recordar Paulo de Samósata, que foi eleito bispo de Antioquia em 260, e que usou o termo homoousios de Orígenes de forma adocionista, ou seja, que Jesus era mero homem e o Logos fez nele morada; por este motivo o termo homoousios foi rechaçado num sínodo em Antioquia em 268, por ser inadequado para expressar a relação entre o Pai e o Filho ${ }^{80}$. Esta condenação de 268 fez com que o Credo de Nicéia não fosse plenamente acolhido após a sua celebração ${ }^{81}$, como se verá adiante.

A Teologia do Logos de Orígenes representa um avanço considerável, em que é possível distinguir duas linhas de pensamento. Uma realça a divindade do Logos, enquanto a outra o chama de "um segundo Deus", deutero theós ${ }^{82}$. Somente o Pai é autotheós e aplos agathós, a bondade original. O Filho é a imagem da bondade, eikon agathotetos ${ }^{83}$.

\footnotetext{
77 GOMES, C. F. A doutrina da Trindade Eterna., p.253.

78 ORÍGENES. Contra Celso 8, 12; Id. In Ioh. 2, 10, 75 Apud GOMES. C. F. Op.cit., p.252.

79 SCHEFFCZYK, L. Formulação Magisterial e História do Dogma da Trindade., p.153.

${ }^{80}$ CARDEDAL, O.G. Cristologia., p.233.

81 MARROU, H.; DANIELOU, J. Nova História da Igreja., p.264.

${ }^{2}$ ORÍGENES. Contra Celso 5,39; Id. In loh. 6,39 Apud QUASTEN, J. Patrologia., p.377.

83 Id. Contra Celso 5, 39; Id. De Principiis 1,2,13 Apud QUASTEN, J. Op.cit.
} 
A união das duas naturezas em Cristo é extremamente estreita, "porque a alma e o corpo de Jesus formaram depois da oikonomia, ou seja, depois da encarnação, um só ser com o Logos de Deus"84. Orígenes ensina a communicatio idiomatum, ou a troca de atributos. Ainda designando Cristo com um nome que denota sua divindade, podem-se atribuir a Ele predicados humanos e vice-versa.

Ao Filho de Deus, por quem foram criadas todas as coisas, é chamado Jesus Cristo e Filho do Homem. Pois também se diz que o Filho de Deus morreu - precisamente por causa daquela natureza que poderia parecer morte. Leva o nome de Filho do homem, de quem se anuncia que virá na glória de Deus Pai com os santos anjos. Por isto, através de toda a Escritura, à natureza divina se aplicam atributos humanos, e se distingue a natureza humana com títulos que correspondem à dignidade divina ${ }^{85}$.

O Filho e o Espírito Santo são para Orígenes os intermediários entre o Pai e as criaturas:

\begin{abstract}
Nós que cremos no Salvador quando diz 'O Pai, que me enviou, é maior que eu', e por esta mesma razão não permite que se aplique o atributo de 'bom' em sentido pleno, verdadeiro e perfeito, mas que o atribui ao Pai dando graças e condenando o que glorifica o Filho em demasia, nós dizemos que o Salvador e o Espírito Santo estão bem acima de todas as criaturas, com uma superioridade absoluta, sem par; porém dizemos que o Pai está acima deles tanto ou mais quanto eles estão acima das criaturas mais perfeitas ${ }^{86}$.
\end{abstract}

Orígenes supõe uma ordem hierárquica na Trindade, que coloca o Espírito Santo em um plano inferior ao do Filho ${ }^{87}$. O Espírito Santo é "o mais sublime dos seres vindos à existência através do Verbo, o principal dentre os que se originaram do Pai através de Cristo" 88 .

Com esta noção de hierarquia, provavelmente de origem neoplatônica ${ }^{89}$, Orígenes, de alguma forma, compromete a sua teologia, pois põe em perigo a igualdade e a consubstancialidade das pessoas divinas ${ }^{90}$.

Por estas e outras passagens similares se compreende por que motivo Orígenes foi acusado de subordinacionismo. S. Jerônimo $(+419)$ acusava Orígenes de subordinacionista. S. Gregório Taumaturgo (+270), discípulo próximo de Orígenes, e S. Atanásio (+273) o consideram acima de qualquer suspeita ${ }^{91}$. Autores modernos, como Regnon e Prat ${ }^{92}$, bem como o grande patrólogo $\mathrm{B}$.

\footnotetext{
84 ORÍGENES. Contra Celso 2,9 Apud QUASTEN, J. Op.cit., p.379.

85 Id. De Principii 2,6,3 Apud QUASTEN, J. Op.cit.

86 Id. In loh. 13,25 Apud QUASTEN, J. Op.cit., p.377.

87 Id. De Principii, Praef. 4 Apud QUASTEN, J. Op.cit.

88 Id. In Ioh. 2,10; cit. GOMES, C.F. Op.cit., p.253.

${ }^{89}$ SCHEFFCZYK. Op.cit., p.153.

90 FRANGIOTTI, R. História das Heresias., p.60.

${ }^{91}$ QUASTEN, J. Patrologia., p.377.

$92 \mathrm{lbid}$.
} 
Altaner o têm como subordinacionista ${ }^{93}$. O teólogo espanhol O. C. de Cardedal afirma a possibilidade de uma leitura ortodoxa dos escritos de Orígenes, apesar dos traços subordinacionistas dos mesmos ${ }^{94}$. Para Orígenes o Ser divino é um dinamismo de comunicação que tem por raiz a vontade, o thélema do Pai, mas isto não compromete a consubstancialidade das pessoas divinas ${ }^{95}$.

Diferentemente dos apologistas, que possuíam um esquema tripartite Deus-cosmo-homem eatribuíam ao Logos uma função cosmológica intermediária, Orígenes dá um passo adiante, procurando a relação entre transcendência e imanência, ou entre a divindade e a humanidade no Cristo, precisamente na sua alma, na união entre esta e o Logos desde a preexistência, mais que união moral96.

Orígenes relaciona sua doutrina do Logos com a doutrina de Jesus encarnado presente nos Evangelhos. Introduz o conceito de alma de Jesus e vê nesta alma preexistente o elo entre o Logos infinito e o corpo finito de Cristo.

\begin{abstract}
Sendo esta substância da alma intermediária entre Deus e a carne, pois é impossível que a natureza de Deus se misture com um corpo sem que haja um

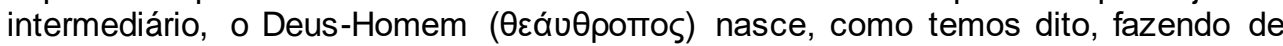
intermediária esta substância, cuja natureza não rejeita assumir um corpo. Por outro lado, muito menos era contrário a natureza desta alma, como substância racional que era, receber a Deus, em quem havia entrado já totalmente, segundo dissemos acima, assim como no Verbo, na Sabedoria e na Verdade. Ela, pois, merece também, juntamente com a carne que assumiu, os nomes de Filho de Deus, Poder de Deus, Cristo e Sabedoria de Deus, enquanto que estava inteiramente no Filho de Deus ou havia recebido inteiramente dentro de si o Filho de Deus. ${ }^{97}$
\end{abstract}

Orígenes é também o primeiro a usar a expressão Deus-Homem,

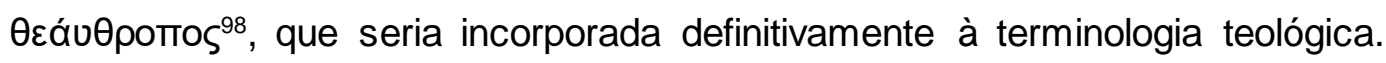
Acerca da Encarnação afirma que a carne na qual penetrou esta alma de Cristo era "ex incontaminata virgine assumpta et casta sancti spiritus operatione formata"99. Por sua união com o Logos, a alma de Cristo não podia pecar.

\footnotetext{
Não se pode por em dúvida que sua alma fora da mesma natureza que a dos demais. Se não fosse de verdade, não se poderia chamar de alma. Mas, ao corresponder a todas as almas o poder de escolha entre o bem e o mal, a de Cristo escolheu o amor à justiça, de modo que com toda a imensidade de seu amor aderiu a ela irrevogavelmente e sem separação possível, de maneira que a firmeza de sua intenção, a imensidade de seu afeto e o ardor inextinguível de seu amor anularam toda possibilidade de retroceder e mudar. $O$ que anteriormente dependia da vontade, foi trocado a partir daí de natureza para força de um grande hábito.

${ }^{93}$ ALTANER, B.; STUIBER, A. Patrologia., p.212.

${ }^{94}$ CARDEDAL, O. G. Cristologia., p.222.

${ }_{95}$ ARDANAZ, F. El problema del dinam ismo trinitario en Origenes., pp.67-98 Apud GOMES, C.F. A doutrina da Trindade Eterna., p.254.

96 PADOVESE, L. Introdução à teologia Patrística., p.52s.

97 ORÍGENES. De principiis 2,6,3 Apud QUASTEN, J. Patrologia., p.378.

98 Id. In Ez. Hom 3,3.

${ }^{99}$ Id. In Rom. 3,8.
} 
Devemos, portanto, crer que em Cristo existiu uma alma humana e racional, sem que necessariamente tenhamos que supor que tivera alguma inclinação ou possibilidade de pecado ${ }^{100}$.

\subsection{0}

\section{Ário e o concílio de Nicéia I (325)}

Até o presente momento vimos os traços subordinacionistas de alguns autores cristãos dos séculos II e III. Agora, ao adentrar no século IV, torna-se mister compreender que é precisamente neste século em que surge uma crucial polêmica na qual se envolverá a lgreja e que por muito tempo mobilizará suas energias: o arianismo.

O arianismo, do nome do sacerdote alexandrino Ário se difundiu aproximadamente a partir de 320. Devemos admitir que as idéias surgidas não são de fato novas, mas ressurgem com um maior vigor e força.

Desde Justino a Orígenes, a idéia de um ou vários intermediários entre Deus, por si mesmo inacessível, e o mundo, sempre constituiu um poderoso elemento de sedução nos teólogos cristãos, capaz de fazê-los prejudicar a plena divindade do Verbo e do Espírito, apresentando-os como se mantivessem com o mundo uma relação indigna do Pai e ligando a própria existência deles à do $\operatorname{cosmos}^{101}$.

Não sabemos dizer ao certo a origem da teologia de Ário, o que de fato podemos afirmar é que ela se relaciona com a linha de reflexão próxima de uma das tendências da filosofia da época. $E$ justamente por não possuir o sentido da fé eclesial de seus predecessores, Ário desenvolve o seu pensamento segundo uma lógica que vai de encontro formalmente com a fé tradicional. A profissão de fé, ou o "símbolo" do concilio de Nicéia (325), que origina o nosso Credo litúrgico, ainda hoje constitui um testemunho do estremecimento provocado e a reação do povo cristão. Pois não se trata somente de uma discussão entre teólogos ou de uma questão política explorada por alguns imperadores contemporâneos. O arianismo é antes de tudo uma questão de lgreja e de fé ${ }^{102}$.

Ao afirmar que o Filho é criatura do Pai, porém a primeira e a mais digna de todas, destinada a ser instrumento para criação de outros seres, Ário, presbítero da lgreja de Alexandria, foi mais longe que os pensadores anteriores.

Ário parte da doutrina trinitária de Orígenes, tradicional em Alexandria, que considerava o Pai, o Filho e o Espírito Santo como três hipóstases, ou seja,

\footnotetext{
100 Id. 2,6,5 Apud QUASTEN, J. Op.cit.

101 LIÉBAERT, J. Os Padres da Igreja., p.135.

102 lbid.
} 
realidades individuais subsistentes distintas entre si e subordinadas uma à outra, embora participando de uma única natureza divina. Assim, Ário acentua de modo radical 0 seu subordinacionismo, provavelmente por reação contra o sabelianismo ${ }^{103}$ e certas concepções demasiado materialistas da geração do Filho pelo Pai. Segundo ele, o Pai é mônade absolutamente transcendente no confronto com o Filho, que lhe é nitidamente inferior, distinto dele tanto pela natureza quanto pela hipóstase, também Deus, mas de nível, autoridade e glória inferiores.

Ao passo que para Orígenes, e também posteriormente para o Bispo Alexandre de Alexandria, o Filho é coeterno ao Pai, que dele é arché ontológica, mas não cronológica, para Ário se o Filho é coeterno ao Pai, deve ser não-gerado como Ele. E como não pode haver dois não-gerados, apesar de o Filho ser anterior a toda criação e ao próprio tempo, ele é posterior ao Pai, do qual recebeu o ser. Assim, houve um momento em que o Filho não existia. Por isto, Ário diz em sua carta a Eusébio de Nicomédia: "Nos perseguem porque afirmamos que o Filho teve princípio, mas que Deus não tem princípio. Por isto nos perseguem, e também porque afirmamos que é do nada. $E$ isto afirmamos porque Ele não é nem parte de Deus nem de outro substrato"104.

Ário não aceita a idéia de que o Filho tenha sido gerado pela substância do Pai, pois implicaria a divisão da mônade divina. Num primeiro momento, ele afirmou que o Filho foi criado do nada por obra do Pai, e em seguida evitou esta expressão, que provocava certo escândalo, e falou da geração do Filho pelo Pai, porém continuou a considerar esta geração como criação, de modo que o Filho seria a única criatura criada diretamente do Pai, todo o mais é obra direta do Filho pela vontade do Pai.

Condenado em um sínodo convocado por Alexandre, Bispo de Alexandria, no ano 318, Ário encontrou defensores no Oriente, fora do Egito, em alguns bispos, antigos discípulos de Luciano, entre os quais o mais influente de todos eles, Eusébio de Nicomédia, entre outros, como Eusébio de Cesaréia que, apesar de não compartilhar o radicalismo do subordinacionismo de Ário, possui um ponto

103 Sabélio, expoente do monarquianismo patripassiano, após ser condenado por volta de 220 em Roma por Calisto, juntamente com seus discípulos, divulga na Líbia e no Egito a doutrina monarquiana e a desenvolve em oposição à teologia do Logos de Orígenes. Em relação ao patripas sionismo original, estes am pliaram a doutrina, encerrando nela o Espírito Santo: um só Deus se manifesta como Pai no AT, como Filho na Encarnação, como Espírito Santo em Pentecostes. Deste modo evitavam a afirmação de Noeto, segundo a qual o próprio Pai havia se encarnado e sofrido. Ainda contra o pens am ento de Orígenes, que afirmava três hipóstases distintas na Trindade, eles sustentavam que Pai, Filho e Espírito Santo constituem um único prósopon e uma hipóstase. Os poucos testemunhos, segundo os quais os sabelianos teriam afirmado três prosopana Trindade, são devidos aos monarquianos de tipo mais moderado. Haja vista que durante o século IV os teólogos do Logos apresentaram cada forma de monarquianismo como sabelianismo. Cf. SIMONETTI, M. Sabellio e il sabellianismo., pp.7-28.

104 QUASTEN, J. Patrologia., p.12. 
de vista doutrinal intermediário ao de Ário e Alexandre. Assim, a dissidência atingia o Oriente e crescia. Para por fim ao desencadeamento de tão violenta polêmica, Constantino convocou em Nicéia o primeiro concílio ecumênico, em que participaram mais de 300 bispos. Aí, Ário e seus defensores foram superados pelos origenianos moderados chefiados por Alexandre e pelos monarquianos de tradição asiática liderados por Marcelo de Ancira e Eustácio de Antioquia. Foi, então redigida uma fórmula de fé em que eram condenadas as proposições arianas fundamentais e o Filho era definido homoousios com o Pai, ou seja, consubstancial, ou da mesma substância. Quase todos se submeteram e assinaram, exceto Ário e dois bispos líbios, que foram condenados e exilados na llíria. E pouco tempo depois foram ainda depostos e exilados na Gália Eusébio de Nicomédia e Teógnis de Nicéia, por continuarem a apoiar os partidários de Ário ${ }^{105}$.

O símbolo do concílio de Nicéia foca ao máximo grau a unidade de Cristo com o Pai. Nas interpolações antiarianas declara-se com maior evidência o objetivo doutrinário do concílio, destinado a combater os erros arianos. $\mathrm{Na}$ ordem em que se apresenta o texto, a primeira formulação é dada pela expressão "isto é, da substância do Pai”'106. Tal expressão rebate as teses arianas segundo as quais o Logos é criado do nada e não há nenhuma comunhão ontológica entre o Pai e o Filho. Assim, o Filho participa plenamente da essência do Pai, introduzindo-se um conceito que é confirmado logo depois pelo termo homooúsios ("da mesma essência" ou "substância") 107.

O termo homoousios, por conta da polissemia de ousia, podia significar que o Filho não só é da mesma substância que o Pai, como também da mesma hipóstase, afirmação esta contrária à doutrina das três hipóstases trinitárias que prevalecia no Oriente, a ponto de ser considerada sabeliana. Além do mais, alguns bispos ficaram um tanto quanto reticentes porque a formulação não era bíblica. Tanto que teria ocorrido uma convergência em torno da expressão "de Deus", que fundamentava-se em Jo 8,42. Contudo, logo percebeu-se que os arianos a usavam, podendo muito bem adaptá-las às suas doutrinas (como de fato faziam ao recordar que 1 Cor 8,6 e 2 Cor 5,18 sustentavam que todas as coisas vêm "de Deus"). Assim, para evitar quaisquer ambiguidades era necessário superar os limites da linguagem bíblica. Portanto, aquela afirmação vinha de encontro às aspirações dos monarquianos, como Marcelo e Eustácio, mas também não

\footnotetext{
105 lbid., pp.10-11

106 DS 125.

${ }^{107}$ ALBERIGO, G. (org.). História dos concílios ecumênicos., pp.26-35.
} 
resultava agradável a muitos, não só a antiarianos mas ainda a antimonarquianos, que assinaram apenas por pressão de Constantino ${ }^{108}$.

A segunda formulação introduzida com nítida função antiariana está na expressão "Deus verdadeiro de Deus verdadeiro". A fórmula quer afirmar contra Ário que o Filho também é verdadeiro Deus em todos os sentidos que o Pai é verdadeiro Deus. A doutrina ariana ressaltava a divina unicidade absoluta do Pai, referindo-se a Jo 17,3, de modo que só o Pai é verdadeiro Pai, enquanto o Filho o é somente por participação. Assim, Eusébio de Cesaréia afirmava que o Pai é "verdadeiro Deus", ao passo que o Logos é "Deus"109.

A próxima fórmula, "gerado, não criado", objetivava rebater uma das idéias mais difundidas do arianismo, a assimilação entre "gerado" e "criado", ou seja, aplicavam indiferentemente ao Filho o termo "gerado" e "criado". Todavia o concílio afirma e defende que o Filho é eternamente gerado do Pai. Precisamente por sua clareza, a expressão "gerado, não criado" não sofrerá ambiguidades depois de 325 , o que não se sucederá com a próxima fórmula "consubstancial ao Pai" (homooúsion tô Patrí) ${ }^{110}$.

O termo chave "consubstancial" (homoousios) - tomado da linguagem filosófica e utilizado por Plotino e Porfírio para designar seres pertencentes a mesma classe e que compartilham o mesmo tipo de conteúdo, e também já presente no âmbito cristão, proveniente da literatura gnóstica, onde indicava a "semelhança no ser" entre seres diferentes, ou uma pertença ao mesmo modo ou grau de ser - visa na verdade repelir qualquer idéia de diferença de natureza ou de "substância" entre o Pai e o Filho, iguais em divindade, isto é, de "mesma substância" e até no sentido dado ao termo depois de Nicéia "uma única substância"111.

O emprego do ponto de vista soteriológico, "só é redimido o que é assumido", axioma de Irineu, assimilado pela teologia alexandrina, prevaleceu no Credo de Nicéia e foi posteriormente desenvolvido por Gregório Nanzianzeno: "O que não foi assumido pelo Logos em sua encarnação também não foi curado; o

\footnotetext{
108 lbid.

109 lbid.

110 lbid.

111 Ibid. Após o Concílio, os arianos tentaram imprimir uma interpretação herética ao termo homoousios, para que não fosse entendido no sentido de identidade quantitativa estrita, mas no sentido de uma identidade qualitativa, que se atribui como predicado extrínseco a dois sujeitos distintos. Os latinos interpretaram o homoousios claramente como referente à unidade substancial; os orientais, influenciados pelo pensamento de Orígenes, entendiam como comunhão apenas genérica de essência; os orientais também pensavam que os ocidentais se aproximavam do modalismo sabeliano, também porque Marcelo de Ancira (+374), apesar de grande defensor do Credo Niceno, retomava a concepção da Trindade da antiga tradição da Ásia menor e de Tertuliano, e acentuava excessivamente a Mônada divina.
} 
que, porém, é unido com Deus também é salvo"112. Contemporaneamente ao Concílio de Nicéia, Atanásio escreveu: "Se o Filho fosse criatura, o homem permaneceria puramente mortal, sem ser unido a Deus (...), o homem não poderia ser divinizado, permanecendo unido a uma criatura, se o Filho não fosse verdadeiro Deus"113.

Portanto, o concílio de Nicéia recusa terminantemente a ideia de um Cristo intermediário cósmico. Ele afirma que em Jesus Cristo está o absoluto de Deus que nós podemos encontrar. O Logos é Deus verdadeiro que entra em nosso mundo, de maneira que cabe aos homens de fé acolhê-lo como Ele se revela ${ }^{114}$.

\subsection{1 \\ Apolinário de Laodicéia}

Apesar de Apolinário ser um dos maiores defensores da doutrina do concilio de Nicéia contra os arianos e de seu pensamento ser precisamente fruto desta oposição, sua cristologia possui fortes traços característicos da doutrina ariana.

Apolinário afirma a unidade da divindade e da humanidade em Cristo. Considerava o pensamento ariano uma possível ameaça a este dogma. A doutrina corrente na escola de Antioquia não o satisfazia, por isso buscava uma solução melhor que excluísse toda tendência a interpretar como uma dupla personalidade a estreita união da divindade e da humanidade em Cristo.

No entanto, a sua própria teoria não era uma solução. Pois a sua teoria mutilava a humanidade de Cristo. Na esteira do pensamento de Platão, Apolinário afirmava que no homem coexistem corpo, alma e espírito. O segundo destes três elementos é a alma irracional ou animal, o princípio da vida; o terceiro, o espírito ou mente é a alma racional, o princípio determinante e controlador. Segundo Apolinário, em Cristo interagiam o corpo humano e a alma irracional, ou seja, o primeiro e o segundo elementos. Mas o mesmo não se dava com o terceiro elemento, o espírito humano, ou alma racional, pois esta teria sido substituída pelo Logos divino. Neste sentido, Cristo teria a divindade completa, mas a humanidade incompleta. Tal solução parecia a Apolinário suficiente para atender às dificuldades de interpretação relativas ao prólogo do evangelho de São João quando nos diz: Verbum caro factum est, que designa a união da divindade do Logos que se uniu somente a corporeidade do homem e habitou como alma no

\footnotetext{
112 ORÍGENES. Ep.101,7 Apud KESSLER, H. Cristologia., p.311.

113 ORÍGENES. II Adv. Ar. 69-70: PG 26, col. 293a-296a Apud SESBOÜÉ, B. Gesù Cristo nella Tradizione della Chiesa., p.97.

${ }^{114}$ LIÉBAERT, J. Os padres da Igreja., p.140.
} 
corpo que recebera da Santíssima Virgem Maria. De modo que Cristo não pode ter uma humanidade completa basicamente por duas razões: uma razão metafísica, segundo a qual dois seres perfeitos, Deus e homem, não podem produzir uma unidade, mas somente um ser híbrido, de maneira que seria absurda a teoria da união da divindade perfeita com a humanidade perfeita em uma só pessoa, pois duas realidades completas ou inteiras não podem estar contidas em uma única outra realidade completa ou inteira; e ainda uma outra razão psicológica, segundo a qual a alma racional constitui a sede e o centro do poder de escolha entre o bem e o mal, o qual atribuiria a Cristo a possibilidade de pecar. Contudo, o Redentor para remir há de permanecer sem pecado ${ }^{115}$.

Apolinário estava convencido de que em Cristo havia uma só natureza. Pois para ele natureza completa significava o mesmo que prosopon. Não é fácil precisar até que ponto tal conclusão era fruto de sua discordância a respeito do uso dos termos phísis, prosopon e hypóstasis. Sem dúvida alguma Apolinário pensou em uma única unidade real e biológica em Cristo, que une diretamente a divindade com seu corpo e forma uma só natureza. Por isso ele via nesta teoria a única explicação para a communicatio idiomatum, para a concepção virginal, para o poder redentor da morte de Cristo e para o caráter salvífico de sua carne, que recebemos na Ceia Eucarística ${ }^{116}$.

A teoria de Apolinário parecia responder facilmente à difícil questão da impecabilidade de Cristo. Ele ainda teria influenciado bispos e feito adeptos em diferentes províncias do Oriente. Mas logo surgiram oposições, visto que sua teoria ia de encontro com a doutrina da lgreja sobre a humanidade completa e perfeita de Cristo. Pois ao negar à pessoa de Cristo uma alma humana, o elemento mais importante da natureza humana, Apolinário esvaziava de sentido o significado da encarnação e da própria redenção. Recordemos que se o Logos se encarnou por nós, não seria possível que assumisse um corpo carente de inteligência. Além disso, o Redentor não redimiu somente o corpo, mas também a alma. Assim, aqui cabe o velho adágio de Irineu segundo o qual Cristo não redimiu o que não assumiu. Daí então a condenação da teoria de Apolinário no concílio ecumênico de Constantinopla em 381.

\footnotetext{
${ }^{115}$ QUASTEN, J. Patrologia., pp.399-401.

116 lbid.
} 


\subsection{2 \\ Controvérsia nestoriana}

Logo após assumir a sede de Constantinopla em 428 Nestório dá largas à abertura das controvérsias cristológicas propriamente ditas que dominarão as discussões teológicas até o século VII. Nascido por volta de 381 na Germanícia (Síria), monge e depois presbítero de formação antioquena, Nestório teria sido aluno de Teodoro de Mopsuéstia e logo se destacado por seu admirável talento na oratória. Como patriarca de Constantinopla procurou combater com veemência os hereges. No âmbito de uma série de iniciativas com o objetivo de restabelecer em Constantinopla a pureza da fé, Nestório chegou a desaprovar publicamente o costume já amplamente espalhado de dar à Maria o nome de "mãe de Deus" (Theotókos). Com efeito, a cristologia antioquena distinguia com máxima precisão em Cristo as propriedades divinas das humanas, de modo que Maria em stricto sensu devia ser considerada somente como mãe de Jesus. Daí Nestório preferir o título mais compreensivo de "mãe de Cristo" (Christotókos). Porém, apesar de se tratar de uma questão contingente que não constitui o ponto-chave de sua teologia, Nestório toma posição a partir de uma perspectiva soteriológica e de terminologia bíblica, levado pela desconfiança de apolinarismo que poderia conter a expressão Theotókos, insinuando a idéia de união física entre a humanidade e a divindade.

$\mathrm{Na}$ verdade quando assumiu a cátedra de Constantinopla tal discussão já estava em curso entre os que defendiam a possibilidade de aplicar à Maria o termo "mãe de Deus" e os que a isso se opunham propondo a expressão "mãe do homem" (anthropotókos). Assim, Nestório por considerar os dois termos suspeitos propõe como solução intermediária a expressão "mãe de Cristo" (Christotókos).

(...) Em todas as passagens em que as divinas Escrituras fazem menção da economia do Senhor, essas mesmas Escrituras atribuem o nascimento e o sofrimento não à divindade, mas à humanidade de Cristo, de forma que, para falarmos com exatidão, dever-se-ia chamar a santa Virgem de mãe de cristo (christotókos) e não mãe de Deus (theotókos). Ouve o Evangelho que proclama: "Livro das origens de Jesus Cristo, filho de Davi. (...) É bom e conforme com a tradição evangélica confessar que o corpo é o templo da divindade do Filho, templo que é unido a ele por uma suprema e divina conjunção, a ponto de a natureza da divindade se apropriar do que pertence a esse templo. Mas sob pretexto dessa apropriação, atribuir (ao Verbo) as propriedades da carne que lhe está unida, quer dizer, o nascimento, o sofrimento e a morte, só pode ser, meu irmão, o fato de um espírito transviado pelos erros dos gregos, ou doente da loucura de Apolinário, de Ário ou de outras heresias, ou de alguma outra doença mais grave ainda. Porque, rigorosamente falando, aqueles que se deixam levar por essa palavra de apropriação deveriam dizer que o Deus Verbo foi, por apropriação, amamentado, 
que cresceu pouco a pouco, e que no momento da paixão teve medo e sentiu necessidade da ajuda de um anjo ${ }^{117}$.

Tal solução proposta revelava sua mais absoluta ignorância da tradição patrística acerca da expressão theotókos, além de tocar em um ponto muito sensível da religiosidade popular, em que o culto mariano ocupava grande espaço no seio das comunidades. A despeito da solução ser proveniente de método teológico fundamentado na autoridade bíblica e conciliar, o mau-humor e os protestos suscitados levaram Nestório a ser acusado de dualis mo cristológico, ou seja, de dividir Cristo, de afirmar dois Cristos e dois Filhos, o homem e o Deus; e ainda de retomar as idéias de Paulo de Samosata a respeito de Cristo como "puro homem", que se tornou Filho de Deus por adoção. Contudo, malgrado tais opiniões terem sido consideradas injustas já pelos historiadores antigos, ${ }^{118}$ por serem desprovidas de uma clara compreensão do método utilizado por Nestório, seu pensamento ficou estigmatizado como expressão de uma visão dualista incapaz de distinguir claramente natureza e pessoa, tendendo assim a conceber as duas naturezas de Cristo como duas pessoas.

Nestório sempre negou estas acusações, pois se preocupara apenas em salvaguardar a integridade da natureza humana, ameaçada pelo apolinarismo, e fazer frente aos alexandrinos que a reduziam a um mero instrumento passivo do Logos. Em sua teoria, ele defendeu tanto a distinção das propriedades das duas naturezas como também a sua unidade, refutando a acusação de pregar dois Cristos. Para exprimir simultaneamente a distinção e ao mesmo tempo a unidade da divindade e humanidade no Cristo, ele usou um linguajar típico da escola antioquena, ou seja, homem assumido pelo Logos, em quem ele habita como que em um templo. Além do mais, de acordo com pesquisas recentes, ele teria captado o sujeito único da encarnação de maneira bastante adequada, recorrendo precisamente ao conceito de prosopon, em que são expressas as propriedades individuais. É nele que Nestório percebe a base da unidade em Cristo, apesar de sua tentativa de explicar o modo da união seja ainda insuficiente. ${ }^{119}$

Entretanto, a confusão e os protestos provocados pelo texto de algumas homilias de Nestório levaram Cirilo, bispo de Alexandria desde 412, a intervir na questão ao criticar o conteúdo dos discursos de Nestório. Mas a ação de Cirilo é animada tanto por motivos doutrinais como políticos. Pois, visto a já tradicional rivalidade entre Alexandria e Antioquia, Cirilo se sentia incomodado com o fato de

117 CIRILO. Lettre 5, PG, 77, 52 B-56 B Apud SPANNEUT, M. Os Padres da Igreja., p.260.

118 SÓCRATES, HE VII 32 Apud ALBERIGO, G. (org.). História dos concílios ecumênicos., p.74.

${ }_{119}$ ALBERIGO, G. (org.). Op.cit. 
um antioqueno de prestígio ocupar a sede de Constantinopla, que já se tornara a principal sede do Oriente. E a sua postura cristológica de tipo alexandrino, que relevava ao máximo a subordinação da humanidade de Cristo à sua divindade, percebia melhor sua unidade e desconfiava de uma distinção nítida demais das propriedades humanas e divinas em Cristo.

A disputa entre Nestório e Cirilo é ícone das divergências cristológicas entre alexandrinos e antioquenos. Diante deste contexto, o Papa Celestino, sem se aprofundar muito na questão, decidiu em favor de Cirilo; em seguida, em um concílio reunido em Roma em agosto de 430, convidou Nestório a reconhecer e renegar seus erros, encarregando Cirilo de entregar-Ihe a notificação que continha a condenação de suas teorias em 12 anátemas e a ordem de retratação formal. Porém, Cirilo só cumpre com sua função em novembro do mesmo ano, e neste ínterim Nestório havia pedido ao imperador Teodósio II a convocação de um concílio ecumênico. Uma vez atendido, o concílio foi aberto em Éfeso na solenidade de Pentecostes do ano seguinte (431) com o intuito de pôr fim às controvérsias e às questões ainda não resolvidas.

O concílio de Éfeso teve um desenrolar muito irregular, e todas as irregularidades foram fruto da iniciativa de Cirilo, cujos seguidores condenaram e depuseram Nestório. Alguns dias depois os seguidores de Nestório, liderados por João de Antioquia, condenaram e depuseram Cirilo. Diante desta irregularidade Teodósio aprovou ambas condenações e deposições. Porém, aquela contra Cirilo, de volta ao Egito, permaneceu inoperante, ao passo que Nestório renunciou espontaneamente a uma defesa ulterior e se retirava para um mosteiro em Antioquia. Negociações realizadas posteriormente entre João de Antioquia e Cirilo levaram à reconciliação em abril de 433: os antioquenos renunciaram a Nestório, aprovando sua condenação; Cirilo renunciou aos 12 anatemismos. A fórmula de fé, também ficará conhecida como Fórmula de União, aprovada por ambas as partes, afirmava que no único Cristo Filho e Senhor se dera a união das duas naturezas, humana e divina, sem confusão, de modo que ele é consubstancial ao Pai pela divindade e consubstancial a nós pela humanidade, e Maria é definida Theotókos. A partir daí Nestório foi exilado primeiramente para Petra e logo após para o grande Oásis, no deserto Líbico. Viveu ainda até o concílio de Calcedônia (451), e em sua posterior defesa em Livro de Heráclides afirmou a congruência de sua doutrina com o Tomus ad Flavianum de Leão Magno.

O concilio de Éfeso não faz propriamente nenhuma definição dogmática. Contudo, a Fórmula de União constitui o "credo de Éfeso", que une substancialmente este concîio ao de Calcedônia. A fórmula contém em si 
elementos essenciais da cristologia de Alexandria e de Antioquia. Tal fórmula é de suma importância, pois as duas escolas doutrinais encontram um modo de expressar a consciência da fé eclesial a partir não somente de uma corrente de pensamento.

Em suma, o problema de Éfeso era a compreensão da unidade de Jesus Cristo, verdadeiro Deus e verdadeiro homem. Neste sentido, a fórmula do concílio afirma que o Logos assumiu a verdadeira humanidade mediante a união hypostática e que a conjunção das duas naturezas perfeitas se dá num só prósopon.

Confessamos, portanto, nosso Senhor Jesus Cristo, Filho unigênito de Deus, perfeito Deus e perfeito homem, composto de alma racional e de corpo, antes dos séculos gerado do Pai segundo a divindade, no fim dos tempos nascido, por causa de nós e de nossa salvação, da Virgem Maria, segundo a humanidade, consubstancial ao Pai segundo a divindade e consubstancial a nós segundo a humanidade. Aconteceu, de fato, a união das duas naturezas, e por isto nós confessamos um só Cristo, um só Filho, um só Senhor. Segundo este conceito de união inconfusa, confessamos a santa Virgem deípara, porquanto Deus, o Verbo, foi encarnado e em-humanado e, desde a conceição mesma, uniu a si o templo que dela recebeu. Quanto às expressões evangélicas e apostólicas que dizem respeito ao Senhor, sabemos que os teólogos aplicam algumas indiferentemente como referidas a uma única pessoa, enquanto distinguem outras como referidas a duas naturezas, atribuindo as dignas de Deus à divindade de Cristo, as mais humildes à sua humanidade ${ }^{120}$.

${ }^{120}$ Fórmula de União entre Cirilo de Alexandria e os bispos da Igreja de Antioquia. Cf. DS, n.272. 


\section{3 O Concílio de Calcedônia}

Vinte anos separam os concílios de Éfeso e Calcedônia. Tempo em que se precisou a linguagem e o significado das afirmações da união das duas naturezas em Cristo, fazendo com que ambos os concílios tenham entre si uma íntima e profunda ligação, que desde a antiguidade foram semprealvo de sumaveneração tanto no Oriente, que os recorda na própria liturgia, como no Ocidente, segundo o testemunho de São Gregório Magno, que os exalta e os coloca no mesmo plano que os de Nicéia e Constantinopla, celebrados no século anterior: "Neles como em pedra quadrangular se assenta o edifício da fé, e quem não se radicar na sua solidez, seja qual for a vida e feitos que tiver, poderá talvez apresentar a firmeza da pedra, mas estará fora do edifício"121.

Ao lançarmos luz sobre o grande concilio de Calcedônia descobriremos dois pontos principais: o primado do romano pontífice, que brilhou manifestadamente na agitada controvérsia cristológica, e o grandíssimo alcance da definição dogmática de Calcedônia. Contudo, ressaltaremos o quanto possível apenas o segundo ponto principal, ou seja, tudo aquilo que tange a cristologia da definição dogmática de Calcedônia.

Entretanto, para proceder com ordem tomemos do princípio a exposição que se segue neste capítulo. Dado o apaziguamento a que chegavam as questões religiosas no Oriente e, sobretudo tendo presente o antagonismo das duas rivais, Antioquia e Alexandria, nas questões cristológicas, necessariamente teria que ser produzido em Alexandria uma reação em favor do monofisismo como réplica ao nestorianismo patrocinado em Antioquia.

Como conseqüência do concílio de Éfeso de 431 e da Fórmula de União de 433, Antioquia sofreu um golpe muito forte. De modo que Alexandria pensava triunfar suas idéias. Ao ser proclamada em Éfeso a união das duas naturezas na única pessoa de Cristo, os alexandrinos pensaram ter sido consagrada a tendência de sua escola, mesmo que Cirilo, seu maior expoente, tenha eliminado algumas expressões que pareciam indicar sua crença de que a união das duas

121 GREGÓRIO M. Registrum Epistularum, I, 25 (AL. 24): PL 77, 478; ed. Ewald, I, 36 ApudSR., n. 2. 
naturezas em Cristo as tornava uma só. Assim, Cirilo manifestou bem claramente em sua controvérsia com João de Antioquia e Teodoreto de Ciro que não admitia outra união senão aquela proclamada em Éfeso.

Mas nem todos os alexandrinos e nem todos os partidários e discípulos de Cirilo teriam idéias tão claras e distintas sobre a união das duas naturezas em Cristo. Assim, influenciados pelas tendências da escola, de enxergar a união como fusão das duas naturezas em uma, se revoltaram contra as concessões de Cirilo e, naturalmente, não aceitaram as decisões dos sínodos precedentes em que se falava de duas naturezas. Para eles dizer duas naturezas equivaleria a dizer duas pessoas. Os antioquenos, por sua vez, queriam obter a reabilitação de Nestório, em particular Teodoreto de Ciro que escreverá em 447 uma obra cristológica contra os monofisitas, o Eranistes ou Mendigo ${ }^{122}$, em que ele denuncia o proliferamento de novas idéias no campo monofisita.

Proclo, novo patriarca de Constantinopla, proporá uma cristologia consideravelmente equilibrada e reconciliadora. Ele chega a afirmar expressamente: A economia grandiosa da salvação uniu as duas naturezas em uma hipóstase ${ }^{123}$; tal fórmula, em certo sentido, adianta aquela que será definida em Calcedônia. O Tomo aos armênios, escrito por Proclo em 435, já propõe uma fórmula de conciliação aceita tanto por Cirilo como por João de Antioquia: Confesso uma só hipóstase do Verbo encarnado ${ }^{124}$. Porém, ao pretender substituir a fórmula de "uma só natureza", retomando a de Éfeso, se distancia daquela proposta por Cirilo.

Dióscoro, sucessor de Cirilo na sede de Alexandria, era o porta-voz da nova reação sobre aquilo que eles consideravam um retorno e continuação do apolinarismo. Segundo os seus princípios fundamentais na união do Verbo com a natureza humana, esta era absorvida pela natureza divina, de maneira que na união prevalecesse uma só natureza: a divina. Neste sentido, Cristo era Deus, mas não era homem perfeito.

Para apoiar tal doutrina, como era de costume, recorriam ao testemunho dos Padres, e este era o grande instrumento a que lançavam mão os partidários do monofisismo. Segundo eles, Santo Atanásio, São Gregório Taumaturgo, o papa Julio e, sobretudo, São Cirilo não haviam defendido outra coisa. Dióscoro, patriarca de Alexandria, era na verdade aquele que dava vida a todo este movimento.

\footnotetext{
122 SESBOÜÉ, B. História dos Dogmas., p.335.

${ }^{123}$ Ibid., p.335.

124 lbid.
} 
No entanto, o grande iniciador da controvérsia que conduziu à convocação do concílio de Calcedônia foi Êutiques, sacerdote e arquimandrita de um dos mais importantes mosteiros de Constantinopla. Considerado protótipo da ortodoxia e desejando impugnar a heresia de Nestório, que afirmava haver duas pessoas em Cristo, caiu no erro oposto ${ }^{125}$.

Êutiques, adjetivado por São Leão Magno como alguém "muito imprudente e assaz pouco instruído"126, de fato não era grande pensador nem homem original, mas as circunstâncias o elevaram ao posto de homem certo para defender aquilo que considerava ortodoxia, ou seja, o monofisismo. A partir daí passou a afirmar de maneira mais incisiva que se deviam distinguir dois momentos relativos à encarnação: antes e depois. Antes da encarnação Cristo possuía as duas naturezas: a humana e a divina; contudo, depois da "união" passou a existir uma só natureza, sendo o homem absorvido pelo Verbo. Assim, de Maria Virgem nasceu o corpo do Senhor, que por sua vez não é da mesma substância e matéria que o nosso. A despeito de ser humano, não é consubstancial a nós nem àquela que o deu à luz segundo a carne ${ }^{127}$. Com efeito, não foi numa verdadeira natureza humana que Jesus Cristo nasceu, padeceu, foi crucificado, morto e ressurgiu ao terceiro dia.

Contudo, muito acertadas são as palavras de Leão ao refutar o pensamento de Êutiques em carta enviada a Flaviano, bispo de Constantinopla:

\begin{abstract}
O mesmo sempiterno unigênito do Genitor sempiterno "nasceu do Espírito Santo e de Maria virgem". Este nascimento temporal em nada diminuiu-Ihe o nascimento divino e sempiterno, nem nada the acrescentou; mas ele se dedicou todo a recuperar o homem, que tinha sido enganado, com o fim de vencer a morte e de destruir com a sua força o diabo, que tinha o domínio da morte. De fato, não poderíamos vencer o autor do pecado e da morte, se não assumisse a nossa natureza e a fizesse sua aquele que nem o pecado pôde contaminar, nem a morte deter ${ }^{128}$.
\end{abstract}

E ainda:

Ou talvez [Êutiques] pensou que o nosso Senhor Jesus Cristo não teve a nossa natureza, porque o anjo, mandado à bem-aventurada Maria, diz: O Espírito Santo descerá sobre ti e o poder do Altíssimo te cobrirá com sua sombra; por isso, o santo que nascer de ti será chamado Filho de Deus" [LC 1,35] - como se a carne do concebido não fosse da natureza da parturiente porque a conceição da Virgem foi obra divina! Ao contrário, aquela geração singularmente admirável e admiravelmente singular não se deve entender no sentido de que, pela novidade da criação, seja removido o que é próprio de gênero: foi o Espírito Santo que deu à Virgem a fecundidade, mas a verdade do corpo foi tomada do corpo e, "edificando a Sabedoria uma casa para si" $[\operatorname{Pr} 9,1]$, "o Verbo se fez carne e habitou entre nós"

125 SR., n. 4.

${ }^{126}$ LEẪ M. Ep.28 ad Flavianum, 1: PL 54, 755s Apud SR, n. 5.

127 FLAVIANO. Ep.26 ad Leonem M.: PL 54, 745 Apud SR, n. 5.

128 LEÃO M. Tomus ad Flavianaum, Cap.2; DS, n. 291. 
[Jo 1,14], isto é, naquela carne que tomou do homem e que o espírito da vida racional animou ${ }^{129}$.

A Êutiques se juntou o patriarca Dióscoro e Crisáfio, o grande dignitário da corte que gozaria do beneplácito de Teodósio II. Com isso, já compreende-se a força que rapidamente adquiriu o monofisismo.

Frente a tal corrente elementos muito valiosos da verdadeira ortodoxia eram alienados. Contudo, a campanha monofisita de Êutiques encontrou em Eusébio bispo de Doriléia um grande adversário, que o acusou de depreciar o ensinamento de Nicéia e as doutrinas de Cirilo proclamadas em Éfeso. Eusébio queria na verdade se referir à "fórmula de união", com o seu reconhecimento explícito das duas naturezas.

Uma vez acusado de heresia por Eusébio de Doriléia, Êutiques foi condenado no sínodo particular reunido em Constantinopla em 448 sob a presidência de São Flaviano, bispo desta cidade. Ele, porém, considerando injusta sua condenação, pois estava convencido de que só fazia reprimir a renascente heresia de Nestório, além de ratificar seu pensamento que parecia por em dúvida a consubstancialidade humana de Cristo, reforçando assim a fórmula da "única natureza", ou seja, a das duas naturezas antes da união, que resultava em uma só depois desta; ainda recorreu para a sentença de alguns bispos de reconhecida autoridade. Tais recursos, que eram na verdade cartas de apelação, chegaram também ao bispo da Sé Apostólica, o ilustre São Leão Magno, admirado ao longo dos séculos por seu vigilante empenho em promover a religião e a concórdia, em defender a verdade e a dignidade da cátedra romana, e, como não poderia deixar de ser, por sua destreza no governo e eloqüência harmoniosa. Ninguém melhor e mais capaz que ele para impugnar o erro de Êutiques, visto que em suas alocuções e em suas cartas não cessava de proclamar o mistério de uma pessoa e duas naturezas em Cristo. "A lgreja católica vive e prospera pela sua fé nesta verdade: que em Jesus Cristo não se deve crer a humanidade sem verdadeira divindade, nem a divindade sem verdadeira humanidade". ${ }^{130}$

\section{1 \\ O "latrocínio" de Éfeso}

Por meio de Dióscoro e Crisáfio, Êutiques conseguiu que o imperador enviasse cartas favoráveis ao Papa. O mesmo fizeram outros influentes

\footnotetext{
$129 \mathrm{lbid}$

${ }^{130}$ LEÃO M., Ep.28 ad Flavianum, 5: PL 54, 777 Apud SR, n. 9.
} 
partidários da campanha empenhada por Êutiques, o que despertou o interesse do Romano Pontífice a respeito da nova doutrina e de seu principal promotor. Ao mesmo tempo, fizeram o possível para obter a adesão de Flaviano.

São Leão Magno logo se deu conta da gravidade da situação. No entanto, precisava ganhar tempo a fim de conseguir informações objetivas por meio de seus homens de confiança, mais precisamente de Flaviano e de Teodoreto de Ciro. Assim, enviou uma carta ao imperador na qual agradecia cordialmente seu interesse pela unidade religiosa e lhe anunciava que tão logo recebesse as informações que esperava daria uma resposta definitiva.

Chegadas as informações esperadas por intermédio de Flaviano, patriarca de Constantinopla, Leão Magno de fato se convenceu da gravidade do assunto. Ele realmente era o homem mais adequado para resolver o problema. Decidido e enérgico, como mais tarde se mostrou enfrentando Átila, rei dos hunos, mas ao mesmo tempo grande teólogo, Leão deu a resposta mais apropriada: a célebre Epístola dogmática, ou Tomus ad Flavianum (449), na qual era exposta a doutrina católica sobre as duas naturezas de Cristo em uma só pessoa. A Epístola, tipo e modelo dos documentos dogmáticos do Bispo de Roma, também enviada ao Oriente, deveria ser admitida por todos como norma de fé. Ela estava destinada a constituir a base de todas as discussões que deviam se seguir mais tarde, e antes de tudo das próprias definições do concilio de Calcedônia.

Êutiques e Dióscoro, como era de se temer, não aceitaram a solução do Papa contida na Epístola dogmática, que condenava sua teoria. Assim, Êutiques, por meio de Crisáfio, íntimo seu e grande amigo de Teodósio II, conseguiu obter do imperador que sua causa fosse novamente examinada e se reunisse outro concílio em Éfeso, sob a presidência de Dióscoro, que, diga-se de passagem, era amicíssimo de Êutiques e inimigo de Flaviano. Dióscoro, equivocado pela aparente semelhança das doutrinas, afirmava que, assim como Cirilo, seu predecessor, havia defendido a doutrina de uma só pessoa em Cristo, assim Ihe cabia defender com todas as forças uma só natureza em Cristo, depois da "união". Leão Magno, como uma iniciativa apaziguadora, chegou a enviar a Éfeso os seus legados, que levaram consigo, entre outras, duas cartas, uma ao sínodo, outra a Flaviano, nas quais os erros de Êutiques eram refutados.

Entretanto, o Sínodo Efesino foi transtornado pela violência sob as ordens de Dióscoro e Êutiques. De modo que os Legados Pontifícios foram impedidos de exercer a presidência, foi proibida a leitura das cartas do Bispo de Roma e os votos dos bispos foram extorquidos através de fraudes e ameaças. Flaviano, entre outros, foi acusado de heresia, deposto de sua sede e jogado na prisão, onde 
passou o resto dos seus dias. Mais tarde, a insanidade de Dióscoro o levou ao ponto de excomungar o Papa, a suprema autoridade apostólica.

Toda esta austera repressão a qualquer tipo de oposição atraíra a severa condenação do Papa Leão, que qualificará o segundo concílio de Éfeso como "latrocínio". Sua reação imediata foi a organização de um sínodo em Roma, que reprova e invalida tudo o que se fez em Éfeso. Tal atitude é eclesiologicamente significativa, pois exprime a autoridade do Papa perante o concílio que, de um lado, não é confirmado pelo Bispo de Roma e que, do outro, não será objeto de nenhuma recepção pela Igreja.

Flaviano e Teodoreto de Ciro recorreram ao Pontífice. São sintomáticas as palavras de Flaviano:

Como tudo se voltasse contra mim com premeditação, depois que (Dióscoro) proferiu contra mim aquela injusta sentença, de acordo com os seus desejos e apesar de eu ter apelado para a Sé Apostólica de Pedro, príncipe dos apóstolos, e para todo o sínodo, sujeito à vossa santidade, logo me rodeou multidão de soldados e impedindo-me que me refugiasse junto do altar como tentava, procuraram arrastar-me para fora da lgreja ${ }^{131}$.

Bem como as de Teodoreto:

Se Paulo, pregoeiro da verdade (...) recorreu ao grande Pedro (...) muito mais nós, humildes e pequeninos (...) recorremos à vossa Sé Apostólica, a fim de recebermos de vós um remédio para as feridas da lgreja. A vós compete em todas as questões ter a suprema autoridade. (...) Eu espero a sentença da vossa Sé Apostólica. (...) Antes de mais nada peço que me digais se me devo conformar ou não com esta deposição injusta: espero a vossa decisão ${ }^{132}$.

O monofisismo parecia triunfar, visto que a política imperial continuava a apoiar a referida postura. Mas eis que começam a surgir os protestos dos derrotados. Após o apelo de Flaviano e Teodoreto junto ao Papa, um sínodo reunido em Romano aniversário de eleição de Leão, rejeitou as decisões de Éfeso (29 de setembro de 449) e a 13 de outubro de 449 o Papa escreve a Teodósio II (Ep. 44) solicitando a convocação de um concílio em território italiano, de modo que este reparasse as injustiças cometidas em Éfeso. A solicitação revela-nos três aspectos importantes da conjuntura que tratamos: o embaraço nas relações entre as duas partes da cristandade, a preocupação de que o novo concílio tivesse a mesma força participativa vista no Efesino II e a consciência da imprescindível instância conciliar para regular uma questão dogmática de vital importância, malgrado a crescente consciência da autoridade da sede romana ${ }^{133}$.

${ }^{131}$ SCHWARTZ. Acta Conciliorum Oecumenicorum, II, vol. II, parte I, p.78 Apud SR, n. 12.

132 TEODORETO. Ep.52 ad Leonem M.1.5.6: PL 54,847 e 851; cf. PG 83, 1311s. e 1315s ApudSR, n. 12.

${ }^{133}$ ALBERIGO, G. (org.). História dos concílios ecumênicos., pp.91-92. 
Com Leão as pretensões primaciais de Roma atingem o seu ponto mais alto, porém, sem excluir o princípio sinodal. Na verdade, os dois princípios, primacial romano e sinodal, coesixistiam, mesmo em meio a atritos e incongruências entre ambos, acrescentando ainda a figura do imperador cristão, cuja particular função de tutelar a fé é reconhecido por Leão. Os sermões do Pontífice, antes e depois de 451, demonstram que a relação entre papado e concílio coloca-se sobretudo, em termos de correlação dialética e não apenas de superioridade do primeiro sobre o segundo; a despeito do Papa ter agido autoritativamente já no princípio do conflito monofisita, inclusive expondo a sua própria decisão de fé e reivindicando a primazia da sede romana de modo diverso e mais incisivo de todos os seus predecessores ${ }^{134}$.

As iniciativas de Leão em vista de por fim aos abusos ficaram sem resposta. Mas em 450 ele consegue do imperador do ocidente, Valentiniano III, o compromisso de trabalhar pela convocação de um concílio ecumênico na Itália. Tudo em vão. Teodósio II nada fez para reparar o "latrocínio" de Éfeso. No entanto, morrendo ele improvisamente, passou a reinar sua irmã Pulquéria, que casou-se com Marciano e o associou ao Império. Subindo ao trono ainda em 450, ele logo dá sinais de que abandonaria o caminho trilhado por seu predecessor.

Pulquéria e Marciano tornam-se notáveis na história da lgreja pela sua inclinação ao entendimento com Roma e pela revisão do julgamento de 449. Assim, Anatólio, ilegitimamente posto por Dióscoro em lugar de Flaviano na sede de Constantinopla, subscreve o Tomus de Leão, que é transmitido a todos os metropolitas para que fizessem o mesmo. De modo que Roma podia dar-se por satisfeita em suas exigências, pois até os bispos depostos foram restituídos às suas sedes. Assim, já não mais parecia necessária a convocação de um concílio, até mesmo porque as invasões dos bárbaros tornavam insegura a situação do Império Romano. Contudo, por desejo de Marciano e com a anuência de Leão o concílio é convocado para $1^{\circ}$ de setembro de 451 em Nicéia. Porém, dadas as dificuldades geográficas para o imperador se fazer presente, Marciano decide então transferir o concílio para Calcedônia, cidade bem mais próxima de Constantinopla, na margem asiática. Assim poderia sem dificuldades fazer as idas e vindas necessárias. 


\section{2 \\ O Tomus ad Flavianum}

Antes de adentrarmos propriamente no concílio de Calcedônia faz-se mister fazer algumas considerações a respeito do documento de São Leão Magno intitulado Tomus ad Flavianum, ou Carta Dogmática, que não pôde ser lido em Éfeso, mas que terá um papel decisivo em Calcedônia. O Tomus ad Flavianum, escrito em 448 por Leão, se destaca das demais correspondências escritas pelo Pontífice a Flaviano porque além de refutar a heresia eutiquiana, também refutava outras correntes de pensamento equivocadas do século $\mathrm{V}$, contribuindo, como já dito, decisivamente na elaboração da fórmula de Calcedônia.

O Tomus não é apenas uma carta, é um tratado teológico sobre a relação entre as duas naturezas em Cristo: humana e divina. Ela era acompanhada de uma série de depoimentos extraídos dos mais respeitados Padres Gregos e Latinos, recolhidos com a colaboração de Próspero. Há quem especule que o Tomus tenha sido na verdade obra de Próspero de Aquitânia ${ }^{135}$.

Leão Magno não era muito entrosado com a língua grega ${ }^{136}$, porém a sua contribuição no Concílio de Calcedônia foi decisiva, sobretudo ao precisar a relação entre as duas naturezas humana e divina unidas em Cristo, como foi dito, distinguindo a unidade da pessoa e a duplicidade das duas naturezas em Cristo. Tal precisão fez com que as principais tensões entre as duas Escolas orientais fossem suavizadas.

É possível perceber no Tomus dois principais elementos. Primeiramente, percebemos a concordância com a cristologia de Cirilo ao afirmar a unidade de Cristo para além de qualquer ambigüidade. Por outro lado, a sua linguagem é muito próxima da linguagem da Escola de Antioquia, ao falar deliberadamente que as "duas naturezas" no Cristo conservam as suas propriedades e constituem dois princípios naturais de ação ${ }^{137}$.

Leão Magno muito mais que um teólogo é um homem de governo e um pregador. Contudo, sua originalidade e o serviço prestado por sua teologia à lgreja foram de grande valia, sobretudo no Concílio de Calcedônia, e reconhecidos em 1754 com o título de "Doutor da Igreja" pelo papa Bento XIV ${ }^{138}$. Para ele o importante era impor a linha ortodoxa e tradicional da lgreja mais que aprofundar ou elaborar uma nova ${ }^{139}$.

135 SESBOÜÉ, B. História dos Dogmas., p.339.

${ }^{136}$ HAMMAN, A. Os Padres da Igreja., p.260.

137 SESBOÜE, B. Op.cit., p.135.

138 HAMMAN, A. Op.cit., p.260.

${ }^{139}$ MORESCHINI, C.; NORELLI, E. História da Literatura Cristã Antiga Grega e Latina., p.132. 
São de capitais importância os limites próprios da língua latina com a qual Leão Magno se expressava. Apesar de os gregos acusarem o latim de ter um vocabulário pobre ${ }^{140}$, isto facilitou a Leão Magno expressar de maneira precisa as duas naturezas em Cristo e as suas relações.

O Tomus de Leão é muito próximo de seus célebres sermões sobre a encarnação, que ele proferia nas festas do Natal e da Epifania, e é marcado pelas alternâncias simétricas, recurso estilístico apropriado para sublinhar as diferenças das duas naturezas de Cristo, baseado, sobretudo no vocabulário teológico de Tertuliano e de Agostinho ${ }^{141}$.

No Tomus percebemos (como depois se dará na "Fórmula de Calcedônia") que Leão não prioriza a perspectiva dinâmica do Verbo que se torna homem, mas a perspectiva estática de Cristo, em quem se encontram os componentes humano e divino. Assim, Leão enfatiza decisivamente a verdade de ambas as dimensões, difundindo-as em todo o texto do Tomus, como já se disse, servindo-se de paralelismos e antíteses ${ }^{142}$.

As antíteses são, porém, articuladas no único sujeito, Cristo, assinalado frequentemente com o termo "mesmo", o que garantirá, como veremos adiante, o equilibrio da doutrina de Leão Magno e da sua exposição. Ao acentuar a unidade em Cristo, que como sujeito último tem o próprio Verbo encarnado, Leão Magno se aproxima dos antioquenos ${ }^{143}$.

\begin{abstract}
Assim, pois, sendo mantidas salvas as propriedades de ambas as naturezas reunidas em uma só pessoa, a humildade foi assumida pela majestade, a fraqueza pela força, a mortalidade pela eternidade e, para saldar a dívida de nossa condição a natureza inviolável se uniu à natureza passível, de tal sorte que como convinha à nossa cura, um só e mesmo "mediador de Deus e dos homens, o homem Cristo Jesus" fosse ao mesmo tempo capaz de morrer de um lado, e de outro incapaz de morrer. Foi portanto na natureza intacta e perfeita de um homem verdadeiro que o verdadeiro Deus nasceu, completo no que Ihe é próprio, completo no que nos é próprio [...]. Por conseguinte, aquele que, subsistindo em sua forma de Deus, fez o homem, foi feito homem na forma de servo: uma e outra natureza retém sem defeito o que lhe é próprio e, assim como a forma de Deus não suprimiu a forma de servo, assim a forma de servo não diminuiu a forma de Deus ${ }^{144}$.
\end{abstract}

Percebemos neste fragmento em Leão Magno, como em Tertuliano, a afirmação da preservação sem confusão das duas naturezas após a união das mesmas em Cristo. As propriedades de cada natureza, ou de cada "forma", permanecem intactas em sua totalidade. Não há confusão alguma entre as duas

\footnotetext{
140 SESBOÜÉ, B. História dos Dogmas., p.341.

${ }^{141}$ ALTANER, B. Patrologia., p.360; SESBOÜÉ, B. Op.cit., p.339.

142 SERENTHÀ, M. Jesus Cristo ontem, hoje e sempre., p.268.

143 lbid., p.269.

144 Tome à Flavien, COD II-1, p.183 Apud SESBOÜÉ, B. História dos Dogmas., p.340.
} 
e nem perda ou diminuição em nenhuma delas. A humanidade em nada é suprimida ou absorvida pela divindade. É através da unidade concreta em uma só e mesma pessoa, Jesus Cristo, que se dá a comunhão destas naturezas ${ }^{145}$. É como podemos ler neste outro fragmento:

\begin{abstract}
Eis, portanto, que o Filho de Deus entra nestes lugares mais baixos do mundo, descendo do trono celeste, sem todavia abandonar a glória de seu Pai, gerado numa nova ordem e por um novo nascimento. Uma nova ordem porque, invisível no que é seu, ele foi tornado visível no que é nosso; infinito, quis ser contido; subsistente antes de todos os tempos, começou a existir no tempo; Senhor do universo, cobriu de sombra a imensidão de sua majestade, tomou a forma de servo; Deus impassível, não desdenhou de ser homem passível; imortal, de se submeter às leis da morte. Gerado por um nascimento novo, porque a virgindade inviolada, sem conhecer a concupiscência, forneceu a matéria da carne. Da mãe do Senhor foi assumida a natureza, não a falta, e no Senhor Jesus Cristo gerado do seio de uma virgem, o maravilhoso nascimento não faz que sua natureza seja diferente da nossa. Porque aquele que é verdadeiro Deus é, o mesmo, homem verdadeiro. Nesta unidade não há mentira, tão logo a humildade do homem e a elevação da divindade se envolvem uma na outra. Porque assim como Deus não é mudado pela misericórdia, o homem não é absonvido pela dignidade. Porque ambas as formas cumprem sua tarefa própria na comunhão com a outra. O Verbo operando o que é do Verbo, a carne efetuando o que é da carne. Um dos dois resplandece nos milagres, a outra sucumbe aos ultrajes ${ }^{146}$.
\end{abstract}

Aqui se nota o equilíbrio das expressões com as quais Leão Magno expressa as apropriações da humanidade que o Verbo fez ao se encarnar. Nestas expressões já vislumbramos a expressão "um e o mesmo" que articulará, com o mesmo equilíbrio, a Fórmula de Calcedônia ${ }^{147}$. Esta expressão, que remonta a Irineu, é citação de 1 Tim 2,5 e é frequente tanto nas suas Cartas (p.ex., Ep. 124,2) quanto nos seus sermões (p.ex., Serm. 96, que refuta a heresia de Êutiques). É comose lê neste outro fragmento do Tomus: "[...] Para fazer o que era congruente para trazer remédio para o nosso ser, o único e o mesmo mediador entre Deus e os homens, o homem Jesus Cristo, fez com que, de um lado, pudesse morrer, e por outro, não pudesse morrer" 148 .

Em sua refutação a Êutiques, Leão Magno limita-se sobretudo à noção eutiquiana de que Cristo não nos seria consubstancial, e vê nisso uma nova forma de docetismo. Por este motivo, Leão insiste sobre a realidade da "carne" de Cristo:

[Êutiques] deveria ao menos escutar com ouvido atento a confissão comum e unânime pela qual a universalidade dos fiéis faz profissão de crer em Deus Pai todopoderoso e em Jesus Cristo seu filho único, Nosso Senhor, que nasceu do Espírito

\footnotetext{
145 SESBOÜÉ, B. Op.cit., p.340s.

146 Tome à Flavien, COD II-1 Apud SESBOÜÉ, B. Op.cit., p.341.

147 SESBOÜÉ, B. Op.cit., pp.343-342.

148 Tome à Flavien, COD II-1, p.183 Apud SESBOÜÉ, B. Op.cit., p.340.
} 
Santo e da Virgem Maria, três proposições com as quais se destroem as máquinas de guerra de quase todos os hereges ${ }^{149}$.

A cristologia leonina consiste em expor claramente a dualidade das duas naturezas que se unem numa só pessoa. A despeito de sua linguagem claramente diofisita após a união, jamais tende a admitir dois sujeitos no Cristo.

Leão Magno, assim como Tertuliano, afirma a não confusão das duas naturezas após a união sem nenhuma ambiguidade. Como em FI 2,7, as propriedades de cada natureza permanecem intactas e completas, sem confusão alguma entre elas. De modo que a humanidade em nada é suprimida ou absorvida pela divindade. Mas a comunhão das duas naturezas se dá na unidade concreta de uma só e mesma pessoa, de um só e mesmo sujeito, ou seja, Cristo Jesus: "Assim é mantida a realidade particular de uma e da outra substância, de tal sorte que o Espírito, de uma parte, cumpria em si o que lhe era próprio, virtudes, prodígios e sinais, e que a carne sofria, por seu turno, os sentimentos"150.

Como já referido por nós anteriormente, a falta de habilidade do Pontífice com o grego facilitava-Ihe a franca admissão de duas naturezas em Cristo. O latim desconhece o termo hipóstase, cuja tradução frequentemente oferecia grandes dificuldades; conhecia, porém, o binômio pessoa/natureza. $O$ termo latino persona era o correspondente do grego prosopon, porém mais consistente que este. Ele era suficiente para a sólida profissão da unidade de Cristo. Leão, seguindo a herança de Tertuliano, mostra que o termo latino persona corresponde qualitativamente ao sujeito de Cristo, no qual se dá a unidade das naturezas divina e humana, e assim corrige e supera a expressão ciriliana "unidade física" ${ }^{151}$. Por isso, o elemento mais marcante do Tomus é a afirmação de que a união numa pessoa não faz desaparecerem as características próprias de cada uma das duas naturezas. Desta maneira, Leão Magno satisfez os antioquenos e superou o IV anátema de Cirilo que negava a atribuição das propriedades distintamente às duas naturezas e fazia do Verbo o único princípio de operação no Cristo ${ }^{152}$.

Embora que em nosso Senhor Jesus Cristo a pessoa de Deus e do homem seja uma, outra coisa é aquilo por que os ultrajes são comuns a ambos, outra coisa aquilo por que a glória lhe é comum. Daquilo que é nosso, de fato, ele detém a humanidade, inferior ao Pai; do Pai ele detém a divindade, igual ao Pai. Em razão, pois, desta unidade da pessoa que deve ser discernida numa e noutra natureza, lêse ao mesmo tempo que o Filho do homem desceu do céu, quando o Filho de Deus assumiu uma carne formada da Virgem da qual nasceu, e inversamente diz-se que o Filho de Deus foi crucificado e sepultado, embora tenha sofrido tudo isso não na divindade mesma pela qual é o Filho único coeterno e consubstancial ao Pai, mas

\footnotetext{
149 Tome à Flavien, COD II-1, p.181 Apud SESBOÜÉ, B. Op.cit., p.340.

150 TERTULIANO, Contre Praxéas, 27,11; cf. supra, p.177 Apud SESBOÜÉ, B. Op.cit., p.340.

151 GRILLMEIER, A. Gesù il Cristo nella fede della Chiesa., p.950.

152 SERENTHÀ, M. Jesus Cristo ontem, hoje e sempre., p.269.
} 
na fraqueza da natureza humana. Por isso nós todos professamos também no Símbolo que o Filho único de Deus foi crucificado e sepultado, segundo a palavra do apóstolo: 'pois, se a tivessem conhecido [a sabedoria de Deus], não teriam crucificado o Senhor da glória'. ${ }^{153}$

Percebemos que com a unidade concreta na distinção das duas naturezas permite recorrer à comunicação dos idiomas, que significa o intercâmbio das propriedades das naturezas de Cristo, como os Capadócios e Cirilo já haviam tratado, numa reciprocidade perfeita, que se dá na unidade da pessoa. O termo "pessoa" aqui é correspondente ao grego hypostasis. Assim, cada natureza está imediatamente em questão à pessoa de Cristo no que concerne seja à divindade, seja à humanidade ${ }^{154}$.

Foi com todo direito que [Pedro] foi proclamado bem-aventurado pelo Senhor e que tirou da pedra mestra a solidez de seu poder e de seu nome; ele que, por revelação do Pai confessou que o mesmo é Filho de Deus e Cristo, porque admitir um dos dois sem o outro era inútil para a salvação e era igualmente perigoso acreditar que o Senhor Jesus Cristo era Deus somente sem o homem ou o homem somente sem Deus ${ }^{155}$.

Neste fragmento percebemos como o argumento salvífico norteia a reflexão de Leão Magno, articulando três noções, a saber: a divindade de Cristo, a sua humanidade, e a união das duas naturezas em uma mesma pessoa. Percebemos também que Leão Magno não elabora um meio termo entre a escola alexandrina e antioquena, mas se mantém fiel à tradição latina, e, em sintonia com o ensinamento do concilio de Éfeso, se distancia tanto de Nestório quanto de Êutiques. A clareza de sua terminologia há de aplacar as questões levantadas pelos antioquenos a respeito da união das naturezas de Cristo, e por isso seu papel será decisivo no Concílio de Calcedônia ${ }^{156}$.

Leão, ao tratar da dualidade de naturezas, avança na compreensão das mesmas afirmando que as propriedades de cada uma permanecem após a união, inclusive as operações que eram próprias de cada natureza, ou seja, "O Verbo realiza o que é do Verbo e a carne realiza o que é da carne"157. Esta formulação é ainda imperfeita porque está baseada no esquema Logos-sarx, pois, ao invés de indicar propriamente a natureza divina como princípio oposto à "carne", fala do Verbo, que indica a pessoa ${ }^{158}$.

\footnotetext{
153 Tome à Flavien, COD II-1, p.187 Apud SESBOÜÉ, B. História dos Dogmas., p.342.

${ }^{154}$ SESBOÜÉ, B. Op.cit., p.342.

155 Tome à Flavien, COD II-1, p.187 Apud SESBOÜÉ, B. Op.cit., p.343.

156 SESBOÜÉ, B. Op.cit., p.343.

157 Tomus ad Flavianum, Cap.4: DS, n. 294.

${ }^{158}$ GALOT, J. Chi sei tu, o Cristo?, p.232, inclusive a nota 76.
} 
O Pontífice, referindo-se no Tomus a Tertuliano, havia afirmado que existe "una persona in utraque natura"159. Desde então, o termo persona foi usado exclusivamente para significar o sujeito em Cristo. Daí para diante, a doutrina da lgreja consolidou a compreensão de que o princípio de unidade das duas naturezas não é a natureza divina, mas a segunda Pessoa divina. A união é estritamente hipostática, ou seja, não existe uma comunicação da natureza divina e das suas propriedades à humanidade de Cristo, mas só uma comunicação do "ser" da Pessoa, da subsistência"160.

A compreensão de natureza humana íntegra supõe que esta seja subsistente, ou seja, pertencente a si mesma, mas, em Cristo a natureza humana pertence ao Verbo eterno, e por isso perde a sua autonomia frente a um princípio divino mais alto. Isto significa que quando perde a sua subsistência simplesmente humana, a mesmaé assumida e sustentada por uma subsistência muito mais alta, pela própria subsistência divina ${ }^{161}$.

Portanto, podemos então concluir que foi a partir de seu vocabulário admiravelmente preciso que São Leão Magno contribuiu decisivamente para que a lgreja pudesse expressar a respeito da união das duas naturezas em Cristo, que Ele é uma mesma pessoa, que as duas naturezas continuam existindo sem mistura alguma, e que a unidade da pessoa permite a "comunicação dos idiomas", pois entende a pessoa do Verbo o sujeito único final de atribuição, e não a natureza, como queria Cirilo. Assim, é mérito de Leão Magno, esclarecer que a união do divino e do humano se dá na pessoa de Cristo, e não na natureza, seja a humana, assumida na encarnação, seja a divina, compartilhada com o Pai e o Espírito Santo.

No Tomus, Leão Magno ainda julgou Êutiques de docetista. Nesta obra ele desenvolveu a doutrina latina da "dupla consubstancialidade", como ficou mais tarde conhecida. Em conexão com o Símbolo Batismal, Leão mostra que o Cristo é gerado por Deus e por Maria, e que possui, portanto, uma natureza divina e uma natureza humana, tendo consequentemente propriedades e atividades divinas e humanas, sem as quais a unidade de sua pessoa ficaria posta em discussão ${ }^{162}$.

No entanto, devemos atentar bem para o fato de que para Leão as duas partes da noção de dupla consubstancialidade não devem ser entendidas simetricamente, pois o Pontífice compreende com toda clareza que a união de Cristo com o Pai era mais íntima que a união com os homens, e que as duas

\footnotetext{
159 Tomus ad Flavianum, Cap.3: DS, n. 293.

160 ADAM, K. O Cristo da fé., pp.46-47.

161 lbid., p.47.

162 STUDER, B. Dios Salvador en los Padres de la Iglesia., p.306.
} 
naturezas que fundamentam a dupla consubstancialidade não devem ser postas no mesmo plano. O duplo nascimento, proposto por Leão e depois presente na Fórmula de Calcedônia, mostra que Jesus Cristo deve ser confessado como verdadeiro Deus e verdadeiro homem ${ }^{163}$.

B. Studer propõe que o termo mais feliz para se traduzir consubstantialis poderia ser "solidário" termo que não só afirma a igualdade de naturezas, mas também a unidade na responsabilidade e nos fatos ${ }^{164}$.

$\mathrm{Na}$ linha de continuidade de uma longa tradição, Leão subdivide as afirmações soteriológicas em afirmações de Cristo enquanto Deus e as de Cristo enquanto homem. Neste sentido, como verdadeiro Deus, o Senhor realizou os seus milagres; como homem tomou sobre si os sofrimentos ${ }^{165}$. Segundo esta concepção, Cristo age no que corresponde ao divino pelo fato de estar em Deus, enquanto também age e sofre como humano pelo fato de ter se solidarizado totalmente com os homens.

Segundo Leão Magno somente Cristo como Deus poderia nos trazer a salvação, revelar-nos o Pai e vencer a morte e o pecado ${ }^{166}$. Devido à sua polêmica com os maniqueus, Leão expressa com grande clareza os pressupostos humanos de Cristo, pois só como homem ele podia anunciar Deus aos homens de maneira conveniente, dar-Ihes exemplos visíveis de virtude e, sobretudo, somente em sua descendência adâmica podia morrer ${ }^{167}$. A ressurreição também se situa na mesma perspectiva. Somente como homem Cristo podia vencer os horrores da morte e mostrar aos homens que também eles podiam esperar a glória ${ }^{168}$.

Enfim, seguindo a tradição latina, ao refutar a cristologia de Êutiques, Leão assinala com prodigiosa clareza a distinção das duas naturezas em Jesus Cristo $^{169}$, sem, contudo, macular a doutrina da unidade de Cristo. Suas explicações sobre o verdadeiro Deus e sobre o verdadeiro homem são sintetizadas no Tomus na unitas personae ${ }^{170}$. Quando mais tarde teve que defender tal doutrina da acusação de nestorianismo falava ainda com maior clareza sobre ela ${ }^{171}$. A confissão da unidade de pessoa que foi levada a cabo mediante a união das duas naturezas a partir da iniciativa do Filho de Deus ${ }^{172}$ tem

\footnotetext{
163 lbid.

164 lbid., nota 79.

165 Serm. 34,3; 28,3 Apud STUDER, B. Op.cit.

166 Serm. 25, 2s; Ep.59, 3 Apud STUDER, B. Op.cit.

167 Serm. 25, 2; 66,4;54, 4; 64, 2s Apud STUDER, B. Op.cit.

${ }^{168}$ Ep.59, 2s; Serm. 72, 2.5ss; 64, 2; 95,1 ; 67, 4; 39, 4 Apud STUDER, B. Op.cit.

169 Tomus ad Flavianum, Cap.2: DS, n. 290-292.

170 lb., cap.3: DS, n. 293.

171 Ep.124, 2 (Ep.165,2); Ep.129, 2 Apud STUDER, B. Dios Salvador en los Padres de la Iglesia., p.308.

172 Serm. 64, 2 Apud STUDER, B. Op.cit.
} 
para Leão capital importância soteriológica, pois a obra salvífica também pressupõe suas dimensões humanas, a saber: paixão e morte expiatória do Filho de Deus ${ }^{173}$. Mas também, Leão considerava ainda mais a unidade pessoal como fundamento da mediação de Cristo ${ }^{174}$. Com efeito, embora sintetize a união das duas naturezas, Leão assinala claramente que o homem Jesus pôde acolher com plena liberdade e obediência a morte redentora precisamente porque ele era Deus e homem ${ }^{175}$. De maneira que somente o Filho de Deus, que assumiu nossa humanidade sem deixar de ser Deus, podia realizar tudo isto ${ }^{176}$.

\section{3 \\ O concílio de Calcedônia}

Não é de nossa intenção percorrer aqui todos os pontos do concilio, mas apenas revelar brevemente aqueles que servem melhor para pôr em claro a verdade definida em Calcedônia naqueles dias de outubro de 451 no oratório da Basílica de Santa Eufêmia, onde se reuniram os padres conciliares, dentre os quais estavam os legados romanos Pascasino e Lucêncio, presidente segundo vontade expressa de Leão, e ainda os orientais, cuja representação é de grande importância, visto que muitos deles participaram do Latrocínio de Éfeso em 449, precisamente Dióscoro de Alexandria e Juvenal de Jerusalém. Ainda estavam presentes dois bispos africanos fugidos dos vândalos ${ }^{177}$.

Eis que agora as conjunturas eram diferentes daquelas presentes em Éfeso, haja vista que Roma já não apoiava mais Alexandria, mas sim Constantinopla e Antioquia. Agora, com o beneplácito imperial, a primeira preocupação do concílio é corrigir os erros do Latrocínio de Éfeso. Assim, são lidas as atas do sínodo de Constantinopla de 448, no qual Êutiques era condenado, em seguida também as atas de Éfeso de 449. Ainda foram lidas a segunda carta de Cirilo a nestório e o Ato de União de 433. Os prelados que participaram do Latrocínio procuraram justificar-se. Porém, ao final desta primeira parte dos trabalhos, Flaviano fora reabilitado e Dióscoro deposto, assim como Juvenal de Jerusalém e outros prelados de inclinação monofisita.

$\mathrm{Na}$ terceira sessão, em um clima mais tranquilo e tom mais doutrinal, fez-se a leitura do símbolo de Nicéia de 325 e o de Constantinopla de 381; segue-se logo

\footnotetext{
173 Serm. 64, 2; 95, 1; 67, 5; 39, 4 Apud STUDER, B. Op.cit.

174 Serm. 69, 5; 64, 3; Ep.35, 3 Apud STUDER, B. Op.cit.

175 Serm. 54, 1: sobre as diversas atividades das duas naturezas; Serm. 67, 2s: sobre as causas da morte de risto Apud STUDER, B. Op.cit.

176 Serm. 22, 2; 23, 2; 64, 3; 70, 3; 91, 2 Apud STUDER, B. Op.cit., p.309.

177 SESBOÜÉ, B. História dos Dogmas., p.343.
} 
a análise das duas cartas de Cirilo, já lidas na primeira sessão (uma a Nestório e outra a João de Antioquia, precisamente aquela que continha o Ato de União, e não os anatemismos); e por fim a leitura do Tomus ad Flavianum, aclamado como documento de fé.

Esta é a fé dos Padres. Esta é a fé dos apóstolos. Todos nós cremos assim! Nós ortodoxos, cremos assim! Anátema a quem não crê assim! Foi Pedro que, por Leão, disse essas coisas. Os apóstolos ensinaram assim. Leão ensinou piedosamente e com verdade. Cirilo ensinou assim. Eterna memória de Cirilo! Leão e Cirilo deram os mesmos ensinamentos. Anátema a quem não crê assim! Essa é a verdadeira fé178.

Os bispos confessaram todos unanimemente que o documento do Pontífice Romano concordava plenamente com as verdades definidas nos símbolos niceno e constantinipolitano. Contudo, temos aqui um problema de vocabulário. Pois mesmo sem querer contrapor Cirilo e Leão, ambos possuem um vocabulário claramente distinto, porém são intérpretes da reta doutrina defendida em Nicéia. Mas alguns prelados egípcios não se deixaram persuadir quando Leão falava em duas naturezas.

$\mathrm{Na}$ quarta sessão os representantes imperiais solicitaram que fosse redigido novo símbolo de fé, mas alguns bispos ainda rejeitavam a linguagem de Leão e só queriam consentir na fórmula das duas naturezas antes da união. Então, Pascasino, legado pontifício do sagrado concílio, julgando o parecer comum da maioria, respondeu que um novo símbolo de fé não se fazia necessário, pois os símbolos de fé e cânones já recebidos pela lgreja eram suficientes (os símbolos niceno e constinopolitano e as declarações de Cirilo no concílio de Éfeso), tendo, todavia, preeminência entre eles, na causa em questão, o Tomus ad Flavianum, visto que este condenava as heresias de Nestório e Êutiques, assim manifestando a reta doutrina transmitida pelos apóstolos, abraçada pelo santo sínodo e seguida pela lgreja ${ }^{179}$.

Entretanto, na quinta sessão do concílio, devido aos insistentes pedidos dos representantes de Marciano e do senado, foi formulada nova profissão de fé por um conselho constituído por prelados de diferentes regiões, que haviam se reunido no oratório da basílica de Santa Eufêmia. O novo símbolo é um verdadeiro florilégio das expressões dos diferentes parceiros do conflito desde o ano 428, passando pela segunda carta de Cirilo a Nestório, pelo Ato de União de 433, pelo Tomus ad Flavianum e, por fim, pela profissão de fé de Flaviano emitida por

\footnotetext{
${ }^{178}$ FESTUGIÈRE, A. J. Actes du Concile de Chalcédoine, p.37 Apud STUDER, B. Op.cit., p.344.
} 179 SR, n. 19. 
ocasião do sínodo de Constantinopla de 448 que condenara Êutiques ${ }^{180}$. Sendo assim, a definição constava dos símbolos niceno e constinopolitano e ainda da solene condenação da doutrina de Êutiques. Tal regra de fé foi aprovada unanimemente pelos padres conciliares.

\title{
3.4
}

\section{A definição de Calcedônia}

A solene definição de Calcedônia, haurida do Evangelho e em perfeita concordância com a tradição apostólica, ao afirmar duas distintas naturezas em Cristo na unidade de pessoa, condena o pensamento de Êutiques e Nestório, sem, contudo, contradizer Éfeso. Sua estrutura é composta basicamente das seguintes partes: uma introdução que justifica a nova definição, o Símbolo Niceno, a aprovação das cartas de Cirilo e do Tomus, a Fórmula de Calcedônia e um anátema contra todos os que pretendam ensinar outra fé diferente daquela do sagrado concílio. Para não nos alongarmos demasiada e desnecessariamente, nos limitaremos a examinar somente a Fórmula ou Definição de Calcedônia propriamente dita, o que corresponde exatamente ao nosso objetivo.

\begin{abstract}
Seguindo, pois, os santos Padres, com unanimidade ensinamos que se confesse que um só e o mesmo Filho, o Senhor nosso Jesus Cristo, perfeito na sua divindade e perfeito na sua humanidade, verdadeiro Deus e verdadeiro homem <composto> de alma racional e de corpo, consubstancial ao Pai segundo a divindade e consubstancial a nós segundo a humanidade, semelhante em tudo a nós, menos no pecado [cf. $\mathrm{Hb} 4,15]$, gerado do Pai antes dos séculos segundo a divindade e, nestes últimos dias, em prol de nós e de nossa salvação, <gerado> de Maria, a virgem, a Deípara, segundo a humanidade; um só e o mesmo Cristo, Filho, Senhor, unigênito, reconhecido em duas naturezas, sem confusão, sem mudança, sem divisão, sem separação, não sendo de modo algum anulada a diferença das naturezas por causa da sua união, mas, pelo contrário, salvaguardada a propriedade de cada uma das naturezas e concorrendo numa só pessoa e numa só hipóstase; não dividido ou separado em duas pessoas, mas um único e o mesmo Filho, unigênito, Deus Verbo, o Senhor Jesus Cristo, como anteriormente nos ensinaram a respeito dele os Profetas, e também o mesmo Jesus Cristo, e como nos transmitiu o Símbolo dos Padres ${ }^{181 .}$
\end{abstract}

Como bem se pode perceber, a definição do sagrado concílio de Calcedônia lança mão de termos soberbamente apropriados, com a exclusão de qualquer sombra de ambigüidade. Aqui se atribui uma mesma significação aos termos prósopon e hypóstasis, distinguindo-se ambos, porém, de physis.

Neste sentido, àqueles que como os antigos nestorianos e eutiquianos hoje pensam que o concilio de Calcedônia corrige o que fora definido em Éfeso, devem

180 SESBOÜÉ, B. História dos Dogmas., p.344.

${ }^{181}$ CONC. DE CALCEDÔNIA. Symbolum Chalcedonense Apud DS, n. 301. 
se compreender equivocados, visto que ambos mutuamente se completam; e são vigorosa e claramente confirmados no segundo e terceiros concílios ecumênicos de Constantinopla.

O texto da definição é redigido em tom solene de uma confissão de fé. Todavia, tão bem elaborado e com uma linguagem tão técnica e articulada que não seria conveniente se tornar um Símbolo litúrgico. Sua expressão mais significativa e característica é ensinamos que se confesse, o que muda o usual costume de se optar pelo verbo cremos que geralmente comanda o texto dos demais Símbolos, de modo que no Símbolo de Calcedônia o ponto de vista do ensinamento doutrinal ultrapassa o da simples confissão. Neste sentido, o conjunto da obra remete a tradição de fé que vem dos ensinamentos dos profetas, de Jesus Cristo e da tradição apostólica.

Porém, para procedermos com ordem, consideremos em princípio uma meticulosa leitura do texto da Fórmula. Pois uma leitura mais atenta da Fórmula de Calcedônia nos permite perceber nela a maturidade da Cristologia da Igreja antiga, a partir das contribuições - e concessões - das Escolas de Alexandria e Antioquia, bem como a lucidez da teologia ocidental. Assim, destrincharemos e examinaremos parte a parte a referida fórmula.

1 - "Seguindo, pois, os Santos Padres: a referência aos "Santos Padres" significa os participantes dos três Concílios precedentes, e mostraque é a tradição a fonte da presente definição ${ }^{182}$;

2 - com unanimidade ensinamos: a afirmação de que os Padres de Calcedônia unanimemente ensinam e confessam o que se dirá em seguida, tratase de um "recurso de autoridade" a fim de se bter o consenso de fé dos crentes ${ }^{183}$;

3 - que se confesse que um só e o mesmo Filho: a expressão "um e o mesmo", que ocorre na Fórmula por mais de uma vez, que remonta a Irineu, e está presente em Atanásio, nas Cartas de Cirilo II, Carta a Nestório e a Carta a João de Antioquia, e no Tomus, articula toda a Fórmula, é uma expressão pela qual os alexandrinos sempre brigaram ${ }^{184}$, mas que contém um sentido profundo que concilia a cristologia das duas Escolas orientais ${ }^{185}$, como será visto na seção seguinte. É a afirmação da unidade de sujeito em Cristo, da qual fazem referência imediatamente após as perfeições da divindade e da humanidade ${ }^{186}$, de modo que

\footnotetext{
182 AMATO, A. Gesù il Signore., p.296.

183 Ibid.

${ }^{184}$ SMULDERS, P. Evolução da Cristologia na Hitória dos Dogmas e no Magistério Eclesiástico., p.73s.

185 COM. TEOL. INT. Problemática Moderna da Cristologia., p.12.

${ }^{186}$ AMATO, A. Op.cit., p.269.
} 
o concílio sublinha que Cristo é um só e mesmo subsistente como Deus e como homem;

4 - o Senhor Nosso Jesus Cristo: sujeito no qual se articulam as proposições desta Fórmula;

5 - é o mesmoperfeito na sua divindade (refutação ao arianismo) e o mesmo perfeito na sua humanidade (refutação ao docetismo, ao arianismo, ao origenismo alexandrino, que gerou o monofisismo de corte apolinarista e o de corte eutiquiano): a partir daqui temos a distinção e a análise dos dois aspectos divino e humano do único Cristo. O sagrado concílio retoma o texto do Ato de União de 433, que fora aclamado por conter em si a expressão tradicional verdadeiramente Deus e verdadeiramente homem, presente na carta de Cirilo a João de Antioquia $^{187}$.

7 - verdadeiro Deus e verdadeiro homem: confissão de maneira paralela da plenitude de cada uma das duas naturezas de Cristo;

8 - composto de alma racional e de corpo: confissão da plena humanidade de Cristo, que compreende uma alma racional, ao contrário do que sugeria Apolinário, e um corpo;

9 - consubstancial ao Pai segundo a divindade, e consubstancial a nós segundo a humanidade: temos aqui a doutrina da dupla consubstancialidade, presente no Tomus e que satisfazia as questões levantadas pelos antioquenos. $\mathrm{O}$ uso do termo-chave do concílio de Nicéia é intencional e é ampliado no caso da humanidade. Entretanto, esta consubstancialidade não é exatamente da mesma ordem nos dois casos, haja vista que o Filho é consubstancial ao Pai num sentido numérico (unidade concreta da natureza divina) e consubstancial a nós homens num sentido específico. Uma dupla consubstancialidade na qual a primeira é eterna e a segunda é temporal;

10 - semelhante em tudo a nós, menos no pecado: esta é uma referência a $H b 4,15$ pela qual se afirma que o pecado não faz parte da natureza humana, mas de uma mancha, da qual Cristo não tomou parte;

11 - gerado do Pai antes dos séculos segundo a divindade: confessa a preexistência de Cristo, isto é, a sua geração eterna;

12 - nestes últimos dias: remete ao momento da encarnação na história da salvação, a qual incide na história dos homens;

13 - em prol de nós e de nossa salvação: expressão do Símbolo Niceno e que reflete a preocupação soteriológica do calcedoniano;

${ }^{187}$ SESBOÜÉ, B. História dos Dogmas., p.348. 
14 - gerado de Maria, a virgem, a Deípara, segundo a humanidade: ocorrência do termo Theotókos, que desde o Ato de União é aceito por todas as Escolas;

15 - um só e o mesmo Cristo, Filho, Senhor, unigênito, reconhecido em duas naturezas: é uma velha fórmula latina, e era também doutrina dos antioquenos ${ }^{188}$. A repetição intencional da expressão $o$ mesmo manifesta que as distinções entre as naturezas divina e humana não divide Cristo em dois seres. Até aqui o Símbolo de Calcedônia se dedicou a uma recapitulação de ensinamentos anteriores;

16 - sem confusão, sem mudança, sem divisão, sem separação: estes quatro advérbios negativos assinalam a compreensão e novamente a distinção das naturezas e refutam, os dois primeiros, o eutiquianismo, e, os dois seguintes, o nestorianismo;

17 - a diferença das naturezas por causa da sua união: esta noção ocorre na // Carta de Cirilo a Nestório e no Tomus, e quer assinalar que as naturezas permanecem após a união hipostática, a fim de refutar a doutrina de Êutiques;

18 - pelo contrário, salvaguardada a propriedade de cada uma das naturezas: esta noção, presente em Tertuliano, Cirilo e Leão, assinala a noção de "comunicação de idiomas", e quer refutar a doutrina de Êutiques, que considerava a assimilação das naturezas no nível de suas propriedades. Porém, estas não se misturam e cada umaguarda as características que fazem delas algo de particular e de exclusivo. A articulação desta afirmação com a fórmula precedente de origem ciriliana não sendo de modo algum anulada a diferença das naturezas por causa da sua união tem por objetivo mostrar o acordo entre Cirilo e Leão ${ }^{189}$.

19 - e concorrendo numa só pessoa e numa só hipóstase: os orientais traduziam o termo latino persona por prosopon; o acréscimo do termo hipóstase se dá por Flaviano, que o menciona em sua carta a Leão. Mas foi Cirilo o primeiro a insistir na necessária unidade de hipóstase em Cristo. É nele que a referida menção encontra sua origem. Com o termo hipóstase é possível precisar melhor para os orientais a noção de pessoa divina, e assim se completam os limites do termo prosopon. De modo que a distinção entre natureza e hipóstase é claramente estabelecida, malgrado não seja ainda especulativamente explicada.

20 - não dividido ou separado em duas pessoas: a fórmula em duas naturezas, faz eco à doutrina de Leão e foi adotada, até mesmo imposta, contra aqueles que queriam conservar a fórmula de duas naturezas, cuja insuficiência foi

188 SMULDERS, P.Evolução da Cristologia na História dos Dogmas e no Magistério Eclesiástico., p.74.

${ }^{189}$ SESBOÜÉ, B. Op.cit., p.349. 
mostrada pela postura de Êutiques. Tal opção claramente diofisita terá sérias consequências para a futura resistência à definição de Calcedônia.

21 - mas um único e o mesmo Filho, unigênito, Deus Verbo, o Senhor Jesus Cristo: temos aqui a identificação de Jesus Cristo com o Verbo divino;

22 - como anteriormente nos ensinaram a respeito dele os Profetas, e também o mesmo Jesus Cristo, e como nos transmitiu o Símbolo dos Padres: este último fragmento assinala a continuidade entre a Escritura e as fórmulas conciliares.

\section{5}

\section{A cristologia da Fórmula de Calcedônia}

A primeira observação que deve ser feita a respeito da Cristologia da Fórmula de Calcedônia é sobre a complementaridade existente entre os Concílios de Éfeso e Calcedônia. Ambos versaram sobre a Cristologia, cada qual com seu acento, ora a divindade, ora a humanidade de Cristo. Mas Calcedônia não apenas completa a perspectiva traçada por Éfeso como a equilibra, além de expressar a maturidade da Cristologia de então, pois na referida Fórmula estão presentes, como se viu na seção anterior, as contribuições das Escolas de Alexandria e de Antioquia, bem como a contribuição da teologia latina. Não se trata de uma Fórmula de fé distinta ou mais completa que a dos Concílios de Nicéia e Constantinopla, mas um esclarecimento, uma exposição cristológica frente às discussões daquele período ${ }^{190}$. Apesar das controvérsias relativas à recepção da Fórmula de Calcedônia, ela se tornou, especialmente no ocidente, a expressão típica da compreensão de fé cristã da lgreja ${ }^{191}$.

Calcedônia quer ser uma interpretação de Nicéia e colocar-se na sucessão do Niceno como puramente kerigmático. É por este motivo que o Símbolo de Nicéia abre os documentos do Concílio de Calcedônia. A Fórmula de Calcedônia é, assim, uma confirmação e uma interpretação de Nicéia. Diante da questão da encarnação posta pelos nestorianos e eutiquianos, o Concílio de Calcedônia elaborou um esquema fundamental da doutrina nicena, adotando expressões parafrásicas, como se lê na primeira parte da definição ${ }^{192}$.

Esta complementaridade se deu na trabalhosa tentativa de conciliar o "difisismo" antioqueno com o "monofisismo" alexandrino. Apesar desta complementaridade e equilibrio, é verdade que nem nestorianos e nem

\footnotetext{
190 lbid., p.100.

${ }^{191}$ AMATO, A. Gesù il Signore., p.300.

192 GRILLMEIER, A. Gesù il Cristo nella fede della Chiesa., p.972.
} 
alexandrinos radicais se identificam com esta Fórmula. Estes grupos têm parcela da verdade ao expressar e professar o mistério de Cristo, mas o Concilio e a sua Fórmula não foram capazes de satisfazê-los, apesar da Fórmula de Calcedônia expressar com clareza a unidade e a distinção em Cristo. Permanece atual esta questão, ao se abordar o desafio ecumênico suscitado pela Cristologia calcedoniana.

Há, portanto, um adequado equilíbrio entre as afirmações relativas à unidade e à dualidade em Cristo, de forma que o princípio da unidade é a pessoa, e o princípio da dualidade e da distinção é a natureza ${ }^{193}$. Este equilíbrio foi conseguido com o avanço ocorrido no sínodo de Constantinopla de 448, no qual se tentou superar a sinonímia, como faziam os alexandrinos, entre os termos physis e hipóstase, procurando-se a unidade no nível da sua subsistência e da sua pessoa (hipóstase), e a sua dualidade no nível da sua natureza (physis). Desta forma os Padres conciliares afirmavam explicitamente o que possuem de continuidade e convergência entre os pronunciamentos conciliares, o kerigma bíblico e tradição eclesial' ${ }^{194}$.

Neste contexto, o número "dois" não significa uma simples soma entre natureza divina e natureza humana, mas a irredutibilidade da natureza humana nos confrontos com a natureza divina. Trata-se de salvaguardar em Cristo tanto a dimensão divina, quanto à humana. Recorrendo à linguagem das duas naturezas evita-se a dissolução da humanidade na divindade e vice-versa ${ }^{195}$.

A expressão "um e o mesmo", de origem alexandrina, possui na Fórmula calcedoniana um significado profundo e conciliador das partes em tergiversação. Durante as controvérsias entre as Escolas de Alexandria e Antioquia nota-se a dificuldade de se conciliar a transcendência, ou seja, a distinção de naturezas, e a imanência, ou a união hipostática.

O Concílio de Calcedônia quis mostrar que é possível uma síntese dos dois pontos de vista recorrendo simultâneamente a duas expressões: "sem confusão" (asygkytos) e "sem divisão" (adiaitetos): aqui se pode ver o equivalente apofático da fórmula que afirma "as duas naturezas e a única hipóstase" do Cristo. "Sem confusão" se refere às duas naturezas e afirma a autêntica hipóstase do Cristo.

Ao mesmo tempo a fórmula remete à transcendência de Deus segundo o desejo dos anti-arianos enquanto afirma que Deus permanece Deus e o homem permanece homem. Esta fórmula exclui qualquer estado intermediário entre a

\footnotetext{
${ }^{193}$ AMATO, A. Op.cit., p.299.

194 Ibid.

195 lbid., p.301.
} 
divindade e a humanidade. "Sem divisão" proclama a união profundíssima e irreversível de Deus e do homem na pessoa do Verbo. Ao mesmo tempo é afirmada a plena imanência de Deus no mundo, a qual fundamenta a salvação cristã e a divinização do homem. Com estas afirmações os Padres conciliares atingiram um nível novo na percepção da transcendência. Esta não é apenas teológica, mas também cristã. Não se trata apenas da transcendência infinita de Deus ao homem, mas da transcendência infinita de Cristo, Deus e homem, com relação à universalidade dos homens e da história. Para os Padres conciliares o caráter absoluto e universal da fé cristã reside neste segundo aspecto da transcendência, que é ao mesmo tempo escatológico e ontológico.

O Concílio de Calcedônia não pretendeu dar uma resposta exaustiva à questão de como em Cristo podem coexistir Deus e homem. O Concílio traçou um espaço de significação do qual não se pode afastar. No interior deste espaço o Concílio colocou "um" e "outro" que pareciam excluir-se, a transcendência e a imanência, Deus e homem. Os dois aspectos devem ser afirmados sem restrição, mas excluídos de toda justaposição e mistura. Assim, no Cristo, a transcedência e a imanência estão perfeitamente unidas ${ }^{196}$.

O concílio de Calcedônia, com um objetivo claramente apologético, se distingue pela nitidez e eficácia em combater o erro usando termos muito apropriados, com a exclusão de toda ambiguidade. Com efeito, a definição de Calcedônia atribui a mesma significação aos termos pessoa e hipóstase (prósopon e hypóstasis). Já ao termo natureza (physis) dá um sentido diverso, e nunca se usa com a significação dos dois primeiros.

Neste sentido, estavam equivocados os nestorianos e eutiquianos, bem como alguns historiadores hodiernos, ao opinarem que o concílio de Calcedônia tenha corrigido o que fora definido no de Éfeso. Ao contrário, ambos mutuamente se complementam. E é mesmo nos posteriores segundo e terceiro concílios ecumênicos de Constantinopla, que a síntese da fundamental doutrina cristológica aparece mais vigorosa e clara ${ }^{197}$.

Alguns monofisitas, partindo da equivocada compreensão de algumas expressões antigas rejeitaram a definição de Calcedônia. Apesar de se oporem a Êutiques, que falava de uma mistura das naturezas em Cristo, aferraram-se à locução: Uma natureza encarnada do Deus Verbo, que Cirilo de Alexandria usou como proveniente de Atanásio, compreendendo-a, porém, no reto sentido, pois transportava a significação de natureza para pessoa. Os Padres conciliares

\footnotetext{
${ }^{196}$ COMISSÃO TEOLÓGICA INTERNACIONAL, Cuestiones selectas de cristología.
} ${ }^{197} \mathrm{SR}, \mathrm{n} .27$. 
excluíram o que havia de ambíguo ou incerto naqueles termos, equiparando a terminologia trinitária com a utilizada para exprimir a encarnação do verbo, identificando natureza e ousía, como identificaram pessoa e hipóstase, e julgaram que os dois primeiros termos devem ser compreendidos absolutamente de maneira distinta dos dois segundos, ao passo que os dissidentes equipararam natureza à pessoa, mas não à ousía. Com efeito, deve-se professar, numa linguagem comum e livre de ambiguidades, que em Deus há uma só natureza e três pessoas, em Cristo há uma pessoa e duas naturezas ${ }^{198}$.

Atualmente, algumas comunidades do Egito, Etiópia, Síria, Armênia e outras localidades, parecem afastar-se da maneira exata de exprimir a doutrina do mistério da encarnação a partir de uma terminologia adequada, como se pode perceber em seus livros litúrgicos e teológicos ${ }^{199}$.

Outrossim, vai de encontro à definição do sagrado Concílio de Calcedônia a chamada doutrina "kenótica", que a partir de uma interpretação equivocada e arbitrária de FI 2,7 chega a despojar Cristo da divindade do Verbo, reduzindo, assim, todo o mistério da encarnação e redenção. Ao passo que Leão ensina: "O verdadeiro Deus nasceu em íntegra e perfeita natureza de verdadeiro homem; perfeito quanto ao que é seu, e perfeito quanto ao que é nosso"200.

É bem verdade que a humanidade de Cristo deve ser mais profundamente estudada também sob o aspecto psicológico. Contudo, muitos que se enveredam por estas investigações tão sutis, acabam por abandonar as normas mais antigas e constroem teorias usando indevidamente para o sustento das mesmas a autoridade do Concílio de Calcedônia.

Esses tais descrevem a natureza humana de Cristo de tal forma que parece conceber-se como um sujeito de per si, como se não subsistisse na pessoa do Verbo. Malgrado o concílio de Calcedônia, plenamente de acordo com o de Éfeso, declarar com admirável clareza que ambas as naturezas do nosso Redentor estão unidas em uma só e mesma pessoa e proibir pôr em Cristo dois indivíduos, de modo que se coloque junto ao Verbo um como "homem assumido", dotado de inteira autonomia própria.

\footnotetext{
${ }^{198}$ SR, n. 28.

199 lbid.

200 LEÃO M., Ep.28,3: PL 54, 763. Cf. Serm. 23,2: PL 54, 201 Apud SR, n. 32.
} 


\section{6 \\ A recepção imediata no Ocidente e Oriente}

Pouco mais de um século separa os concílios de Calcedônia (451) e Constantinopla II (553), um período de lutas violentas no Oriente em torno da recepção da definição cristológica de um concílio considerado "maldito" 201 por alguns. Uma história cheia de pormenores que reflete a dificuldade de se aceitar a cristologia aí solenemente definida. Assim como em Nicéia, o Concílio de Calcedônia, convocado para resolver uma questão doutrinal, acaba por provocar um cisma de linguagem tanto entre heréticos e ortodoxos, quanto entre os próprios ortodoxos que, desejando permanecer fiéis à fé, têm dificuldades para encontrar a linguagem comum ou apropriada para expressar a mesma fé em fórmulas dogmáticas. Com efeito, haverá controvérsias contra "as duas naturezas", assim como houve em torno do "consubstancial". O preço que se paga por tudo isso é a unidade da Igreja, haja vista que o cisma de linguagem se expressa em Igrejas "cismáticas", cujas divisões são alimentadas por rivalidades políticas. Ainda em nossos dias muitos destes cismas não foram superados e a reconciliação ainda parece distante ${ }^{202}$.

Malgrado o concílio tratar de uma questão doutrinal, muitos imperadores interviram de perto na questão. Contudo, a primeira preocupação deles não era prioritariamente a fidelidade à fé, mas a unidade e a paz no império, visto que a paz religiosa neste contexto é primordial. Vários foram os editos dogmáticos emitidos pelos imperadores, mas todos eles terão sempre como alvo restabelecer a unidade no âmbito eclesiástico, considerado de suma importância. Com este mesmo intuito, muitos documentos foram promulgados, que vão desde a condenação de Calcedônia, como é o caso da Encíclica de Basilisco, ao seu abandono discreto através da Henótica, até a volta por cima em seu favor, um tanto instável com Atanásio, porém firme em Justino. Já no Ocidente a recepção foi espontânea e não causou problemas. No entanto, no Oriente a crise provocou um cisma de 33 anos entre as duas partes da lgreja. ${ }^{203}$

O Imperador Leão chegou até mesmo a organizar uma grande pesquisa de opinião entre os bispos a respeito do Concílio de Calcedônia, o que nos dá uma noção do grau de recepção do concílio no Oriente naquele tempo. As respostas evidenciaram a divisão de dois grupos em duas posições diversas: o primeiro

\footnotetext{
${ }^{201}$ Muitas Igrejas do Oriente que permaneceram fiéis à linguagem de Cirilo consideraram-no como o "concílio maldito". Situação semelhante ao que se sucedeu nos cinquenta anos seguintes ao Concílio de Nicéia. Cf. SESBOÜÉ, B. História dos Dogmas. p.146.

$202 \mathrm{lbid}$

${ }^{203}$ Id. O magistério em questão., p.95.
} 
grupo considerava Calcedônia como uma mera confirmação do que já fora definido em Nicéia; ao passo que o segundo grupo estava mais atento à autoridade própria de Calcedônia em razão da assistência divina de que foram revestidos os Padres de Calcedônia. Com efeito, passa-se de uma recepção relativa a uma recepção absoluta ${ }^{204}$.

Porém, o que chama a nossa atenção nesse conflito é o que se refere à linguagem. Pois se por um lado fala-se em uma sónatureza, em fidelidade a Cirilo, por outro lado fala-se em duas naturezas, em conformidade com a definição calcedoniana e com o Tomus do Papa Leão. Neste sentido, o conflito é, por assim dizer, um conflito de linguagem, visto que os monofisitas não aderiram à doutrina de Êutiques. E isso é bastante significativo no sentido de que constitui uma abertura para a reconciliação, haja vista que todos têm a ideia cristológica através de signos linguísticos diversos ${ }^{205}$.

Por fim, as intervenções imperiais não foram capazes de impedir o lento processo do reconhecimento majoritário da cristologia de Calcedônia. Com o passar dos séculos, entre muitos avanços e recuos, o Concilio foi trilhando o seu próprio caminho e sendo recebido pela maioria dos bispos, sucessores dos apóstolos e, por isso mesmo, considerados testemunhas da fé e da tradição apostólica que devem ser transmitidas ao seu povo com fidelidade. O Ocidente também teve o seu papel nessa recepção. Entretanto, a cristologia de Calcedônia ainda hoje suscita questões hermenêuticas de difícil solução. De modo que os cismas do passado provocados pela não recepção do concílio perduram ainda em nossos dias, apesar das constantes declarações conjuntas entre os últimos Romanos Pontífices e os patriarcas das chamadas igrejas pré-calcedonianas, é o caso, por exemplo, das Igrejas Copta, Armênia e Jacobita. 


\section{A Cristologia calcedoniana Católica}

Neste quarto capítulo da presente obra trataremos das abordagens atuais da Fórmula de Calcedônia no âmbito da cristologia católica, ou seja, da sua recepção hodierna entre os principais teólogos católicos, de modo que possamos assim considerar séria e profundamente as categorias cristológicas atuais a partir das perspectivas históricas às quais aludimos na introdução deste ensaio.

Antes mesmo de considerarmos os esboços cristológicos dos teólogos mais contemporâneos, sejam católicos, protestantes ou ortodoxos, é mister recordarmos que os primeiros questionamentos da Era Moderna a respeito da cristologia de Calcedônia surgiu com a Reforma Protestante, recebendo considerável impulso séculos mais tarde por Adolf Von Harnack, também em ambiente protestante. Mas é com o protestante Rudolf Bultmann e com o católico Karl Rahner, que nós encontramos as bases dos questionamentos mais contemporâneos pertinentes à fórmula de Calcedônia. Com efeito, para procedermos com ordem, a seguir visitaremos o contributo destes dois últimos grandes teólogos e somente em seguida nos debruçaremos sobre o esboço cristológico dos teólogos mais contemporâneos.

\section{1}

\section{Da Reforma Protestante a R. Bultmann e K. Rahner}

A história da teologia nos atesta as limitações próprias do tempo impostas à interpretação da cristologia calcedoniana. No presente ensaio, consideramos apenas os questionamentos surgidos a partir da Modernidade, visto que estes terão um considerável eco na Contemporaneidade.

A Modernidade, iniciada a partir da tomada de Constantinopla pelos turcos otomanos (1453), é palco do chamado "cisma do ocidente", isto é, a Reforma Protestante, que teve como grande pivô Martinho Lutero (+1546). A revolução do cristianismo por ele liderada tocou todas as realidades da vida eclesial: pastoral, estrutura hierárquica, espiritualidade, doutrina e teologia.

Lutero é o primeiro na Modernidade a levantar um significativo questionamento à cristologia calcedoniana: 
Cristo tem duas naturezas. O que isto significa para mim?... Ser, por natureza, homem e Deus é algo que diz respeito a ele mesmo... Crer em Cristo não significa que ele é uma pessoa, que é homem, que é Deus. Isto não é útil para ninguém. $O$ importante que essa pessoa é Cristo, ou seja, ele veio do Pai para nós, neste mundo. Dessa função é que vem o seu nome ${ }^{206}$.

Séculos depois, já em fins do século XIX, em ambientes protestantes, surge o impulso dado por Adolf Von Harnack, com o imperativo de des-helenizar a fé cristã, porém ele parece desconhecer o direito histórico dos Padres da lgreja de exprimir e conservar a fé cristã em categorias de então. Todavia, é a partir daí que começamos a perceber um maior interesse em colocar o tema cristológico no centro do debate teológico.

\subsection{1 \\ Rudolf Bultmann}

No século XX, o luterano Rudolf Bultmann (+1976) deu grande impulso à exegese, dotando-a de um instrumento de análise extremamente preciso para conhecer os Evangelhos e os contextos de vida em que nasceram e, assim, sistematizou o método da "história das formas" ou morfocrítico, primeiro passo para o desenvolvimento do método histórico-crítico. Contudo, desprovido de sólida formação doutrinal, Bultmann afirmou a rotura entre o Jesus histórico e o Cristo da fé ${ }^{207}$. Assim, o teólogo alemão tornou mais agudo e radical o questionamento de Lutero ao perguntar: "Ajuda-me porque é Filho de Deus ou é Filho de Deus porque me ajuda?"208.

Bultmann assinala desta forma a importância do kerigma ao qual o crente adere. Para Bultmann, o Jesus crucificado se encontra com o crente como o Ressuscitado na palavra da pregação, como pretensão imediata que o coloca diante da decisão de fé e o conclama para a autenticidade de sua existência, ou seja, para a vida na confiança na graça ${ }^{209}$. Tal abordagem do mistério de Cristo parece minimizar a evolução teológica, doutrinal e dogmática acerca do mesmo mistério.

A radicalidade de Bultmann o levou a conceber certos aspectos cristológicos da seguinte maneira: Jesus seria apenas um homem, o último dos profetas do Antigo Testamento; há uma rotura tão grande entre kerigma e história que não sabemos praticamente nada da vida e da personalidade de Jesus; os títulos de

\footnotetext{
${ }^{206}$ CONGAR, Y. Le Christ, Marie et l'Église, p.33 Apud DUPUIS, J. Introdução à Cristologia., p.130. 207 LATOURELLE, R. Bultmann, Rudolf., p.116.

${ }^{208}$ BULTMANN, R. Glauben und Verstehen, v. II, 1952 Apud DUPUIS, J. Op.cit., p.129.

209 KESSLER, H. Cristologia., p.338s.
} 
"filho de Deus", "Salvador" e "Senhor" foram a ele aplicados pela lgreja primitiva com o objetivo de fazer frente às divindades gregas; os milagres e a ressurreição são expressão da linguagem mítica do helenismo, do gnosticismo e da apocalíptica hebraica; por fim, Jesus não é o salvador da humanidade, nem redentor dos homens, mas simplesmente o lugar da historicidade escolhido por Deus para tornar conhecida aos homens a salvação mediante a fé210.

Tanta radicalidade, evidentemente sem negar os méritos de Bultmann, levou alguns dos seus discípulos a romper com o mestre, mostrando que os Sinóticos são, pelo menos em sua essência, fiéis sim aos fatos, malgrado reconheçam que a Igreja primitiva tenha remanejado ditos e narrações de Jesus ${ }^{211}$. Este processo gerou, no século XX, o método hitórico-crítico, que mais tarde foi assimilado pela Igreja Católica e pelo seu Magistério ${ }^{212}$.

A despeito de tanta radicalidade o Concílio de Calcedônia e a tradição pósconciliar não admitem cisão alguma entre o Cristo da fé e o Jesus da história, ou numa linguagem mais apropriada, entre a função de Jesus e o seu ser. Pois aquela não existe sem este. O ser de Jesus Cristo é, em si mesmo, o alicerce indispensável de sua ação salvífica em favor da humanidade. Ele pode ser o que é para nós, por ser quem é em si mesmo. Neste sentido, função e ontologia estão em uma relação indiscutivelmente interdependente. De modo que a tradição cristã e mais ainda a cristologia hodierna fazem uma abordagem cada vez mais ontológica da cristologia, repetindo o que ocorreu na lgreja apostólica, que sugeriu uma evolução da cristologia funcional do Kerigma primitivo para a cristologia ontológica dos escritos posteriores ${ }^{213}$.

Contudo, isto não significa que tal desenvolvimento, inclusive historicamente verificado, sobretudo em Calcedônia, seja desprovido de limites e imperfeições; muito pelo contrário, a própria história nos atesta os limites impostos pelo tempo, linguagem e cultura. Porém, mesmo diante destes desafios as questões e as respostas relativas à fórmula calcedoniana permanecem atuais ainda hoje. Atuais porque, contra os perigos sempre presentes do monofisismo, elas nos ajudam a manter a verdade e a humanidade de Jesus em união com o Filho de Deus. Em Cristo Jesus o homem se aproximou ao máximo de Deus como jamais se ouviu

\footnotetext{
${ }^{210}$ LATOURELLE, R. Op.cit., p.119.

211 TERRA, J.E.M. O Jesus Histórico e o Cristo querigmático., p.43.

212 PIO XII. Carta Encíclica Divino Afflante Spiritu (1943); VATICANO II. Constituição Dogmática sobre a Revelação Divina Dei Verbum (1965); PONTIFÍCIA COMISSÃO BÍBLICA. A Interpretação da Bíblia na Igreja (1993).

${ }^{213}$ DUPUIS, J. Introdução à Cristologia., p.130.
} 
falar na história das religiões. Mas isto não significa assimilação de sua humanidade pela divindade.

\title{
4.1.2 \\ Karl Rahner
}

O jesuíta Karl Rahner ${ }^{214}(+1984)$ mostra que o contrário é que de fato é verdadeiro, ou seja, a autenticidade e a realidade da humanidade de Jesus são diretamente proporcionais à sua união com Deus. Neste sentido, a humanidade de Jesus é realçada pela união, pois sua autonomia e proximidade de Deus crescem em proporção direta.

\begin{abstract}
Visto que na encarnação o Lógos cria aceitando e aceita manifestando a si mesmo, prevalece também aqui e em nível mais radical e especificamente único o axioma de toda a relação entre Deus e a criatura, a saber, que a vizinhança e a distância, o estar à disposição e a autonomia da criatura crescem em medida igual e não em medida inversa. Por isso, Cristo é homem no modo mais radical e sua humanidade é a mais autônoma, a mais live, não apesar, mas porque é humanidade aceita e colocada como auto manifestação de Deus ${ }^{215}$.
\end{abstract}

Rahner apresentou uma cristologia de enfoque transcendentalantropológico ${ }^{216}$, pela qual mostrou que o ser humano, a partir de sua estrutura de princípio (sujeito e auto transcendência), sempre procura pré-conscientemente aquilo que a mensagem cristã lhe proclama como o que apareceu na história concreta de Jesus Cristo, isto é, a auto comunicação de Deus e o portador da salvação. Jesus é a expressão do real amor de Deus, a auto comunicação radical de Deus aos seres humanos, que realiza a essência humana, que por sua vez realiza a humanidade verdadeira e a possibilita aos outros ${ }^{217}$.

A partir desta perspectiva se estabelece uma associação íntima entre a doutrina da encarnação e a concepção evolutiva do mundo, sem, contudo, que a

214 O movimento cristológico contemporâneo que surgiu a partir de 1951 com o jubileu de 1500 anos da definição de Calcedônia, que possibilitou uma série de novas pesquisas, encontrou em Karl Rahner grande motivador que em 1954 propôs um programa para a renovação da cristologia, onde ele suscita os principais temas que seriam objeto de investigação durante as décadas seguintes, tais como: a relação da cristologia clás sica com o tes temunho bíblico; a necessidade de completar a cris tologia ontológica com uma cris tologia exis tencial; uma interrogação apoiada sobre a definição de Calcedônia, considerada mais como um início do que como um fim; a necessidade para hoje de uma cristologia transcendental. Posteriormente, ele mesmo há de apresentar uma cristologia desenvolvida num horizonte antropológico e concederá amplo espaço à cristologia transcendental. ${ }^{215}$ RAHNER, K. Teologia dell'incarnazione., pp.115-116 Apud DUPUIS, J. Op.cit., p.131.

${ }^{216} \mathrm{O}$ método transcendental-antropológico de Rahner tem como ponto de partida o homem, como uma maneira de estabelecer uma relação entre a fé e a experiência cotidiana, histórica e concreta do homem. Por isso, então, é chamado de antropológico. O homem concebido como espírito no mundo (transcendentalidade e imanência histórica) é ouvinte da Palavra. Nele estão todas as condições de possibilidade para receber uma possível revelação histórica de Deus. Como espírto no mundo, o ser humano é abertura infinita a própria plenitude da graça. Cf. RAHNER, K. Curso Fundamental da fé., p.215; Id. Oyente de la Palabra., pp.89-90.

${ }^{217}$ KESSLER, H. Cristologia., p.339. 
encarnação seja considerada uma consequência da referida concepção evolutiva do mundo, mas pelo contrário, seja sim a plenitude da realização do homem e sua realidade evolutiva. Neste sentido, a encarnação constitui o ponto mais alto da abertura do homem a Deus, ou mais ainda, o momento do encontro mais íntimo entre a transcendência e a imanência. É assim que Rahner compreende a união hipostática, ou o mistério da encarnação, sob a ótica do método teológico transcendental, o que faz de sua cristologia também transcendental.

Com efeito, nesta lógica transcendental-antropológica, a encarnação constitui o grau mais elevado de realização da condição de possibilidade da abertura do homem a Deus. Trata-se da realização plena do transcendental em linha vertical, a partir da qual a criatura, por gratuidade divina, alcança a união íntima com o transcendente, ou seja, com Deus. Tal união íntima é considerada por Rahner a própria graça.

O Deus-homem é o início primeiro do êxito definitivo do movimento de autotranscendência do mundo para o interior da proximidade absoluta ao mistério de Deus. Essa união hipostática não se deverá considerar em primeiro lugar como algo que distingue Jesus de nós, os outros homens, mas antes como algo que deve ocorrer uma vez e somente uma vez ao começar o mundo a entrar em sua fase última (o que não quer dizer necessariamente a mais breve), na qual deve realizar sua concentração definitiva, atingindo seu ponto alto definitivo e sua radical proximidade ao mistério absoluto chamado Deus ${ }^{218}$.

A partir da cristologia rahneriana, dita transcendental, a união hipostática, mediante a encarnação do Verbo, inaugura por um lado o discurso da possibilidade do desenvolvimento de Deus no seu Verbo e por outro, constitui a realização histórica plena da união íntima do criador com a criatura, daquilo que para Rahner só se dá por um ato de gratuidade divina, ou seja, por um esquema descendente no qual se baseia a própria cristologia católica ${ }^{219}$.

Para Rahner, a encarnação do Lógos não constitui um simples travestimento no qual Deus se faz mais ou menos partícipe da realidade humana, como uma espécie de modalismo encarnatório ou monofisismo divino, pelo qual, a partir de um disfarce, aparece no mundo de um modo similar ou aparente. Na encarnação Deus torna-se homem em toda plenitude da expressão.

\footnotetext{
O dogma cristão da encarnação deverá, portanto, expressar o seguinte: Jesus é verdadeiramente homem com tudo o que isto comporta, com sua finitude, mundanidade, materialidade e com a sua participação na história deste nosso cosmos na dimensão do espírito e da liberdade, na história que atravessa a porta estreita da morte 220 .
}

\footnotetext{
${ }^{218}$ RAHNER, K. Curso Fundamental da fé., p.219.

219 lbid., 338 .

220 lbid., 237.
} 
Com efeito, é nesta íntima relação da cristologia como princípio e fim da antropologia - que por sua vez faz com que a esta última encontre a sua realização mais radical na primeira -, se fundamenta a possibilidade e necessidade do portador absoluto da salvação ${ }^{221}$. O ser humano imerso em sua cotidiana criaturalidade, na qual faz experiência de sua finitude, assim como também de sua abertura transcendente ao incriado, sente a necessidade de um portador absoluto da salvação no qual se realiza plena e intimamente a sua vocação última.

O axioma fundamental da teologia trinitária de Karl Rahner, segundo o qual a Trindade econômica é a Trindade imanente e vice-versa, oferece uma resposta a esta questão. Pois na encarnação se dá a auto manifestação livre, gratuita e kenótica do Deus absoluto e transcendente, que se oferece de modo radical a toda humanidade em sua mais profunda imanência histórica. É neste sentido que o cristianismo vê em Jesus Cristo a realização da esperança do portador absoluto da salvação.

$\mathrm{Na}$ teologia contemporânea, Rahner é um dos primeiros teólogos a testemunhar a importância da história no discurso teológico atual, e também a articulação deste com o patrimônio dogmático, em especial a Fórmula de Calcedônia.

\begin{abstract}
Temos, não somente o direito, mas o dever de compreender esta definição ao mesmo tempo como um ponto de chegada e como um ponto de partida. Precisaremos distanciar-nos daquela definição, não para abandoná-la, mas para compreendê-la, para penetrá-la com toda a nossa inteligência e todo o nosso coração, para, através dela, aproximar-nos o máximo do Indizível, do Deus sem nome, que quis que o procurássemos e o encontrássemos em Cristo Jesus e por Ele. Retornaremos sempre àquela fórmula porque, quando for preciso dizer sucintamente o que encontramos no inefável conhecimento que é a nossa salvação, será sempre na humilde e sóbria clareza da definição de Calcedônia que desembocaremos. Mas só desembocaremos verdadeiramente nela (o que é diferente de repeti-la), se ela for, para nós, não somente um ponto de chegada, mas também um ponto de partida ${ }^{222}$.
\end{abstract}

Tal postura nos remete ao direito e ao dever de uma interpretação sempre nova da fé cristológica nas categorias do presente, ou seja, na necessidade de exprimir de maneira sempre nova a Fórmula de Calcedônia, a partir da descoberta da historicidade de todas as asserções de fé ${ }^{223}$. A influência do pensamento

\footnotetext{
$221 \mathrm{lbid}$., 235: Rahner entende que este portador absoluto da salvação, que evidentemente é o Lógos encarnado, constitui o vértice da auto comunicação de Deus ao mundo, que deve ser ao mesmo tempo o apelo absoluto de Deus à criatura espiritual em seu conjunto e o acolhimento da auto comunicação, haja vista que de outra maneira a história jamais poderia chegar à sua irreversibilidade.

222 RAHNER, K. Problèmes actuels de christologie., p.117 Apud SCHILSON, A.; KASPER, W., Cristologia., p.15.

${ }^{223}$ GS, n. 42 e 62; UR, n. 46.
} 
histórico libertou a cristologia da repetição, o que implicava numa paralisia, e colocou em evidência a necessidade de uma renovação constante, isto é, de uma reflexão constante ${ }^{224}$.

A teologia de Rahner de fato concebe a fórmula dogmática de Calcedônia como normativa. O teólogo alemão não propõe uma cristologia que implica superação ou eliminação da referida fórmula calcedoniana, mas sim uma renovada compreensão da mesma, ou seja, uma compreensão sob a ótica dos elementos que constituem os fundamentos de sua cristologia transcendental, a saber: a necessidade de conceber a referida fórmula como um início e não como um fim, a possibilidade de Deus se tornar em outro, frente a sua imutabilidade; a condição de possibilidade do homem se abrir e acolher a possível revelação de Deus na história; em suma; a possibilidade de completar a cristologia ontológica com a cristologia existencial, que em última análise consiste na própria cristologia transcendental rahneriana, em que se insere a revelação de Deus na história do homem, na qual se manifesta a trindade imanente de maneira econômica; e a encarnação como a realização mais elevada da abertura do ser humano a Deus, ocorrida uma vez e uma só vez na auto comunicação de Deus em Jesus Cristo.

Rahner quer ultrapassar uma fé em Cristo puramente revelada em um sentido positivista e constantemente próxima da pura mitologia. Ele tenta aclarar internamente e justificar uma confissão de fé cristológica pela qual possamos hoje assumir a responsabilidade. É neste sentido que ele esboça uma cristologia transcendental.

A tarefa mais urgente de uma Cristologia de hoje consiste em formular o dogma da Igreja - Deus é (tornou-se) homem, e este Deus que se fez homem é o Jesus Cristo concreto - de modo a tornar compreensível o que estas proposições significam e em excluir toda aparência de uma mitologia que se tornou inaceitável hoje ${ }^{225}$.

A postura de Rahner nos chama a atenção porque consegue resgatar a cristologia do campo meramente nominal, que por sua vez conduz à absolutização ou mera repetição da fórmula calcedoniana, impulsionando-a à abertura antropológica do ser humano em sua relação com o Deus que se revela na encarnação. A união hipostática aí é vista não só no plano estritamente dogmático-formal, mas também a partir do plano existencial-antropológico da plena união do Criador com a criatura, união que constitui a realização última da criatura alcançada por Jesus Cristo, perfeito Deus e perfeito homem.

224 SCHILSON, A.; KASPER, W. Cristologia., p.15.

${ }^{225}$ RAHNER, K. Jesus Christus., p.927 Apud SCHILSON, A.; KASPER, W. Op.cit., p.73. 
Outrossim, há que se reconhecer que a elaboração de uma cristologia transcendental conduz não tanto ao questionamento da fórmula dogmática de Calcedônia, mas principalmente ao questionamento da cristologia clássica ou escolástica. Contudo, qualquer releitura da fórmula calcedoniana que tenda a libertá-la de suas categorias e condicionamentos temporais e/ou culturais, há de fazê-lo a partir de categorias e condicionamentos modernos que, evidentemente, não correspondem àqueles utilizados em 451.

Da mesma forma, a própria expressão "cristologia transcendental" não está livre de ambiguidades, mas significa basicamente o desejo de elucidar mais detalhadamente, através da antropologia, aquilo que torna intrinsecamente possíveis o aparecimento e a auto expressão de Deus em uma figura humana. Sendo assim, só podemos evitar que o dogma cristológico da lgreja caia em erros e contradições se considerarmos e reconhecermos a possibilidade que o homem tem de conciliar sem contradição Deus e homem no Homem-Deus Jesus Cristo. Contudo, é ainda mister mostrar, a partir de uma profunda reflexão antropológica, que o homem, no seu estado concreto, está à escuta de uma palavra de salvação encarnada e histórica de Deus e a deseja. Neste sentido, como já afirmamos anteriormente, 0 homem na sua mais profunda existência permanece constantemente orientado para um portador absoluto da salvação revestido de humanidade. Somente a partir daí é que podemos compreender o significado salvífico do evento histórico Jesus Cristo como consumação suprema da esperança e da aspiração humanas de todos os povos e de todos os tempos, e até mesmo como a única condição que permite ao ser do homem ter um sentido perfeito ${ }^{226}$.

\footnotetext{
O portador absoluto da salvação, ou seja, a irreversibilidade da história da liberdade como autocomunicação exitosa de Deus, é de início ele próprio por sua vez momento histórico do agir salvífico de Deus para com o mundo e de tal sorte que é ao mesmo tempo parcela da história do próprio cosmos. Ele não pode ser simplesmente o próprio Deus agindo no mundo, mas precisa ser parcela do mundo, momento em sua história e precisamente em seu clímax. É isso que se afirma no dogma cristológico: Jesus é verdadeiramente homem, verdadeiramente parcela da terra, verdadeiramente momento no devir biológico deste mundo, momento da história natural humana, pois "ele nasceu de uma mulher" (GI 4,4). Ele é um homem que, em sua subjetividade espiritual humana e finita, é, da mesma forma que nós, receptor da graciosa autocomunicação de Deus que afirmamos que está destinada a todos os homens e, portanto, também ao cosmos, como sendo o ponto mais alto da evolução, no qual o mundo chega de forma absoluta a si mesmo e à absoluta imediatez com referência a Deus ${ }^{227}$.
}

${ }^{226}$ SCHILSON, A.; KASPER, W. Op.cit., pp.73-74.

${ }^{227}$ RAHNER, K. Curso Fundamental da Fé., p.235. 
A teologia contemporânea tem acusado a definição dogmática calcedoniana de ter helenizado o anúncio salvífico do Novo Testamento com conceitos demasiadamente ontológicos que pouco dizem ao povo de nosso tempo. Uma das críticas ao pensamento de Rahner é o de ter antropologizado a teologia. É o caso de Von Balthasar, que em sua obra intitulada Só o amor é credível adverte os leitores contra os tipos de redução no meio teológico, a saber: a redução cósmica e a redução antropológica, em que a primeira resultaria limitada e encerrada nos parâmetros do tempo e da história, enquanto a segunda é igualmente falha e limitada porque aquele Deus que quer se fazer próximo do homem por Cristo não pode ser sistematizado nem a partir do mundo e nem a partir do homem ${ }^{228}$. Tratase, portanto, de um discurso teológico absoluto. Entretanto, uma leitura mais atenta da obra de Rahner nos leva a compreender que ele não quer fazer da teologia uma redução antropológica baseada na mera abertura transcendental do homem, assim como uma leitura atenta da fórmula de Calcedônia, considerando o seu contexto cultural e teológico, mostra-nos que também não é sua intenção uma helenização dos conceitos e do próprio anúncio kerigmático.

Já quanto ao pensamento histórico, este aplicado à cristologia reclama a abordagem da existência terrestre e humana de Jesus, com categorias históricas, dinâmicas e funcionais, em contraste com o aspecto estático e ôntico da Fórmula de Calcedônia. Esta, que afirma solenemente a integridade das naturezas humana e divina de Cristo unidas na sua pessoa divina, é transformada a partir de dentro pela perspectiva histórica ao se explicitar a realização histórica dessa unidade na relação concreta de Jesus com Deus, relação que engloba a história de Jesus, com seu movimento e as tensões da sua dimensão divino-humana, presente nos escritos neotestamentários ${ }^{229}$.

A fé de Calcedônia é transformada contudo, não alterada. Muda a compreensão do conteúdo, mas não o conteúdo em si. O contributo da perspectiva histórica ajuda a explicitar a identidade divino-humana de Jesus, confessada pelo NovoTestamento, pelos Símbolos batismais e pelas Fórmulas dogmáticas, tornando este patrimônio dogmático acessível ao homem contemporâneo.

Àqueles que crêem que seja possível redescobrir o "verdadeiro homem" Jesus de Nazaré com a condição de libertá-lo da estrutura calcedoniana da divindade-humanidade, A. Grillmeier (+1998) afirma que é precisamente dentro desta estrutura que ele recebe o seu verdadeiro significado, sem o qual seria

228 VON BALTHASAR, H. U. Solo l'amore è credibile., pp.11-39.

229 SCHILSON, A.; KASPER, W. Cristologia., pp.16-17. 
impossível fundamentá-lo teologicamente. Procuram retirar Jesus Cristo do conceito de hipóstase e aplicar a noção de criação à origem e à manutenção da humanidade de Cristo $^{230}$. Grillmeier mostra que somente depois de Calcedônia é que este ponto foi mais bem esclarecido, em particular com relação à doutrina da hipóstase de Cristo. Esta doutrina implica na teoria da "en-hipostasia", a qual afirma a "in-existência" da humanidade de Cristo na hipóstase do Logos, elaborada por Leôncio de Jerusalém. Este esquema, que pode ser compreendido erroneamente, possui, porém, a ideia fundamental de encarnação com a "potência criativa" de Deus, noção anterior ao Concílio de Calcedônia, que concebe a encarnação do Filho como um ato "criador", um evento que pode ser explicado somente na potência de Deus creator mundi. Se disto não se fala na fórmula calcedoniana é porque se trata de uma premissa geralmente aceita, apesar dos mal-entendidos de Êutiques ${ }^{231}$.

Assim, a importância soteriológica do Concîlio de Calcedônia é também fundada sobre a vertente da teologia da história. O cruzar das noções de "sem confusão" e de "sem divisão", mas, sobretudo, a tensão presente na expressão "uma hipóstase em duas naturezas" servem para exprimir o fato de que a pessoa de Cristo é o modo perfeito de união entre Deus e homem, Deus e mundo. Assim, a teologia cristãtem a possibilidade de encontrar o exato equilíbrio entre monismo e dualismo, entre pura transcendência divina e a imanência que não admite elevação. Sendo assim, zelar pela integridade da humanidade de Cristo, é expressão máxima de fidelidade ao Concílio de Calcedônia.

\section{2}

\section{Piet Schoonenberg}

Embora faça uma cristologia ascendente, o pensamento de Schoonenberg está ligado ao hino de Filipenses (FI 2,6-11). A cristologia kenótica que se desvela em seu estudo quer evidenciar a total desapropriação de Deus na existência humana de Jesus Cristo. E é precisamente aí que Schoonenberg, com intenções claramente cristológicas, procura valorizar a humanidade de Jesus, sem, contudo, diminuí-la.

A investigação cristológica de Schoonenberg está a serviço da própria prática pastoral. Seu pensamento vai de encontro a um monofisismo implícito no senso comum dos fiéis, visto que para muitos a humanidade de Jesus é até

${ }^{230}$ GRILLMEIER, A. Gesù il Cristo nella fede della Chiesa., p.975.
${ }^{231}$ lbid., pp.975-977. 
mesmo desprezada em prol de sua divindade, pois, afinal de contas, é de Deus mesmo que se espera realização das expectativas mais angustiantes do coração humano. Por isso, Schoonenberg se empenha em uma cristologia ascendente, que parte da manifestação puramente humana de Jesus para devolver à fé cristológica a sua imagem mais pura e tradicional. Seu esforço o conduz a uma reinterpretação da fórmula do concílio de Calcedônia.

Na obra Ein Gott der Menschen, Zürich-Einsiedeln-Köln, 1959, traduzida para a língua francesa em 1973 em Paris sob o título I/ est le Dieu des hommes, Schoonenberg apresenta uma nova concepção no seu modo de compreender a cooperação de Deus e do homem no ser do mundo e da graça. Para ele, Deus e homem não agem no mesmo plano como se um fosse oponente do outro. $\mathrm{Na}$ verdade, a ação criadora de Deus é capaz de abarcar o homem e toda ação humana, ou seja, o homem como ser criado é dom de Deus, de modo que ele mesmo é o sacramento do encontro com Deus. Assim, para fazer um jogo de palavras, a ação de Deus se manifesta no homem e se comunica ao homem pelo homem em uma relação de alteridade que é única; de modo que nunca é somente Deus ou o homem quem está em ação, mas constantemente os dois juntos indissociavelmente. Neste sentido, o homem está radicalmente aberto a Deus, pois Este, até na ação de sua graça, só se manifesta no homem ${ }^{232}$.

\subsection{1}

\section{A Fórmula de Calcedônia e a crítica de Schoonenberg}

Esta compreensão cristológica de Schoonenberg abre espaço para uma análise muito precisa do núcleo da fórmula calcedoniana, que em suma afirma ser Jesus Cristo verdadeiro Deus e verdadeiro homem, uma só pessoa em duas naturezas. Afirmação fundamentada na cristologia bíblica, que traz consigo o dado da preexistência de Jesus como pessoa divina, o que é demasiadamente salientado na fórmula conciliar - bem verdade que em objeção ao adopcionismo, mas em detrimento de sua humanidade. Assim, Schoonenberg faz duras críticas contra o modelo conciliar de Calcedônia que define uma unidade da pessoa de Cristo em detrimento da sua personalidade humana, o que será denominado de an-hipostasia da natureza humana no contexto da união hipostática ${ }^{233}$. O Cardeal Walter Kasper de modo muito simples, sem, contudo, ser simplório, faz uma admirável síntese da crítica de Schoonenberg ${ }^{234}$ como segue abaixo em 5 tópicos:

\footnotetext{
232 SCHOONENBERG, P.Il est le Dieu des hommes., p.48.

233 Ibid., 24s.

${ }^{234}$ SCHILSON, A.; KASPER, W. Cristologia., pp.106-107.
} 
1- O termo "natureza" tem em nossos dias uma compreensão totalmente diferente daquela do contexto de Calcedônia. "Natureza", como conceito moderno, significa uma realidade infrapessoal, sem consciência, liberdade e intersubjetividade, enquanto que o termo "pessoa" traz em seu conceito todos esses atributos. Sendo assim, a expressão "uma só pessoa em duas naturezas" compreendidas nas categorias de hoje, não seria apropriada e até mesmo contrária a cristologia tradicional, pois segundo o modelo tradicional de compreensão, "natureza" é absolutamente definida pela consciência e liberdade; e é a partir daí, deste conceito, que se busca colocar em evidência o que Jesus possui em sua essência que seja comum aos homens e a Deus.

2- A fórmula calcedoniana parece justapor natureza divina e natureza humana, o que é teologicamente insustentável, visto que Deus e homem acabam por ser justapostos como realidades equivalentes, e até mesmo, em certa medida, opostas. Deve-se até admitir que o concilio não nega o abismo que há entre ambos e que afirma a sua coexistência sem concorrência, mas, na realidade, a maneira como isso se procede é ignorada.

3- Apesar da fórmula de Calcedônia ter evidentemente a sua fundamentação bíblica, ela traz consigo uma índole eminentemente ontológica, ao tentar definir a essência de Jesus Cristo. De modo que este modelo não proporciona espaço para enunciados bíblicos e históricosalvíficos.

4- Precisamente por esse caráter metafísico e ontológico da definição calcedoniana sobre a pessoa de Jesus, a sua história de vida, morte e ressurreição passa desapercebida.

5- A fórmula conciliar não resolve o problema da personalidade de Jesus. Há que se questionar se a afirmação da filiação divina de Jesus resolve a compreensão da complexidade de sua pessoa ou diminui a sua realidade humana de modo inaceitavelmente contrário ao testemunho neotestamentário.

Com efeito, Schoonenberg expõe de modo preciso e sucinto as limitações da fórmula dogmática de Calcedônia e ao mesmo tempo prepara terreno para uma outra abordagem sua cujo cerne está na unidade da pessoa de Jesus. Para ele Jesus é antes de tudo um sujeito, e esta verdade é testemunhada pelo Novo Testamento. Ele se relaciona de modo unicamente íntimo com o Pai celeste. É 
Ele o Alter com quem o homem Jesus conversa, e não o Filho divino ${ }^{235}$. E justamente porque o diálogo de Jesus é dirigido inteiramente ao Pai, ele não se desenvolve em si mesmo, ou seja, entre o homem Jesus e o Filho divino. Pois, se isso ocorresse, estaria comprometida a unidade de sua pessoa. $E$ ainda, ao reconhecermos em Jesus uma humanidade completa e se considerarmos a imanência do ato criativo de Deus, tudo há de "se opor à negação de uma pessoa humana própria e de um ato de ser humano verdadeiro em Jesus Cristo de modo que Jesus Cristo é uma pessoa única. Ele é uma pessoa humana"236.

Tal compreensão serve como base da cristologia de Schoonenberg, que segue por um itinerário que passa por uma hermenêutica dos textos que afirmam a preexistência ${ }^{237}$. Daí surge a preocupação de como entender os enunciados tradicionais sobre a preexistência de Jesus contidos no Novo Testamento. Eis aqui o núcleo de toda a cristologia de Schoonenberg, para quem todos os enunciados de preexistência de Jesus devem sempre partir do Jesus terrestre, a quem temos acesso pelo Novo Testamento. Assim, os enunciados contidos na Bíblia, na Tradição e no Magistério sobre a preexistência e divindade do Filho, nunca podem contradizer a plena manifestação humana de Jesus. Todavia, pelo que vimos até aqui, faz-se mister a seguinte crítica: Schoonenberg negligencia a afirmação da Trindade pessoal e pré-temporal de Deus ao focar demasiadamente a ação histórico-salvífica de Deus que faz uma distinção pessoal do Pai, do Filho e do Espírito Santo. Mas nestes termos não se estabelece propriamente uma distinção pessoal da Trindade, mas sim modal, ou seja, modos distintos da manifestação de Deus na história da salvação. Sendo assim, é somente na pessoa humana de Jesus Cristo que um modo de Deus vem a se revelar como pessoa Filho de Deus. O axioma fundamental de Karl Rahner que diz que a Trindade econômica é a Trindade imanente, e vice-versa, é até adotado, porém, de modo superficial. Com efeito, Schoonenberg passa em disparado pela "pré-temporalidade" de Deus, sem, contudo negá-la. É evidente que esta doutrina trinitária não dá conta dos enunciados que versam sobre a preexistência contidos nas Sagradas Escrituras e na Tradição; entretanto, esta premissa, que em suma afirma que o Filho de Deus só vem a ser pessoa em Jesus, se constitui na única abertura, ainda que estreita, de acesso à tese fundamental da cristologia de Schoonenberg, segundo a qual há que se inverter o modelo de Calcedônia, isto é, a pessoa humana de Jesus deve ocupar o núcleo da questão.

\footnotetext{
235 SCHOONENBERG, P.Il est le Dieu des hommes., p.41.

236 Ibid., pp.49-50.

${ }^{237}$ Ibid., p.57s.
} 
No presente, não é a natureza humana, mas a natureza divina que é an-hipostática no Cristo, porém com este detalhe de precisão: isto ocorre na medida em que não conhecemos a personalidade do Verbo fora do homem Jesus. Mas, sobretudo, na nossa concepção, não é a natureza humana que é en-hipostática na pessoa divina, mas a natureza divina que é en-hipostática na pessoa humana ${ }^{238}$.

A teoria "en-hipostática do Verbo" 239 precisa ainda ser suficientemente aprofundada na direção de uma cristologia sem dualidades, segundo Kasper ${ }^{240}$. Pois tal teoria não confere a sua expressão pessoal à natureza divina, mas somente no homem Jesus Cristo. Seria um "substituir das duas naturezas de uma só pessoa pela presença absolutamente soberana de Deus nesta pessoa humana"241. Por isso Schoonenberg desenvolve esta teoria apresentando e interpretando a transcendência humana de Jesus, no qual Deus mesmo se manifesta e se torna presente. Segundo Schoonenberg, tudo depende desta mesma presença que fundamenta a "identificação dinâmica: Jesus é Deus"242. Daí ele insistir tanto na presença do Deus pessoal e Pai de Cristo, e aprofundar esta transcendência de Jesus mostrando o seu amor pelo ser humano e pela sua liberdade.

Esta fórmula vai de encontro ao modelo de Calcedônia, precisamente por Ihe ser inverso. Assim, Schoonenberg torna possível um redescobrir da vida terrestre de Jesus naquilo de mais humano que ela possui. E ele o faz a partir das categorias relativas ao conhecimento e à vontade de Jesus, onde se percebe a vida de Jesus em crescimento da presença divina nele. "A filiação divina de Jesus é, conjuntamente com a sua qualidade de homem, uma realidade em devir: a plenitude da divindade toma posse de Jesus, com totalidade cada vez maior"243.

Assim, as tentações de Jesus, bem como a sua fé e a sua ignorância em relação ao futuro tornam-se admissíveis. Contudo, Schoonenberg dá um destaque sui generis à ressurreição de Jesus. Ele a compreende como a ressurreição de uma pessoa humana, ou seja, corporal, visto que somente assim torna-se aceitável a cristologia por ele apresentada da realidade terrestre de Jesus e da presença de Deus, de que está repleto, de modo que Jesus permanece a mesma pessoa até na sua consumação celeste. Com efeito, compreende-se, então, a identidade do corpo terrestre e do corpo ressuscitado como uma expressão concreta da identidade da pessoa terrestre e da pessoa ressuscitada ${ }^{244}$.

\footnotetext{
238 lbid., p.64.

239 lbid., p.66.

240 SCHILSON, A.; KASPER, W. Cristologia., p.109.

241 SCHOONENBERG, P.I/ est le Dieu des hommes., p.71.

242 lbid., p.72.

243 lbid., pp.155-156.

244 lbid., p.187.
} 
Entretanto, a via de acesso a esta verdade da consumação da pessoa de Jesus é somente a fé, assim como a já presença de Deus na sua transcendência humana só é apreendida a partir da fé. "Não é a nossa fé que faz ressuscitar Jesus, mas é o Ressuscitado que se oferece à nossa fé"245.

Schoonenberg tem o mérito de perceber a ameaça à humanidade de Jesus e de inverter o modelo de Calcedônia, abrindo um horizonte de possibilidades à cristologia. Para ele o Cristo que é Filho eterno e consubstancial de Deus corre o risco de ser esvaziado da sua realidade em benefício da pessoa divina ${ }^{246}$. Ele ainda alenta que o Jesus dos evangelhos tem no seu Pai o seu Tu direto, e as suas palavras e obras estão imediatamente relacionadas com o Pai.

A pessoa divina do Verbo não pode ser, como o Pai, um "Tu" ante o homem Jesus. O Verbo é, portanto, pessoa - e é o Filho - não perante o homem, mas nEle; ele é en-hipostático no homem que é o Cristo, o Filho do Deus vivo. ${ }^{247}$

O esboço cristológico de Schoonenberg valoriza a existência histórica de Jesus. Não como uma existência estática, mas dinâmica, em desenvolvimento, em crescimento; o que está mais de acordo com o testemunho bíblico.

\section{3}

\section{Edward Schillebeeckx}

Edward Schillebeeckx em seu esboço cristológico desenvolveu o que ele próprio chama de cristologia meta-dogmática, cujo ponto de partida é a experiência da comunidade cristã primitiva, experiência com o Ressuscitado. A partir do método histórico-crítico, ele se empenha em uma exegese teológica que Ihe abre caminho para desenvolver uma cristologia narrativa ou cristologia da experiência.

Através do método histórico crítico ele investiga a historicidade do cristianismo primitivo, para a partir daí descobrir a dimensão profundamente teológica da lgreja primitiva. É a chamada hermenêutica teológica da experiência aplicada por Schillebeeckx, não para uma reconstrução meramente histórica, mas para perscrutar teologicamente a experiência também teológica que a comunidade faz de Jesus ${ }^{248}$. Tal cristologia da experiência ${ }^{249}$ consiste precisamente na experiência da salvação de Deus que os discípulos fazem

\footnotetext{
245 Ibid., p.194.

246 Ibid., p.204.

247 Ibid., p.205.

248 SCHILLEBEECKX, E. L'approccio a Gesú di Nazaret., pp.35-36.

249 Schillebeeckx desenvolve esta sua teoria na obra intitulada Esperienza umana e fede in Gesù Cristo.
} 
através da pessoa concreta de Jesus, a partir de suas obras e palavras. Contudo, esta mesma experiência salvífica de Deus é mediada por fatores culturais da comunidade que também a interpreta e a transcreve no Novo Testamento.

O cristianismo, enquanto experiência de Deus, é transmitido como a história de uma experiência ${ }^{250}$. O próprio encontro com Jesus é um encontro históricosalvífico, isto é, uma experiência da salvação de Deus em Jesus na história, que para nós é expressa escrituristicamente nos livros do Novo Testamento, que por sua vez nos manifestam uma pluralidade cristológica. Esta pluralidade é decorrente dos próprios elementos de mediação na transmissão da revelação, a saber: a língua, a linguagem, a cultura, a política, etc. Tudo isso exige uma reflexão teológica acurada e uma opção interpretativa da experiência fundante. $A$ transmissão da revelação, por sua vez, exige uma reflexão da reflexão.

O anúncio da revelação constitui precisamente o que chamamos de Sagrada Tradição, que não é estática, mas dinâmica porque também se converte, ou se expressa em anúncio. Assim, Revelação e experiência não devem ser concebidas como realidades autônomas, mas intimamente relacionadas, ainda que a Revelação transcenda toda experiência. Pois Deus mesmo se revela através da experiência humana. Assim, Jesus faz aquela original experiência de Deus-Abbá, os discípulos, por sua vez, fazem a experiência de Deus-Abbá como salvação em Jesus e, por fim, a comunidade cristã atualiza e toma como sua esta experiência salvífica, que é transmitida como mediação eclesial de salvação ${ }^{251}$.

Sem atribuir propriamente um valor de verdade de fé e sem estabelecer graus de superioridade e inferioridade, Schillebeeckx distingue duas categorias de afirmações nesta relação entre Revelação, Tradição e experiência teológica, enquanto realidade fundante, a saber ${ }^{252}$ : afirmações de primeira categoria, em que Deus oferece sua salvação aos homens em Jesus; e afirmações de segunda categoria, em que se questiona quem e como é esse homem Jesus em quem Deus manifesta sua salvação. O Novo Testamento é o melhor testemunho destas duas categorias de afirmação. Quanto à primeira, é precisamente o Novo Testamento que nos narra como Jesus, a partir de sua experiência de Deus como Abbá253, não somente promete, mas realiza com suas palavras e atitudes a salvação de Deus ${ }^{254}$, em meio a uma história de sofrimento, opressão e injustiças,

\footnotetext{
250 SCHILLEBEECKX, E. Op.cit., p.18.

251 Id. La questione cristologica., p.17.

252 ld. Jesus, a história de um vivente., pp.514-515.

253 Id. Esperienza umana e fede in Gesù Cristo., p.20.

254 Id. La questione cristologica., p.22.
} 
ao anunciar e tornar presente a proximidade iminente do Reino de Deus ${ }^{255}$. Se tal experiência é verdadeiramente fundante, ela também é uma experiência de salvação. Para Schillebeeckx, o testemunho do Novo Testamento nos permite a percepção de que a soteriologia precede a cristologia ${ }^{256}$, bem como lhe dá sentido.

Para os escribas, Jesus foi contra a piedade com base na lei, enquanto ele nunca tem se dissociado de sua experiência do Pai, Abbá, experiência que é libertadora em sua vida. (...) Sua experiência de Deus-Abbà é única na sua mensagem de liberdade e estilo de vida. ${ }^{257}$

A experiência salvífica de Deus, sobre a qual descorremos, leva-nos necessariamente ao questionamento sobre a pessoa de Jesus, em quem Deus se manifesta como salvação para os homens. Deste questionamento provém a questão cristológica ${ }^{258}$, que já presente nos documentos neotestamentários, procura interpretar a pessoa de Jesus de modo concreto, isto é, a partir de suas palavras e atitudes.

Quer dizer: "Cristologia" é algo mais relativo do que uma "teologia de Jesus", embora não sem importância, exatamente para a boa compreensão dessa teologia. Na sua mensagem, Jesus não se preocupava com a sua própria identidade. Sua identidade era identificar-se com a causa de Deus como a causa do ser humano, e com a felicidade do ser humano como a causa de Deus. Mas, a cristologia inverte, centrando a atenção exatamente para a própria identidade de Jesus ${ }^{259}$.

Contudo, aí há que se respeitar e levar em consideração as diferentes tradições cristológicas, que constituem verdadeiros modelos de interpretação. Com efeito, toda reflexão que brota da experiência fundante, que aqui chamamos de afirmações primeira categoria, inscreve-se dentro das afirmações de segunda categoria, onde também se inclui a história dos dogmas cristológicos, cuja finalidade é em última análise garantir as afirmações de primeira categoria.

Há toda uma problemática cristológica cuja evolução podemos verificar ao longo dos concílios constitui parte da reflexão cristológica das afirmações de segunda categoria ${ }^{260}$. Os próprios documentos neotestamentários, em sua pluralidade de tradições cristológicas, refletem sobre a identidade de Jesus na medida em que esta reflexão é capaz de levar a experiência salvífica. Contudo, nos séculos que se seguem ao surgimento das comunidades apostólicas, esta mesma reflexão vai ao encontro de novos contextos culturais com seus respectivos modelos de pensamento e investigação. Assim, gradativamente foi se

\footnotetext{
${ }^{255}$ Id. Jesus, a história de um vivente., pp.105-156 e pp.163-198.

256 Id. La questione cristologica., p.19.

257 Id. Esperienza umana e fede in Gesù Cristo., p.20.

258 Id. Jesus, a história de um vivente., p.551

259 lbid.

260 lbid., 515.
} 
caminhando para a definição da verdadeira e perfeita divindade de Jesus, bem como de sua verdadeira e completa humanidade. Neste sentido, segundo Schillebeeckx, a relação perfeita de Jesus com o Abbá põe a cristologia, como reflexão sobre Jesus, em completa sintonia com a teologia sobre Jesus.

\title{
4.3.1
}

\section{A identificação hipostática}

O esboço cristológico de Edward Schillebeeckx é claramente ascendente, de modo que para ele a relação entre Jesus e Deus deve ser analisada a partir de sua original relação com o Abbá. Assim, o próprio evento da ressurreição deve ter o seu significado teológico redimensionado, em sentido a afirmar, por um lado, a identidade de Jesus como pessoa inseparavelmente unida a Deus, e, por outro, a profundidade da relação entre Jesus e o Abbá; uma relação de tal intimidade, intensidade e solidez, que nem mesmo a morte foi capaz de romper. Na verdade, a morte foi vencida e assim viabilizou a plenificação desta íntima comunhão com o Abbá.

\begin{abstract}
Jesus pertencia àquele a quem ele chamava de "Abbá", e isso foi confirmado por Deus na ressurreição; por isso, a ressurreição é também a confirmação divina da mensagem de Jesus e de sua praxe de vida. Isso significa também que o conteúdo da libertação escatológica, formulada na linguagem da fé com o termo "ressurreição dentre os mortos", vem da atuação histórica de Jesus, isto é, de suas palavras e ações que assim são "confirmadas"261.
\end{abstract}

Para Schillebeeckx, o verdadeiro valor de toda experiência religiosa está no fato de sermos criaturas, seres humanos e, por isso, finitos, ou seja, a própria autonomia humana é limitada e sustentada pela ação criadora de Deus. Assim, cada ser humano sendo "ele mesmo", é mais "de Deus" do que "de si mesmo"; de modo que a sua experiência é um vestígio da realidade de Deus, no próprio cerne da sua existência ${ }^{262}$. Tal realidade criatural, enquanto "ser de Deus", desde a experiência radical e única de Jesus com o Abbá, torna-se uma questão cristológica. Assim discorre o autor sobre o assunto:

A pergunta cristológica, então, reza assim: Será que essa condição fundamental da criatura, esse "ser de Deus" - comum a todos os seres humanos, mas diferenciado segundo o perfil da situação e personalidade de cada um -, será que também em Jesus isso é base suficiente para esclarecer sua tão excepcional vivência pessoal com Deus como "Abbá"? Ou seja, será que essa vivência tão excepcional transcende a condição comum das criaturas? Exatamente como questão cristológica é que isso supõe na fé o reconhecimento da salvação definitiva de Deus em Jesus; de fato, fora disso nenhuma pergunta cristológica teria sentido. A

\footnotetext{
261 lbid., p.648.

262 Ibid., p.658.
} 
confiança da fé na salvação definitiva, vinda de Deus, em e por Jesus, já pode ter respondido implicitamente a uma pergunta cristológica; então, é bom extrair daí essa cristologia implícita ${ }^{263}$.

Schillebeeckx afirma que esta definição da condição humana como criatura, pode ser chamada de "enhypostasia", que significa o fato de a pessoa humana ser assumida na "pessoa" (hypóstasis) de Deus ${ }^{264}$.

De fato, a presença criadora de Deus no ser humano (ou o permanecer do ser humano em Deus, como a teologia oriental prefere dizer) é o próprio Deus, isto é, a sua "pessoa" (hypóstasis); então, o "ser de Deus e estar em Deus" de uma criatura é sem dúvida uma "en-hypóstasis"; não há diferença. Se Deus, na sua essência, é pura "hypóstasis" (como mais outra definição), então "ser criatura" é naturalmente uma "união hipostática"265.

Este dom de si de Deus é tão ímpar e particular em Jesus, que o faz ser reconhecido e confessado como "o Filho".

Por causa da original profundeza da experiência de Jesus, vendo-se como dádiva de Deus Pai, a fé eclesial - também a fé cristã ecumênica - identificando-se com ele, chamou Jesus de "o Filho", especificando assim a relação de Jesus, como criatura, com Deus. O que na linguagem não-religiosa é chamado - com razão - de pessoa humana, é chamado Filho de Deus na linguagem da fé cristã, por causa da relação constitutiva deste homem com o Pai266.

Com efeito, esta origem do ser humano em Deus, que temos até aqui tratado, deve ser revelação da sua mais profunda humanidade. De modo que vista sob uma ótica cristológica, deve ser compreendida como base para a afirmação da humanidade de Jesus. Pois, se na linguagem de fé designamos como pessoa humana essa relação da criatura com Deus ("ser para Deus"), o homem Jesus é essa pessoa devido a esta sua relação ímpar com Deus. Neste sentido, o próprio "ser Filho do Pai" de Jesus, encontra o seu fundamento na sua humanidade, enquanto pessoa. $E$ este relacionamento único de Jesus em seu estado criatural com o Pai, de modo algum pode ser encarado como perda de humanidade, mas sim como relação autêntica que aprofunda e completa sua humanidade ${ }^{267}$.

Assim, Schillebeeckx recusa a negação da pessoa humana, isto é, a anhipostasia, que caracteriza a perda de humanidade, e, por isso, não deve ser aplicada a Jesus. Sua humanidade deriva de sua especial relação com o Pai.

Na sua humanidade, Jesus é tão intimamente "do Pai", que é exatamente nisso que ele é "Filho de Deus". Isso por si sugere que o centro da humanidade de Jesus não estava dentro dele mesmo, mas em Deus Pai. Os dados históricos sobre Jesus também o mostram: o centro, o apoio, a "hypóstasis" (no sentido de algo que dá

\footnotetext{
263 lbid.

264 Ibid.

265 lbid., p.659.

266 Ibid., p.660.

267 lbid., pp.661-662.
} 
estabilidade) era o seu relacionamento com o Pai, com a causa do qual ele se identificava $^{268}$.

Todavia, Schillebeeckx afirma que essa relação especial de Jesus com o Pai é precedida com prioridade absoluta pela relação do Pai com Jesus. A esta relação primeira e prioritária ele afirma ser chamada de "a Palavra" (o Verbo) pela antiga tradição cristã, de modo que ela é identificada com a relação intratrinitária, eterna e preexistente do Pai com o Logos. Aqui se insere algo como "identificação hipostática" entre o Logos e Jesus, sem anhypostasia, ou seja, este Jesus pessoa humana, dentro da sua limitação humana de um modo psicológica e ontologicamente também humano de existir, é realmente o Filho. Assim, Jesus não é uma pessoa humana já constituída que vem assumida pelo Logos na encarnação, mas é precisamente na encarnação que ocorre uma plena identificação entre o Logos e Jesus como pessoa humana ${ }^{269}$.

A relação constitutiva com Deus já está implícita no cerne de toda criatura como ente e como pessoa. Assim, graças à identificação hipostática do que em Deus se chama "Filho de Deus" (a partir de Jesus, com o seu modo de ser pessoalmente humano), o homem Jesus é uma relação constitutiva (de filho) para com o Pai; essa relação, no desenvolvimento dinâmico da vida humana de Jesus, cresce, tornando se uma enhypostasia mútua, aprofundando-se até culminar na ressurreição. Nisso, Jesus está diante do Pai e do Espírito, mas não diante do Filho de Deus! Nele, a consciência divina única e a liberdade absoluta como é vivida de modo intradivino "de forma filial" (na perfeita unidade com o Pai), é humanizada, formando um centro humanamente consciente e uma liberdade humana (situada) ${ }^{270}$.

\section{4 \\ Walter Kasper}

Walter Kasper, não somente é teólogo sensível às mudanças que vem ocorrendo na teologia atual desde a década de 1960, precisamente a partir da tarefa de renovação imposta pelo Concílio Vaticano II, como também interage e contribui magistralmente com este movimento de renovação da teologia e da própria lgreja.

O Concílio Vaticano II não foi propriamente um concílio dogmático no sentido de querer definir de modo preciso questões teológicas ou dogmáticas ainda abertas. Mas, foi um concilio de índole pastoral que teve como objetivo primeiro reapresentar de maneira mais atual e em uma linguagem mais acessível a Verdade pura e íntegra de Deus ${ }^{271}$. Neste sentido, a própria índole do concílio impunha ao debate teológico a tarefa de renovação da lgreja a partir de reflexões

\footnotetext{
268 lbid., p.663.

269 lbid., p.672.

$270 \mathrm{lbid}$.

271 Mensagem à Humanidade proclamada pelos Padres Conciliares a 20/10/1962.
} 
pertinentes à sua essência, à sua unidade e relação com a sociedade atual. Contudo, a questão eclesiológica proposta pelo concílio esbarra na questão cristológica. De modo que podemos afirmar ser precisamente aí onde se encontra o punctum saliens não somente do Concílio, mas do próprio fundamento da lgreja e de sua missão no mundo de hoje. É neste sentido que Walter Kasper afirma:

Ora, o sentido e o fundamento da lgreja não estão em uma determinada ideia, nem em um princípio e um programa, nem tampouco em dogmas específicos e preceitos morais, nem em certas estruturas eclesiais ou sociais. Tudo isto tem o seu direito e o seu significado, no seu devido lugar. Entretanto, o fundamento e o sentido da Igreja estão em um nome, em uma pessoa: Jesus Cristo ${ }^{272}$.

Kasper ressalta que o nome Jesus Cristo não é como um nome composto, mas como uma profissão de fé: Jesus é o Cristo, o Messias ungido pelo Espírito, a consumação escatológica da história, a salvação definitiva do mundo. Esta confissão de fé em Jesus Cristo fundamenta tanto o caráter determinado, insubstituível, e a especificidade do cristianismo, quanto a sua abertura universal e a sua responsabilidade que se estende ao mundo inteiro. Para Kasper, os problemas em nível eclesiológico que se impõem na atualidade, não podem ser resolvidos senão a partir de uma cristologia renovada ${ }^{273}$. Ainda segundo o teólogo alemão o momento de renovação pelo qual a questão cristológica passa desde a segunda metade do século XX tem como ponto de partida a celebração dos 1500 anos do Concílio de Calcedônia em 1951, bem como a importante contribuição de Karl Rahner em sua reflexão cristológica ${ }^{274}$.

A questão cristológica, por sua vez, tem como ponto de partida, segundo Kasper, a própria profissão de fé neotestamentária: Jesus é o Cristo, que, outrossim, representa o resumo da fé cristã, de maneira que a cristologia não é outra coisa senão a explicação mais conscienciosa possível desta profissão de fé $^{275}$. A grande questão consiste em saber como apresentar uma tal cristologia, a fim de atender às exigências de hoje. É nesta perspectiva e ainda diante da atual discussão cristológica que Walter Kasper propõe três tarefas essenciais: a) uma cristologia como história ou narrativa, já que o ponto de partida é a profissão de fé, que por sua vez é fruto de uma história concreta e precisamente determinada, o acontecimento histórico que motivou a mesma profissão de fé deve se manter vivo como memória; b) uma cristologia em horizonte universal, pois como a vida e o mistério de Jesus possuem uma pretensão universal, essa segunda terefa não

\footnotetext{
272 SCHILSON, A.; KASPER, W. Cristologia abordagens contemporâneas., p.121.

273 lbid., p.122.

${ }^{274}$ KASPER, W. Jesús el Cristo., p.40.

275 Ibid., p.38.
} 
pode ser deduzida das necessidades dos homens e da sociedade, mas ela deve ser considerada e assumida diante das reais necessidades dos homens e em correspondência analógica com os problemas atuais, de maneira que a tradição cristológica e a própria memória de Jesus sejam consequentemente compreendidas como tradição viva, e por isso mesmo conservadas com uma fidelidade criadora capaz de gerar verdadeiramente uma fé viva. Tal pretensão universal deve, por outro lado, levar a cristologia a um diálogo aberto com as ciências modernas; c) uma cristologia de vertente soteriológica, que conduza à revalorização do significado salvador da pessoa e da história de Jesus Cristo. A profissão de fé em Jesus o Cristo, vista a partir destas três tarefas, levam o teólogo alemão a considerar como evidente a distancia entre cristologia ontológica e cristologia funcional ${ }^{276}$.

\subsection{1}

\section{A mitificação da verdadeira imagem de Jesus}

Frente à figura de um Jesus mitificado, Walter Kasper reconhece a necessidade de um redescobrimento de Calcedônia. $O$ autor reconhece que a doutrina bíblica e eclesiástica, segundo a qual Jesus é verdadeiro homem dotado de alma e plena liberdade não é suficiente e nem tem desenvolvido a consciência do cristão comum. Ao passo que um redescobrimento da definição dogmática de Calcedônia contribuiria positivamente para desmitologizar a imagem de Jesus de um certo docetismo cristológico na fé prática do homem de senso comum, da mesma forma como também contribuiria substancialmente para ressaltar 0 autêntico sentido da fé em Cristo.

\footnotetext{
É inegável que na compreensão cristã habitual, Jesus Cristo é visto mais ou menos como um Deus que caminha pela terra e em que o ser humano não é, no fundo, mais que um disfarce e ornamento atrás do qual Deus mesmo fala e atua. Cabe discutir se estas concepções são sempre tão grosseiras como amiúde se apresentam: Deus disfarçado de Papai Noel, Deus que se veste de uma espécie de macaco para reparar o mundo avariado, etc. De qualquer maneira, a doutrina bíblica e eclesiástica segundo a qual Jesus é homem verdadeiro e pleno, com alma e liberdade humanas não está muito perfilada na consciência cristã comum. Frente a tais concepções, é legítimo e até necessário desmitologizar, precisamente para ressaltar o autêntico sentido da fé em Cristo ${ }^{277}$.
}

Para Kasper os próprios evangelhos pressupõem de modo muito natural a humanidade de Jesus de Nazaré ao relatar emoções muito humanas, tais como alegria, tristeza, dor, compaixão, sem, contudo, objetivar traçar um perfil

\footnotetext{
276 lbid., pp.45-51.

277 lbid., p.82.
} 
psicológico. Ainda segundo Kasper, para além dos traços da humanidade de Jesus, relatados pelos evangelhos, sobretudo pelos sinóticos, está a sua obediência ao Pai. Tal obediência pressupõe em Jesus uma humanidade total, a partir de sua razão, livre vontade e em última análise, alma humana racional.

O que está por trás da preocupação de Kasper com a verdadeira humanidade de Jesus, já definida e defendida pela tradição, é uma outra preocupação: a questão soteriológica.

$\mathrm{Na}$ questão da plena humanidade enquanto o corpo e a alma, o que preocupa é a liberdade de sua obediência e, consequentemente, a humanidade da salvação. Trata-se de que Deus, incluso em sua própria causa, não age prescindindo e fazendo caso omisso do homem, mas sempre através dele e mediante sua liberdade, de maneira que Jesus não é um mero meio de salvação nas mãos de Deus, mas mediador pessoal da salvação ${ }^{278}$.

\subsection{2}

\section{A Fórmula de Calcedônia e suas limitações históricas}

Kasper em seu esboço cristológico reconhece que a fórmula de Calcedônia possui elementos externos ligados à política e a pressupostos intelectuais da época. ${ }^{279} \mathrm{Contudo}$, para além destes fatores externos sim, porém relevantes, "este dogma, ainda que parta de uma perspectiva histórica limitada, trata de uma questão fundamental de fé" ${ }^{280}$, ou seja, "da questão fundamental da salvação, assim como do problema especulativo fundamental da mediação entre Deus e o homem"281.

O autor compreende o dogma da união da divindade e humanidade em Jesus em íntima correspondência com o Novo Testamento. Todavia, ele adverte que, ainda que "com razão se tenha convertido Jo 1,14 no ponto de partida bíblicoteológico do desenvolvimento posterior histórico-dogmático na cristologia (...) seria um equívoco histórico buscar já em João a doutrina das duas naturezas"282. O teólogo alemão afirma que em plena conformidade com os escritos neotestamentários, quando se explicou a relação ôntica Jesus-Pai, no modo ontológico foi necessário pressupor a autocomunicação do Pai a Jesus, ou seja, a relação eterna intratrinitária a que chamamos Logos. Kasper entende o mistério da encarnação como a experiência de Jesus do amor do Pai e a resposta obediencial a este amor. Pois é assim que o Novo Testamento apresenta o que hoje conhecemos como a doutrina das duas naturezas em uma só pessoa.

\footnotetext{
278 Ibid., p.308.

279 Ibid., pp.333-338; Cf. Id. I/ dogma cristologico di Calcedonia., pp.119-122.

280 KASPER, W. Jesús el Cristo., p.330.

281 lbid.

282 lbid., p.337.
} 
A unidade do homem Jesus com o Lógos se expressa no Novo Testamento somente de modo indireto como razão íntima da unidade entre o Pai e Jesus. Teremos que interpretar a comunhão pessoal entre Jesus e o Pai como comunhão essencial, e a comunhão essencial, como realização pessoal. O característico desta comunhão essencial é ser pessoal e relacional 283 .

Em sua análise da fórmula do Concilio de Calcedônia, Kasper ressalta que o concíilo não foi uma helenização da doutrina da lgreja no que diz respeito à doutrina de união das duas naturezas, mas sim uma deshelenização, visto que aí se subtraem de um mesmo objeto dois aspectos entre sí antagônicos: unidade e dualidade. Neste sentido, o concílio mantém a unidade na dualidade e a dualidade na unidade entre Deus e os homens ${ }^{284}$.

Duas conclusões básicas podemos aqui elencar das reflexões de Walter Kasper fruto da sua análise acerca da fórmula de Calcedônia:

1. A definição dogmática do concílio de Calcedônia, na problemática e na linguagem do seu tempo, é um reflexo muito preciso do que teremos na história e no destino de Jesus, pelo menos segundo o testemunho do Novo Testamento; ou seja, em Jesus Cristo, Deus mesmo se enxertou na história humana, vindo ao encontro do ser humano de um modo completo e totalmente humano. A profissão do dogma cristológico de que Jesus Cristo em uma só pessoa é verdadeiro Deus e verdadeiro homem, deve se impor e se considerar como a explicação válida e perenemente obrigatória da Escritura.

2. A definição dogmática do concílio de Calcedônia também significa uma limitação acerca do testemunho cristológico da Escritura. O dogma foca exclusivamente na constituição interna do sujeito humano-divino. Subtrai esta questão do contexto total da história e do destino de Jesus, além de sua relação com o Pai, o que leva a uma diminuição e até descuramento da própria índole escatológica da cristologia bíblica. Assim, ainda que o dogma de Calcedônia seja uma exegese perenemente obrigatória da Escritura, deve ser necessariamente integrado ao testemunho global da mesma Escritura e há de ser interpretado a partir daí.

Kasper, em seu esboço cristológico a respeito de Calcedônia, dedica-se primeiramente ao desenvolvimento do conceito clássico de persona, e em seguida parte para a compreensão profunda da união hipostática. Para tanto ele mesmo se questiona:

283 lbid., p.338.
284 lbid. 
(...) como se pode chegar hoje a apropriar-se, no sentido existencial, como a verdade de nossa salvação, a verdade da fé de que Deus se fez homem, assumindo no ser de pessoa do Lógos eterno uma natureza humana sem mescla nem separação?285

A resposta o autor concebe a partir de dois movimentos: ascendente, isto é, a partir do homem; e descendente, isto é, a partir de Deus; tendo como pressuposto a história. O ponto de partida para Kasper é o modo como se revelam Deus e o homem na obediência de Jesus para com seu Pai e no seu serviço para conosco 286 .

No movimento ascendente, Kasper descreve a pessoa como relação. A pessoa se realiza somente em relações: consigo mesmo, com os outros, com toda a criação. Trata-se de uma linha horizontal de relações que se cruza com a linha vertical da relação total do homem com Deus, que o leva ao âmbito do ilimitado ${ }^{287}$. Deste modo, segundo o teólogo alemão, "a pessoa se pode definir, em definitivo, a partir de Deus e em ordem a Ele; Deus mesmo pertence à definição da pessoa humana"288.

Ao estender o conceito tradicional de pessoa, com uma interpretação personalista, Kasper concebe a pessoa como mediação entre o infinito e o finito. Tal distância entre ambos não pode ser estabelecida a partir do homem, mas somente a partir de Deus. Adentramos, assim, em um outro nível: o homem é a capacidade obediencial da mediação cuja concretude histórica percebemos em Jesus. Por isso, Jesus Cristo é a salvação do homem em pessoa ${ }^{289}$.

Com efeito, a cristologia há de conceber-se a partir das categorias anteriormente mencionadas: ascendente, enquanto o homem é mediação indefinida entre Deus e ele mesmo ${ }^{290}$; e descendente, enquanto Jesus se compreende a partir de sua experiência ímpar do Pai, manifestada através de sua livre obediência, que, por sua vez, é resposta da inclinação amorosa de Deus ao homem ${ }^{291}$. Segundo Kasper, é justamente essa abertura infinita do homem e da profunda imanência do Lógos em Jesus, que nós conhecemos como união hipostática. Assim, “Jesus não é outro senão o próprio Lógos, mas também é pessoa humana, porém no Lógos e pelo Lógos, ou seja, a pessoa do Lógos é pessoa humana"292.

\footnotetext{
285 Ibid., p.356.

286 lbid., p.357.

287 Ibid., p.358.

288 lbid.

289 lbid., pp.358-360.

290 Ibid., p.361.

291 lbid.

292 Ibid.
} 
A mediação entre Deus e o homem, em Jesus, só se pode entender a partir da teologia trinitária. Como verdadeiro Deus e verdadeiro homem, Jesus é a exegese histórica da Trindade. Nesta perspectiva trinitária, podemos afirmar que Kasper compreende a união hipostática como a plena realização do ser do homem e a manifestação do íntimo mistério intratrinitário de Deus ${ }^{293}$. Para o cardeal alemão, a última palavra em termos de atualização do dogma de Calcedônia é verificável, ou percebida, mesmo que indiretamente, a partir da divindade de Jesus, que por sua vez é percebida a partir da sua relação com o Pai, com o Abbá no Espírito Santo ${ }^{294}$. Assim, toda a doutrina cristológica pode ser considerada à luz daquilo que era o fundamento da vida, da obra e da morte de Jesus, a saber: sua pessoal relação com o Pai, que por sua vez só se pode entender teologicamente como acontecimento no Espírito Santo. Neste sentido, tal pensamento nos aponta para uma cristologia orientada pneumatologicamente ${ }^{295}$.

Com efeito, uma leitura da doutrina de Calcedônia com matizes tão personalistas, constitui o início de um humanismo cristão, de modo que a perfeita comunhão entre divindade e humanidade em Jesus constitui a base da liberdade humana e cristã; e mais: na própria aceitação de tudo o que o homem possui de bom, justo e virtuoso; ao mesmo tempo em que é ainda uma crítica a tudo aquilo que o aliena e o afasta de sua mais genuína vocação. É também uma chamada a uma realização mais perfeita que escapa do meramente intramundano e material.

\section{5}

\section{Bernard Sesboüé}

O sacerdote jesuíta francês Bernard Sesboüé é um dos autores contemporâneos que tem se dedicado ao estudo da evolução da compreensão do dogma, propondo uma leitura assim atualizada da cristologia calcedoniana. Ele o faz a partir de duas obras principais, onde aborda explicitamente o tema da cristologia de Calcedônia com o interesse de explorar as vias possíveis de uma cristologia, não formalmente calcedoniana, mas a partir dela e respeitando a visão desta definição conciliar.

Sesboüé, à luz da proposta hermenêutica de H. G. Gadamer ${ }^{296}$ pensa ser necessário realizar hoje um profundo estudo crítico das fórmulas conciliares, usando de honestidade para com a distância histórica e para com reconhecimento

\footnotetext{
293 lbid., p.364.

294 lbid.

295 Ibid.

296 SESBOÜÉ, B. Le Procès Contemporain de Chalcedoine, Bilan et Perspectives., p.55.
} 
das possíveis perdas, assim como para com a reabilitação das ideias de autoridade e tradição. Contudo, Sesboüé considera que a aplicação destes princípios à hermenêutica conciliar deve levar em conta as regras hermenêuticas, que por sua vez não são aplicáveis na mesma medida aos concílios como se aplicam nos demais casos. De modo diverso, há que se considerar alguns aspectos fundamentais, tais como:

- uma fórmula conciliar já constitui em si mesmaum ato hermenêutico de outro texto diante do qual se situa como secundário ${ }^{297}$;

- o ambiente concreto em que nascem as fórmulas dogmáticas, geralmente em torno de uma situação polêmica, a qual converte a fórmula em uma interpretação reguladora da mensagem de fé que se encontra na Sagrada Escritura ${ }^{298}$;

- a distância histórica que ajuda a situar a definição dogmática, não só no seu contexto original, mas no contexto de gerações posteriores, já que seu sentido atual não é o mesmo daquele de sua origem, em que se encontrava intrinsecamente ligado a uma urgência eclesial299.

Sesbüé adverte que tais aspectos auxiliam a reler Calcedônia, visto que o intérprete de hoje precisa, sobretudo, considerar que "não deve concentrar sua atenção nas antigas heresias que a definição combateu, mas pelo contrário, deve estar atento à atualidade que pode significar frente às tentações contemporâneas que a contradizem e a denunciam" 300 .

Todavia, o teólogo francês sustenta a necessidade de equilibrar o peso das afirmações diante das críticas à Calcedônia. Para isso ele aponta três caminhos:

I) O bom uso da definição conciliar, tendo em vista que a intenção original de Calcedônia era oferecer uma regra de interpretação da mensagem neotestamentária e da tradição frente às heresias do momento e não oferecer uma cristologia completa, menos ainda reescrever o Novo Testamento ${ }^{301}$;

II) Fazer justiça à Calcedônia diante das acusações de ter helenizado o kerigma com a utilização de terminologia grega não levando em consideração o contexto. Contudo, os conceitos utilizados são gregos

\footnotetext{
297 lbid., p.58.

298 Id. É este caráter normativo da definição conciliar, equiparável a um ato de jurisprudência, o que leva a quase que obrigatoriamente a retomar o desenvolvimento posterior, como acontece, por exemplo, nos concílios dos séculos VI e VII frente à Calcedônia e em Calcedônia frente à Nicéia e Éfeso.

299 lbid., p.59.

300 Ibid., p.60.

301 lbid., pp.60-63.
} 
porque os crentes, seus interlocutores, eram linguística e culturalmente gregos. $E$ estes mesmos conceitos-chave não devem ser lidos isoladamente, mas dentro do seu contexto geral da definição, tendo da mesma forma presente o objetivo cristológico principal: a distinção das naturezas, salvaguardando a unidade de um só e mesmo Cristo ${ }^{302}$.

III) Reconhecer os verdadeiros limites de Calcedônia, por exemplo: a) a ignorância da dimensão histórica de Jesus, enquanto não se menciona explicitamente o ministério público, a paixão, a morte e a ressurreição; o que leva a pensar a encarnação como um momento pontual, de modo a pôr em xeque um dos principais objetivos da fórmula dogmática, isto é, a consubstancialidade da humanidade de Cristo com a nossa; b) a maneira como afirma a dupla consubstancialidade de Cristo, ou seja, em duas naturezas, de modo que a dualidade corre o risco de ser entendida como dualismo. De qualquer maneira, deve-se compreender como um paradoxo de linguagem, pois enquanto se deseja expressar a divindade e humanidade unidas em um mesmo Senhor e Cristo, conservam suas diferenças irredutíveis.

\subsection{1 \\ Uma cristologia à luz de Calcedônia}

Para Sesboüé, a abordagem da teologia de Calcedônia não pode ser reduzida a uma mera tradução da fórmula dogmática, o que conduziria a mais uma vez tomar o concílio por aquilo que ele não é ${ }^{303}$. Mas a tarefa que urge é interpretar a mensagem do Novo Testamento transmitido pela lgreja levando em consideração a visão e a regra de leitura que tem marcado o concílio ${ }^{304}$, de modo que a melhor maneira de saber até que ponto estamos ligados a fórmula é verificando a qual ensinamento neotestamentário ela nos reporta ${ }^{305}$. É este o objetivo mais fundamental de Bernard Sesboüé em sua obra intitulada Jesus Cristo na tradição da lgreja, onde ele procura encontrar uma via de interpretação e de atualização das doutrinas conciliares, evitando cair nos excessos, visto que o sentido de estudar a doutrina de Calcedônia em nossos dias consiste em retomar o círculo hermenêutico e aplicar os conceitos dogmáticos a intuição da

\footnotetext{
302 lbid., pp.63-66.

303 lbid., p.68.

304 Ibid.

305 lbid.
} 
leitura bíblica. ${ }^{306}$ Trata-se de um movimento inverso àquele que forjou a fórmula dogmática.

Não se pode afirmar que a proposta de Sesboüé seja propriamente original. Ela está em acordo com o movimento cristológico de nosso tempo e dele se beneficia. Sesboüé, assim como outros autores contemporâneos, compreende que para que um esboço cristológico seja fiel às exigências hodiernas sem contudo, trair as linhas da tradição traçadas por Calcedônia, deve-se reportar aos diversos aspectos que constituem o mistério total de Cristo, a partir de uma leitura fundamentada no testemunho neotestamentário. Pois a teologia especulativa e sistemática deve sempre se remeter aos diversos aspectos com os quais o Novo Testamento narra a identidade humano-divina de Jesus. Com efeito, tal articulação da cristologia deve basear-se na relação ou correspondência que há entre a existência pré-pascal, ou seja, a vida terrena de Jesus na qual revela a profundidade do seu ser a partir da singular relação com o Pai, e a sua manifestação gloriosa como o Ressuscitado, a qual constitui a mais genuína revelação de Jesus.

Destarte, uma proposta que pretenda ser realmente original, deve, em última análise, superar o dualismo que há entre uma cristologia do baixo e uma cristologia do alto, ou seja, uma cristologia funcional e uma cristologia ontológica, bem como levar a um retorno ao Novo Testamento como texto fundamental. É mister e de capital importância que a união das diversas posturas cristológicas possa ser compreendida como uma possibilidade de complementação entre si, e não como contraditórias. Sendo assim, o dualismo deve dar espaço a uma verdadeira dualidade, em que se respeite a contribuição das posturas cristológicas em questão tendo por referência o próprio testemunho do Novo Testamento, que comporta em si diversas linguagens e as duas posturas cristológigas supracitadas, que nos permite respeitar a distinção entre Deus e o homem.

\section{6 Joseph Moingt}

Outro teólogo contemporâneo que propõe uma cristologia que intenta responder às atuais exigências da teologia frente a definição de Calcedônia é o jesuíta francês Joseph Moingt, que em sua obra $O$ homem que vinha de Deus,

${ }^{306}$ SESBOÜÉ, B. Jésus-Christ dans la Tradition de l'Eglise., p.36. 
cunha a expressão rumor ${ }^{307}$ de Jesus, que por sua vez marca a entrada de Jesus na História, isto é, precisamente quando se começou a falar dele.

\begin{abstract}
Jesus não entrou na história quando nasceu, não pertence à história porque viveu, mas desde que se falou dele e porque ele fez falar dele, desde que e porque o zunzum e sobretudo a fé que suscitou criaram história. Relataram o que ele havia dito e feito, anunciaram-no como Cristo antes de se narrar ordenadamente o seu personagem e antes de definir a identidade de sua pessoa. Será desse anúncio surgido no dia seguinte à morte de Jesus, muitas vezes feito em forma de narrativa, ou de uma mistura de pequenos fragmentos de narrativas (...), que nascerão progressivamente, nos decênios que se seguirão, as redações evangélicas; e será dele que nascerá de maneira igualmente direta, antes mesmo que essas redações tenham assumido sua forma atual, a pregação da lgreja antiga, organizada em torno de sua "regra de fé", que foi o motor da dogmática do Verbo encarnado 308.
\end{abstract}

Este rumor seria propriamente um primeiro momento menos formal caracterizado pela pregação da Igreja primitiva, um relato que não se interessa tanto pelos feitos e gestos de Jesus como um taumaturgo ou fazedor de milagres, mas pelas ações de Deus em relação a Jesus ou realizadas por seu intermédio, que deveria conduzir à percepção de uma relação verdadeiramente diferenciada, ímpar frente a Deus. Destarte, este rumor sobre Jesus se desenvolve como boa notícia, cujo ponto central será a ressurreição, que se deparará com situações culturais novas que exigirão a adequada adaptação, de maneira que o anúncio possa entrar e transformar. Este primeiro anúncio evidentemente encontrará dificuldades principalmente nos dois primeiros séculos, e a gnose é o exemplo mais claro disso. Contudo este período dos dois primeiros séculos também nos trazem passos significativos que expressam uma progressiva expansão e aceitação deste primeiro anúncio cristão.

Moingt chama a atenção para um aspecto importante, que é a inversão de perspectiva da cristologia que mudará totalmente a maneira de apresentar o discurso cristão para a posteridade. Há aí uma acentuação da divindade e preexistência do Logos.

Assim, muito cedo e por mais de vinte séculos, esteve delimitado o campo de uma "cristologia descendente", cuja orientação excessivamente metafísica e anistórica é censurada pela teologia moderna, que imputa habitualmente à "helenização" do discurso cristão ${ }^{309}$.

Para Moingt é verdadeiramente de grande importância lançar luz sobre este aspecto, ou seja, sobre esta inversão expressa pela teologia do Lógos, visto que

\footnotetext{
307 (...) o rumor, mistura de fé e de dúvida, de espera e de recusa, que propagavam os primeiros anúncios de Cristo e que já se divulgavam em torno de Jesus. MOINGT, J. O homem que vinha de Deus., p.19.

308 Ibid., p.23.

309 lbid., p.83
} 
ela traz consigo o germe da futura teologia da encarnação ${ }^{310}$, onde se encontra o centro do posterior desenvolvimento da cristologia, e de onde também provém a necessidade de revisão do pensamento cristológico em nossos dias. Com efeito, tais afirmações nos levam a entender que a percepção da referida inversão, igualmente, leva nosso autor a percepção da necessidade de reconstrução da cristologia na atualidade. Contudo, não é nosso interesse nos debruçar sobre todos os aspectos da obra de Moingt, mas somente sobre a sua proposta cristológica naquilo que tange nosso tema.

Assim, Moingt compreende que o germe de uma nova cristologia se encontra na introdução da concepção de encarnação, que passará por uma radical mudança ao longo dos séculos até os nossos dias. Segundo o jesuíta francês, a divindade de Cristo estava atestada desde o início do rumor sobre Jesus. Contudo, esta divindade era mais de ordem funcional que metafísica.

A afirmação se ressente fatalmente do limite do conceito de preexistência; Cristo é considerado um funcionário divino, que tem privilégio e o encargo de "representar" Deus, como mostram as argumentações sobre os nomes "mensageiro" e "enviado", ou sobre a "teofanias' do Antigo Testamento, que desempenharam um grande papel na atribuição que the é feita do nome "deus", como quando a Bíblia chama sucessivamente "deus", "homem", "anjo" o personagem que aparece a Abraão (Gn $18,1.3 .16 ; 19,1)$. Quanto ao discurso feito aos gregos, a grande fluidez do conceito filosófico de "logos", não permite - ainda não - dar força absoluta à sua atribuição a cristo. Cristo é classificado na esfera do divino, sem ser totalmente assimilado ao próprio Deus. Sua divindade é mais de ordem funcional que metafísica ${ }^{311 .}$

Contudo, a própria motivação de fé em Cristo como "deus" recebe seu impulso de fé em Cristo salvador ressuscitado, o que não necessariamente exclui que a inteligibilidade dessa fé se exprima com o auxílio das categorias recebidas do ambiente cultural pagão; pelo contrário, antes tais categorias se prestavam ao anúncio que se queria fazer de Cristo como enviado divino.

Utilizavam, sobretudo, a extensibilidade do conceito de "divindade" à qual se prestava a filosofia pagã, enquanto a Bíblia não Ihes permitia tratar o nome de Deus como um nome comum. Essa observação assumirá toda a sua importância quando virmos o conceito de "Filho de Deus" passar do registro da funcionalidade, da messianidade, em que o deixa o Novo Testamento em seu conjunto, ao registro ontológico da comunicação da natureza divina ${ }^{312}$.

É justamente aqui onde se dá essa inversão. Em um primeiro momento, o rumor da primeira comunidade sobre Jesus, enquanto Filho de Deus, está estreitamente unido ao evento escatológico da ressurreição, em um segundo momento o anúncio dará destaque a sua vinda na história, o que faz remontar ao

\footnotetext{
310 lbid.

311 lbid., p.80

312 lbid., pp.81-82.
} 
começo dos tempos, ao início da criação, visto que a encarnação será considerada como o início de uma nova criação. Ainda que esta seja a única grande inovação do discurso dos primeiros anunciadores, ela está carregada de implicações.

Para Moingt o Concílio de Nicéia provocará profundas implicações para a cristologia, e consequentemente para a teologia. A partir do símbolo de Nicéia, o sujeito humano apresentado pelos evangelhos como Filho de Deus, Jesus Cristo, vai ceder espaço ao sujeito divino, preexistente, Filho de Deus encarnado. As implicações cristológicas e teológicas deste movimento são sentidas rapidamente tanto no campo teológico, onde se deve abrir espaço no âmbito divino não só a um Filho de Deus, mas, à própria afirmação de que Este é coeterno com o Pai; quanto no campo cristológico, cuja afirmação de que Jesus é verdadeiramente o "Filho de Deus feito homem" cairá como um verdadeiro "efeito dominó" que há de atingir os séculos posteriores. Assim, a definição do Concílio de Nicéia terá profunda e extensa repercussão pelo menos até o Concilio de Constantinopla III, como bem o constata a história da evolução do dogma cristológico.

Após, então, fazer considerações mais situacionais que minuciosas a respeito do Concílio de Calcedônia, Moingt, na obra O homem que vinha de Deus, chega, enfim, à desconstrução no capítulo 3, ponto de partida de sua proposta cristológica. Aí ele enfatiza suas afirmações sobre o Concílio de Nicéia.

O anúncio, objeto da narrativa evangélica, a saber que "Jesus é o Cristo, o Filho de Deus", separou-se da narrativa desde que o discurso da fé se constituiu em Nicéia, como uma nova escritura da história evangélica. A descida do Filho de Deus à terra ficou superimpressa na narrativa como o primeiro acontecimento entre os primeiros, intemporal, anistórico, da vida de Jesus, de maneira que todos os acontecimentos dessa vida, daí em diante, tomam desse primeiro acontecimento, em si mesmo inenarrável, sua verdade analogamente intemporal e anistórica. A narrativa evangélica continua a ser recebida como fonte da fé; não é mais lida como regra de féz ${ }^{313}$.

A primazia do dogma sobre a Escritura dominará a investigação teológica por muitos séculos, até que se retome como ponto de partida o relato evangélico. É o que apontará no século XIX o aparecimento do nome "cristologia", que logo substituirá o tratado De Verbo incarnato. Moingt afirma ser esse o sinal da "desconstrução" por ele defendida, que, não sendo uma destruição, trata-se, com efeito, de uma reconstrução, em que tal cristologia nova não permitirá mais a impostação descendente, ou seja, "de cima", do pressuposto da geração eterna

\footnotetext{
313 Ibid., p.191.
} 
do Verbo, mas abrirá caminho para a impostação ascendente, "de baixo", da história de Jesus de Nazaré ${ }^{314}$.

Depois dos debates da primeira metade do século $X X$, a teologia perdeu a ilusão, se algum dia a teve, de assentar a fé em Cristo sobre pesquisas históricas; mas reconhece a necessidade de levar em conta a historicidade do acontecimento da salvação que ocorreu na existência histórica de Jesus. A nova cristologia procura se reconstruir, desse modo, no eixo do acontecimento pascal, que é o eixo, ao mesmo tempo, da narrativa evangélica e da pregação apostólica ${ }^{315}$.

Neste sentido, a nova cristologia, segundo a compreensão do nosso autor, exige do teólogo a necessidade de remeter-se obrigatoriamente aos relatos neotestamentários e não partir dos enunciados dogmáticos, fazendo uso das ciências modernas e dos métodos hermenêuticos, como ferramentas fundamentais para a interpretação da Escritura, objetivando aquele retorno às fontes, entrando em comunhão com a fé das comunidades apostólicas, deixando guiar-se pela Tradição.

Diante das diversificadas posturas cristológicas, a partir do aniversário de 1500 anos do Concílio de Calcedônia em 1951, Moingt propõe, em relação à cristologia transcendental de Karl Rahner, ser verdadeiramente necessário "voltar resolutamente à história de Jesus e a repensar, de modo radical, a doutrina da encarnação" ${ }^{16}$, assim como também, considerar "o vínculo estabelecido, de um lado, entre Trindade imanente e Trindade econômica; de outro, entre criação e encarnação, sublinhando que esses dois vínculos reclamam, ambos, um prolongamento"317. Já em relação à Schillebeeckx, afirma limitar-se "a partir do acontecimento Jesus como de uma historicidade fundadora, constituída por um ato de fé fundamental que leva em si o vestígio histórico de Jesus"318. Enquanto critica Kasper por seu ponto de partida da preexistência de Jesus, em benefício da ideia de encarnação, sem ter feito o esforço de articular no mesmo relato evangélico uma cristologia ascendente e uma cristologia descendente ${ }^{319}$; Moingt critica também Pannenberg, mas pela doutrina das duas naturezas, enquanto não permite salvaguardar a unidade de Cristo e nem respeitar a verdade de sua existência histórica e humana ${ }^{320}$.

A ideia de descontrução defendida por Moingt traz consigo a proposta de substituir o conceito de encarnação pelo de ressurreição de Jesus, como

\footnotetext{
314 lbid., p.193.

315 lbid.

${ }^{316}$ Ibid., p.218.

317 Ibid.

318 Ibid., p.221.

319 lbid., pp.221-225.

320 lbid., pp.225-230.
} 
fundamento da cristologia e partir de seu comportamento humano diante de Deus, ou seja, sua relação com Deus, para aí estabelecer sua filiação divina. Mas ainda não é o bastante. É preciso igualmente "revisar radicalmente a teologia calcedoniana, a fim de fazer de Jesus Cristo uma pessoa verdadeiramente única, um sujeito verdadeiramente humano, em todo caso no sentido atribuído hoje a esses termos"321.

Esta proposta é de fazer uma cristologia que tenha como fonte principal não as afirmações dogmáticas, mas os anúncios evangélicos, com o objetivo de falar de Jesus como Boa Nova que provoca todo ser humano, como história que se constrói entre Deus e os homens, devolvendo a Ele a nossa história sem, contudo, furtar-Ihe a divindade.

É como consequência a obrigação de fundar a cristologia sobre as narrativas evangélicas e de fazer delas uma leitura de fé, concordante com a fé da Igreja que anuncia Cristo, relatando a história de Jesus, ao mesmo tempo em que respeita a verdade da história compreendida segundo o que pede o espírito moderno. Assim devem ser ultrapassados, mas honrados os debates recentes sobre o Jesus da história. O fundamento desta cristologia será, pois, o acontecimento pascal, que é inseparavelmente a morte e a ressurreição de Jesus, e sobre essa base é que deverá ser estabelecida a filiação divina "desse homem" morto e ressuscitado, com a condição de estabelecer em seguida, deixando-se sempre levar pelas narrativas e anúncios evangélicos, a eternidade do dom que Deus faz de seu Filho aos homens, e de verificar assim o conceito de encarnação ${ }^{322}$.

\section{7 \\ Hans Küng}

É vasta a produção literária de Hans Küng, contudo, aqui nos interessa apenas o seu esboço cristológico, mas precisamente naquilo que tange a fórmula dogmática do Concílio de Calcedônia, alvo de críticas deste controverso teólogo suíço.

Küng questiona a cristologia calcedoniana destacando alguns aspectos essenciais que, em sua opinião, deveriam ser revistos à luz das exigências de nosso tempo. Tal questionamento é expresso em duas de suas obras: $A$ Encarnação de Deus e Ser Cristão.

Segundo o teólogo suíço, o problema fundamental da cristologia clássica está no fato de que ela implica uma forma ontológica de entender a encarnação e a filiação de Cristo a partir da metafísica grega. Küng pensa que para conhecer o que a fórmula calcedoniana implica na cristologia, é preciso observar toda a problemática cristológica que está por trás, o que nos permite perceber duas

\footnotetext{
321 lbid., p.241.

322 lbid., pp.241-242.
} 
posições bem concretas: uma de direita, fascinada pela divindade de Cristo em declínio da sua humanidade, e outra de esquerda, que se distancia da divindade e se interessa demasiadamente por sua humanidade ${ }^{323}$. Todo o debate cristológico dos séculos posteriores a Nicéia, que havia confessado a igualdade ao Pai no que tange a divindade do homem Jesus como Filho de Deus, vai oscilar entre estes dois polos.

Para Hans Küng, encontrar um ponto de equilíbrio entre estes dois polos é verdadeiramente problemático. E tal problemática é fruto da ideia grega de Deus que serviu como pano de fundo sobre o qual se construiu as definições cristológicas da teologia clássica.

No fundo vemos aqui a divindade transcendente e intangível, que não pode assumir nem matéria e nem elemento corporal, e que igualmente deve se manter longe de tudo que neste mundo signifique dor, encarnação e, naturalmente, antes de tudo, paixão e morte 324

Segundo Küng, "toda a chamada 'doutrina das duas naturezas' não é outra coisa que uma interpretação de cunho helênico, em linguagem e conceito, do autêntico significado de Jesus Cristo"325.

Esta situação em que se encontra a teologia clássica tem provocado diversas tentativas de solução que apontam para além da fórmula dogmática e do próprio Concílio de Calcedônia, chamando a atenção para o Novo Testamento que, sem dúvida alguma, tem se apresentado infinitamente mais rico ${ }^{326}$.

Hans Küng afirma que é possível resumir as objeções que atualmente a teologia faz à fórmula de Calcedônia em três pontos principais que agora reproduzimos:

a) A doutrina das duas naturezas com a sua terminologia e as suas concepções cunhadas na linguagem e na espiritualidade helenista, é incompreensível ao homem hodierno. Por isso é também o quanto possível evitada na própria pregação prática.

b) A doutrina das duas naturezas - como constata a história pós-calcedônia - não ajudou a resolver as dificuldades, antes levou semprea novas aporias lógicas.

c) A doutrina das duas naturezas, na opinião de muitos exegetas, não se identifica com a mensagem original do Novo Testamento: alguns a consideram uma transposição ou em parte uma alteração da mensagem original de Cristo, outros a consideram, pelo menos, como uma interpretação, porém não a única e nem a melhor possíveis ${ }^{327}$.

\footnotetext{
${ }^{323}$ KÜNG, H. El caminho hacia la cristología clássica., p.667.

${ }^{324} \mathrm{Ibid}$.

325 Id. Essere Cristiani., p.167.

${ }^{326} \mathrm{Ibid}$., p.168.

327 lbid.
} 
Diante de tais objeções, o teólogo suíço defende uma cristologia mais voltada para o Jesus neotestamentário. E o faz a partir do seguinte questionamento:

Não se ajustaria mais aos testemunhos neotestamentários e não seria mais adequado ao pensamento marcadamente histórico do homem contemporâneo partir, como os primeiros discípulos, do verdadeiro homem Jesus, da sua mensagem, da sua aparição histórica, da sua vida e do seu destino, da sua realidade temporal e da sua incidência histórica, para indagar a relação deste Jesus homem com Deus, sua unidade com o Pai? ${ }^{328}$

A partir de tal questionamento, Küng propõe, em última análise, uma conversão da cristologia mais especulativa ou dogmática, "de cima", ou seja, à moda clássica, para uma cristologia mais histórica, "de baixo", ou seja, do Jesus historicamente concreto, mais ajustada à mentalidade do homem hodierno, sem, contudo, negar a legitimidade a cristologia tradicional ${ }^{329}$.

A proposta de Hans Küng se aproxima bastante da proposta de outros autores, como Schillebeeckx, Moingt e Panenberg, na medida em que exige uma maior aproximação do testemunho neotestamentário, sobretudo do acontecimento pascal. Mas ele também chama a atenção para o movimento kenótico de Deus ${ }^{330}$, compreendendo a encarnação sob a ótica do "tornar-se". Assim, há que se abandonar por um momento, pelo menos sob o ponto de vista da teologia católica, a ideia helenista ${ }^{331}$ de impassibilidade, pois a concepção de impassibilidade e imutabilidade de Deus proveniente da filosofia helenista é bastante distante daquela da Sagrada Escritura, e é justamente aí onde nascem todas as heresias cristológicas dos primeiros séculos ${ }^{332}$. Com efeito, assumir verdadeiramente o conceito teológico de encarnação, conforme a revelação do Deus cristão do Novo Testamento, implica na possibilidade da passibilidade de Deus em Cristo ${ }^{333}$.

Conforme a compreensão de Küng, uma cristologia que admita a passibilidade de Cristo em sua totalidade contribuirá enormemente para uma possível solução para a questão cristológica, já que os debates posteriores ao Concílio de Calcedônia continuam a oscilar de um polo a outro (divindade e humanidade), o que tem demonstrado que não é correto limitar o padecimento da

\footnotetext{
328 lbid., p.170.

329 lbid.

330 KÜNG, H. Nuevos intentos de resolver la antigua problemática (excurso 5).

331 ld. Imortalidad de Dios? (excurso 4)., pp.700-706.

332 Id. Pode Deus sofrer? (excurso 2)., p.681.

333 lbid., pp.682-686.
} 
humanidade de Cristo e mantê-lo longe de Deus mesmo, sem que sofra detrimento a unidade pessoal de Jesus Cristo ${ }^{334}$.

Destarte, a doutrina da communicatio idiomatum tem muito a contribuir para uma leitura contemporânea da cristologia, visto que ao se expor a unidade de pessoa em Jesus Cristo, fica claro que

não é lícito repartir as propriedades e atividades das duas naturezas entre dois sujeitos, mas que as propriedades e atividades da natureza humana devem provir do Logos divino, e as propriedades e atividades da natureza divina devem, igualmente, ser atribuídas a este mesmo eu, haja vista que ele é o fundamento pessoal da existência da natureza humana ${ }^{335}$.

Assim compreendida, a doutrina da communicatio idiomatum não quer estabelecer unicamente regras de expressão verbal, mas quer antes de tudo dizer algo verdadeiro sobre a realidade mesma de Cristo $^{336}$.

Portanto, segundo Küng, a chave de leitura da doutrina das duas naturezas está em uma cristologia mais próxima do Novo Testamento, conforme os moldes exigidos pela contemporaneidade. Nesta cristologia, digamos renovada, não há mais espaço para uma concepção de Cristo unicamente como Deus incapaz das debilidades humanas, nem tampouco como homem conforme o modelo ebionista.

\section{8 Jon Sobrino}

A partir daqui trataremos do esboço cristológico do teólogo espanhol Jon Sobrino radicado em El Salvador desde 1957, e por isso mesmo seu pensamento teológico é todo construído a partir da realidade da América Latina, o que fez do referido teólogo um importante expoente da Teologia da Libertação. Jon Sobrino foi notificado pela Congregação para a Doutrina da Fé em 2006 devido a inexatidões e incongruências com a doutrina da fé da lgreja encontradas nas obras Jesus Cristo libertador. Leitura histórico-teológica de Jesus de Nazaré e $A$ fé em Jesus Cristo. Ensaio a partir das vítimas. Entretanto, na abordagem que a seguir iniciaremos, malgrado as constantes referências que faremos às ditas obras, não trataremos propriamente destes elementos considerados pela supracitada autoridade eclesiástica como inexatos ou equivocados, haja vista a pluralidade essencial exigida pelo estudo acadêmico e a neutralidade desejada por nós neste exato estágio de desenvolvimento deste ensaio.

\footnotetext{
${ }^{334}$ Ibid., p.688.

335 Id. La dialéctica de las propriedades divinas (excurso 3)., p.694.

336 lbid., pp.695-696.
} 
Pois bem, Jon Sobrino sugeriu a superação dos limites das fórmulas dogmáticas e cristológicas propondo que se recupere a história de Jesus como algo essencial e fundamental na sua afirmação dogmática de que Cristo é o Filho eterno, tendo em conta que as dificuldades podem ser superadas dentro das próprias fórmulas. Ele parte da distinção dentre afirmações sobre Deus: as afirmações históricas, a partir de um fato histórico constatável, e afirmações doxológicas, ou seja, as afirmações sobre Deus-em-si-mesmo, quando Deus é abordado com um adjetivo ${ }^{337}$.

Tal distinção, segundo Sobrino, não nega o que ensina a fórmula de Calcedônia: que Cristo, o Filho de Deus, é verdadeiramente Deus e verdadeiro homem. Na segunda parte da fórmula tem-se a explicação de como coexistem ambas as dimensões, ou seja, a natureza divina e a natureza humana na única pessoa divina de Cristo. Esta união é pessoal, isto é, existe uma só pessoa em Cristo, um último princípio de subsistência, sem que ambas as naturezas se separem e se misturem.

Porém, para Sobrino, as formulações dogmáticas quando analisadas a partir da situação atual deixam a desejar quanto à falta de concreção, de historicidade e de relacionalidade.

\subsection{1 \\ Falta de concreção}

A fórmula dogmática de Calcedônia usa uma linguagem abstrata e termos universais, como divindade e humanidade. Porém, para Sobrino, a dificuldade fundamental para o homem de hoje não consiste em compreender estes termos, mas consiste sim no fato da fórmula calcedoniana dá a impressão de que já se sabe de antemão quem é Deus e o que é ser homem antes do aparecimento de Jesus. O problema aí consistiria em afirmar que em Cristo se uniram de modo pessoal estas duas dimensões já conhecidas. Porém, sabemos quem é Deus e o que é ser homem a partir de Cristo e não vice-versa: Deus não é qualquer divindade, mas o Pai de Jesus; e ser homem não é apenas possuir uma alma racional, mas ser como Jesus. Neste sentido, a Fórmula não estaria a serviço da revelação original ${ }^{338}$.

Sem isto a cristologia esvazia a revelação de seu caráter questionador e evangélico, priva a razão da graça de "deixar-se dar a verdade" e inclusive pode cooperar com a hybris que costuma acompanhar tal saber. Como a aplicação de títulos a Jesus,

337 SOBRINO, J. Cristologia a partir da América Latina., pp.332 -351.

${ }^{338}$ Id. A fé em Jesus Cristo., pp.446-447. 
há também uma aplicação de conceitos a Cristo que pode ocultar mais que revelar339.

Para Sobrino, os conceitos universais utilizados na fórmula calcedoniana dificultam a compreensão do conteúdo da fórmula como expressão de revelação, precisamente porque esses conceitos são muito abstratos. De modo que fica ao critério da razão enchê-los de conteúdos concretos, o que se pode fazer de três formas: cristãmente, inadequadamente e pecaminosamente. A razão pode concretizar os conteúdos cristãmente ao se deixar conduzir pela história de Jesus. Porém, pode fazê-lo inadequadamente, mesmo que haja boa vontade, ao ler seletivamente esta história e dela eliminar tudo o que não se coaduna com o conceito universal prévio que tem de natureza humana e divina. Mas ainda pode também fazê-lo pecaminosamente, ao decidir por conta própria o que é humano e o que é divino, mesmo contra a realidade de Jesus. Esta é apenas uma possiblidade, mas que, segundo Sobrino, não se pode excluir, haja vista que a razão humana é também concupiscente e tende a oprimir a verdade.

\begin{abstract}
Falamos em termos genéricos e falamos de possibilidade, mas a história mostra que essa possibilidade se faz realidade mais ou menos conforme os casos. Noutras palavras, a universalidade da fórmula não supôs um freio (nem teórica nem pastoralmente) a muitas aberrações na apresentação de Jesus Cristo. A conclusão é que se pode ler a fórmula de Calcedônia como afirmação verdadeira, mas não como veículo de revelação, como questionamento de nossa imagem de Deus e do irmão, e como boa notícia de que assim é Deus e assim é o humano ${ }^{340}$.
\end{abstract}

\title{
4.8.2
}

\section{Falta de historicidade}

Como já apontamos, Jon Sobrino também afirma que as fórmulas dogmáticas deixam a desejar quanto à falta de historicidade, característica típica da mentalidade grega; não aparecem as categorias históricas tão típicas do Novo Testamento. Na verdade o que o Logos assumiu é verdadeiramente uma história humana através da qual o homem Jesus vai se tornando homem, e a revelação do Filho vai se fazendo através da revelação da história da humanidade de Jesus. E isso é muito evidente no Novo Testamento; apesar disso, há uma resistência em aceitar a humanidade de Jesus Cristo, visto que não convém ao divino unir-se ao humano porque este é imperfeito, está em constante mudança e sujeito à crises, tentações, sofrimento, morte, etc. Realidades inegáveis em Jesus, mas que são vistas como negatividade e limitação, pois o humano é compreendido em termos conceituais de natureza, e daí a natural inclinação ao docetismo. "A

\footnotetext{
339 lbid.

340 lbid.
} 
conceptualização da realidade como natureza esfuma a realidade concreta de Jesus Cristo, pode anulá-la e até desvirtuá-la, e põe a teologia em um rumo perigoso" 341 .

Ápice desta problemática é a cruz, momento decisivo para a soteriologia pelo seu próprio significado. A cruz vista como natureza é apenas derramamento de sangue, "sacrifício", que por sua natureza operaria a mediação entre o ser humano e Deus. Mas a cruz como história é outra coisa. Seu significado vai muito mais além do derramamento de sangue. Ela é fruto de causas históricas, manifesta uma maneira de ser e de viver, e um modo de relacionar-se com os outros seres humanos, a saber: o amor. A própria soteriologia passa a ser compreendida de um modo diferente a partir da cruz como história.

A cruz como história é a história da cruz, e esta é bem conhecida: Jesus defende os fracos contra seus opressores, entra em conflito com eles, mantém-se fiel nisso e é eliminado porque estorva. A cruz acontece, assim, por defender os fracos, e é por isso expressão de amor. Pode-se então dizer que na cruz há salvação, que a cruz é eu-aggelion, boa notícia. O amor salva e, em última instância, o amor - com suas diversas expressões - é a única coisa que salva ${ }^{342}$.

Para Sobrino, a cruz sem a história concreta de Jesus é apenas derramamento de sangue e morte. De modo que a própria soteriologia fica comprometida, se reduz à magia, arbitrariedade ou crueldade de um deus. Já a cruz com a história de Jesus é capaz de concretizar e transmitir o amor. Trata-se de uma soteriologia encarnada, histórica e eficaz, em que o crucificado viveu humanamente com amor, de modo que a cruz é expressão radical da entrega de Jesus ao longo da vida; vida que é oferecida como salvação. Reproduzir esta vida na história é viver como já salvos.

O mesmo se considere em relação à ressurreição. Pois a ressurreição como natureza, significa apenas voltar à existência, e para aqueles que vivem, significa apenas expectativa de vida além da morte. Já a ressurreição como história é outra coisa. É a esperança de que o mal e a opressão não triunfarão sobre as vítimas.

Cruz e ressurreição como natureza tendem no fim das contas a mostrar um Deus cruel, por uma parte, e um deus ex machina, por outra. Como história, cruz e ressurreição revelam um Deus que é amor. Natureza sem história será sempre um perigo para cair na crueldade sacrificialista da cruz e na magia da ressurreição ${ }^{343}$.

\footnotetext{
341 lbid., p.450.

342 lbid., p.452.

343 Ibid., p.453.
} 


\title{
4.8.3 \\ Falta de Relacionalidade
}

Sobrino também aponta que o conceito de natureza enfraquece e desvaloriza a relacionalidade, o que limita gravemente a Fórmula de Calcedônia. Ao se analisar a realidade do próprio Cristo a ênfase recai na revelação da humanidade e da divindade no próprio Cristo e não na revelação da relação de Cristo com o Pai.

\begin{abstract}
Uma última limitação do conceito de natureza é que enfraquece e desvaloriza grandemente a relação, o que é limitação grave para a cristologia, pois durante sua vida Jesus é apresentado em relação essencial ao pai e ao Reino de Deus. A relacionalidade Ihe é, pois, constitutiva, embora o seu significado específico varie segundo tenha como referência o Pai ou o Reino (entrega ou serviço) ${ }^{344}$.
\end{abstract}

Talvez o problema esteja no fato de que a categoria "relação" pareça muito fraca como veículo conceitual para se afirmar a divindade de Jesus e se preferiu, por isso, as categorias de natureza e pessoa. Com efeito, se perde o dado fundamental dos sinóticos de que a verdade da realidade de Jesus não pode consistir em primeiro lugar em relacioná-lo com o Logos, mas com o Pai. A dificuldade aumenta mais ao se perceber que a fórmula calcedoniana não se relaciona com o Reino de Deus. Sendo assim, corre-se o risco de se fechar o dogma e a cristologia em si mesmos. Isto significa que enquanto a Fórmula se centra na relação homem-divindade dentro do mesmo Cristo, faz esquecer aquela relação mais fundamental da vida de Jesus, a saber: a relação com o Pai.

\begin{abstract}
A filiação significa, então, relação com o Pai enquanto proveniência. Sua base bíblica são as afirmações doxológicas de João, e sua finalidade é expressar o "consubstancial" ao Pai. Ora, para expressar a realidade de proveniência pode-se fazer uso do conceito de "natureza", mas esta, em si mesma, não permite expressar o que há de relação histórica e pessoal entre Jesus e o Pai. Para isso é necessário fazer uso do conceito de pessoa, tal como este se foi desenvolvendo nas discussões trinitárias, e em duas direções: uma centrada na auto possessão espiritual do sujeito, e outra centrada na entrega do sujeito. Esta última é a que ajuda a compreender a relação de Jesus com o Paij ${ }^{345}$.
\end{abstract}

Quando o tema em questão é a divindade de Jesus, Sobrino sugere como modelo explicativo da união pessoal de Jesus com Deus a noção de relação, pois é a partir desta categoria que se pode expressar mais claramente a unidade de Jesus com Deus. A relação de Jesus com o Pai é o indício histórico que temos para afirmar doxologicamente a divindade de Jesus. Ao se falar da unidade pessoal da humanidade e da divindade se quer dizer que Jesus é pessoa, e que

\footnotetext{
344 lbid., p.456.

345 lbid., pp.456-457.
} 
se constitui como pessoa precisamente na entrega ao Pai. O divino de Jesus é a modalidade desta relação pessoal para com o Pai que se dá na história e através da conflitividade da história. Na sua obediência até a morte, Jesus vai recuperando a sua personalidade concreta na entrega ao Pai; assim, é mantendo esta relação até o fim que aparecerá a peculiar relação de Jesus com o Pai.

\begin{abstract}
Ser pessoa é entrar em relação com o outro, o que se consuma na entrega, de modo que Jesus se constitui em pessoa precisamente na entrega a esse outro que é Deus. Nessa entrega Jesus vai resgatando e fazendo concreta a sua personalidade genérica. Mantendo-a até o fim, com total radicalidade, vai aparecendo sua especial e essencial relação com Deus. O que possibilita e exige essa entrega radical - e o que mostra - é a história de Jesus até seu final na cruz, e nada disso pode ficar incluído no termo natureza ${ }^{346}$.
\end{abstract}

A falta de relacionalidade também diz respeito ao Reino de Deus, núcleo de toda a pregação e ação de Jesus, mas que, apesar disso, não se faz presente na fórmula de Calcedônia, isto é, Jesus não aparece em relação com o Reino, o que gera o reducionismo da salvação contido na fórmula ("por nós e por nossa salvação"). Para Sobrino, é preciso recuperar a divindade de um Deus de filhos e filhas pobres.

Recupera-se também, mesmo por implicação, a dimensão negativa da realidade, o anti-reino. Por último, recupera-se o que é essencial para as vítimas: que elas são o destinatário privilegiado do Reino e, assim, as criaturas privilegiadas de Deus. O problema é, então, como recuperar a partir da fórmula, de alguma maneira e sem cair em artificiosidade, a relação de Cristo com o Reino de Deus ${ }^{347}$.

Jon Sobrino adverte que para recuperar a relação de Jesus com o Reino de Deus é imprescindível o retorno aos Sinóticos. E mais uma vez ele propõe a substituição do conceito de natureza presente na fórmula pelo de pessoa, entendida na linha zubiriana. Segundo esta mesma linha, a pessoa de Cristo não pode ser pensada como um sujeito anterior a seus atos. O ser pessoa e o saberse como pessoa é algo que acontece justamente nas ações humanas na medida em que estas atualizam a própria realidade ${ }^{348}$.

É possível, porém, perceber a relação de Cristo com o Reino de Deus na fórmula de Calcedônia, quando se compreende natureza como pessoa. Trata-se também de uma carência de vocábulo apropriado para a questão. Pois, se para

\footnotetext{
346 lbid., p.457.

347 lbid., p.459.

348 lbid. "Esta personificação, o ser pessoa, digo, consiste justamente em per si. Se me permitem o brutal vocábulo suidade (para me fazer entender rapidamente), direi que o problema com que se deve defrontar é justamente com o da transição dinâmica e envolvente da mesmidade para a suidade. É o dinamismo da suidade" (ZUBIRI, X. La estrutura dinâmica de la realidade., p.209). A. González o explica assim: "a pessoa não é alguém anterior à atividade, mas quea realidade pessoal é uma realidade dinâmica em e por si mesma: é o dinamismo da suidade" (Id. La novedad teológica de la filisofia de Zubiri., p.252).
} 
expressar a relação com um Deus Pai existe a linguagem (metafórica) de Filho, para expressar a relação com um Deus do Reino, não há termo na tradição teológica do Concilio de Calcedônia. Para Sobrino, mesmo que a linguagem não seja muito apropriada, não se poderia pensar a relação entre ungidor (Deus) e ungido (Cristo) sem considerarmos uma mesma vontade de construção do Reino de Deus. Pois, caso contrário, Cristo não participaria essencialmente da práxis libertadora transcendente de Deus. Com efeito, sua práxis e amor sobre a terra são a versão histórica da atividade e do amor transcendentes de Deus.

Portanto, a fórmula de Calcedônia sofre de falta de concreção, de história e de relacionalidade. E isto é preciso superar. Contudo, Sobrino adverte que apesar de tais carências, não se pode esquecer aquilo que há de positivo, isto é, que Calcedônia oferece um conteúdo daquilo que se deve historizar, ou seja, o divino e o humano. Longe disto ser uma pequena contribuição, trata-se de um auxílio importante para impostar corretamente o conjunto do humano e do divino, na conceptualidade da época e como se relacionam seus diversos elementos.

\subsection{4}

\section{As afirmações doxológicas da fórmula de Calcedônia}

Sobrino acredita que as afirmações doxológicas só podem ter sentido se encontrarem sua base em afirmações históricas. Isto supõe que se deve analisar a realidade histórica de Jesus. A importância metodológica da Fórmula de Calcedônia consiste em que as cristologias posteriores, qualquer que seja a sua formulação, devem integrar o núcleo fundamental, a afirmação de Cristo como único Mediador entre Deus e a humanidade.

Para que as afirmações conciliares possam ter sentido com prioridade lógica e cronológica a Calcedônia, é mister percorrer um caminho conceitual: quem foi Jesus de Nazaré, como o teorizou o Novo Testamento (as teologias de Paulo, João, Hebreus, Sinóticos...) e a tradição posterior da lgreja (as teologias dos apologetas e dos Padres). Caso não se percorresse esse caminho conceitual, as fórmulas seriam simplesmente ininteligíveis ${ }^{349}$.

Todavia, a divina filiação de Jesus não consiste apenas na sua relação histórica com o Pai como Jesus de Nazaré, mas esta é a base histórica para se confessar aquela. O doxológico é a afirmação da identidade da filiação histórica de Jesus e a filiação divina e eterna de Cristo. Deste modo, ao invés de se começar com a afirmação doxológica descendente da encarnação do Filho eterno

349 lbid., p.476. 
em Jesus de Nazaré, termina-se com a afirmação doxológica de que este Jesus é o Filho eterno. Trata-se da passagem de Jesus histórico para o doxológico, a fim de recuperar a história de Jesus como algo essencial e fundamental na afirmação doxológica de que Cristo é o Filho eterno.

A afirmação de que o Verbo Eterno de Deus se fez homem dá início tanto à cristologia clássica quanto à dogmática, por isso merecem ser chamadas de cristologias catabáticas, ou seja, partem do mistério da encarnação, da afirmação de que o Filho se tornou homem. Recuperando a história de Jesus, o movimento se processa em sentido contrário, ou seja, existe uma evolução ascendente: Jesus vai gradativamente se tornando Filho de Deus. Sobrino alerta que não se trata de adocionismo. Para a cristologia clássica, o Filho Eterno assume a natureza humana; existe, portanto, um movimento histórico e, neste sentido temporal no qual o Filho se faz homem. Contudo, uma vez dado este movimento histórico fundamental, não se percebe claramente o que de histórico exista nesta natureza assumida pelo Filho Eterno. Para o teólogo catalão, quando falamos na história de Jesus, dizemos que o homem Jesus de Nazaré, através de sua própria história, ou seja, vida e obras, vai gradativamente se revelando Filho de Deus. O Novo Testamento afirma a preexistência de Cristo porque seus autores refletiram e narraram a vida de Jesus na qual ele ia crescendo em filiação precisamente a partir de um crescimento na entrega histórica ao Pai. Isto não se refere à divindade de Cristo expressa em termos de natureza, mas ao modo como Jesus de Nazaré foi revelando historicamente sua filiação. Na aparição histórica dessa filiação não há dúvida de que existe um processo, e é a totalidade deste processo, a base histórica para se afirmar sua filiação divina e posteriormente a sua preexistência.

Assim como não podemos compreender a divindade de Jesus sem mencionar a sua relação com o Pai e seu Reino, não podemos também compreender a mesma relação sem analisar sua própria historicidade. A relação de Jesus de Nazaré com o Pai possui uma historicidade. É por isso que Jon Sobrino afirma que Jesus não é somente o Filho, mas também o caminho ao Pai. Neste sentido, é através de sua filiação que Jesus é tido como o sacramento do Pai, o esplendor de Sua glória, Sua visão concreta, na carne e o modo como a Ele chegar. Mas, se Jesus é a Palavra Encarnada do Pai dirigida aos homens, é também a resposta ao Pai, resposta em história concreta, de modo que devemos sim percorrer a história e a historicidade de sua vida. Pois o que se revela no Filho e na Sua história não é apenas uma possível filiação de todos os homens, mas o processo desta filiação, o caminho concreto através do qual os homens tornamse filhos de Deus. 
Quando se deseja abordar de maneira séria e aprofundada a verdade de uma fórmula dogmática, tal abordagem pode ocorrer sob diversos prismas, desde aspectos históricos que possibilitam apreender concretamente a história de Jesus narrada nos Evangelhos até a história das ideias que culminará na fórmula cristológica em que se faz uma afirmação universalmente válida em seu núcleo e que mais tarde há de ser interpretada em diferentes situações e culturas. Além disso, é ainda mister conhecer a verdade da fórmula dogmática ao longo da história. E, por fim, o aspecto mais importante é considerar a existência ou não de seguidores de Jesus que através deste seguimento confessam Jesus como Cristo, ou seja, se há relevância do Jesus histórico para abrir caminhos concretos aos demais homens como modo de aproximação ao Pai.

Neste sentido, para Sobrino a validade da Fórmula de Calcedônia, permanece verdadeira porque mesmo com abordagens cristológicas diferentes, que lhe são posteriores, os cristãos continuam a encontrar a verdade definitiva e, diga-se de passagem, provocativa sobre Cristo pleno Deus e pleno homem, tal como confessa a fórmula calcedoniana.

Numa obra mais recente, Jon Sobrino propõe a categoria de "seguimento a Jesus", típica da teologia latino-americana, como princípio para a leitura da fórmula calcedoniana, apresentando-a como uma fórmula holística, haja vista que o Logos ao assumir a natureza humana pela encarnação se torna mediador de toda a humanidade, nele se dá a unificação dos seres humanos e a vicariedade corporativa (cf. Rm 5,15-19). Ao se conhecer e professar a encarnação como uma realidade última e que exige uma epistemologia específica (de modo doxológico), a partir da alteridade e da afinidade com Jesus, o fiel se torna seu seguidor, ou imitador, sob a ação do Espírito. Desta forma, a profissão de fé implica num caminho teórico e num caminho histórico, que é o seguimento a Jesus, e este é o princípio epistemológico para as fórmulas de fé ${ }^{350}$.

${ }^{350}$ SOBRINO, J. A fé em Jesus Cristo., pp.462-487. 


\section{5 \\ Cristologia Calcedoniana Protestante}

\section{1 Wolfhart Pannenberg}

Partindo de uma cristologia ascendente, ou seja, da humanidade concreta de Jesus, de sua historicidade e da autoridade que reivindica, Pannenberg se debruça sobre uma chamada "Cristologia da Ressurreição de Jesus" 351 . Contudo, este ponto de partida ascendente isoladamente considerado mostra-se insuficiente, visto que o verdadeiro centro e ponto de partida de toda a cristologia é o evento da ressurreição de Jesus. Somente a partir da compreensão do alcance e significado deste evento ímpar podem-se encontrar respostas contundentes para os problemas cristológicos mais fundamentais. Mas é também somente a partir da ressurreição de Jesus, em todo o seu potencial libertador e revelador, que podemos encontrar a unidade histórica de Jesus Cristo e o seu significado universal para os homens de todos os tempos. Para a compreensão desta tese de Pannenberg é preciso que também compreendamos a sua concepção de história e revelação como realidades intimamente ligadas, em que a revelação é consequência e fruto do termo da história universal.

Pannenberg compreende a história como o horizonte onde se desenvolvem a vida humana concreta e o questionamento do homem sobre a realidade, a vida e sobre si mesmo. Nada e nem instante algum escapa deste horizonte universal e englobante. Contudo, o próprio homem se vê impossibilitado de conhecer o verdadeiro sentido da história universal, este permanece-Ihe escondido. Não the é possível apreender de modo único e pleno um evento presente, cujo verdadeiro significado tem continuidade no futuro e só se revelará plenamente no futuro, de modo que este mesmo significado só será plenamente compreendido quando a totalidade da história se tornar visível, ou seja, no seu final. Neste sentido, o que tem valor, o que é plenamente verdadeiro, sem equívoco é o todo, onde se revela o verdadeiro sentido do agir humano, das fases da história, pois tudo permanece

\footnotetext{
351 A apresentação que segue da cristologia de Pannenberg é principalmente fruto de reflexões baseadas em sua obra: PANNENBERG, W. Fundamentos de Cristología., com algumas referências a uma outra obra mais recente: Id. Teología Sistemática. As citações do autor em questão são extraídas da versão francesa da obra ld. Esquisse d'une christologie.
} 
sustentado pela esperança da consumação do sentido. O homem empenha todas as suas energias em descobrir o sentido da realidade, da história e da própria vida. Trata-se de uma busca que lhe atinge diretamente e afeta as ciências naturais, pois só ele é capaz de dar sentido e consistência a toda história e à história de sua própria vida. Mas a verdade sobre si mesmo ainda lhe escapa, a sua verdade e a sua essência ainda não podem ser plenamente conhecidas e nem exatamente determinadas imediatamente, mas somente na consumação total. Assim, o próprio passado torna-se relativo ao presente e ambos relativos ao futuro, que há de revelar o verdadeiro significado do próprio tempo. A unidade e universalidade da história só serão plenamente compreensíveis no seu termo.

\subsection{1}

\section{A história universal e a revelação veterotestamentártia}

Pannenberg tem uma compreensão da revelação veterotestamentária associada à sua compreensão de história universal. Para ele Deus se revela no Antigo testamento nas suas ações históricas em favor de seu povo, ou seja, de maneira indireta, pois a história seria mediação para esta revelação. Contudo, esta revelação histórica de Deus em Israel é marcada por certo caráter provisório. Novas intervenções de Deus na história vão sendo associadas a fatos já ocorridos e revelam outras características deste Deus que se dá a conhecer na história paulatinamente. Neste sentido, ainda ansiamos pela revelação universal de Deus que há de se dar em um ato salvífico que engloba todos os povos e todos os tempos, isto é, a história universal. Até o presente momento Deus só se revelou em atos históricos particulares em que manifestou sua potência. De modo que nós só podemos falar em revelação universal da divindade de Deus na consumação da história da humanidade, isso sem esquecermos que esta mesma consumação é conduzida pelo próprio Deus. Aí, ele se revelará como o Senhor de toda a história. Tal revelação corresponde à esperança apocalíptica do último Israel, que espera a "ressurreição dos mortos" como último acontecimento histórico.

Só é possível compreender o significado da ressurreição de Jesus a partir desta dupla perspectiva de história universal e de auto-revelação de Deus, na sua comum orientação para um evento escatológico consumador da história. Assim, o horizonte de história universal torna possível ao homem a esperança apocalíptica associada ao anúncio da ressurreição.

Se nós não pudéssemos mais partilhar de maneira alguma da expectativa apocalíptica, igualmente impossível seria para nós a fé dos primeiros cristãos em Cristo: com efeito, o que ainda pudesse sobrar do cristianismo depois destas 
exclusões já não teria mais continuidade com Jesus e com a primeira pregação cristã até Paulo352.

Em suma, na ressurreição de Jesus ocorre uma antecipação do fim da história, de modo que em Jesus ressuscitado é realizada a expectativa apocalíptica da "ressurreição dos mortos". Ora, sendo assim, são antecipadas a consumação escatológica da história e a auto-revelação de Deus, ligada a esta consumação. Neste sentido, a ressurreição de Jesus possui um caráter antecipatório, pois ela antecipa o fim da história inteira. Portanto, de uma maneira universal, a ressurreição de Jesus faz surgir o próprio Deus no destino de Jesus.

Embora somente a totalidade da história possa manifestar a divindade do Deus único, e ainda que este resultado só possa ser deduzido no fim da história inteira, não obstante isto, um evento peculiar tem um significado absoluto como revelação de Deus: é o evento Jesus cristo, na medida em que ele antecipa o fim da história. Pela mesma razão, como evento que antecipa o fim, o evento Jesus Cristo não pode ser ultrapassado por nenhum outro evento ulterior, e também precede sempre qualquer compreensão, enquanto os homens ainda estiverem a caminho do futuro aberto do fim dos tempos (Eschaton) ${ }^{353}$.

$\mathrm{Na}$ cristologia de Pannenberg a ressurreição de Jesus é um ponto de partida significativo que serve de base para a solução de muitos problemas do pensamento cristológico. Contudo, Pannenberg, como já aludimos acima, formula o seu pensamento cristológico de modo ascendente, ou seja, do homem concreto Jesus de Nazaré, de seu comportamento, de sua reivindicação de autoridade e de seu destino, visto que esta seria a melhor maneira de compreender a figura humana e a história terrestre de Jesus, cumprindo a tarefa mais autêntica de toda reflexão cristológica: "expor as razões que fundamentam a confissão acerca da divindade de Jesus" 354 .

$\mathrm{Na}$ atualidade a maioria dos teólogos, assim como Pannenberg, considera a cristologia ascendente um dos elementos fundamentais da renovação cristológica. Ora, se a cristologia se interessa pela divindade de Jesus Cristo, o problema central está em como descobrir a divindade deste homem Jesus de Nazaré, de quem nos falam os santos evangelhos. Ao optar por não partir de uma divindade suposta, afirmada desde o princípio partindo de um esquema de preexistência e confirmada à luz de uma leitura apologética dos milagres e prodígios de Jesus, a cristologia deve focar na seguinte questão: como o acontecimento histórico de Jesus leva ao reconhecimento de sua divindade ${ }^{355}$,

\footnotetext{
352 PANNENBERG, W. Esquisse d'une christologie., p.94.

353 PANNENBERG, W. Dogmastische Thesen zur Lehrevon der Offenbarung; Id. (org.). Offenbarung als Geschichte., p.105; SCHILSON, A.; KASPER, W. Cristologia., p.84.

${ }^{354}$ PANNENBERG, W. Fundamentos de Cristología., p.45.

355 lbid.
} 
considerando as características próprias de seu ministério terreno, assim como "o significado decisivo que determina a particularidade específica do autêntico e histórico homem chamado Jesus de Nazaré" ${ }^{356}$ ?

Assim, Pannenberg seguindo o método dos pensadores hodiernos opta por uma cristologia ascendente e expõe seu pensamento cristológico a partir da abordagem da reivindicação de autoridade antecipada do Jesus pré-pascal. Ele se interessa precisamente por aquilo que é particular no comportamento e na pregação de Jesus. Para ele da resposta do ser humano ao comportamento e pregação de Jesus depende o destino dos homens. Trata-se de uma reivindicação universal de Jesus, que atribui a si uma autoridade ímpar cujo fundamento, porém, só Deus, e não o próprio Jesus, pode revelar. Com efeito, Jesus vive na espera da confirmação da sua autoridade no futuro, de modo que Ele antecipa o poder de Deus na sua própria existência. Este movimento de reivindicação de autoridade antecipada por parte de Jesus, antecipa o julgamento e agir o de Deus no seu próprio julgamento e agir. Todavia, ainda é necessária uma verificação.

Ora, isto quer dizer que a reivindicação de autoridade por parte de Jesus, tomada isoladamente, como se tratasse somente da decisão a tomar em relação a Ele, não pode constituir a base de uma Cristologia. Tal Cristologia - e uma pregação fundada nela - permaneceria, no fundo, uma afirmação vã. Tudo se reduz, na realidade, ao problema da relação entre a pretensão de Jesus e a sua confirmação por Deus ${ }^{357}$.

Confirmação que só se dará no evento da ressurreição. Somente na Ressurreição a reivindicação universal de Jesus é confirmada por Deus. Pois na ressurreição de Jesus se cumpre a expectativa apocalíptica de uma ação histórica e escatológica de Deus.

\begin{abstract}
A ressurreição de Jesus desempenha um papel essencial não somente para o nosso conhecimento da sua divindade, mas também para o ser de Jesus. Sem a sua ressurreição dentre os mortos, Jesus não seria Deus, embora a partir da sua ressurreição Ele seja retroativamente um com Deus em toda a sua vida prépascal ${ }^{358}$.
\end{abstract}

Tal valor retroativo da ressurreição confirma a pretensão da atuação prépascal de Jesus, atuação que em um primeiro momento e considerada em si mesma não é garantida por Deus, mas que à luz da ressurreição se manifesta na sua mais elevada legitimação divina.

Contudo, é mister salientar que o caráter confirmatório que Pannenberg considera como sendo próprio da ressurreição deve ser protegido de concepções

\footnotetext{
356 lbid.

${ }^{357}$ PANNENBERG, W. Esquisse d'une christologie., p.72.

358 lbid., pp.282-283.
} 
equivocadas que possam considerar a ideia de exaltação de Jesus como uma participação na divindade de Deus acontecida somente após e por meio do evento da ressurreição, o que resultaria em adopcionismo cristológico. É preciso compreender toda a atividade pré-pascal de Jesus em sua estreita e particular relação com o Pai sob a luz retrospectiva e reveladora da ressurreição, para a partir daí descobrir através de seu verdadeiro significado teológico que a afirmação segundo a qual Deus se manifestou em Jesus só pode ser verdadeira sob o signo da ressurreição de Jesus dentre os mortos ${ }^{359}$.

Com efeito, para Pannenberg a ressurreição é a chave de compreensão de toda a cristologia. A ressurreição de Jesus é - para se fazer um jogo de palavras - definitivamente o lugar definitivo da auto revelação definitiva, e por isso mesmo escatológica de Deus. Tendo como referência a ressurreição de Jesus e partindo daí regressivamente podemos afirmar e compreender a sua unidade com Deus. Pois na ressurreição o próprio Deus de um modo único, identifica-se com Jesus, pelo fato de a auto revelação de Deus no fim da história operar-se por antecipação no destino de Jesus de Nazaré, que deve ser considerado já na sua existência humana verdadeiro Deus, ou seja, em perfeita unidade de essência com Deus. É sobretudo aqui que aparece a força das reflexões e abordagens de Panennberg. É precisamente aqui que ele ressalta a insuficiência da cristologia de separação pré-calcedoniana, ou antioquena, e de união, ou alexandrina, bem como a fragilidade da doutrina calcedoniana das duas naturezas, e todas as tentativas posteriores de compreender a unidade da pessoa de Jesus Cristo como o resultado de uma composição entre o humano e o divino. O núcleo do interesse de Pannenberg está na existência concreta de Jesus, na qual a função e a pessoa se unem de uma maneira ímpar. Para ele Jesus vive como homem plenamente consagrado a Deus em uma consagração exclusiva à função que Ele mesmo recebeu de Deus ${ }^{360}$. A reivindicação pré-pascal de autoridade por parte de Jesus, o seu potente chamado ao Reino de Deus e a vinculação incondicional deste Reino à sua pessoa, revelam pelo menos que Ele teve consciência de sua unidade funcional com a vontade de Deus, e evidentemente com o próprio Deus ${ }^{361}$. Segundo Pannenberg, Jesus vive por inteiro consagrado à missão que the foi confiada por Deus. Ele se mantém fiel à esta missão até às últimas consequências . Tal confiança no Pai até à morte de cruz deve ser entendida como comunhão pessoal do homem Jesus com o Deus por Ele anunciado. Porém, a verdade

\footnotetext{
359 ld. Fundamentos de Cristología., pp.170-175.

360 ld. Esquisse d'une christologie., p.244.

361 lbid., p.428.
} 
profunda da sua auto-entrega, enquanto comunhão vividas entre pessoas, só irá emergir no fim da história de Jesus, na sua ressurreição.

Pela ressurreição que the foi outorgada, Jesus é Revelador da divindade de Deus, pois a Ressurreição consagra a doação total a Deus, que continua a ser dEle: enquanto perfeitamente obediente ao Pai, Ele é o Revelador da divindade de Deus e consequentemente pertence indissoluvelmente ao ser de Deus. É assim que Ele é o Filho ${ }^{362}$.

Assim, Pannenberg se interessa pelo processo da unidade humano-divina levado a termo na vida terrena de Jesus outorgando por sua vez um importante valor confirmatório à ressurreição, com a força retrospectiva que lhe é peculiar e que permite o conhecimento real da pessoa de Jesus, conforme o esquema paulino dos dois estados (cf. Rm 1,3-4) ) $^{363}$. Tal caráter confirmatório e revelador próprio da ressurreição implica na concepção da própria encarnação, que deve ser compreendida no conjunto de toda a vida de Jesus agora a partir da ressurreição.

\section{1 .2}

\section{A crítica de Pannenberg}

Na sua crítica à doutrina de Calcedônia Pannenberg parte da formulação do esquema das duas naturezas. Para ele o referido esquema se detém mais na diversidade das duas naturezas do que na unidade da pessoa de Jesus de Nazaré, o que implica numa apresentação de Jesus como alguém que reúne em si mesmo duas substâncias contrapostas, o que irá constituir a problemática das duas naturezas ${ }^{364}$. Contudo, para Pannenberg a grande questão que se impõe não é somente aquela considerada a afirmação fundamental da teologia cristã que versa sobre a verdadeira divindade e verdadeira humanidade de Jesus, mas a afirmação que a complementa, ou seja, que estas duas naturezas se acomodam em um único e mesmo indivíduo, conforme a fórmula das duas naturezas propostas por Calcedônia, e que este mesmo e único indivíduo é Jesus, o Filho de Deus e, portanto o próprio Deus. Mas esta imagem de Jesus como o Filho de Deus só aparece definitivamente na ressurreição. Neste sentido, para Pannenberg a divindade de Jesus não é apenas uma segunda natureza no homem Jesus, ao lado da sua humanidade, mas alenta que Jesus é precisamente, enquanto é este homem, o Filho de Deus e, portanto, o próprio Deus.

\footnotetext{
362 Ibid., p.431

${ }^{363}$ ld. Fundamentos de Cristología., pp.380-381.

364 lbid., pp.352-354.
} 
Todavia, a união das duas naturezas não é suficiente para se chegar à conclusão acima citada, pois não se pode também desprezar a completa consagração de Jesus ao Deus de sua missão, pois é aí que ele vive o seu ser de Filho inteiramente voltado para o Pai, ou seja, é por sua plena doação de simesmo ao Pai que Jesus é o Filho ${ }^{365}$ e nós o sabemos por sua experiência humana. Aí o conceito de pessoa é re-significado, ora se pessoa é essencialmente um ser relacional, então pessoa deve agora designar uma relação, precisamente a relação estreita do homem Jesus de Nazaré com o Pai, que por sua vez identifica a relação intradivina do Pai com o Filho.

\begin{abstract}
A pessoa de Jesus é, neste sentido, o lugar no qual estão unidos o ser de Deus, do qual ela participa como pessoa da Trindade, e o ser do homem, que é integrado por esta pessoa - antes de tudo, sob o aspecto da carreira histórica de Jesus, mas estendendo-se depois, a partir daí, a cada realidade humana -, como o revela a ressurreição de Jesus ${ }^{366}$.
\end{abstract}

Assim, Pannenberg não se envolve diretamente no esquema das duas naturezas, mas ele se debruça sobre a trajetória da vida de Jesus terrestre na sua doação única a Deus Pai e a aceitação desta doação na ressurreição o que constitui o princípio de conhecimento de sua perene filiação divina. Por isso, não é sem motivos que Pannenberg diz: "Jesus, em sua entrega humana ao Pai, é idêntico com a pessoa eterna do Filho de Deus"367.

Sem querer aqui esgotar a cristologia de Pannenberg quisemos até aqui apontar os traços fundamentais de seu estudo, de modo que podemos afirmar que o ponto de partida dele encontra-se claramente no Jesus terrestre e na singularidade de sua vida terrestre, onde sua reivindicação de autoridade é confirmada no glorioso evento da ressurreição, que aí se coloca co mo antecipação do fim de toda a história, que por sua vez constitui a auto-revelação escatológica de Deus. Esta reivindicação universal de autoridade de Jesus Cristo e seu significado historicamente ímpar para todo o mundo e para todos os tempos parecem-nos perfeitamente adequada e comunicável na atualidade. Assim, a cristologia e principalmente a antecipação da verdade e do sentido supremo de toda a história na ressurreição de Jesus, oferecem a única resposta válida para a questão fundamental do homem, isto é, o sentido todo da realidade. Contudo, o esboço cristológico que leva em consideração a história universal, acaba por negligenciar o destino individual de cada ser humano, bem como a questão do

\footnotetext{
365 PANNENBERG, W. Esquisse d'une christologie., p.431.

366 lbid., p.442.

${ }^{367}$ Id. Fundamentos de Cristología., p.422.
} 
mal e do sofrimento na história, lembremos que a cruz de Cristo não é aqui tratada $^{368}$.

\section{2}

\section{Jürgen Moltmann}

Jürgen Moltmann não aborda propriamente a cristologia do Concílio de Calcedônia, contudo, o seu esboço cristológico reflete, até certa medida, a cristologia calcedoniana, em muito se aproximando do pensamento dos autores anteriores ao salientar as cristologias da ressurreição de Jesus e da cruz, as duas principais premissas do seu pensamento. No entanto, o esboço cristológico de Moltmann traz consigo um diferencial ao destacar a proximidade da cristologia com a escatologia, uma vez que esta última é fundada na própria ressurreição de Jesus, e pelo fato de precisamente aí, na ressurreição, Deus agir escatologicamente, ou seja, Deus age definitivamente e no fim dos tempos em Cristo e por Cristo a fim de cumprir sua promessa, de modo que toda história é agora posta em um horizonte de esperança que ultrapassa os limites do criado e tende para o advento escatológico de Deus.

Cruz e ressurreição. Eis aqui duas premissas que, a pesar de suas diferenças, constituem uma unidade, uma única cristologia, conservando, evidentemente as suas propriedades. Todavia, o elo de unidade destas realidades que, como acima dito, constituem uma só cristologia, é a história concreta e a ação sobre ela, orientada pela capacidade do cristão em dar respostas. Assim, se de um lado a história é o futuro do evento Jesus Cristo, considerado a partir de uma escatologia da ressurreição de Jesus, e a reação correspondente do homem é considerada como esperança e missão; por outro lado, a cristologia deve ser considerada o ser de Deus na história que aparece mais fortemente na cruz de Cristo, símbolo de libertação concreta em relação à idolatria de uma religião política, ao mesmo tempo em que revela um Deus presente na paixão do amor no interior da história.

\section{2 .1}

\section{Cristologia da ressurreição de Jesus}

No pensamento de Moltmann, a Cristologia é expressa como teologia da esperança em perspectiva escatológica, e é sobretudo na sua obra Teologia da

\footnotetext{
${ }^{368}$ SCHILSON, A.; KASPER, W. Cristologia abordagens contemporâneas., p.91.
} 
Esperança que ele apresenta o seu esboço no que tange o referido tema. Em Teologia da Esperança, o supracitado teólogo protestante atribui um significado decisivo à concepção de história e da revelação. Em suma, podemos afirmar que para ele a revelação só se realiza no fim da história, ou no escaton, pois somente aí Deus cumprirá sua promessa e manifestará sua verdade. Mas também podemos questionar: por quê? É aí que se insere essa sua concepção de revelação e história, muito alinhada, diga-se de passagem, com a concepção de Pannenberg.

Para Moltmann, os conceitos de revelação e história só podem ser devidamente compreendidos a partir do evento da ressurreição. No próprio Antigo Testamento, a história e a revelação se inserem no contexto da promessa, em seguida, o no Novo Testamento a própria pregação de Jesus é expressa em matiz eminentemente escatológica, ou seja, referida ao Deus do futuro e da esperança. O próprio anúncio do Reino de Deus, concebido sob a tensão da expressão "já e ainda não", é compreendido como algo já presente sim, mas principalmente compreendido como realidade vindoura, e o seu aspecto presencial só é entendido sob a modalidade da promessa e da esperança, uma vez que esta promessa já contém a presença de Deus no sentido de anúncio de sua vinda futura e ao mesmo tempo a manifestação escatológica de sua verdade e fidelidade.

Assim, a revelação divina, orientada escatologicamente, torna a história possível e real. Pois, a promessa, compreendida sob o signo de futuro, já é realização presente, abrindo um horizonte de possibilidades e conduzindo a uma esperança maior.

Ora, se Deus se revela e se faz presente na história sob a modalidade da promessa - e a ação de Deus na história se realiza sob o signo da promessa -, isso torna a esperança escatológica viável, torna também viável a mudança do mundo em direção ao futuro, e a própria esperança escatológica se torna a alma da história.

No evangelho do evento de Cristo, esse futuro já se tornou presente nas promessas de Cristo. $O$ evangelho anuncia a irrupção presente desse futuro e vice-versa, 0 futuro é anunciado nas palavras empenhadas pelo evangelho. Por conseguinte, a pregação de Cristo está contida em uma revelação que encerra a proximidade do Senhor que vem. Dessa forma, ela torna "histórica" a realidade do ser humano e o engaja na história ${ }^{369}$.

\footnotetext{
${ }^{369}$ MOLTMANN, J. Teologia da esperança., pp.181-182.
} 
Com efeito, para Moltmann, não é apenas Deus que se revela na história sob a modalidade da promessa; a própria ressurreição se concebe sob a modalidade de promessa; e se ela é concebida sob a modalidade de promessa, 0 próprio Cristo ressuscitado deve ser entendido de modo diferente.

\section{2 .2}

\section{A ressurreição e a promessa escatológica}

Em Moltmann, Cristo Ressuscitado apenas anuncia o futuro de Deus para o mundo e renova a promessa escatológica de uma forma universal e insuperável. Daí a ação de Deus em relação ao Cristo crucificado aparece somente na ressurreição, pois é aí que Deus se revela como Aquele que vem e confirma a sua promessa de uma nova criação escatológica como futuro desta história. Assim, se Jesus Ressuscitado é primícias dos mortos, esta ação escatológica de Deus, que aparece como anúncio na ressurreição, deve ser entendida como a vida vindoura na ressurreição de todos os mortos e a vinda do Reino de Deus, ou seja, é a própria vida do mundo que há de vir.

Neste sentido, Moltmann tem uma compreensão fortemente funcional sobre o próprio mistério de Cristo. Pois na sua ressurreição Cristo tem a função de confirmar a promessa universal de Deus. Contudo, o cumprimento desta promessa está projetado para o futuro e só poderá ser apreendido na esperança, da mesma forma que o futuro de Cristo ainda está em aberto. Assim, a própria fé deve converter-se em esperança, visto que fora da promessa ela não possui nada em que se sustentar. Deste modo, podemos afirmar que o único objeto desta esperança é Deus mesmo, pois é Ele quem age na ressurreição de Cristo e quem a opera, e consequentemente o futuro do Cristo também está em suas mãos. Ora, se é assim, a cristologia é também reduzida a um papel funcional para a teologia, e fatalmente o problema da divindade de Jesus em Moltmann é praticamente irrelevante.

Outrossim, a questão da continuidade da pessoa de Jesus Cristo na cruz e na ressurreição está associada a esta maneira funcional de compreender o mistério de Cristo. E aí Moltmann discorda de Pannenberg, pois para o primeiro a cruz não pode ser desprezada em uma interpretação cristológica da ressurreição, haja vista que é a cruz o elemento que destaca o fator de descontinuidade. Entretanto, é mister questionar-se se é verídico que, no evento da ressurreição, o ponto de identidade não se situa na pessoa de Jesus, mas fora dele, em Deus que cria ex nihilo a vida e o ser novo. A despeito disto poder ser caracterizado como 
manifestação da própria fidelidade de Deus, continua determinado de maneira decisiva pela expectativa escatológica de uma recriação total, de uma creatio nova ex nihilo. Todavia, sendo assim, a continuidade e a identidade da pessoa de Cristo na cruz e na ressurreição não podem mais ser mantidas, visto que Cristo ressuscitado seria, pela ação escatológica de Deus, um ser totalmente novo. Em suma, a questão está no horizonte da promessa e da esperança escatológica, horizonte, que por sua vez, é constitutivo para a crstologia da ressurreição.

\begin{abstract}
Com efeito, a ressurreição de Cristo não está ligada à categoria do ocasional-novo, mas à categoria da expectativa, do escatológico-novo. O escatológico-novo da ressurreição de Cristo, por seu lado, se apresenta como o novum ultimum, tanto do que a sempre repetida realidade tem de igual como do que é relativamente desigual nas possibilidades históricas novas. Pelo simples alargamento do método de consideração histórica, por meio da admissão da contingência, a realidade da ressurreição ainda não se torna visível nem compreensível. Não é por meio de uma possível superação da forma antropocêntrica da analogia histórica que esta recebe um caráter teológico. Somente quando a totalidade do universo histórico é demonstrada, juntamente com a contingência e a continuidade, como algo que em si mesmo não é necessário, mas contingente, começa a ficar visível e inteligível aquilo que é pregado no querigma como o escatológico-novo da ressurreição de Cristo. A ressurreição de Cristo não significa uma possibilidade do mundo e de sua história, mas uma nova possibilidade de mundo, de existência e de história em sua totalidade. Somente quando o mundo for entendido como criação contingente (Contingentia mundi), a partir da liberdade de Deus e ex nihilo, a ressurreição de Cristo se torna inteligível como nova creatio. (...) Pela ressurreição de Cristo não se entende um processo possível dentro da história universal, mas uma realidade escatológica da história universal ${ }^{370}$.
\end{abstract}

\title{
5.2.3 \\ Cristologia da Cruz
}

A cristologia da cruz em Moltmann possui uma perspectiva complementar em relação à cristologia da ressurreição. Este tema é melhor desenvolvido na sua obra O Deus Crucificado, onde ele elabora uma interpretação cristológica da cruz de Jesus. Precisamente por ter uma perspectiva complementar, a referida obra não abandona as linhas fundamentais da Teologia da Esperança. Antes leva o próprio evento da ressurreição nos reportar à crucificação, visto que esta é causa eficiente daquela, ou seja, a cruz encontra na ressurreição o seu próprio fim.

Apesar da estreita ligação que há entre Teologia da Esperança e O Deus Crucificado, esta segunda obra traz algumas reformulações, progressos e retificações de explicações da obra anterior. Sobretudo no que diz respeito à maior atenção que Moltmann dá à história concreta de Jesus, e consequentemente à sua humanidade, isto é, à sua atividade pública, ao seu comportamento, à sua

\footnotetext{
370 Ibid., pp.229-230.
} 
mensagem, à sua reivindicação de autoridade e principalmente ao seu relacionamento com Deus, particularmente importante porque o que conhecemos deste mesmo relacionamento com a divindade, nós o conhecemos a partir de sua humanidade.

Tal reflexão sobre o Jesus terrestre torna-se mister no pensamento de Moltmann precisamente por causa do fim de Jesus na cruz, para onde converge toda a história de vida de Jesus. Assim, o itinerário histórico de Jesus deve ser visto como a sua caminhada para cruz, já que a sua morte é a consequência de todo o seu agir. Contudo, o nosso teólogo protestante não põe a problemática de modo regressivo, ou seja, retornando aos dados biográficos deste itinerário de Jesus, ao contrário, todos os dados históricos são considerados e avaliados teologicamente. Com efeito, este mesmo itinerário histórico de Jesus para a cruz é marcado por três atitudes fundamentais e características, que na mesmacruz aparecem com um significado ímpar e a fundamentam cristologica e teologicamente.

a) A relação de Jesus com a lei do Antigo Testamento: Jesus opõe a justiça pela fé à justiça pelas obras da lei, e o evangelho e a promessa à lei. Assim, acaba por ser considerado um blasfemo pelos judeus. A cruz leva essa tensão ao seu ponto mais alto e o leva ao mesmo tempo a uma decisão. Pois se o movimento de Jesus tivesse acabado com a morte na cruz, a lei teria levado vitória sobre o Deus da promessa. Assim, aqui tem-se a percepção de que a pregação de Jesus não pode ser desvinculada de sua pessoa, visto que em Jesus pessoa e causa são idênticas. Jesus, acusado de blasfêmia morre em decorrência da sua causa, do seu movimento pelo direito de Deus no processo entre lei e a promessa.

b) A relação de Jesus com o poder político: se por um lado Jesus se afasta dos revolucionários de sua época, como por exemplo os zelotes, por outro, a sua crucificação é sem dúvida a pena pela sua revolta política. A forte influência política na história de Jesus encontra suas raízes no seu próprio engajamento pela justiça de Deus neste mundo, ou seja, a superação de todo legalismo, a recusa do pensamento que opõe amigos e inimigos, a rejeição de todo poder profano sobre a soberania exclusiva de Deus.

Em tudo isso Jesus questiona os fundamentos religiosos e políticos tanto do poder israelita como do poder romano, e como consequência última de seus atos, morre na cruz como rebelde político, por se autodeclarar rei dos judeus e por isso inimigo de César. 
Aqui podemos perceber uma forte dimensão política que decorre da fé cristã. Pois se Jesus morreu na cruz por motivos também políticos, a confissão de fé em Cristo e a própria cristologia adquirem uma dimensão pública e social. Neste sentido, uma teologia da libertação tem seu fundamento no engajamento radical de Jesus em favor da soberania de Deus, a única legítima; e se ela é a única legítima, todas as outras que se impõem pela força e opressão são ilícitas. Assim, a atenção especial pelo direito das vítimas, como diria Sobrino, acaba por ocupar o núcleo da questão, assim como a preocupação em lutar contra toda justificação religiosa da soberania política e dos estados sociais reinantes. Com efeito, é na história e particularmente na história cristã que a cristologia da cruz deve ser entendida politicamente, visto que é sempre na história que o cristão deve combater as forças tiranas deste mundo sob o signo da cruz em que Jesus foi pregado como subversivo.

\subsection{4}

\section{Cristologia política}

Com efeito, é a partir desta lógica, que vimos no ponto anterior, que podemos falar de uma cristologia política em Moltmann, que por sua vez está em profunda unidade com a sua cristologia escatológica. Pois, ao passo que a cristologia escatológica procura fundamentar a esperança universal na história em virtude da promessa, a cristologia política procura formular em concreto a transformação exigida do mundo em função da vinda de Deus. Assim, Moltmann explora os elementos presentes na compreensão teológica da cruz.

Para o autor, a soberania do Cristo crucificado por motivações políticas possui como uma de suas chaves de leitura a libertação em relação às formas de poder, que oprimem e controlam os homens tornando-os apáticos, e a evacuação das religiões políticas que sustentam as referidas formas de poder. A consumação do Reino deve, neste sentido, segundo o Apóstolo Paulo, destruir todo poder tirano e suprimir as apatias e as alienações que lhes são equivalentes. Assim, os cristãos hão de procurar antecipar o futuro de Cristo na medida em que lhe for possível, de modo que toda dominação seja destruída e de par em par seja construída a vida política de cada um ${ }^{371}$.

Com efeito, o retorno à cruz livra a atividade histórica do cristão do vazio e da falta de plano e objetivo, pois a prática política da fé adquire agora um direcionamento claro e distinto: a promessa escatológica.

\footnotetext{
${ }^{371}$ MOLTMANN, J. O Deus crucificado., p.406.
} 
Por fim, cabe aqui apontar um último elemento da história de Jesus, isto é, a sua relação especial com Deus, a quem chama de Pai; relação que adquire na cruz a sua expressão mais elevada e plena. Já advertimos que para Moltmann há uma identificação total da pessoa de Jesus com a sua causa. Pois bem, esta união indissolúvel da causa própria de Deus com Jesus e a sua pregação, permite-nos compreender o seu sofrimento interior, um sofrimento essencialmente humano, bem como a índole peculiar e o significado teológico de sua morte.

Jesus não vivia como uma pessoa privada, algo que só foi feito dele na apresentação histórica liberal do século XIX, mas, até onde sabemos pelas fontes, ele vivia como uma pessoa pública sustentada pela proximidade de seu Deus e Pai para o Reino vindouro deste 372 .

\section{3 \\ Paul Tillich}

Passemos agora ao esboço cristológico do filósofo e teólogo protestante de origem alemã-estadunidense Paul Tillich, que em suas considerações sobre o dogma cristológico de Calcedônia começa por abordar a crítica sobre a utilização de termos gregos na elaboração do dogma cristológico.

Paul Tillich alenta para o fato de que o problema propriamente cristológico só começou quando as pessoas tomaram consciência de sua condição existencial e se questionaram se sua condição poderia ser superada mediante um novo estado da realidade. Em suma, é a busca pelo Novo Ser ${ }^{373}$ o pano de fundo sobre o qual se desdobra o dogma cristológico. Assim, é a partir daí que a tarefa dogmática da igreja dos primeiros séculos passou a focar na elaboração do dogma cristológico. Ele recorda que os fundamentos para a criação de uma cristologia são fruto do modo como os escritores do Novo Testamento aplicaram símbolos a

\footnotetext{
372 lbid., 192.

${ }^{373}$ Em TILLICH, P.Teologia Sistemática., o autor faz uma explanação sobre o referido Novo Ser, de modo que podemos resumir a mesma com as suas próprias palavras: Conforme o simbolismo escatológico, o Cristo é aquele que traz o novo éon. Quando Pedro chamou Jesus de "o Cristo", esperava que por sua mediação, se produzisse a vinda de um novo estado de coisas. Esta expectativa está implícita no título "Cristo". Mas ela não se realizou de acordo com as expectativas dos discípulos. Tanto na natureza como na história, nada mudou, e aquele de quem se esperava que fosse trazer o novo éon acabou sendo destruído pelos poderes do velho éon. Isso significava que os discípulos teriam que ou aceitar o colapso de sua esperança, ou então transformar radicalmente seu conteúdo. Eles foram capazes de escolher a segunda alte rnativa, pela identificação do ser de Jesus, o sacrificado, com o Novo Ser. Nos textos sinóticos, o próprio Jesus combinou a reivindicação messiânica com a aceitação de uma morte violenta. Mas estes mesmos textos mostram que os discípulos resistiram a esta combinação. Só as experiências que nos são descritas como Páscoa e Pentecostes criaram neles a fé no caráter paradoxal da reivindicação messiânica. Foi Paulo quem ofereceu a moldura teológica em que foi possível entender e justificar este paradoxo. Uma forma de abordar a solução do problema consistiu em estabelecer a diferença entre primeirae segunda vinda, o retorno glorioso do Cristo. No período entre a primeira e a segunda vinda, o Novo Ser está presente em Cristo. Ele é o Reino de Deus. Nele se cumpre, em princípio, a expectativa escatológica. Aqueles que participam nele participam do Novo Ser, embora sob as condições da situação existencial e, portanto, só de modo fragmentário e por participação (pp.407-408).
} 
Jesus, a quem passaram a chamar de "Cristo". Muitos foram os símbolos aplicados a Jesus, tais como: Filho do Homem, Filho de Deus, o Cristo, o Logos. Esta prática, por sua vez, levou a igreja primitiva a interpretar os símbolos cristológicos a partir dos termos conceituais que a filosofia grega lhes proporcionava.

\begin{abstract}
O símbolo do Logos foi o que melhor se adaptou a este propósito, porque, por sua própria natureza, é um símbolo conceitual cujas raízes são tanto religiosas quanto filosóficas. Consequentemente, a cristologia da igreja primitiva foi uma cristologia do Logos. É injusto criticar os Pais da Igreja por terem usado conceitos gregos. Não dispunham de outras expressões conceituais para o encontro cognitivo do ser humano com seu mundo. Se esses conceitos eram ou não adequados para a interpretação da mensagem cristã, segue sendo uma pergunta permanente na teologia. Mas é um erro rejeitar a priori o uso dos conceitos gregos pela igreja primitiva, pois não havia outra alternativa ${ }^{374}$.
\end{abstract}

Todas as outras declarações doutrinárias, sejam de caráter trinitário, pneumatológico, antropológico, são pressupostos ou fruto do dogma cristológico. A própria confissão de que Jesus é o Cristo é a base de toda a cristologia. Com efeito, as críticas ao dogma cristão são sempre em última análise de índole cristológica. Algumas dessas críticas, ou verdadeiramente ataques visam a substância divina ou humana de Jesus, ou a confissão batismal, ou ainda o uso de conceitos gregos.

Tillch afirma que muitas das críticas ao dogma cristológico e ao dogma cristão como um todo não existiriam se os seus críticos percebessem que os dogmas não surgem por motivos especulativos, embora o forte desejo por conhecer esteja sim presente e muito contribua para a formação dos dogmas. Mas eles são verdadeiramente doutrinas protetoras que têm como objetivo primordial preservar a substância da mensagem cristã contra distorções provindas tanto do interior da igreja como de fora dela.

\begin{abstract}
Se entendermos isto e reconhecermos que o uso do dogma para fins políticos é uma distorção demoníaca de seu sentido original, podemos, sem temer consequências autoritárias, atribuir um sentido positivo ao dogma em geral e ao dogma cristológico em particular. Mas então deveríamos formular duas perguntas bastante diferentes: até que ponto o dogma conseguiu reafirmar o sentido original da mensagem cristã contra efetivas e potenciais distorções? E até que ponto foi exitosa a conceitualização dos símbolos que expressam a mensagem cristã? Enquanto a resposta à primeira pergunta é claramente positiva, a resposta à segunda é francamente negativa. O dogma cristológico salvou a igreja, mas o fez com instrumental conceitual muito inadequado ${ }^{375}$.
\end{abstract}

O referido instrumental é considerado por Tillich como inadequado porque se tornou, em certa medida, incapaz de expressar a mensagem do que Tillich

\footnotetext{
374 lbid., p.426.

375 lbid., p.427.
} 
chama de Novo Ser em Jesus como o Cristo. Contudo, se por um lado isto é verdade, por outro, tal inadequação também provém dos conceitos gregos, que a despeito do seu conceito universal, são dependentes de uma religião específica e condicionada pelas imagens dos deuses Apolo e Dionísio ${ }^{376}$.

Com efeito, a crítica de Tillich difere bastante da crítica formulada por muitos outros teólogos, entre os quais Adolf Hanarck, que afirmava que o uso de conceitos gregos pela igreja primitiva acabava por intelectualizar o evangelho, 0 que seria uma atitude essencialmente equivocada. Ora, a base de tal raciocínio destes teólogos era a afirmação de que a filosofia grega, tanto clássica quanto helenística, era intelectualista por natureza, o que hoje é sabidamente falso. Pois tanto no período arcaico quanto clássico, a filosofia possuía uma importância existencial, a semelhança do que ocorria na tragédia e nos cultos de mistério. Assim, para Tillich, Sócrates, Zenão, Plotino, os estóicos e os neoplatônicos não podem ser considerados intelectualistas, pois todos apenas buscavam apaixonadamente o imutável tanto no campo teórico, quanto moral e ainda religioso; contudo através de um instrumental cognitivo. As próprias escolas filosóficas da Antiguidade não podem ser consideradas intelectualistas, pois elas se organizavam como comunidades cultuais, identificando o termo "dogma" com suas percepções mais básicas, afirmando a autoridade inspirada de seus fundadores e exigindo de seus adeptos a adesão às doutrinas mais fundamentais.

Para Tillich, não é por se utilizar de conceitos gregos que o evangelho será intelectualizado, pode ser sim helenizado, mas não necessariamente intelectualizado. Na verdade, o dogma cristológico para Paul Tillich possui uma forte índole helênica, até mesmo porque a missão evangelizadora da lgreja se dá no mundo helênico. Assim, para fazer uso de uma linguagem mais contemporânea, para evangelizar a cultura, no caso helênica, a lgreja precisou usar as formas de vida e de pensamento helenistas, que provenientes de fontes diversas, acabavam por se fundir no último período da Antiguidade. Três destas fontes foram de capital importância para a igreja cristã. São elas: os cultos mistéricos, as escolas filosóficas e o estado romano.

O cristianismo adaptou-se a todas elas e se tornou um culto de mistério, uma escola filosófica e um sistema legal, sem deixar de ser uma assembleia baseada na mensagem de que Jesus é o Cristo. Permaneceu sob as formas helenistas de vida e de pensamento. Não se identificou com nenhuma dela, mas transformou-as e continuou crítica até mesmo em relação à sua transformação. Apesar de longos

\footnotetext{
376 lbid.
} 
períodos de tradicionalismo, a igreja foi capaz de elevar-se a momentos de autocrítica e reconsiderar as formas a que se havia adaptado ${ }^{377}$.

Ora, é sabido que o dogma cristológico faz uso de conceitos gregos. Mas estes mesmos conceitos já tinham passado por uma transformação helenizante na era helenista; é o que aconteceu com o conceito de Logos. Porém, esses mesmos conceitos também passaram por um forte processo de cristianização. Todavia, a cristianização destes conceitos acabou por gerar sérios problemas para a teologia cristã, haja vista que nem sempre a formulação dogmática conseguia de fato cumprir com o seu objetivo, ou seja, afirmar que Jesus é verdadeiramente o Cristo frente às distorções pertinentes a este assunto, e afirmar tal verdade de fé com expressões conceituais claras capazes de comunicar esta verdade. Foi o que aconteceu em meados do século VI na recepção do Concílio de Calcedônia, quando mudanças semimonofisitas se introduziram na fórmula calcedoniana.

\begin{abstract}
Um exemplo de inadequação da forma conceitual é a própria fórmula de Calcedônia. Quanto à intenção e propósito, ela foi fiel ao sentido genuíno da mensagem cristã. Ela preservou o cristianismo de uma completa eliminação da imagem de Jesus como o Cristo, no que se refere à participação do Novo Ser no Estado de alienação. Mas o fez - e não poderia tê-lo feito de outro modo dentro do quadro conceitual em que se movia - mediante uma acumulação de poderosos paradoxos. Ela foi incapaz de dar uma interpretação construtiva, embora esta fosse a razão da introdução original dos conceitos filosóficos. A teologia não deveria culpar seu instrumental necessariamente conceitual quando o fracasso se deve a uma piedade deteriorada, nem deveria atribuir as inadequações do instrumental conceitual a uma debilidade religiosa. Tampouco deveria tentar desfazer-se de todos os seus conceitos filosóficos, pois isto equivaleria a desfazer-se de si mesma! Frente aos conceitos que utiliza, a teologia deve ser live para continuar a utilizá-los ou para dispensálos. Deve permanecer livre de toda confusão entre a forma conceitual e a substância dos mesmos, e deve permanecer live para expressar esta substância por meio de quaisquer instrumentos que demonstrem ser mais adequados que aqueles oferecidos pela tradição eclesiástica ${ }^{378}$.
\end{abstract}

\title{
5.3.1
}

\section{Os riscos presentes no desenvolvimento do dogma cristológico}

Para Paul Tillich a afirmação de que Jesus é o Cristo traz consigo dois riscos que acabam por ameaçar toda exposição cristológica. Tais riscos são verdadeiramente frutos da tentativa de interpretar conceitualmente a referida afirmação de que Jesus é o Cristo. Ambos os riscos são de negação: a negação do caráter "de Cristo" de Jesus como o Cristo ou do caráter "de Jesus" do Jesus como o Cristo. "A cristologia sempre deve trilhar o caminho estreito entre estes

\footnotetext{
377 lbid., p.428.

378 lbid., pp.428-429.
} 
dois abismos, sabendo que jamais terá êxito completo, pois está tocando o mistério divino, que permanece um mistério inclusive em sua manifestação" 379 .

Usando termos bastante clássicos, Tillich afirma que o grande problema aí consistia em como expressar a união de uma natureza plenamente humana com uma natureza plenamente divina. Pois qualquer redução de sua natureza humana privaria o Cristo de uma participação plena nas condições da existência humana. Assim como qualquer redução de sua natureza divina privaria o Cristo de sua plena vitória sobre o que Tillich chama de alienação existencial ${ }^{380}$. Trata-se de uma questão mal resolvida, haja vista que a doutrina das duas naturezas em Cristo formula a pergunta correta, mas lança mão de instrumental conceitual equivocado. Para Tillich, a inadequação básica está no termo "natureza", que ao ser aplicado ao ser humano, torna-se ambíguo e ao ser aplicado a Deus, torna-se equivocado. É o que ocorre com os concilios de Nicéia e Calcedônia, que a despeito de sua verdade substancial e de seu significado histórico, teriam inevitável e definitivamente fracassado neste sentido, segundo Tillich.

\begin{abstract}
A decisão de Nicéia defendida por Atanásio como uma questão de vida e morte para a igreja, tornou inadmissível a negação do poder divino do Cristo na revelação e na salvação. Na terminologia da controvérsia nicena, o poder do Cristo é o poder do Logos divino, o princípio da automanifestação divina. Isto suscitou a questão de se o Logos é igual em poder divino ao Pai, ou menor do que ele. Se optamos pela primeira resposta, parece desaparecer a diferença entre Pai e Filho, como ocorre na heresia sabeliana. Se nos decidimos pela segunda resposta, o Logos, mesmo que se diga que é a maior de todas as criaturas, não deixa de ser uma criatura e, como tal, é incapaz de salvar a criação, como acontece na heresia ariana. Só o Deus que é realmente Deus, e não um semideus, pode criar o Novo Ser. O termo que devia expressar essa idéia era homousios, "de igual essência". Mas, neste caso, perguntarem os semi-arianos, como é possível haver uma diferença entre o Pai e o Filho? E não se torna completamente ininteligível a imagem do Jesus histórico? Foi difícil para Atanásio e seus seguidores mais diretos (por exemplo, Marcelo) responder a estas perguntas ${ }^{381}$.
\end{abstract}

Já Calcedônia, apesar das deficiências de sua fórmula, legou importante vitória, a partir do momento que impediu que se eliminasse o caráter "de Jesus" do Cristo, a despeito das bem sucedidas tentativas que surgiram mais tarde no Oriente com os concílios de Constantinopla, que queriam explicitar a decisão de Calcedônia a partir da linha de Cirilo. Em suma, malgrado as deficiências das fórmulas, as decisões de Nicéia e Calcedônia preservaram tanto o caráter "de Cristo" quanto o "de Jesus" no evento de Jesus como o Cristo. E este é o juízo que embasa o esboço cristológico de Tillich.

\footnotetext{
379 lbid., p.429.

380 lbid.

381 lbid., pp.429-430.
} 


\subsection{2}

\section{A cristologia na atualidade}

Para Tillich, cabe à teologia protestante aceitar a tradição católica na medida em que esta se baseia na substância das duas grandes decisões da Igreja dos primeiros séculos (Nicéia e Calcedônia), mas também deve procurar novas maneiras em que se possa expressar a substância cristológica de tempos passados. Neste sentido, é preciso ter uma atitude crítica em relação às cristologias ortodoxas e liberais dos últimos séculos da teologia protestante.

O desenvolvimento da ortodoxia protestante, tanto em seu período clássico quanto
em suas reformulações posteriores, evidenciou a impossibilidade de uma solução
compreensível do problema cristológico em termos da terminologia clássica. O
mérito do liberalismo teológico consistiu em demonstrar, através de investigações
histórico-críticas - por exemplo, na História do dogma de Harnack - as inevitáveis
contradições e absurdos em que desembocam todas as tentativas de resolver o
problema cristológico em termos da teoria das duas naturezas. Mas este mesmo
liberalismo contribuiu pouco para a cristologia em termos sistemáticos ${ }^{382}$.

Thillich defende a posição de que o liberalismo, ao afirmar que "Jesus não pertence ao evangelho proclamado por Jesus", destruiu a índole crística que possui o evento "Jesus, o Cristo". O teólogo protestante recorda que até Albert Schweitzer, entre outros historiadores, destacou a índole escatológica da mensagem de Jesus e sua auto interpretação como núcleo do esquema escatológico. Porém, não fez uso deste elemento em sua cristologia, mas o destacou como "complexo de uma imaginação estranha e como algo próprio de um êxtase apocalíptico"383.

Neste sentido, a índole crística do evento "Jesus, o Cristo" foi diluída em sua indole "de Jesus". Contudo, Tillich defende a teologia liberal dizendo que não é justo identificá-la com o arianismo, visto que a sua imagem de Jesus não é a de um semi-deus, mas a imagem de um homem em quem Deus se manifestou de um modo ímpar. Todavia, não se trata da imagem de um homem cujo ser é o Novo Ser e que foi capaz de superar a alienação universal. Assim, o teólogo alemãoestadunidense compreende que nem o método ortodoxo e nem o liberal da teologia protestante são eficazes para a tarefa cristológica que se impõe à igreja protestante da atualidade ${ }^{384}$.

Paul Tillich também recorda que para a igreja primitiva a cristologia era uma tarefa existencialmente indispensável. Contudo, o seu critério último é soteriológico, ou seja, condicionado pela questão da salvação. Ele faz menção ao

\footnotetext{
382 lbid., p.432.

383 Ibid.

384 Ibid., p.433.
} 
antigo pensamento patrístico segundo o qual quanto mais grandioso for o que afirmamos do Cristo, maior será a salvação que podemos esperar dele. Entretanto, Tillich adverte que há diferenças quando se procura definir o significado de "grandioso" a respeito de Cristo. Os monofisitas, desde a igreja primitiva até a atualidade, compreendem que só se pode dizer algo de grandioso sobre Cristo a partir do momento que sua humilhação, ou seja, sua participação na finitude e tragédia é aniquilada por sua grandeza, ou por seu poder de vencer a alienação existencial.

\begin{abstract}
Chamamos de "alta" cristologia esta ênfase na "natureza divina". Mas por mais grandiosos que sejam os predicados acumulados sobre o Cristo, o resultado sempre será uma cristologia de baixo valor, porque elimina o paradoxo e o substitui por um milagre sobrenatural. E a salvação só pode provir daquele que participou plenamente na condição existencial do ser humano, não de um Deus que caminha sobre a terra e é "diferente de nós em todos os aspectos"385.
\end{abstract}

Assim, segundo Tillich, a verdadeira alta cristologia é traduzida pelo princípio protestante segundo o qual Deus está tão próximo do mais baixo quanto do mais alto, e precisamente por isso, a salvação não pode de modo algum consistir na transferência do ser humano do mundo material para um mundo meramente chamado espiritual. Com efeito, é justamente a tentativa de cristologia monofisita acima explicitada que deveria ser julgada a partir deste princípio protestante.

\title{
5.3.3
}

\section{A natureza divina e a natureza humana}

Paul Tillich compreende as expressões "natureza humana" como ambígua e "natureza divina" como totalmente equivocada. Por "natureza humana" pode-se compreender a natureza essencial ou criada do ser humano, ou indicar a sua natureza existencial ou alienada, e ainda pode significar a natureza do ser humano na união ambígua das duas. Neste sentido, para Tillich, quando afirmamos que Jesus como o Cristo tem a "natureza humana", devemos dizer que ele tem uma natureza humana plena. Contudo, se compreendemos "natureza humana" como acima posto e a aplicamos a Cristo, ela torna-se ambígua. Assim, teoriza o autor:

Se aplicamos o termo "natureza humana" a Jesus como o Cristo, devemos dizer que ele tem uma natureza humana completa no primeiro sentido da palavra: pela criação, ele é liberdade finita, como todo ser humano. Quanto ao segundo sentido de "natureza humana", devemos dizer que Jesus possui a natureza existencial do ser humano como uma possibilidade real, mas de tal forma que a tentação - que é a possibilidade - sempre é superada na unidade com Deus. Disso se segue que, no seu terceiro sentido, a natureza humana deve ser atribuída a Jesus na medida 
em que ele se encontra imerso nas ambiguidades trágicas da vida. Sob essas circunstâncias, somos obrigados a descartar totalmente a expressão "natureza humana" em relação a Cristo e a substituí-la por uma descrição da dinâmica de sua vida $^{386}$.

Se a aplicação da expressão "natureza humana" a Cristo é ambígua, a aplicação da expressão "natureza divina", como já dito, é inadequada. E para chegar a esta conclusão, Tillich recorda que na antiguidade cristã o termo "natureza" era um conceito que abrangia tudo; os deuses, o ser humano e todos os outros seres que constituem o universo e pertencem à natureza, ou seja, àquilo que se desenvolve por si mesmo. Ora, mas se a expressão "natureza divina" significa aquilo que faz Deus ser Deus, então o significado de "natureza divina" coincide com o de essência. Porém, Deus não tem uma essência separada da existência, visto que ele está muito acima da essência e da existência. Ele é Aquele que é, qualitativa e infinitamente transcendente a tudo o que existe, eterno em si mesmo. A este conceito, Tillich recorda que se poderia chamar de "natureza essencial de Deus". Logo, o autor quer afirmar que para Deus é essencial transcender toda essência, pois Ele é eternamente criativo, de modo que através de si mesmo Ele cria o mundo e através do mundo a si mesmo. Sendo assim, não existe natureza divina que possa ser abstraída de sua criatividade eterna, o que torna a expressão "natureza divina" questionável e impossível de ser aplicada a Cristo.

\begin{abstract}
Esta análise nos revela que a expressão "natureza divina" é questionável e não pode ser aplicada a Cristo de modo significativo, pois o Cristo (que é Jesus de Nazaré) não está além de essência e existência. Se estivesse, não poderia ser uma vida pessoal que viveu durante um período limitado de tempo, nasceu e morreu, foi um ser finito, sofreu tentações e se viu tragicamente imerso na existência. A afirmação de que Jesus como o Cristo é a unidade pessoal de uma natureza divina e uma natureza humana deve ser substituída pela afirmação de que em Jesus como o Cristo a unidade eterna de Deus e ser humano se tornou realidade histórica ${ }^{387}$.
\end{abstract}

Assim Tillich, por considerar o conceito "natureza divina" inadequado, acaba por substituí-lo pelos conceitos "unidade eterna Deus-ser humano" ou "Eterno Deus-Humanidade", conceitos relacionais que fazem da imagem dinâmica de Jesus como o Cristo, uma imagem compreensível.

Substituímos o conceito inadequado de "natureza divina" pelos conceitos "unidade eterna Deus-ser humano" ou "Eterno Deus-Humanidade". Estes conceitos substituem uma essência estática por uma relação dinâmica. A singularidade desta relação de forma alguma é diminuída por seu caráter dinâmico. O que acontece é que, ao eliminar o conceito das "duas naturezas" - naturezas que permanecem uma ao lado da outra como blocos e cuja unidade não pode ser absolutamente entendida

\footnotetext{
386 lbid., pp.433-434.
}

387 lbid., p.434. 
- abrimo-nos a conceitos relacionais que tornam compreensível a imagem de Jesus como o Cristo ${ }^{388}$.

Nestas expressões de caráter relacional, sugeridas por Tillich, temos aí acrescentada a palavra "eterno". Pois "eterno" indica o pressuposto geral do evento único de Jesus como o Cristo. Tal evento não aconteceria sem uma unidade eterna entre Deus e o homem dentro da vida divina. E por sua vez, esta unidade, em estado de pura essencialidade ou potencialidade, pode realmente ser atualizada a partir da liberdade finita. Neste mesmo evento único de Jesus como - Cristo, esta unidade acontece contra a ruptura existencial. A índole desta unidade foi manifestada de maneira concretanos evangelhos. Contudo, para Paul Tillich as conceituações abstratas da natureza desta unidade são tão impossíveis quanto às investigações psicológicas sobre sua índole. $O$ que de fato pode-se afirmar é que trata-se de uma comunhão entre Deus e o núcleo de uma vida verdadeiramente pessoal, comunhão que, por sua vez, "determina todas as expressões desta vida e que na alienação existencial resiste a todas as tentativas de desfazê-la"389.

Entretanto, diante desta argumentação de Tillch, o próprio autor adverte em relação a uma questão que aí surge e que é preciso esclarecer: se a substituição da teologia das duas naturezas por conceitos dinâmico-relacionais não eliminaria a ideia de "encarnação". O teólogo questiona: "Um conceito relacional não representa o retorno de uma cristologia de encarnação para uma cristologia de adoção?"390 Ora, tanto a cristologia encarnacional quanto a adopcionista têm raízes bíblicas, o que lhes dá um destaque importante na teologia cristã. No entanto, para Tillich este não é o único elemento que ambas as cristologias têm em comum. O teólogo defende que uma implica a outra. Ele recorda que o adopcionismo afirma que Deus, através do seu Espírito, adotou o homem Jesus de Nazaré como Messias, o que sugere a questão: Por que precisamente Jesus? Já que tantos outros judeus se proclamaram ou foram tidos como Messias. Tal questionamento nos coloca diante da polaridade de liberdade e destino que possibilitou a unidade ininterrupta entre ele (Jesus) e Deus. Com efeito, o relato evangélico do nascimento virginal de Jesus posiciona esta unidade ainda no início de sua vida e também o faz remontar aos seus antepassados. Assim, a doutrina do Logos que se fez carne indica a dimensão eterna e aponta para a encarnação ${ }^{391}$.

\footnotetext{
${ }^{388} \mathrm{lbid}$

389 lbid., p.435.

$390 \mathrm{lbid}$

391 lbid.
} 


\begin{abstract}
A cristologia encarnacional era necessária para explicar a cristologia adocionista. Esta foi uma consequência necessária da outra. Mas a cristologia encarnacional tem idêntica necessidade da cristologia adocionista para alcançar sua plenitude embora nem sempre se tenha visto assim. Em si mesmo, o termo "encarnação" (como o termo "natureza divina") é adequado no paganismo. Já que os deuses pertencem ao universo, eles podem assumir com facilidade todas as formas do universo, e inúmeras metamorfoses são possíveis. Mas quando o cristianismo usa o termo "encarnação", ele tenta expressar o paradoxo de que aquele que transcende o universo aparece no universo e está sujeito às suas condições. Neste sentido, toda cristologia é uma cristologia encarnacional ${ }^{392}$.
\end{abstract}

Todavia, segundo Tillich, nesta concepção o significado de alguns termos pode oferecer dificuldades em vista de uma distinção dos mitos pagãos de transmutação. Assim, se o termo egeneto da expressão do evangelho de São João Logos sarx egeneto (a Palavra se fez carne) é demasiadamente acentuado, corre-se o risco de cair em uma mitologia da metamorfose, onde naturalmente se questiona como uma coisa que se tornou outra coisa pode continuar sendo a coisa que era. Teria o Logos desaparecido quando Jesus foi concebido no ventre de Maria? Absurdo? É precisamente neste ponto que Tillich afirma que o absurdo substitui o pensamento, e se pede à fé que aceite absurdos. Para o teógolo a encarnação do Logos não é uma metamorfose, mas sim sua plena manifestação numa vida pessoal.

\begin{abstract}
E a manifestação do Logos numa vida pessoal é um processo dinâmico que envolve tensões, riscos, perigos e a determinação pela liberdade bem como pelo destino. Este é o aspecto de adoção, sem o qual a encarnação tornaria irreal a imagem viva do Cristo. Ele estaria privado de sua liberdade finita, pois um ser divino transmutado não tem a liberdade de ser outra coisa senão divino e tampouco sofreria verdadeiras tentações ${ }^{393}$.
\end{abstract}

Tillich ainda recordaque o protestantismo favorece este tipo de pensamento:

\begin{abstract}
Ele não nega a ideia de encarnação, mas abandona suas conotações pagãs e rejeita sua interpretação supranaturalista. Assim como o protestantismo afirma a justificação do pecador, ele exige uma cristologia de participação do Cristo na existência pecadora, que implica, ao mesmo tempo, sua vitória sobre ela. O paradoxo cristológico e o paradoxo da justificação do pecador são um único e mesmo paradoxo - o paradoxo do Deus que aceita um mundo que o rejeita ${ }^{394}$.
\end{abstract}

Por fim, cabe-nos recordar que a concepção cristológica de Tillich se assemelha em vários aspectos à cristologia do grande teólogo e também filósofo protestante do século XIX Friedrich Schleiermarcher(+1834). Schleiermarcher em sua obra intitulada Glaubenslehre substitui a doutrina das duas naturezas pela doutrina de uma relação divino-humana. Aí ele fala de uma consciência de Deus em Jesus, cuja força ultrapassa a consciência de Deus que têm todos os outros

\footnotetext{
392 lbid.

393 lbid., p.436.

394 lbid.
} 
homens. Ele descreve Jesus como "a imagem original" (Urbild) daquilo que o ser humano é essencialmente antes da queda. A despeito das semelhanças entre as duas cristologias, elas não são iguais, mas parecidas. O próprio conceito de "Deus-Humanidade Essencial” tende para ambos os lados da relação em termos de eternidade. A expressão "unidade essencial entre Deus e ser humano" é de caráter ontológico, ao passo que a "consciência de Deus" de Schleiermacher possui caráter antropológico. A expressão "imagem original" (Urbild), utilizada em relação a Jesus como o Cristo, não possui a mesma implicação decisiva da expressão "Novo Ser", tão cara a Tillich ${ }^{395}$. "Imagem original" manifesta diretamente a transcendência idealista da verdadeira humanidade em relação à existência humana, enquanto em "Novo Ser" é decisiva a participação daquele que também é "imagem original".

O "Novo Ser" é verdadeiramente novo em relação à existência e à essência, quando consideramos que a essência permanece apenas como potencialidade. Já a "imagem original" continua imutável para além da existência. O "Novo Ser" participa da existência e a supera. Em suma, as diferenças estão no elemento ontológico. Contudo, tais diferenças, ao manifestar também diferentes pressupostos e consequências, não poderiam esconder o surgimento de problemas e soluções semelhantes quando a teologia protestante opta por um caminho que supera o binômio teologia clássica e teologia liberal. E esta é a situação em que se encontra a teologia protestante hoje ${ }^{396}$. 


\section{6 \\ Cristologia Calcedoniana Ortodoxa}

\section{1}

\section{Paul Evdokmov}

Paul Evdokimov (+1970) foi um teólogo ortodoxo de tradição russa que lecionou por muitos anos no renomado Instituto Ortodoxo São Sérgio de Paris. Autor de muitas obras, Paul Evdokimov continua sendo um dos teólogos ortodoxos mais lidos em todo mundo. Como um bom teólogo ortodoxo, em sua obra - herdeira da filosofia russa e da síntese neo-patrística -, teologia e espiritualidade são inseparáveis, e é precisamente esta propriedade de sua obra, que o faz hábil para transitar por várias áreas da teologia buscando um maior diálogo com a sociedade pós-moderna. Por sua relevância na produção teológica do século XX chegou a ser observador convidado do Concílio Vaticano II.

Paul Evdokimov não aborda propriamente a cristologia do Concilio de Calcedônia e nem faz um esboço cristológico preciso, até mesmo porque a investigação teológica ortodoxa e oriental não é tão fragmentária quanto a ocidental, mas sim holística, de maneira que a ciência teológica seja mais difusa, no sentido de que ela lança luz sobre outras áreas do conhecimento e seja até mesmo o elo entre elas. De modo que é muito comum na teologia ortodoxa uma associação entre teologia, espiritualidade, filosofia, literatura, estética, etc. Entretanto, a importância de Evdokimov no presente ensaio é devida exatamente porque sua reflexão teológica tem como ponto de partida a cristologia do Concílio de Calcedônia, ou seja, Deus se fez homem para deificar o homem. Contudo, em que sentido pode-se compreender e proclamar esta união do divino e do humano hoje? Ou melhor: como Paul Evdokimov a compreendeu e a proclamou? Para responder tal pergunta precisamos tomar consciência do outro pilar de sua reflexão: a perspectiva cristológica russa que, por sua vez, é inseparável da filosofia religiosa russa. 


\subsection{2}

\section{A cristologia russa nos séculos $X I X$ e $X X$}

Evdokimov, em claro objetivo de expressar a fé em seu contexto de modo acessível, debruça-se dobre a história da teologia percorrendo-a em seus diversos momentos de esforços para comunicar a fé cristã. Ele recorda que se na Idade Média a teologia acentuou fortemente o divino, no Renscimento este acento recaiu sobre o homem. São posturas teológicas extremas que carecem do devido equilíbrio teândrico para que se possa falar do humano pelo divino.

Em sua investigação teológica, Evdokimov percebe Leôncio de Bizâncio (+543), monge e teólogo, como um dos maiores defensores do credo de Nicéia, de modo que seu trabalho foi tão importante a ponto de influenciar a teologia cristã e a própria cultura medievais. Leôncio desenvolveu o princípio da enipostasia da natureza humana de Cristo no Verbo divino ${ }^{397}$. De maneira que a natureza humana de Cristo não ficou sem hypóstasis, porém, tornou-se hipostática no Lógos. Assim, para Leôncio de Bizâncio, duas realidades podem se unir de modo que suas naturezas distintas subsistam numa única pessoa, ou hypóstasis. "É a esta luz que ele contempla o mistério da encarnação. O Cristo é Filho de Deus, o Um da Trindade, e ele é Filho do Homem, o um de nós"398.

Para Evdokimov a supremacia da teologia russa no mundo ortodoxo remonta ao século XVI ${ }^{399}$. As escolas de Kiev e Moscou ${ }^{400}$, a partir do século XVII passaram a ser fortemente influenciadas pelo pensamento latino, o que provocou uma autonomia da teologia russa em relação à grega, malgrado a nítida tendência grega da escola de Moscou.

Já Filarete (+1867), metropolita de Moscou, é considerado por Evdokimov como a figura de maior relevância teológica do século XIX, devido a sua grandeza de testemunho e fidelidade à Tradição. Foi capaz de influenciar diretamente por quase cinquenta anos o destino da Igreja e do Estado. Segundo testemunho de Evdokimov, para Filarete não basta ter fé e guardá-la. A teologia, em seu conteúdo dogmático, deve ser vivida, é o que caracteriza o "conhecimento vivo" dos eslavófilos. "O cristianismo não é de modo algum um asilo de ignorância, mas a

\footnotetext{
${ }^{397}$ EVDOKIMOV, P. Le Christ dans la pensée russe., p.23.

398 lbid.

399 lbid., p.50.

${ }^{400}$ A escola de Kiev teve o metropolita Mogila (+1646) como seu grande iniciador em fins do século XVI e início do século XVII, foi a primeira escola teológica russa. Aí os ma nuais de dogmática eram escritos em latim até metade do séculoXIX. Já a escola de Moscou foi fundada em 1665 por Simeão Polocky.
} 
escola da Sabedoria de Deus, o que impõe a todos os fiéis o dever sagrado de teologizar (...)" 401 .

Em sua pesquisa, Paul Evdokimov reconhece a necessidade de se retornar à tradição patrística. E para ele o Padre Georges Florovsky (+1979) foi o primeiro a pregar esse retorno à tradição patrística. Tal retorno constitui virada decisiva na teologia ortodoxa do século XX. Frente aos problemas do mundo moderno, tornase mister elaborar um pensamento cristão integral. Daí a necessidade de uma síntese do ensinamento dos Padres da Igreja. Para Evdokimov, o retorno à teologia patrística, longe de ser uma limitação ou imitação, é uma redescoberta experimental que possibilita um avanço para a teologia ${ }^{402}$.

Para Evdokimov, Vladimir Lossky (+1958) é o primeiro teólogo a publicar obra em perspectiva de síntese neo-patrística, em A Teologia Mística da Igreja do Oriente, de 1944. Aí o autor relaciona a dimensão apofática e catafática numa única via, contudo, em direções opostas. "Deus desce em direção a nós em suas energias que o manifestam. Nós subimos em direção a Ele, nas uniões nas quais Deus permanece incognoscível por natureza" ${ }^{403}$. Neste sentido, o sopro de vida que o ser humano recebeu no ato criativo de Deus, mostra a intimidade da graça divina para com o humano, predestinado à Deus.

Entretanto, segundo Evdokimov, o ato criativo de Deus para o Padre Sérgio Bulgakov (+1944), tem a sua raiz no Cordeiro Imolado antes da fundação do mundo (Ap 13,8). O esboço teológico de Bulgakov, como bom teólogo ortodoxo, tem por base o dogma cristológico. Pois tudo parte do evento principal da encarnação: a Palavra se fez carne (Jo 1,14). "A humanidade criada deiforme à imagem de Deus é predestinada desde o começo a receber o Deus-Homem"404. Assim, Bulgakov destaca a dupla meta cristológica da definição de Nicéia: "Jesus Cristo, o Filho de Deus, gerado unigênito do Pai, isto é, da substância do Pai, (...) por causa de nós homens e da nossa salvação desceu e se encarnou, se enhumanou"405. Ainda segundo Evdokimov, Bulgakov compreende essa definição como a redenção da humanidade ${ }^{406}$, porque por causa de nós Ele se emhumanou. E é exatamente aí que consiste a deificação do ser humano ${ }^{407}$.

Todavia, a perspectiva cristológica na teologia russa dos séculos XIX e XX, nutre-se não somente das definições conciliares, mas é também influenciada pela

\footnotetext{
401 EVDOKIMOV, P. Le Christ dans la pensée russe., p.57.

402 lbid., p.57.

403 lbid., .p198.

${ }^{404}$ Ibid., p.182.

405 DS, no 125.

406 EVDOKIMOV, P. L'Orthodoxie., p.62.

${ }^{407}$ Id. Le Christ dans la pensée russe., p.179.
} 
filosofia religiosa que se produziu na Rússia neste período, de modo que teologia e filosofia se integram no que diz respeito à reflexão da realidade divina em Jesus e da realidade humana na história. E é isso o que veremos a seguir, pois tal confluência influencia fortemente o pensamento de Paul Evdokimov.

\subsection{3}

\section{A perspectiva filosófica na teologia russa dos séculos $\mathrm{XIX}$ e $\mathrm{XX}$}

Antes de tudo é preciso afirmar que a filosofia russa é propedêutica da reflexão religiosa sobre o ser e a existência em Paul Evdokimov. Em sua obra intitulada Le Christ dans la pensée russe, ele chega a abordar ou pelo menos mencionar alguns pensadores russos. Tal abordagem nos conduz a uma melhor compreensão de sua reflexão cristológica.

Paul Evdokimov percebe que o século XIX passa por um grande renascimento da reflexão filosófica, colocando os pensadores russos entre os grandes pensadores da cultura universal sob a dimensão escatológica do tempo histórico ${ }^{408}$. Tal renascimento é fruto de um pensamento vivo, relacionado diretamente com a realidade e a vida do povo russo, bem como com a sua relação com a cultura, com o destino da história coletiva e particular do homem e, como não poderia deixar de ser, consigo mesmo. O pensamento russo volta-se para si mesmo, para a sua própria realidade e interrogando-se sobre o que Deus pensou da Rússia ${ }^{409}$. Assim, percebe-se que no pensamento russo não há uma clara distinção entre teologia e filosofia religiosa.

Neste sentido da Rússia pensar a si mesma a partir de sua realidade e não a partir de elementos importados, Paul Evdokimov aborda alguns nomes que se debruçaram sobre esta tarefa. Para ele, enquanto Pedro Tchaadaev $(+1856)$ fala da dimensão escatológica do tempo histórico, Vladimir Soloviev $(+1900)$ fala da realização imanente da história, partindo do princípio de que a realidade da história está em função da síntese final, ou seja, o Reino de Deus ${ }^{410}$.

Para Evdokimov o ponto mais alto do pensamento de Soloviev é o teandrismo do Deus-Homem, ou seja, a fé em Deus e a fé no homem como a plenitude da verdade. Segundo nosso autor, Soloviev tem o mérito de preparar o renascimento da consciência russa em fins do século XIX e início do século XX. Filósofo de grande envergadura, ele propõe um conhecimento orgânico e integral à luz do teandrismo cristológico. Partindo da dimensão divina do homem e da

\footnotetext{
408 ld. L'Orthodoxie., p.38.

409 ld. Le Christ dans la pensée russe., p.62.

${ }^{410}$ Id. L'Orthodoxie., p.38.
} 
dimensão humana de Deus, Soloviev defende que esta relação tornou a história uma economia teândrica da salvação, isto é, um compêndio do conhecimento dos mistérios divinos que congrega o pensamento lógico ocidental e o conteúdo das contemplações orientais, o que constitui o cristianismo universal. A práxis de tudo isso é traduzida na missão social e ecumênica da Igreja que, para Evdokimov, Soloviev constrói como fruto de sua reflexão filosófica sobre o dogma de Calcedônia.

Em meados do século XIX surge na Rússia o movimento eslavófilo, que objetivava o desenvolvimento de uma filosofia cristã autenticamente russa, como uma reação de índole nacional e espiritual frente ao cosmopolitismo e racionalismo do século XVIII. Trata-se, por assim dizer, de uma reação a ocidentalização da intelectualidade. Os eslavófilos, orgulhosos da tradição eslava, opunham-se à influência da mentalidade positivista e materialista do ocidente latino. Neste sentido, tal movimento desejava engenhar uma identidade nacional do povo russo, blindando-a de influências estrangeiras. Para os eslavos, a associação de todas as faculdades do pensamento possibilita a harmonia do coração e da inteligência, levando a um conhecimento vivo. Destarte, o verdadeiro conhecimento está em vista do conhecimento de Deus e do dogma como fonte de vida ${ }^{411}$.

O movimento dos eslavófilos, segundo Evdokimov, tinha em Alexis Khomiakov $(+1860)$ o seu precursor, que percebe na experiência eclesial a fonte e a medida de toda a teologia e da unidade do povo. A lgreja é, para Khomiakov, o verdadeiro sujeito da liberdade, que tem a pessoa humana como membro do corpo de Cristo. Segue-se assim, que a liberdade é, na verdade, não um direito, mas sim um dever ${ }^{412}$. E tal percepção eclesial influenciará fortemente a reflexão cristológica de Paul Evdokimov.

Já Nicolas Fédorov (+1903), segundo Evdokimov, compreende o Evangelho como um projeto, em que a história é um campo de combate pela dignidade do ser humano ${ }^{413}$. Sendo assim, os cristãos, chamados a seguir e imitar Cristo, têm como ética do dever, uma ética da ressurreição, que por sua vez consiste em vivêla já e não somente na vida após a morte. ${ }^{414}$ Trata-se de uma escatologia ativa e dinâmica, consequência de uma cristologia assumida na vida. Daí decorre a constatação de que os pensadores russos se preocupam com o ser humano e o seu destino precisamente porque recorrem ao dogma cristológico para decifrarem

\footnotetext{
${ }^{411}$ KOUBETCH, V. Da criação à parusia., p.186.

412 EVDOKIMOV, P. Le Christ dans la pensée russe., p.65ss.

413 lbid., p.80ss.

414 ld. L'Orthodoxie., p.38.
} 
o mistério humano e divino inseridos no mundo. Por isso, Evdokimov em sua reflexão teológica fará uma espécie de colcha de retalhos daquilo que conhecemos como tratados, tais como Trindade, cristologia, antropologia, escatologia, pneumatologia, sacramentária, eclesiologia, etc, a partir destes pensadores.

Do filósofo Teodoro Boukharev (+1871), Paul Evdokimov colhe a compreensão de que a criação culmina com a encarnação, que coloca o homem em nova condição ontológica, isto é, na ordem da deificação. Para Boukharev, o sacramento da unção crismal é o sacramento do sacerdócio universal do laicato ${ }^{415}$. Tema que será bastante caro a Evdokimov.

Há ainda outros dois grandes autores russos que influenciaram decisivamente o pensamento de Evdokimov, aos quais ele dedicou duas de suas principais obras. São eles Nicolas Gogol (+1852) e Fiódor Dostoievsky (+1881). Gogol é considerado por Evdokimov um "louco por Cristo”, peregrino solitário, que percebe na história cotidiana a presença do mal e do anticristo. Nicolas Gogol trilha caminho para uma dimensão escatológica do pensamento russo num dinamismo apocalíptico. Sobre Gogol, Evdokimov escreveu a obra intitulada Gogol et Dostoievsky ou la Descente aux Enferns. Já a Fiódor Dostoievsky, Evdokimov dedica a sua própria tese de doutorado em filosofia que depois the renderá a obra Dostoievsky et le problème du mal. Para Evdokimov, Dostoievsky aborda uma antropologia cristológica, em que o destino do ser humano à luz da encarnação ocupa o centro de sua pesquisa, de modo que o ser humano existe para ser semelhança de Deus; e se Deus não existe, o ser humano também não existe $^{416}$. Ainda na obra Os Irmãos Karamázov, em que Dostoievsky apresenta a Lenda do Grande Inquisidor, o autor traz Cristo como o protótipo de homem livre e consciente. O ser humano é um ser aberto, porém inacabado, em constante processo de aperfeiçoamento. Dostoievsky aí partindo do dogma trinitário, declara o valor pessoal que cada ser humano possui ao ser criado do nada e plasmado do pó da terra à imagem e semelhança de Deus, ou seja, deiforme.

\subsection{4}

\section{A cristologia russa}

Se o Ocidente vive em um progressivo processo de secularização desde o século XVI com o advento do Modernismo de Descartes com o seu cogito ego

\footnotetext{
415 Id. Le Christ dans la pensée russe., p.86s.

416 lbid., p.94ss.
} 
sum, a Rússia também não escapará de um processo de secularização que se inicia a partir da crise do século XVII, em que os teólogos da escola de Kiev introduzem a teologia latina, que por sua vez tem que dividir espaço com uma tendência luterana dirigida por Théphane Prokopovitch. Com o Imperador Pedro Magno, inicia-se o absolutismo oridental e com ele o processo de secularização. Com efeito, a atuação da lgreja fica relegada às necessidades imediatas dos fiéis, contudo, estas são definidas pelo Imperador $^{417}$. A reação da teologia à tal conjuntura, é a imagem kenótica do Cristo humilhado, os loucos de Cristo. ${ }^{418}$ Outrossim, a reflexão cristológica russa será fortemente marcadapela ideia Deus Humanidade, ou seja, pelo amor descendente de Deus no Filho, pelo Espírito Santo.

O Metropolita Filarete de Moscou é lembrado por Evdokimov, quando em uma homilia de Sexta-feira Santa, declarou: "O Amor do Pai, que crucifica, o Amor do Filho, que é crucificado, o Amor do Espírito Santo, que triunfa pelo poder invisível da Cruz"419. Tal declaração quer expressar a forma como Deus amou o mundo, mistério indizível que remonta à imolação do Cordeiro. Vitor Nesmélov (+1920) compreende esta imolação como a morte do Crucificado da qual vem a salvação humana: "Deus morre para que o ser humano viva"420. Com efeito, para Nesmélov, a salvação é a conformidade do ser humano ao Amor do Cristo.

Uma nova e eterna aliança entre Deus e o homem é o objetivo da encarnação, segundo a visão da teologia russa. Da parte de Deus ela servirá para que o Pai encontre todos os seres humanos como seus filhos no seu Filho Unigênito. Da parte do homem ela servirá de exemplo vivo do Cris to, que desperta a sede humana de Deus, do Amor crucificado ${ }^{421}$.

Paul Evdokimov entende que para Nicolas Berdiaev (+1948) a história é fruto do seio da Divindade. Pois é no Filho que Berdiaev vê o amor ilimitado que tem em si a conjunção de dois destinos: o da história da vida divina e o da vida humana no mundo ${ }^{422}$. Neste sentido, apenas em Deus torna-se possível entender o tempo e a eternidade, o princípio e o fim $^{423}$.

O homem do humanismo ateu é pura e simplesmente inumano, pois não é o homem, é Deus que é humano. Em Cristo, Deus-Homem, há o nascimento de Deus

\footnotetext{
417 Id. L'Orthodoxie., p.34.

418 lbid., p.35.

${ }^{419} \mathrm{ld}$. Le Christ dans la pensée russe., p.59.

420 Ibid., p.140.

421 Ibid., p.128.

422 BERDIAEV, N. El sentido de la historia., p.53.

${ }^{423}$ EVDOKIMOV, P. Le Christ dans la pensée russe., p.167.
} 
no homem e o nascimento do homem em Deus. Deus se humaniza para que o homem seja divinizado ${ }^{424}$.

Portanto, a cristologia russa é descendente, é a do Cristo sofredor e peregrino. Jesus é a encarnação de Deus. E esta consiste, antes de tudo, na recriação do homem. Trata-se de uma cristologia eminentemente encarnada, mas ao mesmo tempo contemplativa, marcada pela esperança e imersa no mistério da Cruz, Paixão e Ressurreição do Senhor.

O Filho de Deus só pode salvar o mundo entrando nele a fim de nele introduzir, por sua morte e ressurreição, condições ontológicas completamente novas para assim oferecer ao homem sua deificação. A Encarnação conclui a Criação. Ela é seu oitavo dia, que torna o homem livre em seu amor a Deus ${ }^{425}$.

Segundo Evdokimov, a Filosofia da História super badalada no século XX, deve ceder espaço para a Teologia da História, em que o Deus da história tornase Deus na história. Pois Cristo entra na história e muda completamente a dimensão da história, nela dando testemunho do louco amor de Deus pelo mundo, na expectativa do fiat do ser humano ao seu fiat $t^{426}$.

\subsection{5 \\ A cristologia em Paul Evdokimov}

Paul Evdokimov procura retomar o estilo teológico dos Padres da lgreja, apropriando-se das intuições filosóficas de sua época, delas fazendo uma verdadeira síntese para a construção de sua própria reflexão, em que seu pensamento cristológico seja uma cristologia do ser humano e de sua deificação em Cristo, pelo Espírito Santo ${ }^{427}$. De modo que Jesus Cristo seja o lugar da humanização de Deus e da deificação do homem. Neste sentido, segundo Evdokimov, o pensamento teológico deve ter como ponto de partida o Deus Homem.

Nem o Deus de uma teologia triunfalista e ultrapassada, nem um homem de um ateísmo caduco e sem fôlego, mas uma teologia do Deus-Homem, do Cristo cósmico devolvendo à natureza e ao homem seu estatuto ontológico do Oitavo Dia pode falar ao homem de hoje, responder à sua sede ${ }^{428}$.

É exatamente este o objetivo de Evdokimov, que sua cristologia seja uma cristologia para o cristão de hoje, de maneira que ele se engaje na história de

\footnotetext{
424 Ibid., p.168.

425 lbid., p. 165.

426 Id. A mulher e a salvação do mundo., p.40.

427 Id. L'Orthodoxie., p.2.

${ }^{428}$ Id. Le Christ dans la pensée russe., p.216.
} 
forma livre e madura, respondendo às exigências do tempo e às inspirações do Espírito Santo. Pois a encarnação torna Cristo em centro de toda história. Depois dele nada se acrescenta à história, de modo que esta deve ser lida à luz da cristologia.

Tudo o que se passou antes, não foi senão prefiguração, e tudo o que se processa depois é a extensão da encarnação, o tempo da Igreja. E a vida da Igreja apresentase como nova dimensão de vida, a faculdade da nova qualificação da história, porque aberta para o definitivo ${ }^{429}$.

A possibilidade de união do Criador à criatura, deificando-a, é a encarnação; quando, então Deus e homem se encontram e se reconhecem. Assim, a deificação do homem pressupõe a humanização de Deus.

O Eros divino, diz Macário, faz descer Deus à terra, força-o a deixar o ápice do silêncio. Os desejos divino e humano culminam no Cristo histórico, em quem Deus e o homem se olham como num espelho e se reconhecem porque o amor de Deus e o amor dos homens são dois aspectos de um único amor total ${ }^{430}$.

\subsection{6}

\section{O Verbo encarnado como lugar de encontro do divino com o humano}

Para Evdokimov, o Verbo Encarnado é o lugar da comunhão do divino com o humano. É nele que a natureza humana é restaurada, isto é, o ser humano criado do nada e plasmado do pó da terra, tem a sua imagem e semelhança com Deus restauradas ${ }^{431}$. E é nesta restauração que a vocação do ser humano de comunhão com Deus é concretizada. "Em Cristo o divino une-se ao ser humano, e o ponto de comunhão é a pessoa divina do Verbo"432. Com efeito, Cristo e o ser humano são teândricos, ou seja, a divindade revela-se na humanidade em um equilíbrio perfeito entre o agir divino e o agir humano, mantendo-se a condição de cada um, embora haja uma verdadeira comunhão, ou participação de um na vida do outro.

É precisamente isso que uma reflexão mais aprofundada e atualizada da definição cristológica do Concilio de Calcedônia nos leva a compreender melhor: em Jesus Cristo, não somente há duas naturezas distintas em uma única pessoa, como também temos aí a base necessária para a percepção de que é na deificação que somos unidos com Deus em uma comunhão perfeita, ou seja, sem confusão. Assim, é Jesus o lugar, ou melhor, a pessoa onde acontece o teandrismo, haja vista que é na encarnação que o Verbo Divino assumea natureza

\footnotetext{
429 Id. A mulher e a salvação do mundo., p.140.

430 Id. L'Orthodoxie., p.79.

431 Ibid., p.19.

432 Id. O Sacramento do Amor., p.59.
} 
humana e torna-se Deus-Homem, ou Deus conosco. Somente a partir daí podemos falar em humanização de Deus e deificação do homem, pois o mistério da encarnação implica este último grau de comunhão.

Ora, a humanização de Deus tem a ver com a salvação do ser humano. Pois esta humanização em Jesus pelo mistério da encarnação, possibilita uma participação efetiva na comunhão da vida divina, ou no próprio mistério da vida intra-trinitária. É a realização da vocação humana e do sentido mais ínfimo de sua existência, é a criação levada à plenitude. Esta é a reflexão dos Padres, tão cara a Evdokimov e por ele seguida, a saber: a deificação do ser humano consiste na sua cristificação.

O plano salvífico original de Deus traz consigo o mistério da encarnação. Através deste mistério, Deus quer configurar o ser humano ao seu Filho, de modo que o ser humano alcance em Cristo a filiação adotiva e a plenitude da vida. Em seu amor pelo homem Deus revela sua filantropia expressa em suas energias, das quais o cristão participa.

O cristianismo traz em seu bojo um paradoxo que encontra seu equilíbrio na transcendência radical de Deus em si, Deus absconditus em sua essência, e na imanência do Deus econômico, Deus revelatus em suas energias, na graça da encarnação, na qual o Deus Filantropo transcende sua própria transcendência ${ }^{433}$.

Só é possível ir a Deus a partir dele mesmo, ou seja, para ir a Deus é preciso estar nele. Este é o sentido de transcendência divina ${ }^{434}$. Contudo, este Deus transcendente não é um Deus alheio à realidade humana, ou um Deus estático, que não se relaciona. É um Deus pessoal e que age. E as energias divinas recebidas pelo homem, são o que de fato o conduzem a este Deus transcendente e pessoal que se revela ao mundo visível em Jesus Cristo, O Filho Unigênito. Jesus como sacramento do Pai, é a epifania da própria divindade, o lugar de encontro do ser humano com Deus. Segui-lo é sentir-se com Ele, é conformar-se com Ele, para que sejamos verdadeiramente à imagem e semelhança de Deus. Mas, é o Espírito Santo, dom de Deus, que reproduz no cristão a imagem do Filho, realizando em nós o mesmo que fez em Jesus. É o dom do Espírito que nos possibilita o seguimento de Jesus e a realização da nossa humanidade em plenitude a partir da deificação.

Para Evdokimov, a encarnação é fruto da vontade de Deus de revelar-se, de comunicar-se, de "teofanar-se", para que o homem, por sua vez, participe da

\footnotetext{
433 Id. L'Orthodoxie., p.14.

434 lbid., p.50.
} 
vida divina por meio da sua graça ${ }^{435}$. Neste sentido, em suma, o objetivo da encarnação é a deificação do homem, que, por sua vez, consiste na sua plenificação. Pois ele só é verdadeiramente homem em Cristo, Filho de Deus que se fez Filho do Homem, que recapitula em si toda história da salvação e que, no âmbito do mistério da encarnação, constitui o verdadeiro Arquétipo do homem. Daí segue-se, que em Evdokimov só podemos perceber o mistério da criação a partir do mistério da encarnação. Pois tudo o que há, foi feito por Cristo, em Cristo e nele se sustenta.

No âmbito da Trindade, na linha dos Padres da Igreja, Evdokimov propõe uma teologia em que o ser humano está associado à revelação trinitária do ser pessoa como ser de relação. No sentido de que "ao buscar Deus, é o ser humano que é encontrado por Deus, perseguindo sua verdade, é ela que capta o ser humano e o transpõe ao seu nível eônico do Reino" ${ }^{436}$. E esta deve ser exatamente a postura de todo teólogo: não especular, mas se deixar transformar por aquilo que ele procura. ${ }^{437}$ Para o nosso autor, o Oriente insiste no tema da nova criatura em que somos transformados através de uma nova existência, segundo o modo divino. Assim, o ser humano só pode ser percebido a partir do dogma trinitário. Aí, conforme aprendemos, cada uma das pessoas divinas vive a circumincessão de amor das três.

Cada Uma está voltada para a Outra, é o co-esse: a Pessoa é para a comunhão trino-uma. Estritamente falando, a pessoa só existe em Deus. O homem, imagem, tem a nostalgia de tornar-se pessoa e só se realiza na participação em seu Arquétipo divino. (...) A deiformidade do homem no momento de sua criação "à imagem de Deus", culmina na estrutura teândrica, divino-humana da humanidade do Cristo 438 .

"Foi em Cristo que Deus Pai nos escolheu para sermos seus filhos adotivos, santos e irrepreensíveis diante de seu amor"439. Com efeito, como acima exposto, Ele é o Arquétipo a partir do qual o ser humano é criado e recriado. Cristoé o novo Adão que recapitula e integra em si toda a criação. É neste sentido que Ele é o Arquétipo daquilo que somos chamados a ser, a saber: imagem de Deus.

Quando Evdokimov afirma que Cristo é o Arquétipo, ele quer se referir ao conteúdo ontológico de "imagem" (a imagem/ à imagem). Haja vista que na encarnação, Cristo reúne em si a imagem de Deus e a imagem do homem. Logo, o princípio ontológico do ser humano está no seu ser em Cristo e não no seu ser

\footnotetext{
435 Id. La connaissance de Dieu selon la tradition orientale, l'enseignement patristique liturgique et iconographique., p.06; Id. A mulher e a salvação do mundo., p.41.

436 Id. L'Orthodoxie., p.14.

437 Id. La nouveauté de l'Esprit: études de spiritualité., p.82.

438 Id. Une vision orthodoxe de la théologie morale., p.81.

439 Ef 1,3-5.
} 
fisiológico e psíquico. Cristo é o Arquétipo do ser humano precisamente porque traz consigo a sua verdade ontológica, de modo que a mesma não se encontra no homem, mas em Cristo, Deus feito homem. Neste ponto, Paul Evdokimov lança mão da reflexão teológica de Máxime Tarêev (+1934), que afirma uma dupla kênose em Cristo, em que Ele se despoja de sua condição divina e enfrenta a tentação religiosa da igualdade a Deus, por viver totalmente referido a Deus, na obediência filial.

O Cristo reconcilia em si não Deus com o homem, mas o homem com Deus, pois Deus não é mais o "totalmente Outro", ele se humanizou, tornou-se em Cristo o homem total. Satanás sugere ao Cristo que encurte os termos da história pela magia do poder divino. É o Homem em Cristo que rejeita esta tentação e sua resposta humana coincide com a resposta divina. É a unidade da consciência teândrica pela fé, que o Deus-Homem oferece a todos pela sua vitória. Todo fiel deve reproduzir a mesma vitória em si mesmo e encontrar assim obediência filial ao Pai ${ }^{440}$.

\title{
6.1.7 Indivíduo e Pessoa
}

Paul Evdokimov distingue os termos prósopon de hypóstasis: prósopon refere-se ao âmbito psicológico do ser humano voltado para sua interioridade e para a consciência de si mesmo; já hypóstasis refere-se ao âmbito espiritual do ser humano aberto e transcendente a seu próprio mundo em direção a Deus. "É a posição teândrica da pessoa humana condicionada por sua deiformidade inicial e acabada em Cristo. A hipóstasis é o ultrapassamento de si mesmo em direção a Deus" 441 . O homem ultrapassando a si mesmo descobre que o núcleo mais íntimo de sua identidade não está nele mesmo, mas em Cristo. Utilizando-se elementos da psicologia, em artigo sobre o mistério da pessoa, o teólogo ortodoxo afirma:

\begin{abstract}
O indivíduo está centrado sobre sua alma e sobre o seu eu biológico e psíquico. A pessoa está centrada sobre o espírito e sobre o eu infinitamente mais profundo que o eu empírico. Esse eu, segundo Jung, é misterioso e escapa a toda definição. Ele é inacessível a toda psicologia que não ultrapassa a psiqué, que não desemboca sobre a pneumatologia. ${ }^{442}$
\end{abstract}

Todavia, também declara: "no estado natural, o prósopon confunde-se com o indivíduo, ele é apenas mera potencialidade da pessoa e postula sua passagem do prósopon à hypóstasis"443. Assim, continua:

Todo ser humano possui um rudimento de pessoa, um centro imanente de integração e de consciência de si, é o prósopon como dado universal de uma substância razoável. (...) A evolução do prósopon em hypóstasis é a passagem de

\footnotetext{
${ }^{440}$ EVDOKIMOV, P. Le Christ dans la pensée russe., p.133.

${ }^{441} \mathrm{ld}$. Une vision orthodoxe de la théologie morale., p.81.

442 Id. Mystère de la personne humaine., pp.272-289.

${ }^{443} \mathrm{ld}$. Une vision orthodoxe de la théologie morale, p.82.
} 
ser natural a ser crístico, verbificado, deificado: "Já não sou eu que vivo, mas é o Cristo que vive em mim" 444 .

Aí Evdokimov faz uma distinção entre indivíduo e pessoa. Para ele, indivíduo designa o indivisível, um átomo, que é elaborado pelo processobiológico, ou seja, nasce e morre, está ligado à categoria natural biológica. Já pessoa, está centrada sobre o eu espiritual, que, por sua vez, transcende o eu empírico e biológico do indivíduo. ${ }^{445}$ Para Evdokimov, o indivíduo tem o seu fim em si mesmo e a si mesmo basta, ao passo que pessoa possui um destino que ultrapassa o indivíduo. É como diz Jesus no Evangelho: "Pois aquele que quiser salvar a sua vida, vai perdê-la, mas o que perder a sua vida por causa de mim, vai encontra-la"446.

Em suma, pessoa só existe em Deus. Ele é a própria causa de seu modo de ser "à imagem" 447 . Enquanto que a natureza não concede existência única. Esta oferece ao homem o que é no todo, não o que é no particular. A pessoa protege a unidade e a particularidade absolutas. Ser pessoa ultrapassa o indivíduo, e daí garante aquilo que se pode denominar de individualidade autêntica, que, por sua vez, nada tem a ver com individualismo.

\subsection{8}

\section{A deificação do ser humano em Paul Evdokimov}

Ao contrário do que muitas vezes se vê na percepção do Ocidente, em que a experiência de vida cristã deve ser traduzida em uma práxis, Paul Evdokimov entende a experiência da vida cristã em um nível mais existencial da fé, ou como uma experiência mística, consciente da dinamização pneumatológico-cristológica do amor divino. Nesta perspectiva, o homem "torna-se segundo a graça o que Deus é segundo a natureza" ${ }^{448}$. Para Evdokimov, a dinâmica de deificação consiste na pneumatização do ser humano pelas energias divinas.

A "théosis", estado deificado do ser humano, sua penetração pelas energias divinas, exprime o ideal religioso do Oriente. A antropologia oriental é a ontologia da deificação, iluminação progressiva do ser cósmico e do homem. ${ }^{449}$

O sacerdote ortodoxo ainda adverte que a antropologia ortodoxa não é moral, e sim ontológica. Ela é a ontologia da deificação. ${ }^{450}$ Ela não está em vista

\footnotetext{
444 lbid., p.81.

445 lbid., p.80.

446 Mt 16,25.

447 EVDOKIMOV, P. A mulher e a salvação do mundo., p.52.

448 Id. La connaissance de Dieu selon la tradition orientale, l'enseignement patristique liturgique et iconographique., p.06; Id. A mulher e a salvação do mundo., p.97.

449 lbid., p.130; Id. O silêncio amoroso de Deus., p.46.

450 ld. A mulher e a salvação do mundo., p.86.
} 
deste mundo, mas do Reino de Deus, da transformação interior do mundo em Reino, da sua iluminação progressiva pelas energias de Deus. ${ }^{451}$ Assim, para Evdokimov, a vida do cristão comporta "crer, unir-se, conhecer e metamorfosearse em imagem e semelhança de Deus" ${ }^{452}$. Este processo de deificação, que ocorre na própria dinâmica da vida místico-cristã, é encontro pessoal e interior com Cristo pelo Espírito; mas é antes de tudo iniciativa gratuita de Deus.

A economia do Filho e a economia do Espírito convergem em direção ao Pai, fonte da unidade trinitária e da vida espiritual dos homens. (...) A alma, tornada pela graça pneumatófora, é aí cristificada. (...) A epíclise da união mística é fundamental, é pelo fato de o homem ter-se tornado pneumatóforo que ele torna-se cristóforo ${ }^{453}$.

Para Evdokimov, é o Espírito Santo quem nos leva ao Pai, mas por meio do Cristo, tornando-nos membros do mesmo Corpo 454 . "À imagem do pão e do vinho, o ser humano, pela ação do Espírito, torna-se uma parcela da natureza deificada do Cristo" 455 . Desta maneira, o homem é realmente cristificado, ou seja, o "barro recebe a dignidade régia... transforma-se em substância de Rei"456.

Como já percebemos até aqui, Evdokimov dá um realce especial à imago Dei em sua reflexão. Para ele, ela é o elemento constitutivo do ser humano, que, por sua vez, é o fundamento de toda antropologia. A imago Dei ao nos reportar ao estado anterior à queda, em que os primeiros pais gozavam dos dons preternaturais, nos recorda que o pecado atingiu exatamente a imago Dei.

\begin{abstract}
A imago é esse terceiro termo de afinidade, de conformidade, de correspondência que faz ver o homem em Deus, "a face de Deus exprimida em traços humanos" e o divino do homem, o homem deificado. Com isto, chega-se a ponto de poder reverter o enunciado habitual, segundo o qual a encarnação é condicionada pela queda, e dizer: inicialmente, "no começo", no princípio mesmo, a criação do homem "à imagem" visava a encarnação-deificação, é então "de inspiração" (in-spirare) essencialmente teândrica. ${ }^{457}$
\end{abstract}

Neste sentido, para Evdokimov, a dinâmica de deificação tem como sentido primeiro esta ideia bíblica de que o homem é criado à imagem e semelhança de Deus. A partir daí, seguindo a reflexão dos Padres da lgreja, ele articula tal ideia com a noção de filiação em São Paulo na interpretação joanina: "o filho é aquele em quem Deus fez sua morada, é a inabitação do divino"458.

\footnotetext{
451 lbid., p.94.

452 EVDOKIMOV, P. La connaissance de Dieu selon la tradition orientale, l'enseignement patristique liturgique et iconographique., p.129.

453 Id. L'Orthodoxie., p.111ss.

454 Ef 3,6.

${ }^{455}$ Id. O silêncio amoroso de Deus., p.47.

456 lbid.

457 ld. L'Orthodoxie., p.79.

458 lbid., p.94.
} 


\section{1 .9 \\ A deiformidade humana}

Se na criação o homem é criado do nada e plasmado do pó da terra à imagem e semelhança de Deus (Gn 1,26), isto é, deiforme; na encarnação Deus revela-se homoforme, ou seja, assume integralmente para si a natureza humana. Assim, nas Sagradas Escrituras, o tema da imago Dei faz parte da própria constituição do ser humano, bem como de sua relação com o Criador. Neste sentido, o referido tema é a base de toda a antropologia bíblica. Ser à imageme semelhança de Deus comporta uma alta dignidade, mas também uma grande responsabilidade. Pois cabe ao ser humano exercer poder sobre toda a criação (Gn 1,26-28). ${ }^{459}$ Ser imagem e semelhança de Deus é governar o mundo com a inteligência do Criador, inteligência no sentido mais profundo da palavra. Aí consiste o essencial da identidade e da dignidade do ser humano.

Nas cartas paulinas e no evangelho de São João, o tema da iamgo Dei é revestido de sentido cristológico, encontrando aí o seu significado mais profundo. Para São Paulo "Cristo é a imagem do Deus invisível, porque nele foram criadas todas as coisas" ( $\mathrm{Cl}$ 1,15-16). Com efeito, o homem foi criado à imagem e semelhança de Deus, exatamente porque foi criado por Cristo, em Cristo e para Cristo, Palavra Eterna do Pai, o Primogênito de toda criatura. Para o Apóstolo, o homem é vocacionado a realizar-se plenamente no estado do Homem Perfeito, a medida da estatura da plenitude de Cristo $(E f 4,13)$. Já para São João, a unidade entre o Filho Unigênito e o Pai, Deus invisível por Ele revelado (Jo 1,18), expressa uma relação tal que supera a função de mediador. Para o Discípulo Amado, Cristo é reflexo da glória do Pai (Jo 17,5): "Quem mevê, vê o Pai" (Jo 14,9). Estas noções de filiação presentes em São Paulo e em São João, muito bem articuladas pelos Padres, são inspiração para o pensamento de Paul Evdokimov sobre a dinâmica de deificação do homem. Em Cristo "os filhos no Filho são de fato os filhos do Pai, semelhantes ao Filho" ${ }^{460}$.

Santo Irineu, por exemplo, aborda a relação da imago Dei em São Paulo com o mesmo tema no livro dos Gêneses. Para ele, Cristo é a imagem de Deus e o homem é a imagem do Cristo $(\mathrm{Cl} 1,15)$. Neste sentido, o homem feito à imagem

\footnotetext{
459 Para o teólogo ortodoxo grego Panayotis Nellas, os Padres da Igreja compreendem o homem como senhor do universo. Seu senhorio é uma forma de êxtase de sua identidade real. De modo que, numa visão de fé, nenhum científico ou tecnológico é surpreendente. Pois descobrindo os segredos do mundo e o organizando, o homem cumpre com a sua vocação, se por esta organização dos segredos do mundo, ele move-se em direção à humanização. In Revista Fuentes, 1993. Argentina. Teólogos Ortodoxos Contemporâneos.

${ }^{460}$ EVDOKIMOV, P. La connaissance de Dieu selon la tradition orientale, l'enseignement patristique liturgique et iconographique., p.36.
} 
de Cristo, é a imagem da Imagem ${ }^{461}$. Já Clemente de Alexandria e Orígenes compreendem que a alma foi recebida no momento da criação como germe de divinização. Assim, a divinização é o fim último da imago $D e{ }^{462}$.

Com frequência, os Padres compreendem que a imagem se perdeu por causa do pecado. Contudo, quando se dedicam mais exatamente a este assunto, Orígenes, Atanásio, Basílio e outros, entendem que a imagem é indestrutível, mesmo quando o pecado a esconde; mesmo aí ela continua indelével na orientação para o sobrenatural que constitui o seu dinamismo. Contrariamente, Cirilo e Agostinho, que percebem uma dupla imagem, ou um duplo plano na imagem, defendem que a segunda imagem se perdeu por conta do pecado, enquanto a primeira subsiste. Entretanto, em geral os Padres entendem que a restauração desta imagem perdida, ou encoberta, é obra de Cristo em sua encarnação e redenção, que por sua vez torna o homem filho de Deus ${ }^{463}$.

Se na teologia patrística o tema da imagem e semelhança possui uma profundidade incomensurável em toda a diversidade entre os Padres, na contemporaneidade, o referido tema também provoca reflexões bastante relevantes. É o caso do teólogo luterano Wolfhart Pannenberg, cujo esboço cristológico já foi aqui explanado. Ele defende que a imago Dei tem o objetivo de expressar o caráter incompleto da humanidade do ser humano. Para ele, o homem é um ser dotado de abertura ao mundo. Tal abertura é o que constitui o homem como imagem. Esta imagem, por sua vez, é simultaneamente o fim e o início da realização humana. Assim, para Pannenberg, a realização da imagem e semelhança de Deus no ser humano é, ao mesmo tempo, processo como resposta ao desígnio de Deus e dom oferecido por Deus ao ser humano ${ }^{464}$.

Já Paul Evdokimov, segue uma linha mais escatológica. Ele afirma que apesar da diversidade com que os Padres abordam o tema da imago Dei, todos eles são unânimes em defender que a imagem é o princípio constitutivo do homem e seu destino primeiro antes da queda, não mera ideia reguladora ou instrumental. ${ }^{465} \mathrm{E}$ é justamente esta destinação primeira que o define. Pois a sua condição de ser criado à imagem e semelhança de Deus é o que o encaminha ao destino para o qual ele foi criado: a deificação.

"Ser à imagem" tem em si o carismatismo inicial, a imagem comporta a presença indestrutível da graça inerente à natureza humana, implicada no ato mesmo da

\footnotetext{
461 Irineu. Adversus Hereses.

462 DI BERARDINO, A. (Org.). Dicionário Patrístico e de Antiguidades Cristãs., p.707.

463 lbid., p.706.

464 PANNENBERG, W. Apertura al mundo e imagen de Dios., pp.53-98.

${ }^{465}$ EVDOKIMOV, P. L'Orthodoxie., p.78.
} 
criação. "O sopro da divindade invisível" insuflado na alma, a predispõe para a participação no Ser divino. (...) a imagem predestina o homem à theosis ${ }^{466}$.

Para Evdokmov, encarnação e théosis (deificação) são complementares. Ambas realidades nos evidenciam que o sentido do ser em seu carismatismo inicial, ou seja, na sua origem, corresponde ao desejo de Deus de se encontrar com o homem ${ }^{467}$. Deus se encarna no seu ícone vivo: o homem é a face humana de Deus ${ }^{468}$. A natureza humana traz consigo as marcas de Deus. O homem, criado à imagem de Deus está marcado pela imago Dei, cujo objetivo último é a comunhão com Deus.

O fato de ser criado segundo a graça divina abre-se sobre a tarefa a cumprir: tornarse efetivamente santo, perfeito, deus segundo a graça, participando das condições da vida divina: imortal e íntegro, "casto". A imagem, fundamento objetivo, pela estrutura dinâmica, chama à semelhança subjetiva, pessoal 469 .

A teologia ortodoxa, tradicionalmente dá bastante destaque ao tema da imago Dei. Pois os teólogos ortodoxos em geral percebem aí uma teologia viva e acessível a todos. Exatamente por ser ícone de Deus, o ser humano pode encontrá-lo voltando-se para si mesmo. Algo semelhante com o tema do capax Dei presente no pensamento de Santo Agostinho.

Ora, mas se Deus está em mim, Ele também está no outro, que também foi criado à imagem de Deus. É neste sentido, que Paul Evdokimov afirma que quando vemos o nosso irmão, vemos a Deus. De modo que o homem é o melhor ícone de Deus ${ }^{470}$. Isso, a despeito do drama da queda experimentado pelo ser humano a partir da desobediência dos primeiros pais. Com efeito, o pecado original não define o sentido último da existência humana, que permanece o mesmo do ato criativo de Deus, a saber: a deificação, que em última análise consiste na comunhão da vida divina. Sendo assim, segundo Evdokimov, "nenhum mal poderá apagar o mistério inicial no ser humano, porque nada existe que possa aniquilar nele o cunho indelével de Deus"471. A originalidade do ser humano é anterior à queda, e desde que ele foi configurado a Cristo, é esta sua verdade original que define o seu destino. De maneira que o pecado original em nada modifica o projeto original da encarnação ${ }^{472}$.

\footnotetext{
466 lbid., p.80.

${ }^{467}$ Id. Une vision orthodoxe de la théologie morale., p.73.

468 Id. L'Orthodoxie., p.79.

469 lbid., p.84.

470 lbid., p.218.

${ }^{471} \mathrm{Id}$. A mulher e a salvação do mundo., p.84.

472 lbid., p.136.
} 
A Encarnação de Deus aparece como uma resposta à sua própria premissa: a deiformidade de sua criatura. A queda do homem mostra a amplitude de sua liberdade que determina o seu destino. Satanás não mentiu, dizendo: sereis como deuses; o homem tem que criar algo que nunca existiu antes, introduzindo o mal em sua natureza inocente. Mas, a salvação do homem determina a forma da encarnação como o amor crucificado. O sangue divino foi derramado para salvaguardar a liberdade sob o influxo da graça, pois Deus, conforme o ensinamento dos Padres, não pode forçar ninguém a amá-10473.

Mas o drama da queda, para Evdokimov, também reduz a imagem ao "silêncio ontológico". Ela não é perdida, mas permanece inoperante. Por isso, precisa ser restabelecida. Assim, Cristo retoma o que foi desviado e interrompido pela queda ${ }^{474}$. Mas a queda, por sua vez coloca o homem em um estado patológico.

A patologia postula e apela ao ato terapêutico capaz de descer até a raiz da perversão e de operar a cura da natureza pela reconstituição de sua estrutura adâmica. A catarse ética, purificação das paixões e dos desejos, culmina na catarse ontológica: a metanóia, mudança completa de toda economia do ser humano. Tratase, portanto, do restabelecimento da forma primeira, da restauração arquetípica da imago $\mathrm{Dei}^{475}$.

Em suma, Paul Evdokimov, atento à teologia dos Padres, quer nos advertir a respeito de alguns aspectos:

1- Depois da encarnação a graça atualiza a deiformidade virtual ${ }^{476}$;

2- O germe "criado à imagem" aponta para o "existir à imagem" 477;

3- A deificação do ser humano está em função da humanização de Deus ${ }^{478}$;

4- O ser humano é a face humana de Deus ${ }^{479}$.

\section{2}

\section{Paul Gavrilyuk}

Dos teólogos cuja cristologia temos visitado, sem dúvida alguma Paul Gavrrilyuk é o mais jovem e por isso mesmo com uma abordagem mais contemporânea no que diz respeito ao mistério da encarnação. Nascido na Ucrânia e radicado nos EUA, Paul Gavrilyuk desenvolveu seus primeiros estudos teológicos em Moscou, sendo um dos primeiros teólogos da antiga União Soviética a ir aos Estados Unidos para prosseguir com seus estudos. Teólogo ortodoxo e historiador especialista em patrística grega e pensamento religioso

\footnotetext{
473 Id. L'uomo icona di Cristo., p.144.

474 Id. L'Orthodoxie., p.83.

475 lbid., p.78.

476 Id. La connaissance de Dieu selon la tradition orientale, l'enseignement patristique liturgique et iconographique., p.36.

477 Id. A mulher e a salvação do mundo., p.74.

478 Id. O silêncio amoroso de Deus., p.103.

479 lbid., p.103.
} 
russo moderno, Gavrilyuk tem construído reconhecimento internacional pela autoria de diversas obras e ministrando palestras e cursos em vários países, além de manter-se como professor de história da teologia na Universidade de São Tomás no estado de Minnesota nos EUA.

Paul Gavrilyuk defende que foi na controvérsia nestoriana, que a questão sobre a participação de Deus no sofrimento de Cristo encontrará sua maior relevância. Tal questão prepara o Concílio de Calcedônia, de modo que só se pode compreender a cristologia deste concílio a partir da compreensão de suas profundas raízes, ainda não devidamente exploradas. Para Gavrilyuk, as questões teológicas que constituem o centro da controvérsia nestoriana são tão sutis que sua interpretação tem se tornado em um tema bastante controvertido entre os historiadores da doutrina ${ }^{480}$. Sua conclusão central resulta na certeza de que é equivocado o pensamento segundo o qual a teologia patrística teria uma noção essencialmente impassibilista de Deus, alterada apenas por poucas vozes que defendiam o sofrimento divino. Para ele, ao contrário, a patrística acredita que Deus, conservando sua plena divindade aceitou livremente todas as consequências que derivam da encarnação, incluindo o sofrimento e a morte na cruz. Com efeito, Deus escolheu esta maneira para salvar o gênero humano, movido por sua infinita compaixão e seu infinito amor pelo gênero humano. E este é um ponto irrefutável da doutrina cristã, assim como do pensamento de Cirilo de Alexandria.

Apesar do Concílio de Calcedônia não ter tratado propriamente da passibilidade ou impassibilidade divina, este é o tema que constitui o pano de fundo em que se celebra o referido concílio. Ademais, é importante salientar que em sua análise, Gavrilyuk quer confrontar a corrente teopasquita ${ }^{481}$ contemporânea, que se utiliza de uma perspectiva metodológica demasiadamente restritiva, pecando a partir dos conceitos, assim como o impassibilismo atribuído equivocadamente aos Padres. Além da teoria segundo a qual Deus pode sofrer sem tomar forma humana, de modo que sua transcendência e encarnação perdem sentido. Ora, se a questão da passibilidade ou impassibilidade é uma questão ainda não totalmente resolvida, ou mal resolvida, é mister ouvirmos o que dizem

\footnotetext{
480 GAVRILYUK, P. El sufrimiento de Dios impassible., p.172.

481 O teopasquismo tradicional atribui ao próprio Verbo o sofrimento e a morte. A questão torna-se fundam ental para a compreensão do cis ma nestoriano e das discussões do Concílio de Calcedônia. Após o referido concílo, a controvérsia se centrava principalmente em duas fórmulas: qui crucifixus est pro nobis, acrescida ao Trisagium, e a outra unus de Trinitate passus est; na verdade tratava-se de um aspecto da doutrina da communicatio idiomatum, entendida de modo diferente tanto por alexandrinos, quanto por antioquenos e latinos, mas que no fim foi aceita por todos na significação alexandrina, sancionada pelo Concílio de Éfeso. Cf. DI BERARDINO, A. (Org.). Dicionário Patrístico e de Antiguidades Cristãs..
} 
autores contemporâneos sobre a questão teológica que foi o pano de fundo para o Concilio de Calcedônia. Pois uma vez percebida suas mais profundas raízes, podemos compreendê-lo melhor a fim de torná-lo mais acessível em nosso tempo. É o caso de Paul Gavrilyuk, que sugere que a passibilidade e impassibilidade são conceitos correlatos e ambos devem ter lugar cativo em qualquer discussão sobre intervenção divina ${ }^{482}$.

\subsection{1}

\section{As três vias cegas}

Paul Gavrilyuk aponta três vias cegas que dificultam a investigação das questões teológicas que protagonizam a controvérsia nestoriana, tornando-as bastante controvertidas entre os historiadores da teologia. A primeira via cega é aquela que tenta reduzir o debate a meros interesses políticos, considerando os temas teológicos como uma pilha de sofismas para ocultar a luta política entre as sedes arquiepiscopais de Alexandria e Antioquia. Segundo esta visão Cirilo seria como um faraó egípcio tirano, astuto no assassinato de Hipátia ${ }^{483}$, e inescrupuloso no suborno da corte de Teodósio, este, desonesto no trato dos assuntos da lgreja. Porém, Gavrilyuk assinala que estudos recentes ${ }^{484}$ revelam que este retrato histórico de Cirilo é, com efeito, uma distorção das provas. Entretanto, para além destas interpretações falseadas do caráter de Cirilo, este, conforme defende Gavrilyuk, deve ser visto como uma figura ambígua de amor ao poder e de sincero desejo em defender o ensinamento da lgreja daquilo que considerava distorções perigosas. Já Nestório, por outro lado, foi também um homem tão ambicioso quanto virtuoso; ou seja, nesta controvérsia ninguém é somente anjo ou demônio.

A segunda via cega que dificulta a interpretação é aquela que procura encarar o debate entre Cirilo e Nestório como símbolo das disputas entre as escolas teológicas de Alexandria e de Antioquia, mas uma via de cunho filosófico e não político como a primeira. De acordo com esta visão, a escola de Alexandria era marcadapelo predomínio do ensino do platonismo e a interpretação alegórica, além de enfatizar a divindade de Cristo em prejuízo de sua humanidade. Já a

\footnotetext{
482 lbid., pp.35-36.

483 Hipátia foi uma mulher neoplatonista grega, que pertencia à tradição matemática da Academia de Atenas e era da escola intelectual de Plotino. De acordo com o filosofo pagão Damáscio, Hipátia teria sido assassinada por uma multidão de cristãos, acusada de exacerbar um conflito entre 0 prefeito Orestes e o bispo Cirilo, duas figuras, portanto, de grande proeminência em Alexandria. Para Damáscio, que escreve quase um século depois e cujos escritos são de índole anticristã, Cirilo teria incitado o povo à agressão de Hipátia até a morte para atingir Oretes, sobrequem ela exercia grande influência política.

${ }^{484}$ MCGUCKIN, J. Cyril of Alexandria., pp.227-229.
} 
escola de Antioquia prezava pela filosofia de Aristóteles e se comprometia a preservar o sentido literal da Escritura; e por isso lançava luz sobre o tema da plena humanidade e das perspectivas da vida terrena de Cristo.

Paul Gavrilyuk adverte que tal abordagem é insuficiente por uma série de fatores. Um destes motivos é a alusão àquilo que costumeiramente chamam de "escolas" referindo-se a quatro entidades diferentes: uma escola catequética de Alexandria, uma escola monástica de exegese nas proximidades de antioquia, uma tradição teológica circunscrita determinada área geográfica e um grupo leal a determinado teólogo. Mas estes grupos não mostram suficiente continuidade teológica. Vejamos, por exemplo, o que afirma Gavrilyuk sobre a escola catequética de Alexandria e a escola monástica próxima a Antioquia, respectivamente:

A escola catequética de Alexandria teve uma relação ambígua com o origenismo e sofreu um grave transtorno durante a crise ariana. A peculiar articulação que fez Atanásio da doutrina da encarnação contrasta fortemente com a tendência ao subordinacionismo de Orígenes e com sua característica liberalidade no uso da allegoresis ${ }^{485}$.

Com relação ao asketerion próximo a Antioquia, é muito pouco o que sabemos com segurança sobre o seu mestre e sobre os primeiros anos da escola. Conhecemos que dela saíram duas figuras colossais, João Crisóstomo e Teodóro, o Intérprete. Entre a cristologia de João e a de seu amigo íntimo, logo bispo de Mopsuésia, não há nenhum traço em comum. Não cabe exagerar até que ponto a cristologia dos dois sujeitos de Teodoro é devedora a Diodoro de Tarso. Não há dúvida, tampouco, de que a cristologia de Teodoro recebeu um apoio considerável em Antioquia ${ }^{486}$.

Para Gavrilyuk, a teoria das duas escolas é muito mais que uma mera observação de que cada epíscopo possuía um grupo de teólogos que o acompanhava e lhe servia de apoio. Para ele a referida teoria se propõe a explicar as principais diferenças em termos de influências filosóficas e métodos de exegeses contrários, mas que se associam em certos momentos. Influências filosóficas que hoje se sabe que na antiguidade não eram uma opção, como é o caso do aristotelismo, por exemplo. A suposta influência dos peripatéticos sobre a escola de Antioquia e não do platonismo tardio é pura ficção. Pois estudos recentes revelam que o platonismo tardio também influenciou a escola de Antioquia. Logo, a teoria das duas escolas teria equívocos que partem de seus princípios. Pois tanto Nestório quanto Cirilo teriam sido influenciados pelo platonismo tardio ${ }^{487}$. Além disso, Gavrilyuk acredita que as influências filosóficas,

485 GAVRILYUK, P. El sufrimiento de Dios impassible., p.174.

486 lbid.

487 GREER, R. A. Theodore of Mopsuestia., pp.45.152. Nesta publicação, Rowan Greer demonstra que Teodoro de Mopsuestia, mentor de Nestório, era uma espécie de fundamentalista bíblico, em cuja teologia dominava a imagem bíblica, e não os supostos metafísicos oriundos dos filósofos. $\mathrm{O}$ 
ainda que divergentes, não bastariam para explicar as diferenças cristológicas entre ambos. O mesmo diga-se das supostas diferenças entre seus métodos exegéticos da Bîblia. Antes de tudo é preciso considerar que Cirilo foi bastante prudente na aplicação do método alegórico ao longo de seus volumosos comentários das Escrituras. E o que é mais importante durante o debate com Nestório: Cirilo não se serviu da analogia para analisar os textos cristológicos mais importantes. Foi ele, inclusive, quem levou o significado literal do cântico de Filipenses 2,5-11 até os limites lógicos e o converteu em chave de interpretação do mistério da encarnação ${ }^{488}$.

Assim, nesta segunda via cega de Gavrilyuk, resta-nos admitir que a marca interpretativa da teoria das duas escolas é a observação, ainda que bastante básica, de que Cirilo segue a teologia nicena em sua forma atanasiana, enquanto Nestório é percebido como discípulo e seguidor de Teodoro, seu mentor teológico.

Já a terceira via cega, ao contrário das duas primeiras, não foca em fatores externos, sejam eles políticos ou filosóficos. Mas sim em uma questão teológica, segundo a qual a essência exata da união entre divindade e humanidade constituía o centro da controvérsia nestoriana. A partir daí se estabelecem uma série de distinções técnicas em função das quais a união pode compreender-se dos tipos prosópica, hipostática, natural, essencial, moral, voluntarista e conjuntiva ${ }^{489}$.

Ainda que tal abordagem não seja totalmente equivocada, ela também não é suficientemente esclarecedora, devido a frequência e a gama de situações em que os termos acima aludidos eram, então, utilizados no século V. "O fato de que Cirilo trocava amiúde os termos physis, hypostasis e prosopon, demonstra que qualquer explicação baseada em estritas distinções entre estes termos é anacrônica"490.

Com efeito, é mister encontrar uma maneira mais apropriada para interpretar a insistência de Cirilo, de que a unicidade da pessoa de Cristo não possui modelos porque é mistérica. Para Gavrilyuk, o uso de adjetivos abstratos como "prosópico" ou "natural", tende a obscurecer ainda mais a questão, haja vista que tais adjetivos eram aplicados em sentido mutuamente excludentes pelas escolas adversárias.

Uma vez reconhecidas estas vias cegas, Paul Gavrilyuk propõe um novo ponto de partida.

autor defende que Nestório teria traído seu mestre e sido, a semelhança de Cirilo, vítima da nociva influência do platonismo tardio.

488 GAVRILYUK, P. Op. cit., p.176.

489 lbid.

490 lbid., p.177. 
Sustentarei que Teodoro e Nestório foram, essencialmente, teístas dispostos a proteger a todo custo a impassibilidade absoluta de qualquer participação nos turvos lances da vida humana. Em vista a este propósito central desenvolveram uma versão da encarnação baseada nos dois sujeitos. Para Cirilo, ao contrário, o ponto de partida era o auto despojamento voluntário de um único sujeito divino que aceitou as limitações da vida humana ${ }^{491}$.

\section{2 .2}

\section{A impassibilidade divina no arianismo e no nestorianismo}

Paul Gavrilyuk reconhece uma certa afinidade entre as conceptualizações arianas e nestorianas no que tange a transcendência da divindade. Para Ário, Deus permanece perfeitamente impassível durante a encarnação. Ele acreditava que era impossível que Deus se envolvesse no sofrimento humano e conservasse ao mesmo tempo sua divindade sem nenhum prejuízo. Neste sentido, Deus não poderia ter criado o mundo diretamente, pois realiza todas as suas obras através de intermediários. Logo a distância entre Deus altíssimo e as suas criaturas, não foi superada durante a encarnação.

Teodoro e Nestório também buscam proteger a impassibilidade divina. Defendem uma distância insuperável que separa o criador da criatura, o temporal do eterno, o corruptível do incorruptível ${ }^{492}$. Tal postura será seguida por toda a tradição patrística. Gravilyuk recorda que esta profunda admiração perante a transcendência e o mistério de Deus é marca não somente da religiosidade nestoriana, como também dos cultos ariano e ortodoxo. Para ele, Teodoro se destaca de seus predecessores pela maneira como promoveu a clássica distinção patrística até o seu mais alto grau lógico. Pois concebia que a ação divina durante a encarnação, não tornou Deus mais próximo da criação em um sentido qualitativo; mas apenas quantitativo, haja vista que o homem Jesus foi o primeiro a ser declarado digno da inhabitação pelo Espírito Santo em uma medida superior do restante da humanidade. Isto porque Jesus, como homem eleito, teria melhores dotes morais que os demais homens, superando-os em virtudes ${ }^{493}$.

Gavrilyuk ainda recorda que para Nestório era importante insistir na distinção das duas naturezas, a fim de prevenir a atribuição das ações divinas e das dores humanas ao mesmo sujeito.

A conjunção dos sujeitos divino e humano no Cristo teria que ser concebida na linha da diferença ontológica entre criador e criatura. É absolutamente

\footnotetext{
491 lbid., p.178.

492 GREER, R. A. Theodore of Mopsuestia., p.37. O autor percebe que a postura de Teodoro é de índole mais bíblica, ao mesmo tempo que critica Cirilo e Nestório por terem se deixado influenciar pelo platonismo ao distinguir as naturezas humana e divina.

${ }^{493}$ GAVRILYUK, P. El sufrimiento de Dios impassible., p.179.
} 
necessário, insistia Nestório, começar por proclamar a distinção das naturezas ao aproximar-se do problema da encarnação. Somente assim podemos prevenir a atribuição das ações divinas e das dores humanas no mesmo sujeito. O homem assumido e o Deus que o assumiu hão de distinguir-se claramente ${ }^{494}$.

Para Teodoro, a comunicação entre os sujeitos seguia sempre o mesmo sentido. A divindade poderia comunicar suas propriedades à humanidade mutável, contudo, sem poder participar de suas propriedades. Neste sentido, a divindade de Cristo permanecia impermeável às experiências da encarnação. Ora, o nestorianismo parte exatamente da teologia de Teodoro, propondo uma clara delimitação das ações e propriedades que corresponderiam distintamente a cada um dos sujeitos em Cristo.

Assim, a tradição nestoriana rechaça qualquer possibilidade da natureza divina participar do sofrimento humano. Os nestorianos não aceitavam que Deus pudesse de alguma maneira transgredir sua impassibilidade, de modo que 0 sofrimento era o limite da participação da natureza divina nas experiências humanas. Este pensamento oferecia dificuldades ao entendimento das propriedades correspondentes a cada sujeito, e provocava até mesmo um questionamento a respeito da integridade da divindade de Cristo. É o caso de afirmações de Apolinário, em certas ocasiões, e Cirilo, em que a divindade e a humanidade de Cristo formavam uma só physis, posição que se coloca a caminho de uma anulação da diferença entre os sujeitos.

Portanto, podemos perceber que apesar das diferenças cristológicas, o tema da impassibilidade divina é abordado de modo semelhante nas teologias nestoriana e ariana. Pois para ambas a teoria da impassibilidade excluía a participação direta de Deus em qualquer realidade relacionada com as experiências associadas à fraqueza humana. Mas, tal aproximação não era fruto de influência filosófica, mas do movimento de oposição a correntes filosóficas que vinham de encontro à distinção patrística entre criador e criatura.

Uma participação tão íntima seria indigna de Deus e destrutiva para a criação. Devemos observar que esta aproximação não partiu de ideias filosóficas, mas da distinção patrística entre criador e criatura, surgida em oposição consciente ao materialismo monista estóico, ao emanacionismo platônico, ao dualismo metafísico em suas várias formas, e a todas as demais propostas cosmológicas daqueles tempos. A preocupação central da religiosidade e da teologia nestorianas era purificar o discurso teológico de tudo o que pudesse sugerir sofrimento divino ${ }^{495}$.

\footnotetext{
494 Ibid

495 lbid., p.181.
} 


\title{
6.2.3
}

\section{A Theopatheia de Cirilo}

Nestório, objetivando proteger a impassibilidade absoluta da divindade,

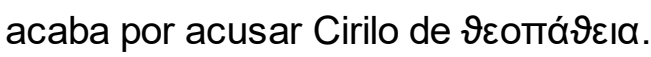

Tu (Cirilo) pensavas que (os Padres) haviam dito que a Palavra, que é coeterna com o Pai, é capaz de sofrer. Se és tão amável, serve melhor o significado preciso de tuas palavras, que encontrarás que o inspirado coro dos Padres não diz que a divindade consubstancial fora capaz de sofrer, nem que esta divindade, coeterna com o Pai, fora engendrada, nem que esta divindade voltara dentre os mortos quando, a partir dos escombros, reconstruiu seu templo ${ }^{496}$.

O fragmento acima refere-se ao primeiro ataque teológico dirigido por Nestório em Ad Cyrillum, em que acusa Cirilo de ter mal interpretado o segundo artigo do credo ao atribuir as experiências humanas de Cristo, incluindo seu sofrimento e morte, a Deus Verbo. Mas Nestório não para por aí. Ainda no exílio seguia com a acusação usando a mesma argumentação.

\begin{abstract}
Eles (os cirilianos) tomam tudo o que há na natureza e o atribui naturalmente ao Deus Verbo: o medo humano e a traição, o interrogatório, a resposta, os golpes na face (...). É certamente terrível e espantoso pensar como eles; e contar aos homens os tipos de pensamentos que eles guardam sobre o Filho, quem foi criado e feito, e mudado de impassível para passível, e de imortal para mortal e de imutável para mutável ${ }^{497}$.
\end{abstract}

A acusação de que Cirilo teria descartado a impassibilidade divina foi adotada como bandeira pelo partido oriental que apoiava Nestório. Gavrilyuk recorda que a segunda e terceira cartas de Cirilo a Nestório foram acolhidas pela grande maioria dos Padres do concílio efesino de 431, mas muitos deles foram contrários aos doze anátemas que acompanharam a terceira carta. Gavrilyuk afirma que não se sabe com exatidão se esses anátemas eram ou não um reflexo preciso das opiniões da lgreja em geral. Pois tal questão foi debatida durante cem anos, até a sua canonização no Concílio de Constantinopla II. Mas notório é o fato do Concílio de Éfeso ter partidários entusiastas aos anátemas, tais como Acácio de Malitene e Proclo, futuro bispo de Alexandria ${ }^{498}$. De qualquer modo, Cirilo teria que se explicar a respeito de seus anátemas.

Como Cirilo e Nestório estavam em prisão domiciliar em Éfeso, o imperador Teodósio II ordenou que duas delegações, formadas por representantes de ambos os epíscopos, fossem a Constantinopla a fim de defendê-los. Contudo, apesar do

\footnotetext{
496 NESTÓRIO. Ad Cyrillum, II, 3 Apud WICKHAM, L.R. Cyril of Alexandria., p.36.

497 Liber Heraclidis, 1.2 Apud GAVRILYUK, P. El sufrimiento de Dios impassible., p.182.

498 RUSSEL, N. Cyril of Alexandria., pp. 175-176 In GAVRILYUK, P. Op.cit.
} 
imperador mostrar-se inclinado ao partido de Nestório, o descontentamento popular na capital contra este era tão forte, que o imperador não poderia ser guiado por critérios unicamente teológicos. Assim, conforme foi se desenvolvendo as negociações, Cirilo foi reconduzido à sede de Alexandria, enquanto Nestório, ainda deposto, foi reconduzido ao seu antigo monastério de Antioquia.

Ora, não podemos perceber Nestório puramente como um leviano herege que deseja dividir a lgreja. O referido hierarca segue o afã da tradição patrística de buscar uma linguagem apropriada para descrever de maneira não menos apropriada a participação de Deus no mundo. Ele acreditava firmemente que o único modo de participação digna de Deus era aquela que em nada afetasse ou diminuísse atributos de sua perfeição divina, tais como a impassibilidade e a imutabilidade. Nestório queria eliminar do discurso teológico toda conotação de sofrimento divino. Considerava que a cristologia do "Deus no ventre - Deus na tumba" era um resíduo de impassibilidade bárbara ${ }^{499}$.

Para Nestório, sofrer e morrer são fatos humanos. Isso seria o que há de mais indigno para Deus. Sua acusação favorita a Cirilo e aos seus seguidores era a de theopatheia, em Liber Heraclidis. Ainda no fim de sua vida escreveu um tratado intitulado Adversus Theopaschitas, do qual nos chegam apenas fragmentos. Aí se percebe que as críticas de Nestório nunca mudaram substancialmente ao longo de toda controvérsia, tanto que ele nunca deixou de acusar Cirilo de pregar um Deus sofredor. Segundo Nestório, Cirilo não somente afirmava que a natureza de Deus continha traços antropomórficos, mas era vulnerável à dor e à mortalidade. Mesmo quando admitia a impassilbilidade da natureza divina, Cirilo atribuía a Deus todas as experiências humanas da encarnação; ou quando lançava mão do aforismo "Deus sofreu impassivelmente", queria de fato, conforme acusação de Nestório, dissimular o verdadeiro propósito dos alexandrinos, isto é, abandonar a impassibilidade divina.

Aqueles que passam por ortodoxos (...) por palavras Lhe atribuem uma natureza imutável, impassível e sem carência, mas Lhe adscrevem todos os sofrimentos e carências do corpo, enquanto reservam todas as coisas da alma e da inteligência a Deus Verbo em virtude de uma união hipostática ${ }^{500}$.

Nestório compreendia que admitir a participação do Filho no sofrimento, como Cirilo defendia, fatalmente levava à conclusão lógica de que o Filho não era da mesma essência do Pai, ou pelo menos uma parte de sua natureza impassível havia se despreendido no momento da encarnação. Nestório queria de fato provar

\footnotetext{
499 GAVRILYUK, P. El sufrimiento de Dios impassible., pp.182-184.
}

500 NESTÓRIO DE CONSTANTINOPLA, Liber Heraclidis, 1,2. 
que o pensamento de Cirilo, segundo o qual a Palavra sofreu na carne, flertava perigosamente com arianismo, como também era muito próximo às teses de Apolinário ${ }^{501}$.

Gavrilyuk, seguindo a tese de Paul Galtier em Saint Cyrille et Apollinaire, afirma que verdadeiramente existe uma forte proximidade entre os doze anátemismos de Cirilo e alguns escritos do círculo apolinarista, que Cirilo, ignorando sua origem, julgava por ortodoxos. Cirilo, evidentemente, conhecia a condenação imposta pelo Concílio de Constantinopla I de 381 a Apolinário. Por isso, percebe-se um considerável esforço de Cirilo para se afastar das teses apolinaristas, segundo as quais o Logos superou no Cristo a mente e a alma racional. Contudo, tais esforços não foram suficientes para fazer Nestório recuar em suas acusações, insistindo que Cirilo, ao atribuir experiências humanas à Palavra divina acabava por se aliar ora ao arianismo, ora ao apolinarismo ${ }^{502}$.

Nestório afirmava que 0 aforismo de Cirilo "A Palavra sofreu impassivelmente" era, senão uma contradição, uma blasfêmia.

E como os que mudam sua natureza, eles primeiro O chamam impassível e imortal e imutável, e logo proíbem que O chamem impassível e imortal e imutável, e se enojam com todos aqueles que insistem em chamar a Deus de Palavra impassível ${ }^{503}$.

A clara distinção entre as duas naturezas, segundo Nestório, seria capaz de resolver de forma simples e efetiva todas as ambiguidades e contradições da cristologia de Cirilo. Mas o Bispo de Alexandria não fez a dita distinção com a clareza e firmeza necessárias. Logo, deve ser considerado teopasquita.

Diante do que foi exposto até aqui no que diz respeito à controvérsia nestoriana que precedeu o Concilio de Calcedônia, Paul Gavrilyuk propõe os seguintes questionamentos: Nestório estava realmente certo ao acusar Cirilo de teopasquia? Em que sentido Cirilo era teopasquita? Até que ponto a inspiração kenótica da cristologia ciriliana foi capaz de influenciar a cristologia posterior da lgreja? Questões difíceis de serem respondidas, e cujas respostas, conforme Gavrilyuk, não podem ser encontradas nem mesmo na obra de Cirilo.

Paul Gavrilyuk adverte que pouco adiantaria avaliar a cristologia de Cirilo pelo grau de distanciamento do axioma filosófico da impassibilidade divina. Para uma reta avaliação, há que se supor uma dicotomia entre o Deus bíblico que sofre e o Deus filosófico que não sofre. Pela própria acusação de Nestório, percebemos

\footnotetext{
501 lbid.

502 GAVRILYUK, P. El sufrimiento de Dios impassible., pp.185-186.

${ }^{503}$ NESTÓRIO DE CONSTANTINOPLA, Liber Heraclidis, 1,2.
} 
que Cirilo não compreendia a impassibilidade e a passibilidade divinas como realidades inconciliáveis. Até mesmo os autores bíblicos viam na atribuição de emoções e experiências humanas a Deus um problema de antropomorfismoe não propriamente uma ameaça sobre as atribuições não antropomórficas de Deus. Cirilo, porém, sabia que o problema do antropomorfismo frequentemente vinha à tona em sua obra. "Ele estava certo de que afirmar sem maiores precisões a passibilidade da natureza divina era como abrir uma caixa de Pandora teológica" ${ }^{504}$.

Na esteira da teologia apofática dos Padres, Cirilo compreendia um uso apropriado e outro inapropriado da impassibilidade divina. Com efeito, os padres não excluíam as características divinas que se manifestavam de modo emocional, e tampouco a implicação de Deus no criado. Assim, Gavrilyuk acredita que para Cirilo uma profunda teologia da encarnação precisa fazer uso tanto da impassibilidade quanto da passibilidade devidamente qualificadas. Tomar partido pela impassibilidade era assegurar a verdade de quem verdadeiramente se encarnou foi Deus. E afirmar uma passibilidade qualificada era sustentarque Deus verdadeiramente se submeteu às condições da encarnação. Já Nestório, entendia que a impassibilidade atuava de uma maneira bastante distinta, ou seja, excluía qualquer participação divina no sofrimento humano por considerá-la absolutamente indigna de Deus ${ }^{505}$.

\section{2 .4}

\section{O Verbo unigênito de Deus, sujeito da kênosis}

Gavrilyuk percebe que Cirilo compreendia que o caminho de acesso ao verdadeiro significado do artigo cristológico do credo se encontra no Cântico de Filipenses 2, 5-11. Esta era sua norma: toda interpretação da encarnação tem que fazer jus a Fp 2,5-11. Em sua terceira carta a Nestório, ele insiste na expressão "esvaziou-sea si mesmo" presente no referido cântico: "E declaramos que o Verbo unigênito de Deus que (...) desceu para a nossa salvação, esvaziando-se a si mesmo, é quem se encarnou e se fez homem, isto é, tomou a carne da santa Virgem, e a fez sua desde o ventre" ${ }^{506}$.

O sujeito e as propriedades da kênosis são, na visão de Gavrilyuk, as chaves de interpretação das numerosas exposições que fez Cirilo a respeito de Fp 2, 5-

\footnotetext{
${ }^{504}$ GAVRILYUK, P. Op. cit., p.188.

505 Id. Theopatheia., pp 190-207.

506 CIRILO DE ALEXANDRIA. Ad Nestorium, III, 3 Apud GAVRILYUK, P. El sufrimiento de Dios impassible., p.189.
} 
11. Teodoro em De Symbolo já havia distinguido aquele que tinha forma de Deus daquele que tinha forma de escravo. Ora, Nestório em Ad Cyrillum, seguindo seu mestre, sustentou que o sujeito da kênosis era aquele que tinha forma de escravo, ou seja, um homem passível habitado pelo Verbo. Um homem portador de Deus, digno de adoração e de culto juntamente com o Deus que nele habitava. Este homem portador de Deus padeceu, foi esvaziado de vida humana e morreu. Assim, os seguidores de Nestório acreditam que qualquer participação de Deus no esvaziamento fatalmente violaria sua impassibilidade.

Evidentemente, a tese de Cirilo vai de encontro ao que foi posto. Toda a sua teologia foi um verdadeiro esforço para proclamar que algo único e absolutamente incomparável havia acontecido na encarnação. De modo que ver em Cristo um homem comum como todos os outros, mesmo que ele seja o portador de Deus, impedia Teodoro e Nestório de penetrar no coração do Evangelho. À semelhança de Teodoro, Nestório acreditava que o modo como Deus habitou no homem Jesus era diferente apenas qualitativamente do modo como ele habitou nos santos e profetas do Antigo Testamento. Segundo ele, Deus teria escolhido habitar nos santos por boa vontade e porque estes eram dignos de sua presença. Portanto, Jesus superava a todos os demais homens em conhecimento e virtude, e por isso era digno de que Deus habitasse nele no mais alto grau.

Já Cirilo, seguindo a cristologia de Atanásio, distinguia a presença de Deus em Cristo e nos homens deificados somente em um nível qualitativo. Para ele, a forma nestoriana de entender a união de naturezas em Cristo não fazia jus a Jo 1,14 , pois o evangelista não diz que o Verbo se transformou em carne, mas que se fez carne, justamente para excluir qualquer ideia de habitação relativa. De fato, a diferença entre Cristo e os santos e profetas era qualitativa, mas esta sentença cristológica requer um esforço semântico para que a mesma seja muito bem esclarecida. Pois o evangelho não afirma que um homem ordinário nasceu de Maria Sempre Virgem, e que logo o Verbo se depositara simplesmente sobre ele; o que afirma é que o Verbo se submeteu ao nascimento carnal desde o ventre da Virgem Maria. Assim, Cirilo entende que o sujeito de cada afirmação sobre Cristo não era um homem habitado por Deus, mas o Verbo feito carne. Ora, se não há diferença qualitativa entre a santificação dos santos e profetas por parte de Deus e sua participação na vida de Cristo, logo, Deus em cada uma das três pessoas se esvaziou a si mesmo em todas as almas em que habitou. Se o portador de Deus, o homem Jesus, era digno de culto, teriam também que admitir como digno de culto todos os cristãos, haja vista que neles habita o Espírito Santo. É com este pensamento lógico que Cirilo, segundo Gavrilyuk, contra-argumentou a acusação 
de theopatéia, lançando agora, por sua vez, a acusação de antropolatria. Além disso, a cristologia do homem que porta a Deus levaria à controvertida conclusão de que todos aqueles que são habitados pelo Espírito Santo são corpos doadores de vida, e não somente o de Cristo ${ }^{507}$.

Gavrilyuk recorda que a atribuição exclusiva do esvaziamento do ser humano também dava margem a outro problema que Cirilo abordou por diversas vezes, a saber, que a natureza humana já é débil e vazia, não podendo, portanto esvaziar-se do que não possui. Cirilo lançando mão de 2 Cor 8,9, observa que a humanidade era completamente pobre aos olhos de Deus, e por isso mesmo não podia empobrecer-se ainda mais.

\begin{abstract}
Só aquele em quem Deus habitava plenamente pode esvaziar-se, só quem era rico estava em posição de desprender-se de suas riquezas para beneficiar a outros. O esvaziamento de um mero homem não era esvaziamento em absoluto. O notório anátema décimo segundo se dirigia especificamente contra aqueles que iam

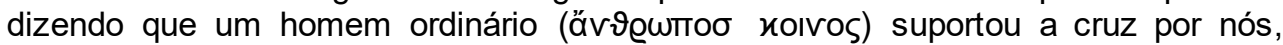
como Cirilo declarou em sua Explicatio duodecim capitum, obra escrita durante sua prisão domiciliar em Éfeso, no verão de $431^{508}$.
\end{abstract}

Contudo, Teodoro e Nestório nunca haviam afirmado que Cristo foi somente um homem. Tanto que os cristãos orientais dos tempos de Teodoro tiveram que enfrentar violentos ataques do arianismo por sua fidelidade ao Concílio de Niceia. Assim, qualquer acusação por parte de Cirilo que estivesse nesse nível, seria facilmente desfeita pelo próprio testemunho da comunidade oriental nos tempos de Teodoro. A esta acusação Gavrilyuk chama de objeção psilantrópica ${ }^{509}$.

Como temos visto até aqui, Teodoro e Nestório, em sua aventura intelectual em proteger a impassibilidade divina, distinguiam taxativamente dois sujeitos distintos das experiências e ações de Cristo. Porém, sua argumentação convertia um homem num único sujeito do auto esvaziamento. E para Cirilo, os nestorianos tinham passado dos limites em seu piedoso afã em salvaguardar a dignidade de Deus.

Incapazes de espreitar o plano de Deus, tratam com malícia de imputar o sofrimento ao homem unicamente, em tola observância de uma religião falsa. Seu objetivo é que na Palavra de Deus não reconheçamos o Salvador que deu seu sangue por nós, e que seja somente Jesus, visto como um indivíduo isolado a quem honram. 510

Paul Gavrilyuk entende que Nestório e Cirilo seguem sua controvérsia por uma linguagem de atributos negativos - já que a Palavra nunca abandonou sua

${ }^{507}$ Estes argumentos se encontram em CIRILODE ALEXANDRIA, Scholia, 18,24 e explanados por GAVRILYUK, P. El sufrimiento de Dios impassible., pp.189-191.

508 lbid., p. 192.

509 lbid.

${ }^{510}$ Ad Succensum, 4 Apud GAVRILYUK, P. Op. cit., p.193. 
condição divina - para expressar, cada um de acordo com o seu interesse, o mistério da encarnação. Porém ambos admitiam que na encarnação algo de novo e incomparável ocorreu, de modo que somente a partir desta novidade é possível atribuir experiências humanas ao Verbo de Deus no âmbito da lógica da encarnação. Porém, é sem dúvida Cirilo quem expressa de modo mais apropriado que Deus em sua onisciência conhecia a nossa debilidade, e dela participa pelo evento da encarnação. Neste sentido, é possível falar em Cirilo de uma aceitação totalmente única das limitações humanas por parte do divino.

Todavia, o "x" da questão para Gavrilyuk, não é saber quem de fato está com a razão. Mas questionarmos se Cirilo e Nestório coincidiam ou não no fato de que no auto esvaziamento não se podia entender uma corrupção da divindade. Mas ainda: entender porque era preciso assegurar que o esvaziamento tinha um só sujeito indiviso e em que consistia este esvaziamento. Ora, Nestório, seguindo

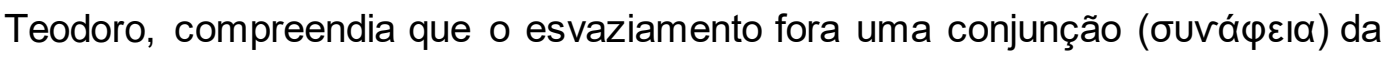
humanidade e do Verbo divino. Já Cirilo respondia que conjunção era algo que qualquer ser humano poderia ter com Deus, unindo-se a ele pela prática das virtudes e pela pureza. Se Teodoro, afirmava que a conjunção era não mais que uma anexação da humanidade ao divino, em que por esvaziamento se entendia as experiências que só podiam ser atribuídas ao homem assumido por Deus, e não o contrário. Cirilo respondia que o esvaziamento não consistiu unicamente na anexação da humanidade a uma divindade inalterada. Pelo contrário, a encarnação significava que Deus desceu aos limites da humanidade e permitiu que as limitações ( $\mu \varepsilon ́$ т९oı) humanas exercessem seu domínio sobre ele. De maneira que a submissão do Verbo às limitações da existência humana implicavam uma série de restrições temporais ao seu poder divino. ${ }^{511}$

Gavrilyuk recorda que Cirilo de fato pregava que o Verbo durante a encarnação permaneceu impassível na sua própria natureza. Mas nosso autor também adverte que os historiadores da teologia, que defendem a teoria da queda da teologia na filosofia helênica, querem ver aí uma prova de que Cirilo abandonou sua postura radicalmente teopasquita e acabou por fazer as mesmas concessões que os nestorianos ao axioma da impassibilidade. Segundo esta leitura dos fatos, Nestório era um impassibilista filosófico perfeitamente consciente, e Cirilo um teopasquita pelo menos ambíguo. Para Gavrilyuk, se não fosse por suas alianças filosóficas desviantes, Cirilo teria visto a luz e teria se unido aos círculos daqueles que hoje defendem um sofrimento divino irrestrito..$^{512}$

${ }^{511}$ GAVRILYUK, P. Op. cit., p.197.

512 Ibid., p.198. 
Para Paul Gavrilyuk, os teólogos patrísticos têm opiniões bastante díspares quanto ao que temos visto até aqui, podendo ser divididos entre "biblicistas", "teopasquitas" e impassibilistas. Como já vimos, o impassibilismo nestoriano representa um tipo particular de fé inspirado na visão escriturística da diferença ontológica entre criador e criatura. Já Cirilo, por sua vez, nunca se opôs a dissolução do paradoxo da encarnação por razões filosóficas, porém, objetivava desenvolver uma versão definitivamente cristã da intervenção divina.

Sendo assim, a tese a qual se inclinam os teopasquitas contemporâneos, segundo a qual a divindade desnuda, ou Deus mesmo não encarnado, sofre, possui duas questões complicadas: 1) as atribuições antropomórficas aplicadas a Deus o tornam passível e capaz de sentir emoções humanas antes mesmo da encarnação, 2) se a natureza divina pode sofrer por si, ou seja, como os homens, mas sem assumir a forma humana, logo, a encarnação perde seu sentido, tornase desnecessária ${ }^{513}$.

Para Gavrilyuk, Cirilo compreende muito bem a sutileza de toda a questão. E por isso mesmo, quando afirma que o Verbo sofreu impassivelmente, ele longe de querer pregar um Deus impávido e distante durante a encarnação, quer na verdade repudiar qualquer tese deste matiz. Cirilo queria afirmar que quem de fato se submeteu às limitações da encarnação e aceitou todas as consequências que Ihes são próprias, foi sem dúvida alguma um sujeito divino, que, conforme afirma o Novo Testamento, é tão impassível quanto passível. Sua intenção é clara: sustentar tanto a divindade irredutível de Cristo, quanto a participação de Deus nas experiências humanas na encarnação. Neste sentido, para Cirilo, Deus não sofreu na natureza divina, mas sim na natureza humana. De modo que a carne foi um instrumento que permitiu ao Verbo sofrer humanamente.

Por fim, Nestório argumentou que Cirilo, com sua tese de que Deus sofreu em uma outra natureza, acabava com o problema, mas não o resolvia. A impassibilidade divina era absolutamente incondicional e inegociável para Nestório, pois aquele que não sofria em sua própria natureza, não podia sofrer em outra. Para contestar esta alegação de Nestório, Cirilo desenvolveu a tese de Atanásio de apropriação das características humanas por Deus, utilizando-se de várias analogias para alentar sobre a participação divina no sofrimento da carne. ${ }^{514}$ Para Cirilo, o auto esvaziamento divino significa Deus mesmo que faz da sua vida humana sua própria vida. Da mesma forma, a kênosis é a apropriação de características humanas. Sem esta solidariedade de Deus às limitações da vida

513 lbid.

514 Ibid., p.201. 
humana, como sede, fome, cansaço, ignorância, medo e morte, o auto esvaziamento de Cristo seria sem sentido.

\title{
6.2 .5
}

\section{A impassibilidade divina e a construção da doutrina da encarnação}

Para Paul Gavrilyuk, só é possível uma reta compreensão das categorias lógicas da teologia patrística, quando nos dispomos a purgar de nossa consciência histórica todo pressuposto da teoria segundo a qual a teologia teria caído ou se associado à filosofia helênica, haja vista que um enfoque interpretativo deste tipo tenderia a desvirtuar a teologia patrística da participação divina no sofrimento. Pois, ao contrário do que se pode pensar, no mundo helênico não havia nada semelhante a um axioma da impassibilidade divina.

\begin{abstract}
As escolas pagãs de filosofia apresentavam concepções incompatíveis da natureza divina, assim como das emoções e da intervenção divina no mundo. Além disso, a imagem de Deus que a Bíblia apresenta está longe de ser irrestritamente passibilista: a tensão entre transcendência e participação na história é essencial ao cânon bíblico. A teologia patrística não teria que eleger entre a deidade apática dos filósofos e o Deus sofredor da Bíblia, porque estas concepções de Deus não são mais que construções intelectuais errôneas, e não as verdadeiras opções de que dispunham os teólogos da antiguidade tardia. A doutrina da encarnação que a lgreja desenvolveu era distinta de tudo o que o pensamento helenista poderia oferecer ${ }^{515}$.
\end{abstract}

Ao longo da obra O sofrimento de Deus impassível, Paul Gavrilyuk sustenta que a postura da lgreja ao longo das principais heresias cristológicas, foi se construindo através de uma série de manobras dialéticas, que objetivava antes de tudo salvaguardar uma certa noção de intervenção divina que se deveria considerar digna de Deus. Por estas referidas manobras dialéticas, a lgreja foi repudiando uma a uma das três estratégias equivocadas que pretendiam eliminar a tensão entre a condição divina de Cristo e as experiências humanas de sua vida terrena.

Tal tensão, que constitui o coração do mistério da encarnação, foi capaz de produzir três manobras que objetivavam dissolvê-la e que ao longo da história cristã adquiriu matizes diferentes. São elas: 1) negar a realidade das experiências humanas de Cristo; 2) renunciar à condição divina de Cristo; 3) afirmar que as ações divinas e as experiências humanas correspondem a dois sujeitos diferentes. Tais manobras foram eleitas por docetistas, arianos e nestorianos, respectivamente. Estes tinham em comum a ideia de que a impassibilidade excluía a participação direta da divindade no sofrimento e sua intervenção na

\footnotetext{
515 Ibid., p.213.
} 
história. Para Gavrilyuk, docetistas, arianos e nestorianos afirmavam uma impassibilidade divina sem matizes e sem restrições. Sustentavam que as experiências humanas eram indignas de Deus e não podiam se atribuídas a Ele sem diminuir a integridade da natureza divina.

Gavrilyuk recorda que os teólogos ortodoxos, pelo contrário, consideravam que a impassibilidade divina matizada era compatível com certas emoções adequadas a Deus e com o sofrimento do Verbo encarnado. A impassibilidade, segundo nosso autor, era para os ortodoxos, sinal inquestionável de identidade divina ${ }^{516}$.

Os docetistas consideravam a crucificação uma ofensa à fé pagã. Metafisicamente era impossível que a suprema deidade fosse afetada diretamente pela maldade do mundo material. Para eles a impassibilidade divina excluía qualquer possibilidade de Deus participar dos sofrimentos humanos. Pregavam que as experiências de Cristo eram putativas e não de fato. A lgreja se opôs radicalmente a esta heresia e insistiu que a realidade do sofrimento de Cristo era inegavelmente histórica e soteriológica. A tradição apostólica, a liturgia da lgreja e o sacrifício dos mártires proclamam a realidade da crucificação e sua vital importância para a fé.

Os arianos, que representam a segunda fase do processo teológico de construção da doutrina da encarnação, ao desejar dissolver o paradoxo da encarnação, ao contrário dos docetistas e em reação à posição patripassionista, afirmavam uma estrita divisão entre o Deus impassível e o Lógos passível. Para os arianos, o Lógos deveria ser mais que um simples homem, para que seu sofrimento tivesse efeito soteriológico universal, mas também ser menos que o Deus altíssimo, para poder se desenvolver e sofrer. Ao fim desta controvérsia a Igreja no Concílio de Niceia declarou que sem dúvida alguma o Cristo, Filho de Deus, isto é, da mesma substância do Pai, desceu, se encarnou e se fez homem, padeceu e ressuscitou ao terceiro dia para a nossa salvação, de modo que a lógica desta referida salvação, requeria a plena divindade de Cristo. Com isso, a Igreja elevou a tensão entre a identidade divina de Cristo, cuja marca era a impassibilidade, e suas experiências humanas a níveis até então desconhecidos. Logo, era inevitável que a questão retornasse com ímpeto renovado nos decênios seguintes. Os teólogos pró-nicenos apenas deram indicações parciais para solucionar o problema, porém, foi com a controvérsia nestoriana que a questão recebeu uma atenção sistemática.

\footnotetext{
516 Ibid., p.214.
} 
Os nestorianos, por sua vez, trataram de resolver a questão distinguindo dois sujeitos na narração evangélica: o homem habitado pelo Lógos e o Lógos que habitou no homem. Nestório afirmava que nenhuma forma de mudança, ou desenvolvimento e sofrimento poderia ser própria do Lógos. Deste modo, todas as experiências próprias da encarnação ou humanas deveriam ser atribuídas ao homem.

Cirilo de Alexandria, em sua resposta à acusação de theopatheia, percebeu que atribuir sofrimento a natureza divina, levaria a encarnação a uma perda de sentido, pois se a natureza divina pode se submeter às experiências humanas, então porque se uniria a natureza humana? Por outro lado, atribuir sofrimento unicamente à natureza humana significaria diminuir a participação divina. Nestório, como já vimos, optou pela segunda alternativa, ao passo que, para Gavrilyuk, muitos defensores modernos do sofrimento divino tendem a optar pela primeira alternativa ${ }^{517}$. Jürgen Moltmann, por exemplo, cujo esboço cristológico expomos anteriormente, percebe na crucificação a revelação definitiva da identidade divina de Jesus ${ }^{518}$.

Mas para Gavrilyuk, tal pensamento defendido por muitos teólogos contemporâneos cria um outro problema: a desnecessidade da encarnação. Pois se realmente a identidade divina fora definida pela crucificação de uma maneira que sugerisse que foi a própria natureza divina quem sofreu de modo humano, a encarnação resultaria supérflua. Haja vista que deste modo, a carne só estaria duplicando o sofrimento a que o Verbo já estaria submetido em sua própria natureza. Portanto, torna-se mister, e até mesmo crucial, diferenciar aquilo a que o Verbo se submete em sua própria natureza, daquilo que se lhe pode atribuir por virtude de sua apropriação da natureza humana ${ }^{519}$.

O que Cirilo defendeu em sua resposta a Nestório era precisamente esta distinção. Cirilo parte em todas as suas reflexões sobre a encarnação, do auto esvaziamento, que é a restrição do poder divino da Palavra que aceita voluntariamente as limitações da encarnação. A Palavra fez propriamente suas as experiências humanas, mudando-as a partir de dentro: o que nelas havia de violento, involuntário, tragicamente absurdo, fatal para as pessoas normais, o ministério da Palavra o tornou voluntário, soteriologicamente valioso e vivificante. A Palavra que nas alturas não sofre em sua própria natureza padeceu ao apropriar-se da natureza humana e triunfou sobre o sofrimento. A celebração deste paradoxo nos hinos e credos é a realização que culmina uma noção distintivamente cristã da intervenção divina, uma ideia sobre a qual nenhuma escola filosófica pode reclamar uma ascendência exclusiva $^{520}$.

517 Ibid., p.216.

518 MOLTMANN, J. O Deus crucificado.

${ }^{519}$ GAVRILYUK, P. El sufrimiento de Dios impassible., p.216.

520 lbid. 
Para Gavrilyuk, foi Cirilo quem elevou a discussão da doutrina da encarnação, ou mais exatamente da impassibilidade, a um nível nunca antes atingido pelos teólogos patrísticos. Mas, foi com o Concilio de Calcedônia que a discussão chegou ao seu cume. Haja vista que a meta principal da cristologia calcedoniana era manter unidas a divindade e a humanidade de Cristo, bem como a clara distinção de ambas. Para nosso autor, a distinção equivocada entre a humanidade e a divindade, atribuindo experiências humanas diretamente a Deus, têm levado os atuais defensores da passibilidade a afirmar que humanização do Verbo divino seria sem sentido ou pelo menos metafisicamente impossível ${ }^{521}$.

É uma tendência quase que natural do ser humano, ao se empenhar na busca da ciência divina, projetar para Deus atribuições humanas, ou ao menos aplicar-Lhe as nossas categorias. Mas, pelo que temos visto até aqui, Deus, como Deus, não repete o que nós como homens sofremos. Contudo, na encarnação Deus continua sendo Deus, mas participa da condição humana até a dolorosa e humilhante morte de cruz. Permanecendo impassível, Deus assume completamente as experiências de sua natureza humana. Com efeito, para uma abordagem atualizada do Concilio de Calcedônia é mister recuperar a noção de impassibilidade divina, integrando-a de forma mais adequada à reflexão teológica contemporânea sobre o mistério da participação divina no sofrimento do mundo.

\begin{abstract}
Creio que este tema pode ser contemplado sob uma luz diferente. A solidez desta postura reside em sua reserva apofática e em sua amplitude: mais uma vez não se define nenhum modelo da participação de Deus no sofrimento como se fosse normativo ou vinculante, tanto que se rechaçam decididamente a apatia divina e o sofrimento eterno e irredento. Como queira que Deus participe no sofrimento, não é nem eternamente indiferente ao sofrimento, nem eternamente superado por ele. Assim, pois, se reconhecemos o insolúvel paradoxo da transcendência e imanência divinas que está no centro do mistério da participação de Deus no sofrimento, temos uma base para realizar um futuro consenso teológico da questão ${ }^{522}$.
\end{abstract}

\title{
6.3
}

\section{Vladimir Lossky}

A relação divindade-humanidade de Jesus Cristo no horizonte da distinção entre hipóstase e essência está no centro da cristologia de Vladimir Lossky (+1958). Distinção que já caracterizava a cristologia de Máximo, o Confessor que, juntamente com São João Damasceno, influenciou de forma determinante as especulações teológicas de Lossky, tanto que ambos os Padres são constantemente citados em suas obras. Mas, abaixo destacamos algumas razões

\footnotetext{
521 lbid., p.250.

522 Ibid., p.251.
} 
que explicam porque nosso teólogo russo tanto se deixou influenciar pela cristologia de Máximo, o Confessor.

1) Máximo defende a polaridade entre essência e hipóstase; ${ }^{523}$

2) Foi ele também quem elaborou "o pensamento mais avançado da patrística" ${ }^{524}$;

3) Manifestou profundo nexo e coerência entre a cristologia e a sua doutrina trinitária, elaborando uma cristologia no horizonte da doutrina trinitária. Máximo sabe que no Logos encarnado permanece sempre um dos Três divinos, e sendo assim, uma asserção cristológica não pode cancelar uma afirmação trinitária ${ }^{525}$;

4) Por fim, desenvolve a sua reflexão sobre a divina-humanidade de Jesus

Cristo sem nunca negligenciar o lado soteriológico da questão, ou 0 problema da nossa união com Deus ${ }^{526}$;

Vladimir Lossky, ao se debruçar sobre a questão da divina-humanidade de Jesus Cristo, tem por referência a cristologia do Concílio de Calcedônia, haja vista a índole apofática da definição calcedoniana, mais exatamente das quatro expressões negativas que expressam a união das duas naturezas na única

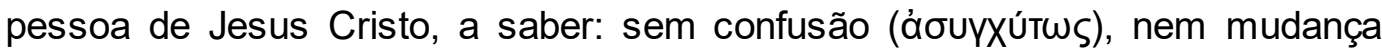

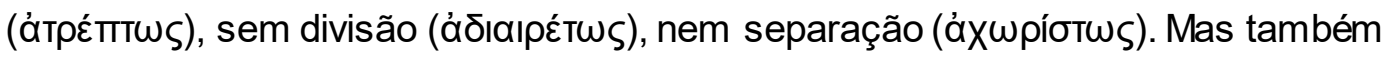
o fato de apesar do conhecimento que temos da união das duas naturezas em uma só pessoa, o "como" dessa união permanece ainda um mistério fundado sobre a distinção-identidade incompreensível da natureza e da pessoa.

Nós conhecemos o fato da união das duas naturezas em uma só pessoa, mas o "como" desta união permanece para nós um mistério fundado sobre a distinçãoidentidade incompreensível da natureza e da pessoa. O Cristo, pessoa divina, será, portanto, em si dois princípios diversos e unidos ao mesmo tempo. Se poderá dizer que o Filho de Deus sofreu, foi morto na cruz, mas de acordo com o que ele poderia sofrer e morrer, de acordo com a sua humanidade ${ }^{527}$.

Segundo Lossky, para compreendermos o sentido e o alcance da definição dogmática calcedoniana é mister examinar a realidade da pessoa de Jesus Cristo como o Filho de Deus, eternamente gerado e, por isso mesmo, pela sua relação de origem, da mesma natureza divina. Lossky nos faz entender que a encarnação em nada diminui a sua identidade hipostática, nem muito menos a unidade da Trindade, ou das Três divinas hipóstases. De modo que a pessoa divina de Jesus

\footnotetext{
523 ŽAK, L. Trindade e imagem., p.111.

${ }^{524}$ BORDONI, M. Gesú di Nazaret Signore e Cristo., p.311.

525 VON BALTHASAR, H. U. Massimo il Confessore, Liturgia cósmica., p.184.

${ }^{526}$ LOSSKY, V. La teologia mística dela Chiesa d'Oriente., p.146.

527 lbid., p.135.
} 
Cristo, Filho de Deus, continua na mesma condição tanto na vida terrena, quanto na eternidade, isto é, a segunda pessoa, mesmo depois da encarnação, continua a se distinguir da natureza comum de Deus, no sentido de que a hipóstase do Filho não se identifica com a do Pai.

Precisamente porque há essa distinção, a segunda pessoa da Trindade, na economia salvífica pode renunciar a si mesma e à sua própria vontade, experimentando o esvaziamento ou a kênosis de si.

Como afirmamos várias vezes, a perfeição da pessoa consiste no abandono. Enquanto distinta da natureza, enquanto "não-natureza", enquanto si mesma, a pessoa se exprime na renúncia a si mesma. É a renúncia da pessoa do Filho, a kênosis divina. "Todo o mistério da economia - disse Cirilo de Alexandria - consiste na renúncia e no abaixamento do Filho de Deus" ${ }^{528}$.

Lossky entende que o Verbo, Filho de Deus, vive kenoticamente, ou seja, renuncia a sua própria vontade para acolher a vontade de um outro diferente de si mesmo. Neste sentido, acolhe a vontade daquele que, na Trindade imanente, confere-lhe a natureza divina e que se manifesta quando o Verbo encarnado, na economia salvífica, aparece como imagem do Pai, de quem lhe é consubstancial. Porém, mesmo quando o Filho renuncia a sua própria vontade para fazer a vontade do Pai, sendo-lhe obediente até a morte de cruz, tal renúncia não é ato de sua vontade singular, ou seja, não é escolha pessoal da segunda hipóstase, mas expressão da sua consubstancialidade com as outras hipóstases, haja vista que em Deus há uma só vontade que, por sua vez, é própria da natureza divina comum. Com efeito, a vontade da pessoa de Jesus Cristo, que é pessoa divina, é, por assim dizer, vontade divina. Logo, a vontade do Logos encarnado é vontade comum às Três hipóstases divinas.

É a renúncia à própria vontade para cumprir a vontade do Pai, obedecendo até a morte, até a cruz. Além disso, esta renúncia à vontade própria não é uma determinação, um ato, mas é, por assim dizer, próprio do ser das pessoas da Trindade, pois não existe senão uma única vontade que é própria à natureza comum. A vontade de Deus em Cristo, então, era a vontade comum de três: a vontade do Pai, fonte de vontade, a vontade do Filho, a obediência, a vontade do Espírito Santo, o cumprimento 529 .

Neste sentido, a obra realizada pelo Verbo encarnado é, sobretudo, obra da Santíssima Trindade, da qual não se pode separar o Cristo, que tem a mesma natureza, mas também a mesma vontade do Pai e do Espírito Santo ${ }^{530}$. Outrossim, a fidelidade de Cristo à única vontade das três hipóstases coincide com a sua

\footnotetext{
528 lbid., p.136

$529 \mathrm{lbid}$.

530 lbid., p.137.
} 
kênosis como pessoa, o que está diretamente ligado ao fato de que a encarnação do Verbo não consiste em manifestar a si mesmo, mas ser imagem de um outro além de si, que Lhe é consubstancial. Sendo assim, a kênosis não é nada mais que o modo de ser da pessoa divina enviada ao mundo. Nela cumpre-sea vontade comum da Trindade, da qual o Pai é a fonte. Os dizeres de Jesus o Pai é maior do que eu é a expressão desta renúncia kenótica à própria vontade ${ }^{531}$.

Seguindo esta linha de raciocínio Vladimir Lossky nos leva à compreensão dos termos do Concílio de Calcedônia sobre as duas naturezas "em uma só pessoa ou hipóstase: o único e mesmo Filho Unigênito de Deus, Verbo e Nosso Senhor Jesus Cristo"532. Tal linha de raciocínio destaca o elo que há entre a divindade da pessoa de Jesus Cristo e a natureza divina comum às três pessoas divinas. Todavia, os termos da definição calcedoniana, segundo a qual "deve-se confessar um só e mesmo Filho, Nosso Senhor Jesus Cristo, perfeito na divindade e perfeito na humanidade, verdadeiro Deus e verdadeiro homem (...)"533, impõenos duas questões: para o conceito de pessoa é, de fato, preciso o binômio pessoa-natureza, haja vista que não é possível que haja pessoa sem natureza e nem vice-versa? E se a pessoa de Cristo, unida indissoluvelmente à natureza divina, não é uma pessoa humana, mas sim divina, então como pode-se afirmar que Ele é perfeito na humanidade e verdadeiro homem? Lossky, na obra A noção teológica da pessoa humana, escrita três anos antes de sua morte, de maneira muito simples, porém não simplória, responde ambas as questões:

Podemos conceber a realidade da encarnação de Deus sem admitir alguma transmutação da divindade em humanidade, alguma confusão ou mistura do incriado com o criado, justamente porque distinguimos a pessoa ou a hipóstase do Filho de sua natureza ou essência: uma pessoa que não é formada de duas naturezas - ek dyo physeôn - mas que se encontra em duas naturezas - en dyo physein. A expressão "união hipostática" (não obstante a sua conveniência e o seu uso geral) é imprópria porque nos leva a pensar em uma natureza ou substância humana pré-existente à encarnação e que entraria na hipóstase do Verbo, quando na verdade, esta natureza ou substância humana assumida pelo Verbo no seio da Virgem Maria, começa a existir como esta natureza ou substância particular apenas no momento da encarnação, isto é, na unidade da pessoa ou hipóstase do Filho de Deus feito homem. Portanto, a humanidade de Cristo pela qual ele é "consubstancial a nós" jamais teve outra hipóstase senão aquela do Filho de Deus; todavia, ninguém irá negar que a sua natureza humana tenha o caráter de uma "substância individual" e o dogma de Calcedônia insiste sobre o fato de que Cristo é "perfeito na sua humanidade", "verdadeiramente homem", "(composto) de uma alma racional e de um corpo" (ek psychês logikês kai sômatos). Nestas condições o sujeito humano de Cristo tem o mesmo caráter das outras substâncias ou naturezas particulares da humanidade que chamamos "hipóstases" ou "pessoas". Se, porém, aplicássemos a ele esses títulos, cairíamos no erro nestoriano, dividindo a unidade hipostática de Cristo em dois seres "pessoais" separados. A partir do momento em que, segundo

\footnotetext{
531 lbid.

532 lbid., p.135.

533 lbid.
} 
Calcedônia, uma pessoa divina tornou-se consubstancial às pessoas criadas, esta se tornou uma hipóstase da natureza humana, sem se transformar em hipóstase ou pessoa humana. Se, portanto, Cristo é uma pessoa divina, mesmo sendo plenamente homem por natureza, se deverá admitir (ao menos no caso de Cristo) que, aqui, a hipóstase da humanidade assumida não pode ser reduzida à substância humana a este indivíduo humano que entrou no censo de Augusto junto a outros sujeitos do império romano. Mas, ao mesmo tempo, é possível dizer que Deus entrou no censo do imperador segundo a sua humanidade, justamente porque este indivíduo humano, este "átomo" da natureza humana que pôde entrar na contagem realizada pelos censores, junto aos demais, não era uma pessoa humana ${ }^{534}$.

O extenso fragmento acima citado é de capital importância para compreendermos exatamente o que Lossky entende por natureza humana, seja quanto à questão da relação entre a natureza humana e a hipóstase divina em Cristo, seja quanto à questão da relação entre as suas duas naturezas.

\subsection{1 \\ A natureza humana de Jesus Cristo}

Vladimir Lossky discorre sobre o tema da natureza humana de Cristo principalmente na obra Teologia mística da Igreja do Oriente. Aí o autor russo também se debruça sobre a relação da unidade entre a natureza humana e a natureza divina em Jesus Cristo a partir do pensamento de São João Damansceno.

Segundo São João Damasceno, que resume a doutrina cristológica dos Padres, a encarnação ocorreu pela ação do Espírito Santo, que fez a Virgem apta a receber em seu corpo a divindade do Verbo, bem como para o próprio Verbo, o qual formou da carne virginal as primícias da humanidade ${ }^{535}$.

Ao recordar o pensamento de São João Damasceno, Lossky quer declarar que o Logos ao assumir a natureza humana, também a deificou. De modo que a sua existência torna-se aí existência divinizada, pois a humanidade que a pessoa do Filho assumiu e apropriou-se recebe o seu ser somente na hipóstase divina. A humanidade não existia primeiro como natureza distinta, não entrou em união com Deus, mas aparece desde o pricípio como natureza humana do Verbo ${ }^{536}$.

Já para referir-se às características dessa natureza humana, Lossky recorre a Máximo, o Confessor, o qual afirma que a natureza humana tinha o caráter imortal e incorruptível da natureza de Adão antes do pecado, porém, Cristo a submeteu voluntariamente à condição da nossa natureza decaída. Sendo assim, Cristo teria permanecido alheio ao pecado original, mas assumido tudo aquilo que

${ }^{534}$ LOSSKIJ, V. La nozione teológica di persona umana. ApudŽAK, L. Trindade e imagem., pp.115116.

${ }^{535}$ LOSSKY, V. La teologia mística dela Chiesa d'Oriente., p.133.

536 Ibid. 
era contrário à natureza, ou seja, as consequências do pecado. Portanto, Cristo assumiu toda a realidade humana tal como ela era depois do pecado dos primeiros pais, exceto o pecado em si, assumindo, assim, uma natureza individual e pas sível de sofrimento e de morte. Em suma, devemos entender que desta maneira o Verbo desceu até os mais profundos confins do ser corrompido pelo pecado, indo até mesmo à morte e ao inferno. Sendo Deus perfeito, Ele se fez não somente homem perfeito, mas também assumiu todas as imperfeições e todas as limitações devidas ao pecado 537 .

Lossky procura desenvolver em seu pensamento uma rigorosa distinção entre pessoa e natureza. Para ele a encarnação está de fato em vista da redenção do homem. E é justamente por isso que Jesus Cristo realmente assumiu sobre si tudo aquilo que pertence à natureza humana decaída. Ora, mas cabem aqui dois questionamentos: como Cristo interveio de modo reparatório sobre aquilo que é universal, se Ele fez a experiência da natureza humana apenas em nível particular pela posse específica da natureza humana recebida da Virgem Maria? Como Cristo pode interagir com a natureza decaída, se Ele mesmo assumiu sobre si uma natureza humana deificada?

Lubomir Žak, ao comentar a cristologia de Lossky, apresenta duas direções em vista das soluções para os dois questionamentos apresentados acima. A primeira solução, chamada por Žak de cosmológica, recorda a ideia da misteriosa presença dos logoi no mundo criado a partir do Logos eterno e, por isso mesmo, a Ele relacionado, o qual, por sua vez, está também misteriosamente relacionado com a realidade do homem feito à imagem e semelhança de Deus. Žak recorda que de acordo com alguns Padres da lgreja, tal presença não foi nem mesmo prejudicada pelo pecado original. O próprio Máximo, o Confessor, procurou inserir na cristologia a ideia de um mundo como uma realidade complexa, de infinitos planos, porém todos unidos e em comunicação por meio de uma rede metafísica composta pelos logoi. Eis a estrutura metafísica da realidade criada, segundo Máximo:

(...) os logoi de todas as coisas divididas e parciais estão contidos nos logoi das coisas totais e gerais, como dizem, e os logoi das coisas mais gerais e mais totais são mantidos juntos pela sabedoria, ao passo que aqueles das coisas parciais, de vários modos mantidos no âmbito dos logoi das coisas gerais, são abraçados pela prudência (...). Mas a sabedoria e a prudência são o Senhor Jesus Cristo, quem mantém unido o universo na potência de sua sabedoria e abraça as partes que o completam com a prudência de sua inteligência, uma vez que é por natureza o criador de tudo e a tudo provê, conduzindo à unidade todas as coisas que estão separadas, extinguindo a guerra que nelas existe e unindo em uma amizade pacífica

537 Ibid., p.134. 
e em uma indissolúvel concórdia, como diz o divino apóstolo, aquelas que estão nos céus e sobre a terra ${ }^{538}$.

É nesta perspectiva de Máximo, o Confessor que Lossky compreende a verdadeira posse que Cristo possui de toda realidade que pertence à comum natureza humana decaída pelo pecado original, assim como a ideia sobre a possibilidade de uma ligação real entre Cristo e a natureza comum corrompida.

A segunda solução apontada por Lubomir Žak para os dois questionamentos anteriormente mencionados, versa sobre a reflexão a respeito do status da natureza humana de Cristo recebida da Virgem Maria. Žak afirma que para Lossky tal natureza é de fato uma natureza deificada. Contudo, considerando o que já expomos, deve-se deduzir que ele entende por natureza deificada não apenas o resultado final, mas uma realidade "sempre em ato".

\begin{abstract}
Realidade - entende-se - que não pode ser compreendida segundo uma lógica de crescimento ou de incremento, como se o seu status de natureza divinizada consistisse no caminhar para uma deificação sempre mais perfeita; em resumo: como se a humanidade de Jesus Cristo não fosse, desde o início, permeada inteira e completamente pela divindade. Tal misteriosa realidade, ao contrário, deve ser vista como um acontecer sempre novo e realizado, como um constante e sempre completo revestimento da natureza humana na divindade, no sentido das palavras de Máximo, o Confessor: "(...) nenhuma realidade criada jamais parou em seu movimento e, muito menos, cessou o seu movimento conforme o seu fim, que é Deus" 539 .
\end{abstract}

Tal raciocínio cristológico em nível ontológico gera consequências mariológicas. Pois parece admitir que a Virgem Maria, ontologicamente poderia pecar ou, pelo menos, ter sentido em si a vontade da comum natureza humana decaída, o que evidentemente seria contrário ao dogma católico da Imaculada Conceição. Porém, como é sabido, os ortodoxos não aceitam o referido dogma exatamente porque crêem que o fato de Maria nunca ter pecado, é, com efeito, um evento da graça da qual ela é plena por sua constante e total adesão à vontade de Deus. Neste sentido, a compreensão de Lossky a respeito da natureza deificada é verdadeiramente uma resposta ao problema da interação salvífica de Cristo com a comum natureza humana decaída.

\title{
6.3.2
}

\section{A divina humanidade de Jesus}

Quando falamos em divina humanidade de Jesus, subentende-se a relação das duas naturezas na única pessoa ou hipóstase de Cristo. Do que vimos

\footnotetext{
538 MASSIMO IL CONFESSORE. Ambigua. Apud ŽAK, L. Trindade e imagem., pp.119-120.

539 ŽAK, L. Trindade e imagem., pp.121-122.
} 
até aqui do pensamento de Vladimir Lossky, pudemos perceber a seguinte dualidade presente em sua cristologia: de um lado a relação entre hipóstase divina e natureza divina, que tem sempre por referência o mistério da Trindade; e de outro lado a relação dinâmica entre Logos encarnado e a natureza humana, relação dinâmica porque compreendida como evento de uma deificação sempre em ato. Tais reflexões agora convergem para a busca de uma síntese dogmática do que seja a coexistência entre as duas naturezas em Cristo.

Posto isto, devemos recordar que Lossky é extremamente fiel à cristologia do Concílio de Calcedônia quando sublinha "que as duas naturezas de Cristo permanecerão distintas, não misturadas uma com a outra"540. Concomitantemente, o teólogo russo não deixa de recorrer a Máximo, o Confessor quando afirma que as duas naturezas entram em uma certa interpenetração (perichóresis eis alléas) $^{541}$. Aí temos, no âmbito do dogma cristológico, a concepção oriental das energias, como processões da natureza.

Esta interpenetração das naturezas a que chamam os orientais de pericórese consiste no mútuo envolvimento das duas naturezas, entendido sob a ótica da teoria das energias divinas. Lossky, em A teologia mística da Igreja do oriente, não se mostra muito disposto a se aprofundar no tema. Contudo, apresenta-nos a explicação de João Damasceno sobre a pericórese, afirmando que ela tem a iniciativa da divindade e não da carne, e que "uma vez penetrada a carne, a divindade lhe dá uma faculdade inefável de penetrar na divindade" ${ }^{42}$. Em seguida, Lossky continua a explicar que a humanidade deificada de Cristo está penetrada pelas energias divinas em seu ser; daí ele recorre a Máximo, o Confessor referindo-se a sua imagem da união entre o ferro de uma espada e o fogo para explicar a união das duas naturezas em Cristo, segundo a qual, da mesma formaque o ferro penetrado pelo fogo torna-se fogo, ainda que permaneça ferro por natureza, assim a natureza humana de Cristo está em conexão com as energias divinas. Com efeito, em cada agir de Cristo são visíveis duas operações distintas.

Em cada ato de Cristo são visíveis duas operações distintas, porque o Cristo age conforme as duas naturezas, por meio das duas naturezas; como a espada em brasa corta e queima ao mesmo tempo: ela corta como ferro e queima como fogo. Cada natureza age segundo sua propriedade: a mão humana levanta a menina, a divindade a ressuscita; o pé humano caminha sobre a superfície da água, porque a divindade os sustenta ${ }^{543}$.

\footnotetext{
${ }^{540}$ LOSSKY, V. La teologia mística dela Chiesa d'Oriente., p.137.

541 lbid.

542 lbid.

543 lbid., p.138.
} 
Para Lossky a relação entre a natureza divina e a natureza humana em Cristo é uma relação dinâmica, isto é, em movimento, visto que ambas as naturezas já são realidades dinâmicas em si. No caso da natureza divina, na ordem intradivina, vem conferida às hipóstases do Filho e do Espírito Santo pela hipóstase do Pai (esta atribuição trata-se de um ato de processão eterna), ao passo que na ordem da economia de Deus, a mesma natureza se manifesta no mundo por meio das suas duas imagens divinas, ou seja, o Lógos e o Espírito Santo. Já no caso da natureza ou essência humana, esta também está em movimento como realidade universalmente humana. Contudo, por se tratar de uma natureza criada, o seu movimento é determinado pela manifestação, por parte da pessoa humana, daquilo que o homem é desde o princípio como ser feito à imagem e semelhança de Deus. Esse movimento é a própria deificação. $E$ ambos os movimentos estão ligados, na ordem da Trindade econômica, ao evento da representação. Mas a questão não está resolvida, por assim dizer. É importante saber o que as duas naturezas possuem em comum no plano da dinâmica manifestação e, principalmente, saber como estes movimentos coexistem no Cristo, pessoa divino-humana ${ }^{544}$.

Lossky não se aprofunda muito nesta questão, talvez isso possa ser considerado por alguns como um enfraquecimento para a sua cristologia, como o pensa Žak. Contudo, longe de ser simplório, Lossky faz de fato um corte epistemológico na investigação da questão, delimitando seu estudo à relação entre as duas vontades de Cristo, concebida em sintonia com a teologia de Máximo, o Confessor, e de João Damasceno. Embora Sergei Bulgakov, outro grande teólogo ortodoxo, já tivesse criticado Máximo, o Confessor, precisamente por causa da sua teoria das duas vontades em Cristo; mais exatamente ainda por ter posto a vontade como um novo conceito ao lado do conceito de energia, ou operação, sem, contudo ter esclarecido o real significado de vontade.

\begin{abstract}
Avaliando, portanto, a contribuição de São Máximo à doutrina das duas vontades, com todo o respeito pelo seu forte empenho na defesa da tese ortodoxa a respeito das duas vontades e energias em Cristo, não podemos, contudo, dizer que nele encontramos a este propósito uma sólida doutrina teológica, sobretudo em relação às questões mais importantes sobre como as duas vontades em Cristo possam agir contemporaneamente. Nele o futuro dogma é afirmado, porém não está teologicamente amadurecido, tanto que ele mesmo não se mostra nem equilibrado e nem coerente na sua aplicação. ${ }^{545}$
\end{abstract}

\footnotetext{
544 ŽAK, L. Trindade e imagem., pp.124-125.

545 BULGAKOV, S. N. L'Agnello di Dio., p.135. Pela expressão "futuro dogma" Bulgakovse refere à definição das duas vontades e das duas energias, ou operações, formulada pelo Concílio de Constantinopla III.
} 
Mas passemos agora à explicação de Lossky quanto à relação das duas naturezas em Cristo. Sua explicação, com efeito, consiste em uma síntese significativa da doutrina de Máximo, o Confessor, e de João Damasceno. Ele afirma que as duas vontades, próprias às duas naturezas, são diferentes. Porém, Aquele que quer é uno, embora queira em conformidade com cada uma das duas naturezas. Uno é também o objeto da volição, pois as duas vontades estão unidas, estando a vontade humana livremente submetida à vontade divina ${ }^{546}$.

Neste sentido, a relação entre as duas vontades está fundada na postura de livre submissão da vontade humana à vontade divina. Aí, então, entramos em outro conceito: o conceito de liberdade da natureza humana para Lossky. Ele, como já era de se esperar, segue a concepção de Máximo, apesar de conhecer a crítica de Bulgakov, que rechaça a compreenção do referido Padre Grego por reservar à humanidade de Cristo somente uma vontade natural, instintiva, linear, infalível, quer dizer, uma vontade que não é guiada pelos juízos da razão, a chamada vontade gnômica ${ }^{547}$. Tanto Lossky, quanto São Máximo, afirmam que a liberdade da natureza humana de Cristo de fato não tem nada a ver com a gnóme

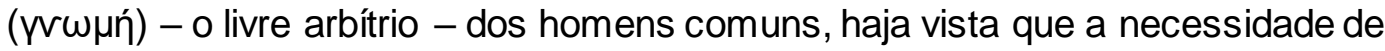
escolher é própria da pessoa humana, cuja liberdade se encontra prejudicada, e até mesmo diminuida, pela condição de uma natureza ferida pelo pecado dos primeiros pais. Portanto, a pessoa divina do Verbo não possuía necessidade de escolher e nem de deliberar sua decisão ${ }^{548}$.

Como temos visto, Lossky é fortemente influenciado pela teologia de Máximo, o Confessor, de modo que essa sua percepção acima exposta, é melhor compreendida a partir do conceito de gnóme verificado em Máximo. Este, antes de tudo, distingue "vontade natural" de "vontade gnômica". A natureza humana, fruto do ato criativo de Deus, continuamente põe em xeque suas propriedades dinâmicas, que por sua vez juntas constituem a "vontade natural", ou seja, um dinamismo criado por Deus, Contudo, quando a pessoa - ou hipóstase - humana abusa de sua liberdade rebelando-se contra Deus e contra a natureza, pode distorcer a "vontade natural" e, assim, corromper a própria natureza. E pode comportar-se deste modo porque tem livre arbítrio para isso, ou "vontade gnômica", a qual é capaz de orientar o homem em direção ao bem e à imitação de Deus. Para Máximo só Deus é bom por natureza, e só o que imita Deus é bom por sua gnóme, malgrado o homem também ser capaz de cometer pecado, pois

\footnotetext{
546 LOSSKY, V. La teologia mística dela Chiesa d'Oriente., p.138.

547 BULGAKOV, S. N. Op. cit., p.132.

548 LOSSKY, V. Op. cit.
} 
sua salvação depende de sua vontade. Todavia, o pecado é sempre um ato da pessoa, não da natureza ${ }^{549}$. Neste sentido, Máximo não adimite que a gnóme pertença à natureza humana de Cristo. Pois, diferentemente dos seres humanos comuns, em Cristo há uma perfeita realização hipostática da pessoa, realização à qual todo homem é chamado por graça. Por conseguinte, esta consiste na cura da gnóme humana, vivida como imitação de Deus, ou como conformação da "vontade gnômica" à norma da "vontade divina". Em suma, a cura da gnóme consiste no retorno à natureza e ao mistério do seu próprio ser feito à imagem e semelhança de Deus. Ao contrário, Cristo, por sua dúplice consubstancialidade, "pode viver e conservar em si o mistério da dupla identidade icônica: o mistério de seu ab eterno, imagem da comum natureza divina; e o mistério do ser "feito à imagem e semelhança" por Ele participado mediante a sua natureza humana"550.

Assim, Lossky compreende a subordinação da natureza humana à natureza divina em Cristo, como subordinação da vontade humana, ou vontade natural à vontade divina e, evidentemente, à pessoa divina. Para ele, a humanidade de Cristo poderia querer humanamente, mas a sua pessoa divina não exercitava o livre-arbítrio como os seres humanos comuns. Conforme o pensamento de São João Damasceno, Lossky entende que a vontade divina permitia à vontade humana querer e manifestar plenamente tudo aquilo que é próprio da humanidade. De modo que a vontade divina precedia a vontade humana, assim, o querer de Cristo é um querer divino, ou seja, em conformidade com a divindade que lhe permitia exprimir-se. Neste sentido, as duas vontades naturais jamais poderiam entrar em conflito na pessoa do Deus-Homem ${ }^{551}$.

Lossky percebe que até os momentos mais difíceis da vida de Jesus devem ser interpretados à luz deste pensamento acima exposto. É o caso da oração no Getsêmani; momentos como este representam uma situação limite, em que a vontade humana não deixou de se realizar, contudo, conforme a medida divina. Aí a hipóstase do Lógos encarnado pôde se manifestar por aquilo que era, ou seja,

\footnotetext{
549 MEYENDORFF, J. Teología Bizantina., pp.266-274. A tradição ortodoxa, em sua antropologia, com preende o pecado como sendo sempre um ato da pessoa, não da natureza. De modo que alguns Padres gregos, em referência à teologia ocidental, chegam até mesmo a afirmar que a crença em um "pecado de natureza" é heresia. Deste pensamento básico do caráter pessoal do pecado, entende-se que o pecado dos primeiros pais trata-se de um pecado pessoal. Com efeito, nesta antropologia é rechaçada qualquer ideia de culpabilidade hereditária, ou de "pecado de natureza", apesar de se admitir que a natureza humana incorre nas consequências do pecado dos primeiros pais. São Máximo, o Confessor, quando trata das conse quências do pecado de Adão, as identifica, antes de tudo, com a submissão da mente aos ditados da carne e percebe na processão sexual o sinal mais claro da conformidade do homem com os instintos animais. Para ele, assim como para outros Padres gregos, a escolha de Adão introduziu a paixão, a corrupção e a mortalidade, mas não uma culpabilidade herdada.

550 ŽAK, L. Trindade e imagem., p.128.

551 LOSSKY, V. La teologia mística dela Chiesa d'Oriente., p.139.
} 
a imagem da natureza divina, mas por meio de sua natureza humana. Entretanto, a sua natureza humana, mesmo deificada, era plenamente na medida do homem, o que naturalmente explica a vontade humana de não se submeter à paixão e morte, que o levou a rezar para ser poupado.

A oração do Getsêmani era uma expressão de horror diante da morte, reação própria de toda natureza humana, acima de uma natureza incorruptível que não deveria sofrer a morte, assim também a morte só poderia ser uma laceração voluntária, contrária a natureza. "Quando a sua vontade humana - diz São João Damasceno - se refutava em aceitar a morte e a sua vontade divina dava logo a esta a manifestação da humanidade, em seguida o Senhor, conforme a sua natureza humana, na luta e no temor, orava para ser poupado da morte. Mas porque a sua vontade divina queria que a vontade humana aceitasse a morte, o sofrimento tornou-se voluntário para a humanidade de Cristo". Também o último grito de angústia mortal de Cristo sobre a cruz era uma manifestação da sua verdadeira humanidade, que sofreu voluntariamente a morte como despojamento final, como o fim da kénosis ${ }^{552}$.

Essa subordinação da vontade humana à vontade divina é a base sobre a qual se estabelece a relação entre as duas vontades. Lossky traduz esta dinâmica relacional através da kénosis, no entanto, não no sentido mais estrito presente em Filipenses 2, 7, mas em um sentido mais amplo e aprofundado. O teólogo russo entende por kénosis não somente a catábase do Verbo que assumiu a nossa humanidade na condição de servo, mas também a submissão voluntária da natureza humana deificada de Cristo a todas as consequências do pecado; submissão que, por sua vez, introduzia na sua pessoa divina toda a falência da natureza humana devastada pelo pecado. Em suma, para Lossky a kénosis de Cristo consistia na humilhação contínua do Deus-Homem, de modo que a sua vontade humana renunciava também continuamente àquilo que lhe era próprio por natureza e aceitava aquilo que era contrário à humanidade incorruptível e deificada.

É em virtude deste abaixamento que Cristo, novo Adão, incorruptível e imortal segundo a natureza humana - natureza que era também deificada pela união hipostática - se submeteu voluntariamente à toda consequência do pecado, tornou se o "homem das dores" de Isaías $(53,3)$. Ele introduziu, assim, na sua pessoa divina a falha da natureza humana devastada pelo pecado, assimilando a realidade histórica na qual a encarnação deveria ter lugar. Por isso, a vida terrena de Cristo foi um abaixamento contínuo: a sua vontade humana renunciava incessantemente ao que Ele era próprio por natureza e aceitava o que era contrário à humanidade incorruptível e deificada: a fome, a sede, o cansaço, a dor, o sofrimento e, enfim, a morte na cruz. Assim, pode-se dizer que a pessoa de Cristo, antes do fim da obra da redenção e antes da ressurreição, tinha em sua humanidade como que dois pólos diversos: a incorruptibilidade e a impassibilidade naturais, próprias de uma natureza perfeita e deificada e, ao mesmo tempo, a corruptibilidade e a passibilidade

552 lbid. 
voluntariamente assumidas, condições às quais a sua pessoa kenótica submeteu e submetia a sua humanidade live do pecado ${ }^{553}$.

Ao estabelecer esta distinção de dois pólos, Lossky coloca a natureza humana de Cristo na condição de kénosis voluntária e segue a teoria de São Máximo a respeito da divisão da humanidade do Lógos gerado e encarnado. São Máximo, o Confessor, de fato, ao abordar os tipos de gerações, percebe que Cristo não se negou a ser gerado por causa da transgressão do primeiro homem e que, desse modo, mostrou com o nascimento a sua complacência para com o ser humano que havia caído e, com a geração, a sua voluntária kénosis em favor daquele que fora condenado ${ }^{554}$.

Sendo assim, em Cristo existem, exatamente por causa do seu nascimento como homem, dois tipos de experiência da natureza humana: por um lado Cristo através do nascimento identifica-se com o homem por natureza e assim recebe 0 "ser imagem e semelhança", porém, continuando a conservar inegociável a liberdade, mas também íntegra a impossibilidade de pecar, e por outro lado, com a geração na carne se submeteu, de bom grado, à semelhança com o homem da corrupção a partir da forma de servo e se submeteu voluntariamente como nós às paixões, porém não ao pecado 555 .

Para São Máximo, o Confessor, a humanidade de Cristo é composta de duas partes porque há em Cristo a parte relativa à condição de um novo Adão, mas também há a parte relativa à condição do primeiro Adão não diminuído. Cristo conseguiu unir em torno de si essas duas partes e com a sua grande potência sanou ambas, eliminando as extremidades ${ }^{556}$ próprias de cada uma e tornando a segunda - que é desprezível por causa de sua passionalidade - salvadora e renovadora da primeira - que é preciosa -, e a primeira, reforçadora e protetora da segunda.

Por fim, Lossky, como um bom teólogo ortodoxo não deixa de apelar à Transfiguração do Senhor como um dos eventos chave para a compreenção da humanidade de Cristo na tradição oriental. Ele afirma que a Transfiguração é a manifestação da realidade daquilo que Cristo é ontologicamente como Logos divino ao mesmo tempo em que coincide com o misterioso evento de divinização de sua natureza humana submetida às consequências do pecado. $E$ isso é muito

\footnotetext{
553 lbid., p.140.

${ }^{554}$ MASSIMO IL CONFESSORE, Ambiguum 42, 466 Apud ŽAK, L. Trindade e imagem., p.130. 555 lbid.

556 Por "extremidade" Máximo entende, de um lado, a incorruptibilidade do primeiro nascimento (precioso), como princípio da impossibilidade de pecar, e, de outro, a possibilidade de pecar, própria da segunda geração (desprezível), visto que é a causa de cada paixão e corrupção. Cf. ZAK, L. Op.cit.
} 
bem destacado no cântico da Festa da Transfiguração, quando se diz: "Tu Te transfigurastes sobre o monte, ó Cristo Deus, e a glória envolveu de admiração os Teus discípulos, de modo que ao vê-lo crucificado compreendem como o sofrimento é voluntário e anunciam que tu realmente és o Esplendor do Pai”557. É, com efeito, neste sentido que pode-se compreender a natureza humana de Cristo como realidade dinâmica, em movimento, que faz aparecer a natureza divina, porém, como esplendor comum de todas as três hipóstases.

\begin{abstract}
A humanidade de Cristo servirá de ocasião para a manifestação da Trindade; a Epifania (Festa do Batismo de Cristo, segundo a tradição litúrgica do Oriente) e a Transfiguração serão, portanto, celebradas de modo solene: se celebrará a revelação da Trindade, porque a voz do Pai se faz entender e o Espírito Santo se faz presente pela primeira vez no aspecto de uma pomba, a segunda vez foi na nuvem luminosa que cobriu os apóstolos ${ }^{558}$.
\end{abstract}

É a partir desta chave de compreenção visualizada nas orações litúrgicas que também se pode interpretar a paixão e a morte de Cristo. Ele vivenciou estes eventos com o aspecto de sua realeza, ou seja, como um da Trindade. Nele, apesar de toda ignomínia, transparecia a dignidade de um Rei universal que virá para julgar o mundo, como o Criador do cosmos em meio à criação tomada pelo medo do mistério da cruz. E, por fim, no seu repouso no sepulcro, imagem máxima da kénosis divina, aparece o repouso misterioso do Criador; é aí que a obra da redenção identifica-se com a obra da criação ${ }^{559}$.

O aspecto régio de Cristo - um da Santíssima Trindade - que vem ao mundo para vencer a morte e livrar os prisioneiros, é característico da espiritualidade ortodoxa de todas as épocas e de todos os países. Tanto a paixão, quanto a morte na cruz e a descida ao sepulcro terão um caráter triunfal onde a majestade de Cristo faz o mistério de nossa salvação transparecer através da imagem da derrota e do abandono ${ }^{560}$.

\footnotetext{
${ }^{557}$ LOSSKY, V. La teologia mística dela Chiesa d'Oriente., pp.140-141.

558 Ibid., p.141.

559 lbid., p.142.

560 lbid.
} 


\section{7 \\ Epílogo}

O Concilio de Calcedônia legou à lgreja uma consistente e equilibrada Fórmula Dogmática que confessa a plena divindade e a plena humanidade de Cristo, unidas na sua Pessoa divina. Assim, a Fórmula de Calcedônia constitui a "grande" fórmula cristológica da lgreja. Equilibrada e sintética, ela é definitiva no sentido em que permanece como pedra angular da expressão eclesial da fé em Jesus Cristo, e toda reflexão cristológica deve se situar em relação a ela. E ainda, mais do que nunca a fórmula calcedoniana é fórmula de referência para o ecumenismo no conjunto das lgrejas, exceto aquelas denominadas de "précalcedonianas". Ela é dotada de notável autoridade e conserva sua atualidade precisamente por ser um verdadeiro guia de leitura cristã dos textos da Sagrada Escritura, e até mesmo um critério de discernimento teológico que se estende para além da cristologia propriamente dita ${ }^{561}$.

Todavia, a Fórmula Dogmática de Calcedônia, segundo o pensamento de Rahner no ensaio Chalcédoine une fin ou un commencement ${ }^{562}$, foi tanto um ponto de partida como um ponto de chegada. Como a própria história atestará, ela não esgotou o debate cristológico, mas foi o marco de um progresso que abriu caminho para outros progressos, permanecendo, porém, inacabada. Contemporaneamente, ela é ocasião para um debate teológico vigoroso que, ainda que sob críticas, reconhecemos nela o enunciado dos critérios que devem ser absolutamente respeitados por toda teoria cristológica ${ }^{563}$.

A fórmula dogmática do Concílio de Calcedônia quis salvaguardar a plena humanidade de Cristo, mantida em sua originalidade criada a partir da encarnação. Contudo, ao defender a plena humanidade do Verbo eterno de Deus, ela defende também a nossa, e isso é o que defende a Constituição Pastoral Gaudium et Spes ${ }^{564}$ do concilio Vaticano II. Tal inaudita proximidade de Deus constitui a mais alta e perfeita elevação da dignidade humana.

\footnotetext{
561 SESBOÜÉ, B. Jésus-Christ dans la tradition de l'Eglise., pp.195-205.

562 RAHNER, K. Chalcédoine une fin ou um commencement? Apud SESBOÜÉ, B. História dos Dogmas., p.350.

563 PANNENBERG, W. Esquisse d'une christologie. Apud SESBOÜÉ, B. Op. cit.

564 GS, 22,2.
} 
Porém, a fórmula calcedoniana traz ainda consigo um risco: pensar as duas naturezas como realidades situadas numa espécie de "lado a lado" ou de "parelha", como se fossem realidades comparáveis, quando, na verdade, a diferença entre natureza divina e natureza humana é incomensurável. Neste sentido, qualquer comparação entre ambas as realidades seria no mínimo equivocada. Muitos autores da época costumavam representar a união das duas naturezas de Cristo em sua única pessoa utilizando a imagem do ferro incandescido, porém a mais corrente era a da alma e do corpo. Com efeito, da mesma forma que a alma e o corpo são dois princípios heterogêneos que unidos formam um indivíduo único, sem se misturarem, mas conservando suas respectivas propriedades; assim também as naturezas divina e humana não se misturam, mas se unem para formar o único Senhor Jesus Cristo. Se bem que esta analogia necessita ser corrigida, visto que ela não pretende aplicar a concepção aristotélica da alma como forma do corpo no caso da união hipostática.

A Fórmula de Calcedônia trata da encarnação do Verbo eterno de Deus sem, contudo, fazer menção ao mistério pascal. Evidentemente, vivendo a kenosis, a relação da divindade e da humanidade de Jesus não é vivida da mesma forma antes e depois da ressurreição. Porém, a fórmula não leva em consideração o itinerário humano de Jesus e os dados "existenciais" da encarnação ${ }^{565}$.

Outrossim, a fórmula não é capaz de dar uma definição clara dos termos empregados. Ela deixa em aberto certas questões que dão margem a compreensões divergentes a respeito daquilo que é necessário situar sob os termos hipóstase e natureza ${ }^{566}$.

Com efeito, diante de todos os questionamentos levantados em relação à cristologia clássica e das propostas feitas em vista de uma abordagem renovada da cristologia calcedoniana, somos levados a concluir que os teólogos católicos, protestantes e ortodoxos, sobre cujos esboços cristológicos temos discorrido até o presente momento, lançam luzes sobre as sombras em que jaz a cristologia tradicional, uma vez que trilham novos caminhos a fim de encontrar respostas aos questionamentos do homem contemporâneo. Neste epílogo, cabe-nos ressaltar a pertinência de alguns aspectos apontados pelos autores abordados, em vista de uma leitura atualizada da Fórmula de Calcedônia, bem como as implicações ecumênicas e pastorais desta compreensão renovada do dogma calcedoniano.

Antes de tudo é preciso reconhecer que os questionamentos suscitados nas últimas seis décadas a respeito da fórmula dogmática de Calcedônia são frutos

${ }^{565}$ SESBOÜÉ, B. História dos Dogmas., p.351.
566 lbid. 
do renovado interesse pela cristologia, surgido antes mesmo do Concílio Vaticano II, junto aos movimentos bíblico e patrístico. O referido interesse pela fórmula calcedoniana tem despertado tantos julgamentos positivos, quanto sérios questionamentos sobre a validade atual da mesma fórmula, principalmente no que diz respeito às expressões ontológicas.

Atualmente se concebe que o ponto de partida do movimento cristológico foi de fato a celebração dos 1500 anos do Concílio de Calcedônia em 1951. O próprio Papa Pio XII escreveu a encíclica Sempiternus Rex marcando assim as comemorações deste $15^{\circ}$ centenário do concílio. A partir daí importantes textos foram produzidos em relação com o tema.

\section{1 Novos caminhos para o estudo do Jesus Histórico}

Em nossa abordagem não tratamos da questão do Jesus histórico. Contudo, não podemos deixar de reconhecer que este renovado interesse pela cristologia deve-se em parte ao redescobrimento do Jesus histórico a partir do renascimento dos estudos bíblicos e descobrimento de novas fontes que levam à contextualização histórica e cultural da pessoa Jesus de Nazaré, além da influência das ciências modernas. Estes aspectos conduziram a uma nova visão, segundo a qual a cristologia contemporânea não pode mais pautar-se unicamente sobre a confissão de fé das definições conciliares, simplesmente considerada como adquirida. Hoje a cristologia há que fundamentar-se na história e no destino de Jesus.

Entretanto, essas novas ferramentas teológicas têm servido muitas vezes para estabelecer uma rotura entre o Jesus histórico e o Cristo da fé. Assim como muitas vezes se estabelece uma cisão radical entre as diversas cristologias do Novo Testamento (principalmente ascendente $X$ descendente), diminuindo qualquer consideração de complementaridade recíproca que estas possuem em seu interior e na totalidade do corpo do Novo Testamento. Com efeito, é preciso admitir que da mesma forma que o redescobrimento do Jesus histórico lançou luz sobre o renascimento da cristologia, uma abordagem atualizada da fórmula de Calcedônia, principalmente que parta da relação única de Jesus com o Pai, vem propor ao estudo do Jesus histórico uma abordagem articulada com as definições conciliares, uma vez que tanto a cristologia atual quanto o tema Jesus histórico têm por fonte primeira os textos neotestamentários. Uma parceria neste nível só 
vem a somar e diminuir, senão corrigir, roturas que muitos estabelecem entre o Jesus histórico e o Cristo da fé.

\section{2}

\section{Alguns aspectos a considerar}

Precisamente sobre a pertinência de alguns aspectos suscitados pelos autores, devemos entender que uma cristologia renovada que tenha como ponto de partida o dado fundante do Novo Testamento faz do Concílio de Calcedônia uma interpretação reguladora e normativa no momento de interpretar o dado bíblico, de modo que não é apropriado considerá-lo uma referência absoluta para a cristologia. Ora, tal valorização do texto neotestamentário ao ponto de tê-lo como dado fundante da cristologia, consequentemente nos leva a redescobrir uma pluralidade de abordagens cristológicas, ou seja, movimentos internos das diversas cristologias que existem no Novo Testamento, em que nenhuma é por si só absoluta ou autônoma, mas cada uma tem necessidade da relação complementar com as demais. Logo, o mistério da encarnação, visto como mistério pleno de Cristo que encontra o seu ponto mais alto na ressurreição como momento iluminador de todo o mistério de Cristo, faz da cristologia uma exposição mais articulada com o Novo Testamento, de maneira que nele encontramos a relação ímpar de Jesus com o Pai, bem como a manifestação concreta de sua consciência divina, em cujo mérito não adentramos neste ensaio.

Por outro lado, torna-se também mister fazer justiça ao Concilio de Calcedônia a partir de uma equilibrada hermenêutica conciliar, reconhecendo que algumas das críticas que têm sido feitas ao dogma calcedoniano, são consequência de posturas que enfatizam alguns aspectos, sem considerar outros igualmente importantes e até mesmo imprescindíveis, como por exemplo o fato de acusar Calcedônia de não ter contemplado todos os aspectos da cristologia, partindo de uma pré-compreenção do concílio como se fosse, ou quisesse ser, uma síntese do mistério de Jesus, quando a verdadeira intenção do concílio não era fazer síntese cristológica ou ainda um tratado completo de cristologia, mas sim fazer frente ao nestorianismo e monofisismo eutiquiano da época, salvaguardando a completa realidade divina e humana em Jesus Cristo.

Há quem acuse a fórmula calcedoniana de priorizar a cristologia "do alto", sem levar em consideração a evolução cristológica presente nos evangelhos sinóticos. Mas o ambiente teológico em que foi celebrado o sagrado concílio de Calcedônia partia da perspectiva "do alto", e a síntese proposta pelo Concílio 
seguiu a mesma direção. É verdade que há quem diga que desta maneira, a Fórmula de Calcedônia dificultaria a compreensão da kénosis ${ }^{567}$. Porém, como vimos entre os ortodoxos, o conceito de kénosis vem exatamente ao encontro da definição de 451 e a torna mais clara.

Outro questionamento que também se ergue é aquele relativo à encarnação, tal qual a fórmula calcedoniana a professa, alegando-se que atinge somente Jesus de Nazaré e não todo o gênero humano, verificando-se, portanto uma ausência de perspectiva universal e cósmica ${ }^{568}$. Contudo, tal ausência já é verificada nos Padres Gregos e Latinos, e se não foi contemplada pela fórmula calcedoniana é porque não havia esse enfoque naquele dado momento histórico e teológico.

Outra observação que de quando em vez surge é a de que a Fórmula de Calcedônia adota um esquema dualista que prejudicaria a compreensão da unidade de Cristo ${ }^{569}$. Trata-se de um questionamento pertinente, que remete à parcela de verdade dos alexandrinos, contudo a Fórmula de Calcedônia expressa com consistência e clareza suficientes a unidade da pessoa de Cristo e suas naturezas unidas na sua Pessoa divina. Calcedônia não somente afirma como também salvaguarda a integridade da natureza humana comprometida pelo monofisimo eutiquiano. Sendo assim, o Concílio de Calcedônia confessou a realidade e a perfeição da humanidade assumida em Cristo, de modo que a encarnação não anula a humanidade assumida pelo Verbo, mas a confirma e a promove. A partir da expressão "em duas naturezas" o Concílio foca sobre a verdade da natureza humana que pode estar em absoluta proximidade com Deus, de maneira que a humanidade não é diminuída, mas elevada ${ }^{570}$. Além do mais, Deus não é um ente que se pode por em paralelo com o homem, pois é aquele que transcende todos os entes ${ }^{571}$. Trata-se de uma contradição necessária para expressar o paradoxo da coexistência de divindade e humanidade em Jesus de Nazaré, a quem confessamos plenamente Deus e plenamente homem.

Outrossim o Concílio de Calcedônia tem sido acusado de helenizar o kerigma do Novo Testamento com os seus conceitos ontológicos de origem helênica. Contudo, o contexto, as personagens-chave e a mentalidade em que o concílio foi celebrado eram de fato helênicos, ou seja, há sim que se considerar os condicionamentos culturais e intelectuais da época. De modo que um questionamento neste nível corre fortemente o risco do anacronismo. Diga-se o

\footnotetext{
${ }^{567}$ BOFF, L. Jesus Cristo Libertador., p.209.

568 Jon Sobrino é um dos principais expoentes deste questionamento.

569 AMATO, A. Gesú il Signore., p.300.

$570 \mathrm{lbid}$., p.300s.

571 BOFF, L. Op.cit., p.209.
} 
mesmo em relação aos conceitos-chave de physis, ousía, prosopon e hypostasis, que não podem ser considerados atualmente como inadequados a partir das balizas de nossas perspectivas intelectuais, sem ter presente a evolução que estes conceitos sofreram ao longo dos séculos, antes de tudo como categorias filosóficas. Foi o que bem nos mostrou a cristologia ortodoxa, que ainda hoje utiliza estes conceitos sem constrangimentos, precisamente por sua compreensão renovada a respeito dos mesmos e por sua visão mais holística do saber, visão que está mais próxima da dinâmica teológica dos Padres da Igreja. Inclusive, há que se levar em conta que para um justo entendimento da cristologia de Calcedônia, é absolutamente imprescindível um mínimo conhecimento dos Padres da lgreja, bem como das problemáticas que rodeavam sua abordagem teológica (como nos mostrou Gavrilyuk). Pois um princípio geral que tem sido bastante esquecido é esta visão holística da teologia que possuíam os Padres, que não concebiam como tratados diferenciados aquilo que hoje chamamos de cristologia, antropologia, soteriologia, eclesiologia, escatologia, sacramentologia, etc.

Malgrado todos os questionamentos, a cristologia calcedoniana continua a ser uma válida expressão do kerigma neotestamentário de que Jesus Cristo é plenamente Deus e plenamente homem, e que humanidade e divindade estão unidas na sua pessoa divina, sem comprometer a suas propriedades. Contudo, todos os questionamentos feitos nos colocam diante do difícil problema da hermenêutica conciliar.

Com efeito, um concílio fornece um decreto, ou seja, uma sentença de interpretação da fé e do texto fundante que é a Escritura. A Fórmula de Calcedônia é fruto de uma assembleia eclesial legitima, elaborada em um tempo de crise quando elementos de máxima importância da fé estavam ameaçados. $O$ ato de um Concílio é um documento que não se acrescenta ao plano do texto escriturístico, mas que o interpreta e o atualiza em uma situação nova. Tal ato se inscreve em uma série de atos similares que o precedem e o seguem, e constituem uma cadeia viva de interpretações da Escritura na história da Igreja. Portanto, uma fórmula dogmática deve, então, ser sempre entendida como uma conclusão interpretativa que se refere para além dela, de forma que ela não é um ponto de partida absoluto na reflexão da fé, mas lido à luz da Escritura, como se disse, da qual qualquer fórmula quer ser a interpretação e a atualização ${ }^{572}$.

\footnotetext{
572 lbid., pp.147-149.
} 


\section{3 \\ O retorno ao dado bíblico do Novo Testamento}

Uma das principais críticas que se faz à definição de Calcedônia é exatamente o distanciamento do dado fundante do Novo Testamento ou, mais precisamente ainda, da linguagem kerigmática contida no texto neotestamentário, visto que aí kerigma e história caminham juntos. A crítica de fato, por um lado é válida quando consideramos que este distanciamento aumenta na medida em que o anúncio evangélico precisa dialogar com o ambiente e a cultura helenistas para se expandir. A cristologia contemporânea, pelo contrário, parte do dado bíblico, não se limita na análise de definições conciliares e desloca seu núcleo vital da encarnação para o mistério pascal. Contudo, por outro lado, como já salientamos, a crítica pode cair no anacronismos, haja vista que este mesmo afastamento histórico do kerigma neotestamentário, a influência sobre novas culturas, a força da filosofia helenista, especialmente do neoplatonismo, a necessidade de anunciar Cristo a essas novas culturas, a exegese que fizeram os Padres, especialmente do Antigo Testamento, a necessidade de combater as heresias, enfim, tudo isso exerceu capital importância no predomínio quase que absoluto da cristologia do Logos.

Somente a partir da Reforma Protestante é que se despertou um interesse mais aprofundado pela Sagrada Escritura. Do lado protestante procurava-se absolutizar a Sagrada Escritura como fonte única da teologia, ao passo que do lado católico, como medida apologética, procurava-se definir o cânon bíblico e reafirmar a Sagrada Escritura, a Tradição e o Magistério como fonte tríplice de toda a teologia. Deste embate, o dado positivo que deve ser ressaltado é o movimento de ambas as partes de colocar em debate o dado bíblico como lugar teológico, mesmo que cada um tenha interesses próprios e até mesmo opostos. O interesse pela letra bíblica se aprofunda mais ainda no século XIX tanto do lado protestante quanto do lado católico com estudos arqueológicos, literários, linguísticos, etc. É a partir daí que a Sagrada Escritura passa a ser valorizada também como documento.

A reflexão teológico-sistemática do século XX, como já apontamos, questionou profundamente a primazia das fórmulas dogmáticas, julgando-as demasiado estáticas, exageradamente helenistas e pouco kerigmáticas em comparação com a cristologia neotestamentária. Estes questionamentos após todo esse processo de valorização do dado bíblico para a investigação teológica, naturalmente reivindicam uma maior referência bíblica para a cristologia hodierna 
na abordagem das definições conciliares, de modo que as fórmulas de fé sejam lidas à luz dos textos bíblicos dos quais são interpretação, mais ainda quando se trata da definição calcedoniana, ainda hoje considerada a mais célebre de todas as definições conciliares, a referência fundamental para a fé em Jesus Cristo e uma síntese sensível e grandiosa, que vem caracterizando como nenhuma outra cristologia eclesiástica até os nossos dias ${ }^{573}$.

\section{4}

\section{O concílio de Calcedônia e o Ecumenismo}

Um dos maiores desafios hodiernos para os cristãos é o ecumenismo. De fato, buscar a unidade a despeito das diferenças e divisões não é tarefa fácil. Porém, é uma tarefa desafiante que brota do próprio desejo de Cristo (cf. Jo 21,17), e que é conduzido na força de seu Espírito no curso da história.

Ao longo da história dos concílios, percebe-se que aqueles que não aceitam o concílio mais recente se obstinam em um cisma em nome dos precedentes. $E$ Calcedônia não escapará desta "sina". Pois o concílio de 451 também não foi recebido por algumas igrejas, o que provocou o cisma duradouro das igrejas Copta, Armênia e Jacobita.

Porém, atualmente as lgrejas chamadas pré-calcedonianas, equivocadamente denominadas de monofisitas, são a Copta de Alexandria, a Armênia, a Síria, a Etíope, a Indiana e a Eritréia. O diálogo entre as Igrejas orientais calcedonianas e as pré-calcedonianas tem gerado progressos no sentido de um acordo cristológico, a despeito das diferenças terminológicas. E isso deve ser considerado algo a se comemorar haja vista as grandes dificuldades de aceitação encontradas pela fórmula de Calcedônia a partir de fatores não somente teológicos, mas também políticos, culturais e históricos ${ }^{574}$.

Seria arriscado chamar as Igrejas pré-calcedonianas de monofisitas, pois a rejeição à fórmula calcedoniana se deu mais por motivos de linguagem, ou seja, por problemas de interpretação da terminologia helenista entre povos que falavam outras línguas ${ }^{575}$.

Malgrado as dificuldades encontradas ao longo de aproximadamente mil e quinhentos anos, a Fórmula de Calcedônia possui um considerável potencial ecumênico e poderia ser utilizada como base do diálogo e da união das Igrejas pré-calcedonianas. Por isso, nas últimas décadas os papas Paulo VI e João Paulo

\footnotetext{
573 KÜNG, H. La encarnación de Dios., p.676.

574 AMATO, A. Gesù, il Signore., p.306.

575 HORTAL, J. E haverá um só rebanho., p.26.
} 
II assinaram uma série de confissões cristológicas em nível de declarações conjuntas com os patriarcas das várias igrejas pré-calcedonianas. O objetivo da Igreja Católica é, através destes documentos, procurar seguir o mais de perto possível as afirmações do Concílio de Calcedônia, porém, sem empregar a linguagem das duas naturezas e procurando exprimir por meio de um outro vocabulário a distinção entre a divindade e a humanidade de Cristo. Uma reconciliação doutrinal neste nível é de suma importância, pois mostra que na profissão de fé o conteúdo supera a linguagem, uma vez que esta tem a tarefa de expressar aquela. Neste sentido, mesmo que a linguagem utilizada na definição conciliar seja a mais elevada e apropriada, as igrejas são capazes de irem além da linguagem.

Por exemplo, em 1973 o papa Paulo VI assinou uma "declaração comum" com o patriarca de Alexandria Shenouda III da Igreja Ortodoxa Copta, também chamado de Papa de Alexandria, na qual se percebe a convergência da estrutura e dos termos com a fórmula calcedoniana ${ }^{576}$.

Dentre as denominações cristãs, duas delas estão mais diretamente ligadas à problemática da cristologia calcedoniana: a Igreja Nestoriana e as Igrejas Monofisitas.

\section{5}

\section{A Igreja Nestoriana}

Após o cisma nestoriano ocorrido na década de 430, como já afirmamos no primeiro capítulo do presente ensaio, o nestorianismo se tornou uma seita distinta. Nestório, já havia caído sob os ataques de Cirilo, que possuía tanto motivos teológicos como políticos para fazê-lo, visto que além de acreditar que seu pensamento estava equivocado, este representava a liderança de um patriarcado competidor. Cirilo e Nestório haviam pedido a intervenção do Papa Celestino I. Entendendo que o termo Theotókos era ortodoxo, o Papa autorizou que ambos se desculpassem. Contudo, Cirilo atacou ainda mais Nestório, que solicitou ao imperador Teodósio II que convocasse o concílio de Éfeso para dar fim à querela teológica. Porém, o concílio efesino de 431 acabou por apoiar Cirilo, e assim, Nestório foi acusado de heresia e deposto. O nestorianismo, como ficou conhecida sua doutrina, foi oficialmente anatemizado, e sua condenação foi posteriormente reforçada em Calcedônia (451). Todavia, muitas comunidades apoiaram Nestório,

${ }^{576}$ AMATO, A. Op.cit., p.307. 
afastando-se progressivamente da doutrina definida em Calcedônia e originando a chamada lgreja Nestoriana.

A Igreja Nestoriana possui o mérito de ter evangelizado a China e a Índia com notável sucesso, chegando ao final do séc. XIII com 50 milhões de fiéis, que foram dizimados no séc. XIV pelos mongóis, tártaros e turcos islamizados. Seus fiéis, atualmente, não passam de 200 mil no Irã, Iraque e sul da Índia ${ }^{577}$.

\section{6}

\section{A Igreja Monofisita}

A recepção do Concílio de Calcedônia e de sua fórmula dogmática encontrou muitas dificuldades. Ela foi condicionada pela rivalidade étnica e política entre o patriarcado de Constantinopla de um lado, e os de Antioquia e Alexandria de outro. A ingerência dos imperadores bizantinos tornou a situação mais crítica, sobretudo por ocasião do ambíguo Henótikon decretado pelo imperador Zenão e escrito pelo patriarca Acácio de Constantinopla, condenado pelo Papa Felix, o que dava ocasião ao primeiro cisma entre Roma e Constantinopla de 484 a 518, visto que o Papa e o patriarca mutuamente se excomungaram. As tentativas do imperador Justiniano de sanar o cisma foram inúteis.

Mas, foi ao longo do governo de Justiniano (+ 565) que se deu a consolidação da Igreja monofisita da Síria por obra do bispo Jacó Baradeu, protegido pela imperatriz Teodora. Daí o nome de lgreja jacobita, que existe até hoje na Síria, no Líbano e no sul da Índia. Sem admitirem a denominação de monofisitas, preferem ser chamados orientais ortodoxos. Trata-se de um monofisismo moderado do qual se pode duvidar que de fato negue a dupla natureza de Cristo após a encarnação.

Os monofisitas compreendiam o termo "natureza" de maneira diferenciada e até mesmo exclusiva; chegavam a admitir que Cristo fosse derivado de duas naturezas, mas não que subsistisse em duas naturezas, como queriam os calcedonianos, na medida em que consideravam tal afirmação equivalente à afirmação de duas pessoas, hipóstases, e, neste sentido, nestoriana. Precisamente por este motivo recusavam não somente a Fórmula de Calcedônia, como também o Tomus ad Flavianum.

No Egito a maioria dos fiéis aderiu ao monofisismo, principalmente por causa da condenação do patriarca Dióscoro de Alexandria pelo sínodo de Constantinopla. Acredita-se que sua condenação pode ter sido considerada pelos

\footnotetext{
577 HORTAL, J. E haverá um só rebanho., p.23s.
} 
egípcios como uma rejeição do Egito pelos bizantinos. Em 536, o patriarca Pedro IV de Alexandria começa a hierarquia copta, que perdura até o presente, com aproximadamente três milhões de fiéis. O monofisismo etíope foi em sua origem dependente do copta, e é professado até hoje por um terço da população etíope. A Igreja armênia, que não enviou delegados para o Concilio de Calcedônia, posteriormente o rejeitou explicitamente ${ }^{578}$.

\section{7}

\section{Diálogo e declarações ecumênicas}

O Concílio Vaticano II (1962-65) tinha por objetivo ser verdadeiramente um concílio "ecumênico" em toda a plenitude do termo, isto é, não somente no sentido tradicional de "universalidade" ou "catolicidade", mas num sentido hodierno de favorecer a unidade dos cristãos. Foi assim que o jornal L'Osservatore Romano de 26 de janeiro de 1959 publicou o primeiro aviso oficial sobre o Concílio:

Pelo que se refere à celebração de um Concílio Ecumênico, este, segundo o pensamento do Santo Padre, não somente tende à edificação do povo cristão, mas também quer ser um convite às Comunidades separadas para a busca da unidade pela qual hoje em dia muitas almas anseiam em todos os pontos da terra. ${ }^{579}$

Em um gesto de continuidade ao espírito do Concílio o Papa Paulo VI em 1971 assinou, juntamente com o patriarca Ignatius Jacob III da Igreja Siroortodoxa, uma declaração sobre o que há de comum entre ambas as Igrejas, com base na fé em Jesus Cristo, Verbo de Deus feito homem, fiéis à tradição apostólica, ao ensinamento dos Padres e Doutores, especialmente Cirilo de Alexandria, e à celebração dos sacramentos da fé580.

Inspirada pelo diálogo existente entre as lgrejas ortodoxas, a fundação ecumênica "Pro Oriente" expediu em 1971 às Igrejas calcedonianas e às Igrejas não-calcedonianas uma consulta sobre os pontos de vista cristológicos. No primeiro encontro os teólogos ortodoxos orientais e os teólogos católicos romanos atingiram um consenso cristológico, que foi aceito e abençoado pelos chefes das Igrejas $^{581}$. Eis a chamada Fórmula Cristológica de Viena:

\footnotetext{
578 lbid., p.26.

579 COMPÉNDIO DO VATICANO II., p.12

580 A referida declaração reconhece a profunda comunhão espiritual já existente entre as duas Igrejas, além da celebração dos sacramentos, da profissão de fé no Verbo de Deus encarnado e da tradição apostólica que faz parte do patrimônio comum entre ambas as Igrejas, incluindo ainda os grandes Padres e Doutores, entre eles Cirilo de Alexandria; cf. Declaração Comum do Papa Paulo VI e do Papa Ignatius lacob Mar.

581 KRIKORIAN, M. K. I/ Concílio de Calcedônia., p.9.
} 
Encontramos o nosso comum fundamento na mesma tradição Apostólica, especificamente o que é declarado no Credo Niceno-Constantinopolitano; nós todos professamos as decisões dogmáticas e as doutrinas de Nicéia (325), Constantinopla (381) e Éfeso (431); somos todos de acordo ao refutar tanto as posições eutiquianas, tanto as nestorianas sobre Jesus Cristo. Tentamos compreender de modo mais profundo as Cristologias calcedonenses e não-calcedonenses, que até o momento nos dividem. Cremos que nosso Senhor e Salvador, Jesus Cristo, é o Filho Encarnado de Deus; perfeito na Sua natureza divina e perfeito na Sua natureza humana. A Sua natureza divina não foi separada da Sua natureza humana por um só minuto, nem um piscar de olhos. A Sua natureza humana forma um todo com a Sua natureza divina, sem mistura, sem confusão, sem divisão, sem separação. Na nossa fé comum é apenas em Nosso Senhor Jesus Cristo consideramos o Seu mistério inexaurível e inefável e jamais inteiramente compreensível ou exprimível pela mente humana ${ }^{582}$.

Podemos perceber que a matriz desta declaração é a Fórmula de Calcedônia, de forma significativamente abreviada. Nota-se ainda a ocorrência dos quatro advérbios negativos que caracterizam a unidade do ser de Cristo e plena diversidade das naturezas.

Em 1973, Paulo VI assinou uma "Declaração Comum" com o patriarca de Alexandria Shenouda III, da Igreja Copta ortodoxa:

De acordo com nossas tradições apostólicas transmitidas às nossas lgrejas e nelas conservadas, e em conformidade com os três primeiros Concílios ecumênicos, confessamos uma única fé em um só Deus uno e Trino e na divindade do Filho Unigênito de Deus, a Segunda pessoa da Santíssima Trindade, o Verbo de Deus, o esplendor de Sua glória e a imagem manifesta de sua substância, que por nós se encarnou, assumindo para si um corpo real com uma alma racional, e que compartilha conosco a nossa humanidade, sem pecado. Confessamos que Nosso Senhor e Deus e Salvador e Rei de todos nós, Jesus Cristo, é Deus perfeito com relação à sua divindade, e homem perfeito com relação à nossa humanidade. Nele a sua divindade é unida à sua humanidade numa real, perfeita união sem mescla, sem mistura, sem confusão, sem alteração, sem divisão, sem separação. A sua divisão não se separou da sua divindade da sua humanidade nem por um instante, nem por um piscar de olhos. Ele, que é Deus eterno e invisível, se tornou visível na carne, e tomou sobre si a forma de um servo. Nele todas as propriedades da divindade e todas as propriedades da humanidade estão conservadas juntas em uma união real, perfeita, indivisível, inseparável ${ }^{583}$.

Novamente se nota que a teologia da fórmula calcedoniana subjaz nesta Declaração, sobretudo ao se assinalar a plena divindade e a plena humanidade de Cristo, inclusive com a ocorrência dos quatro advérbios negativos, acrescidos de outros dois "sem mescla" e "sem alteração". Não se confessa a união hipostática, contudo, percebe-se que esta noção também lhe é subjacente.

Em 1988, a comissão mista de diálogo entre a lgreja Católica e a lgreja Copta Ortodoxa aprovou a seguinte fórmula comum, a qual possui também significativos traços da Fórmula de Calcedônia:

\footnotetext{
582 lbid.

583 Declaração Comum do Papa Paulo VI e do Papa de Alexandria Shenouda III.
} 
Nós cremos que Nosso Senhor, Deus e Salvador Jesus Cristo, o Logos encarnado, é perfeito na sua divindade e perfeito na sua humanidade. Ele fez da sua humanidade uma coisa só com a sua divindade, sem mescla, nem mistura, nem confusão. A sua divindade não está separada de sua humanidade nem por um piscar de olhos. Ao mesmo tempo, nós anatematizamos a doutrina de Nestório e Éutiques ${ }^{584}$.

Nesta declaração se confessa a plena divindade, a plena humanidade e a união entre ambas as naturezas. Ocorrem apenas dois dos advérbios da Fórmula de Calcedônia, pois "sem mescla" e "sem mistura" significam a mesma coisa. Embora refute a cristologia de Nestório, não ocorrem os advérbios "sem separação" e "sem divisão", com os quais a Fórmula de Calcedônia refuta a heresia nestoriana.

Em 1984 o Papa João Paulo II se encontrou com Moran Mar lgnatius Zakka I Iwas, patriarca de Antioquia e de todo o oriente, chefe da Igreja Sírio Ortodoxa. Em um documento em conjunto ambos declararam.

Nas palavras de vida confessamos a verdadeira doutrina sobre Cristo, nosso Senhor, não obstante as diferenças de interpretação de uma doutrina que surgiu na época do Concílio de Calcedônia. Por isso queremos reafirmar solenemente a nossa profissão de fé comum, na encarnação de nosso Senhor Jesus Cristo, como o Papa Paulo VI e o Patriarca Mar Ignatius Moran Jacoub III fizeram em 1971. Eles negaram que houvesse qualquer diferença na fé que confessaram no mistério do Verbo de Deus feito carne e verdadeiramente homem. No nosso lado, confessamos que se encarnou por nós, tomando para si um verdadeiro corpo com uma alma racional. Ele partilhou a nossa humanidade em todas as coisas exceto no pecado. Confessamos que nosso Senhor e nosso Deus, nosso Salvador e Rei de todos, Jesus Cristo, é perfeito Deus em Sua divindade e perfeito homem em Sua humanidade. Nele Sua divindade está unida à Sua humanidade. Esta união é real, perfeita, sem mistura, sem confusão, sem modificação, sem divisão, sem o mínimo de separação. Ele que é Deus eterno e indivisível, se tornou visível na carne e tomou a forma de servo. Nele estão unidas de maneira real, indivisível, inseparável e perfeita a divindade e a humanidade, e nele todas as suas propriedades estão presentes e ativas ${ }^{585}$.

Ao contrário da Declaração anterior, esta Declaração, além de confessar a plena divindade e a plena humanidade, unidas em Cristo, ela refuta o nestorianismo utilizando as expressões "sem divisão" e "sem separação", presentes na Fórmula de Calcedônia.

Em 1990 foi publicada uma declaração pela comissão mista entre Católicos e Ortodoxos Sírio-Malancares ${ }^{586}$. E em 1994, João Paulo II e o patriarca Mar Dinka IV da Igreja Assíria do Oriente assinaram uma “Declaração Cristológica Comum”:

Como herdeiros e guardiães da fé recebida pelos Apóstolos, do modo como ela foi formulada pelos nossos Padres comuns no Credo de Nicéia, confessamos um só

${ }^{584}$ EO 3/2000 Apud AMATO, A. Gesù il Signore., p.307.

585 Declaração Comum do Papa João Paulo Ile do Patriarca Ecumênico de Antioquia Sua Santidade Moran Mar Ignatius Zakka I lwas.

${ }^{586}$ EO 3/2000 Apud AMATO, A. Op. cit., nota 68. 
Senhor Jesus Cristo, Filho Unigênito de Deus, nascido do Pai antes de todos os séculos, o qual tendo chegado a plenitude dos tempos, desceu do céu e se fez homem para a nossa salvação. O Verbo de Deus, a segunda Pessoa da Santíssima Trindade, pelo poder do Espírito Santo encarnou, assumindo da Santa Virgem Maria um corpo animado de uma alma racional, com a qual esteve indissoluvelmente unido desde o momento da sua concepção. Por isso, Nosso Senhor Jesus Cristo é verdadeiro Deus e verdadeiro homem, perfeito na sua divindade e perfeito na sua humanidade, consubstancial ao Pai e consubstancial a nós em todas as coisas, exceto no pecado. A sua divindade e a sua humanidade estão unidas numa única pessoa, sem confusão nem mudança, sem divisão nem separação. N'Ele foi preservada a diferença das naturezas da divindade e da humanidade, com todas as suas propriedades, faculdades e operações. Mas longe de constituir 'um e outro', a divindade e a humanidade estão unidas na pessoa do mesmo e único Filho de Deus e Senhor Jesus Cristo, o qual é objeto de uma só adoração. Portanto, Cristo não é um 'homem como os outros', que Deus teria adotado para residir nele e inspirá-lo, como é o caso dos justos e dos profetas. Pelo contrário, Ele é o próprio Verbo de Deus, gerado pelo Pai antes da criação, sem princípio no que se refere à sua divindade, nascido nos últimos tempos, de uma mãe sem um pai, no que se refere à sua humanidade. A humanidade que a Bem-aventurada Virgem Maria deu à luz foi sempre a do próprio Filho de Deus. Por esta razão, a Igreja Assíria do Oriente elevava as suas orações à Virgem Maria. Como 'Mãe de Cristo, nosso Deus e Salvador'. À luz desta mesma fé, a tradição católica dirige-se à Virgem Maria como 'Mãe de Deus' e também como 'Mãe de Cristo'. Nós reconhecemos a legitimidade e exatidão destas expressões da mesma fé e respeitamos as preferências que cada Igreja Ihes dá na sua vida litúrgica e na sua piedade. Esta é a única fé que nós professamos no Mistério de Cristo. As controvérsias do passado levaram a anátemas pronunciados a respeito de pessoas ou de fórmulas. O Espírito do Senhor concede-nos compreender melhor hoje que as divisões que se verificaram deste modo, eram em grande parte devidas a incompreensões. Contudo, prescindindo das divergências cristológicas que se verificaram confessamos hoje unidos a mesma fé no Filho de Deus que se fez homem para que nós, mediante a sua graça nos tornássemos filhos de Deus. Desejamos, de agora em diante, testemunhar juntos esta fé n'Aquele que é o caminho, a verdade e a vida, anunciando-a do modo mais idôneo aos homens do nosso tempo e para que o mundo creia no Evangelho da Salvação $[\ldots]^{587}$.

Nesta extensa Declaração percebemos os elementos constitutivos da Fórmula de Calcedônia, a dupla consubstancialidade, a confissão na plena humanidade e na plena divindade, que não se alteram após a união, e a união hipostática, caracterizada pelos quatro advérbios negativos.

A fórmula calcedoniana também serve como elemento de diálogo ecumênico com as denominações cristãs surgidas após a Reforma do séc. XVI. Por exemplo, pode-se recordar a "Declaração Comum" assinada em 1977 pelo Papa Paulo VI e o arcebispo de Cantuária Frederico D. Coggan, reconhecendo a fé em Deus nosso Pai, em Nosso Senhor Jesus Cristo, a participação nas Escrituras, nos símbolos de fé Apostólico, Niceno, a doutrina calcedoniana e o ensinamento dos Padres ${ }^{588}$. Iniciativa similar fizeram João Paulo II e o primaz

\footnotetext{
${ }^{587}$ L'Oss Rom. n. 49, p.3.

${ }^{588}$ Declaração Comum de Sua Santidade Papa Paulo VI e do arceb ispo de Canterbury, Sua Graça Frederick Donald Coggan.
} 
anglicano G. Carey que, em 1996, assinaram uma declaração ante o início do III milênio cristão $0^{589}$.

Em todas estas iniciativas e declarações, e, sobretudo nas citações transcritas, se pode perceber que a matriz subjacente é a Fórmula de Calcedônia, sobretudo ao se salvaguardar a divindade e a humanidade de Jesus Cristo, unidas na sua única pessoa. O espírito que guia a redação destas fórmulas é o da grande tradição da linguagem da fé.

Neste sentido, poderia se falar de uma nova recepção do Concílio de Calcedônia? É o que parece sugerir o documento da Comissão Plenária Fé e Constituição intitulado Concílio de Calcedônia: sua história, sua recepção pelas Igrejas e sua atualidade de 1959. Ao comentar o referido documento Yves Congar afirma:

No âmbito das atuais investigações cristológicas, que partem muito mais do Homem-Jesus dos evangelhos sinóticos, fala-se de uma "re-recepção do Concílio de Calcedônia. Calcedônia é ponto pacífico e não é posto em dúvida, contudo, em um novo contexto de visão cristológica e também de pesquisa ecumênica, deve-se efetuar uma nova leitura de sua história e de suas intenções profundas e, assim, a "receber" de novo 590.

Já Sesboüé tem reservas quanto a esta terminologia de "re-recepção". Pois o termo subentende que uma "re-recepção" poderia ser fruto de uma ação refletida e combinada de acordos oficiais entre as igrejas. Porém, não é isso o que acontece, até mesmo por causa do problema inevitável da distância histórica.

O processo de recepção tem lugar no decurso do espaço de tempo em que as Igrejas são ainda concretamente solidárias da problemática envolvida e do vocabulário empregado. Além desse limite não se pode falar mais de recepção. $\mathrm{O}$ mesmo vale para os concílios antigos. De fato, a autoridade deles não se dirige a nós da mesma maneira que os contemporâneos ${ }^{591}$.

Para Sesboüé o grande problema é a hermenêutica conciliar. O jesuíta francês entende que a distância histórica permiti distinguir melhor o que se pretende com a afirmação e com a linguagem. Sendo que nem sempre ambas estão em harmonia, ou uma a serviço da outra592.

Assim, a lgreja Católica acredita que a assinatura destas declarações conjuntas, que trazem consigo uma nova profissão de fé, é compatível com a sua própria recepção de Calcedônia. De modo que não é propriamente necessária a aceitação da linguagem e a confissão da fórmula cristológica de Calcedônia por

\footnotetext{
589 PASTOR, F.A. Semântica do Mistério., p.281.

590 CONGAR, Y. La "réception" comme réalité ecclésiologique., p.375.

591 SESBOÜÉ, B. O magistério em questão., p.99.

592 lbid.
} 
parte das igrejas pré-calcedonianas. Esta é uma via que a lgreja Católica encontrou para um novo processo de recepção do concílio. 


\section{8 \\ Referências bibliográficas}

\section{1}

\section{Fontes}

BÍBLIA. Português. Bỉblia de Jerusalém. São Paulo: Paulus, 2002.

BETTENSON, H. Documentos da Igreja Cristã. 3aㅡ ed. São Paulo: ASTE,1998.

COMPÊNDIO do Concílio Vaticano II. 29ª ed. Petrópolis: Vozes, 2000.

CLEMENTE ROMANO. Carta aos Coríntios. Disponível em: <http://www.ecristianismo.com.br/pt/historia/apostolicos/65-clemente-de-roma-aos-corintios $>$.

DENZINGER, H. Compêndio dos símbolos, definições e declarações de fé e moral. Trad. José Marino e Johan Konings. São Paulo: Paulinas: Edições Loyola, 2007.

DOCUMENTOS DOS PRIMEIROS OITO CONCÍLIOS ECUMÊNICOS. Porto Alegre: EDIPUCRS, 2000.

CIRILLO DI ALESSANDRIA. Epistole Cristologiche. Roma: Città Nuova, 1999.

EUSÉBIO DE CESARÉIA. História Eclesiástica. Patrística 15. São Paulo, Paulus, 2000.

IRINEU DE LION. Contra as Heresias. Patrística. São Paulo: Paulus, 1995.

JUSTINO. Dialogus cum Tryphonel. 60, 2. Disponível em: $<$ http://earlychristianwritings.com/text/justinmartyr-dialoguetrypho.html>.

LEONE MAGNO. Lettere Dogmatiche. Roma: Città Nuova, 1993.

NESTÓRIO. Ad Cyrillum, II, 3 In WICKHAM, L.R. Cyril of Alexandria: Select Letters. Oxford: Clarendon Press, 1983.

NESTÓRIO DE CONSTANTINOPLA. Liber Heraclidis, 1,2. In The Bazaar of Heracleides. Trad. G. R. Driver - L. Hodgson. Oxford 1925. Disponível em: <http://www.tertullian.org/fathers/nestorius_bazaar_1_book1_part1.htm >

TERTULIANO. Adversus Praxean 2. Disponível em: <http://www.intratext.com/IXT/ENG0272/_P2.HTM>.

Adv. Hermogenem 3. Disponível em:

<http://www.intratext.com/IXT/ENG0268/_P3.HTM> 


\section{2 \\ Documentos da Igreja}

COMISSÃO TEOLÓGICA INTERNACIONAL. Cuestiones selectas de cristología. Disponível em:

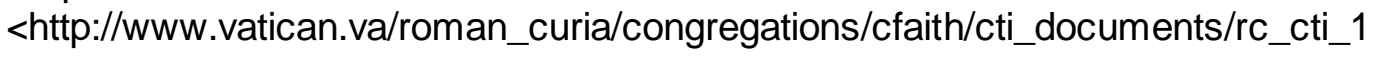
979_cristologia_sp.html>

DOCUMENTOS de Pio XII. São Paulo: Paulus, 1998.

JOÃO XXIII. Discurso de Sua Santidade Papa João XXIII. Disponível em: $<$ http://www.vatican.va/holy_father/john_xxiii/speeches/1962/documents/hf_jxxiii_spe_19621011_opening-council_po.html>.

PAULO VI. Mysterium Fidei. Disponível em: <http://w2.vatican.va/content/paulvi/pt/encyclicals/documents/hf_p-vi_enc_03091965_mysterium.html>.

PONTIFÍCIA COMISSÃO BÍBLICA. A Interpretação da Bỉblia na Igreja. São Paulo: Loyola, 1994.

VATICANO. Declaração comum de sua Santidade Papa Paulo VI e do Arcebispo de Canterbury, ua graça Frederick Donald Coggan. Disponível em: $<$ http://www.vatican.va/holy_father/paul_vi/speeches/1977/april/documents/hf_pvi_spe_19770429_dichiarazione-comune_it.html>.

Declaração comum do Papa João Paulo II e do Patriarca Ecumênico de Antioquia sua Santidade Moran Mar Ignatius Zakka I Iwas. Disponível em: $<$ http://www.vatican.va/holy_father/john_paul_ii/speeches/1984/june/documents/ hf_jp-ii_spe_19840623_jp-ii-zakka-i_en.html>.

Declaração comum do Papa Paulo VI e do Papa de Alexandria Shenouda Disponível $<$ http://www.vatican.va/roman_curia/pontifical_councils/chrstuni/anc-orient-chdocs/rc_pc_christuni_doc_19730510_copti_en.html>.

. Declaração comum do Papa Paulo VI e do Papa Ignatius lacob Mar III. Disponível $<$ http://www.vatican.va/roman_curia/pontifical_councils/chrstuni/anc-orient-chdocs/rc_pc_christuni_doc_19711025_syrian-church_en.html>.

\section{3}

\section{Obras}

ADAM, K. O Cristo da fé. São Paulo: [s.n], 1962.

ALBERIGO, G. (org.). História dos concilios ecumênicos. São Paulo: Paulus, 1995.

ALTANeR, B.; STUIBER, A. Patrologia. Trad. Monjas Beneditinas de São Paulo. Tit. original: Patrologie. São Paulo: Paulinas, 1972.

AMATO, A. Gesù il Signore. Bologna: EDB, 1999. 
ARDUSSO, F. Magisterio Ecclesiale - II servizio della Parola. Milano: San Paolo, 1997.

BACIOCCHI, J. Jesus Cristo nos debates dos homens. Trad. R.Frangiotti. Tit. original: Jésus Christ dans le débat des hommes. São Paulo: Paulinas, 1987.

BERDIAEV, N. El sentido de la historia: experiência de la filosofia del destino humano. Madrid: Encuentro, 1979.

BIHLMEYER, K; TUECHLE, H. História da Igreja. v. 1. Trad. E. Lima. Tit. original: Kirchengeschichte. São Paulo: Paulinas, 1964.

BOFF, L. Jesus Cristo Libertador. Petrópolis: Vozes, 1972.

A Trindade, a Sociedade e a Libertação. Petrópolis: Vozes, 1986.

BORDONI, M. Gesú di Nazaret Signore e Cristo. Saggio di cristologia sistemática. V. 3. Roma: Herder - Uiversità Lateranense, 1986.

BULGAKOV, S. N. L'Agnello di Dio. Il mistero del Verbo incarnato. Roma: Città Nuova, 1990.

CARDEDAL, O.G. Cristologia. Madri: B.A.C., 2001.

DOYON, J. Cristologia para o nosso tempo. Trad. A. G. Ferreira. São Paulo: Paulinas, 1970.

DUQUOC, CH. Cristologia. v.1. Trad. A.Fassini. Tit. original: Cristologie. São Paulo: Loyola, 1977.

DUPUIS, J. Introdução à Cristologia. Trad. A. Vannucchi. São Paulo, Loyola, 1999.

EVDOKIMOV, P. A mulher e a salvação do mundo. São Paulo: Paulinas, 1989.

La connaissance de Dieu selon la tradition orientale, l'enseignement patristique liturgique et iconographique. Lyon: Xavier Mappus, 1967, p. 36.

La nouveauté de l'Esprit: études de spiritualité. Bérgrolles: Abbaye de Bellefontaine, 1977.

- Le Christ dans la pensée russe. Paris: Cerf, 1970.

. L'Orthodoxie. Paris: Desclée de Brouwer, 1959.

. L'uomo icona di Cristo. Milano: Ancora, 2003.

. O Sacramento do Amor. São Paulo: Paulinas, 1989.

. O silêncio amoroso de Deus. Aparecida: Santuário, 2007.

. Une vision orthodoxe de la théologie morale: Dieu dans vie des hommes. Paris: Cerf, 2009.

FIGUEIREDO, F. A. Curso de Teologia Patrística. 3 v. Petrópolis: Vozes, 19841990. 
FIORENZA, F.S.; GALVIN, J.P. (Org.). Teologia Sistemática. v. I. São Paulo: Paulus, 1997.

FORTE, B. Jesus de Nazaré, história de Deus, Deus da história. Trad. L. J. Gaio. Tit. original: Gesù di Nazaret, Storia di Dio, Dio della Storia. São Paulo: Paulinas, 1985.

A Trindade como História. Trad. A. Macintyre. Tit. original: Trinità come storia. São Paulo: Paulinas, 1987.

FRANGIOTTI, R. História das Heresias. São Paulo: Paulinas, 1995.

GALOT, J. Chi sei tu, o Cristo? Firenze: Fiorentina, 1980.

GAVRILYUK, P. El sufrimiento de Dios impassible. Salamanca: Sígueme, 2005.

GOMES, C. F. Antologia dos Santos Padres. São Paulo: Paulinas, 1973.

A Doutrina da Trindade Eterna. Rio Janeiro: Lumem Christi, 1979.

Riquezas da Mensagem Cristã. 2.a ed. Rio Janeiro: Lumem Christi, 1989.

GONZALES, C.I. El es nuestra salvacion - Cristologia e Soteriologia. Bogota: CELAM, 1986. 1986.

El desarollo dogmatico en los Concilios Cristologicos. Bogota: CELAM,

GRABMANN, M. Historia de la Teología Católica. Trad. esp. D. Gutierrez. Tit. original: Die Geschichte der Katholischen Theologie. Madrid: Espasa-Calpe, 1946.

GREER, R. A. Theodore of Mopsuestia: Exegete and Theologian. Westminster: [s.n.], 1961.

GRILLMEIER, A. Gesù il Cristo nella fede della chiesa. v.l/1: Dall' età apostolica al Concilio di Calcedonia (451). Trad. E. Norelli e S.Olivieri. Brescia:Paideia, 1982.

Gesù il Cristo nella fede della chiesa, v.l/2: Dall' età apostolica al Concilio

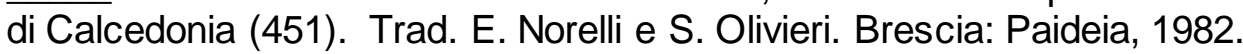

Gesù il Cristo nella fede della chiesa, v.ll/1: La ricezione del Concilio di Calcedonia (451-518). Trad. S. Olivieri. Brescia: Paideia, 1996.

Hermeneutica moderna e cristologica antiga. Trad. M. Angilletta. Brescia: Queriniana, 1985.

HAMMAN, A. Os Padres da Igreja. Trad. I. Ferreira. Tit. original: Les Pères de l'Eglise. São Paulo: Paulinas, 1980.

HENSE, A. I/ grande libro dei Concilii Ecumenici. Trad. P.Rossano. Tit. original: Das Grosse Konzilienbuch. Roma: Paoline, 1962.

HOFFMANN, F. A evolução histórica da fé em Cristo. Teologia para o Cristão de Hoje, v. 2. São Paulo: Loyola, 1975, pp. 207-253.

HORTAL, J. E haverá um só rebanho. São Paulo: Loyola, 1989. 
JEDIN, H. Concilios Ecumênicos. Trad. N. Boér. Tit. original: Kleine konziliengeschichte. São Paulo: Herder, 1961.

KASPER, W. Jesús el Cristo. Salamanca: Sígueme, 2012.

KESSLER, H. Cristologia. In SCHNEIDER, T. (org.). Manual de Dogmática. v. I, Petrópolis, Vozes, 2000.

KNOWLES, D.; OBOLENSKY, D. Nova História da Igreja. v. II. Trad. J. F. Hauck. Petrópolis: Vozes, 1974.

KOUBETCH, V. Da criação à parusia: Linhas mestras da teologia cristã oriental. São Paulo: Paulinas, 2004.

KRIKORIAN, M. K. I/ Concilio de Calcedônia - Storia, Confliti e Riconziliazione. Mimeo.

KÜNG, H. Essere Cristiani. Milão: Bur Rizzoli, 2011.

La encarnación de Dios. Barcelona: Herder, 1974.

LIÉBAERT, J. Os Padres da Igreja. v. 1. 2ª São Paulo: ed. Loyola, 2000.

LLORCA, J. et all. Historia de la Iglesia Catolica. v. I. Madrid: BAC, 1950.

LOSSKY, V. La teologia mística dela Chiesa d'Oriente. Bologna: Edizioni Dehoniane Bologna, 2013.

MANZANARES, C.V. Dicionário de Patrística. Trad. F.Costa. Tit. original: Diccionario de Patrística. Aparecida: Santuário, 1995.

MARROU, H; DANIELOU, J. Nova História da Igreja. v. I. Trad. P. E. Arns. Tit. original: Nouvelle Histoire de L'Eglise. Petrópolis: Vozes, 1966.

MEYENDORFF, J. Teología Bizantina: corrientes históricas y temas doctrinales. Madrid: Ediciones Cristiandad, 2003.

MCGUCKIN, J. Cyril of Alexandria: Christological Controversy. Its History, Theology, and Texts. Leiden: [s.n], 1994.

MOINGT, J. O homem que vinha de Deus. São Paulo: Ed. Loyola, 2008.

MOLTMANN, J. O Deus crucificado - A cruz de Cristo como base e crítica da teologia cristã. Trad. Juliano Borges de Melo. Santo André: Academia Cristã, 2014.

Trindade e Reino de Deus - Uma contribuição para a Teologia. Trad. I.Martinazzo. Tit. Original: Trinität und Reich Gottes. Petrópolis: Vozes, 2000.

Teologia da esperança: estudos sobre os fundamentos e as consequências de uma escatologia cristã. Trad. Helmuth Alfredo Simon; revisão Nélio Schneider. 3ª ed. São Paulo: Editora Teológica: Edições Loyola, 2005.

MORESCHINI, C.; NORELLI, E. História da Literatura Cristã Antiga Grega e Latina. 2v. Trad. M.Bagno. Tit. original: Storia della letteratura cristiana greca e latina. São Paulo: Loyola, 1996-2000. 
ORBE, A. Cristologia Gnóstica: introduccion a La soteriologia de los siglos II e III. Madrid: [s.n.], 1976.

OTT, L. Manual de Teologia Dogmatica. Barcelona: Herder, 1986.

PADOVESE, L. Introdução à Teologia Patrística. Trad. O. S. Moreira. Tit. original: Introduzione alla Teologia Patristica. São Paulo: Loyola, 1999.

PANNENBERG,W. Antropología em perspectiva teológica. Salamanca: Sígueme, 1991.

Fundamentos de Cristología. Salamanca: Sígueme, 1973.

Esquisse d'une christologie. Tradução do alemão por A. Liefooghe. Paris: Les Éditions du Cerf, 1971. 1996.

. Teología Sistemática, vol. II. Madrid: Pontificia Universidad de Comillas,

PASTOR, F. A. Semântica do Mistério - A linguagem teológica da ortodoxia trinitária. São Paulo: Loyola-PUCRJ, 1982.

PERRELLA, G.M.; VAGAGGINI, L. Elementos de História da Exesege Bíblica. In: V.AA. Introdução à Bíblia. v. I. Petrópolis: Vozes, 1978.

PERRONE, L. De Nicéia a Calcedônia. In ALBERIGO, G. (Org.) História dos Concilios Ecumênicos. São Paulo: Paulus, 1995.

PIOPPO, P. Cristologia. Casale: PIEMME, 1997.

QUASTEN, J. Patrologia. 2v. Tit. original inglês: Patrology. Madrid: BAC, 1952.

RAHNER, K. Curso Fundamental da Fé. São Paulo: Paulinas, 1989.

RUIZ BUENO, D. Padres Apostólicos. Madrid: BAC, 1965.

SARTORI, A. II concetto di Ipostasi e l'enosi dogmatica ai Concilii di Efeso e Calcedonia. Roma: Marietti, 1927.

SCHEFFCZYK, L. Formulação Magisterial e História do Dogma da Trindade. In FEINER, J.; LOEHRER, M. (org.). Mysterium Salutis. v.Il/1. Petrópolis: Vozes, 1971.

SCHILLEBEECKX, E. Esperienza umana e fede in Gesù Cristo: un breve bilancio. Brescia: Queriniana, 1985. Jesus, a história de um vivente. São Paulo: Paulus, 2008. . L’approccio a Gesú di Nazaret. Brescia: Queriniana,1972. . La questione cristologica. Un balancio. 2ªed. Brescia 1985.

SCHILSON, A.; KASPER, W. Cristologia -Abordagens Contemporâneas. Trad. Luiz João Baraúna. São Paulo: Loyola, 1990.

SChOONENBERG, P. Il est le Dieu des hommes. Paris: Éd. Du Cerf, 1973. 
SERENTHÀ, M. Jesus Cristo ontem, hoje e sempre. Trad. I.F.L.Ferreira. Tit. original: Gesù Cristo ieri, oggi e sempre. São Paulo: Salesiana, 1986.

SESBOÜÉ, B. Gesù Cristo nella Tradizione della Chiesa. Trad. A. Poltroniere. Tit. original: Jésus-Christi dans la tradicion de l'Eglise. Milano: Paoline, 1987.

História dos Dogmas. t. I: O Deus da Salvação. Trad. M. Bagno. Tit. original: Histoire des Dogmes. São Paulo: Loyola, 2002.

- Jésus-Christ dans la Tradition de l'Eglise. Pour une actualisation de la christologie de Chalcédoine. Paris: Desclée, 1982.

O magistério em questão: autoridade, verdade e liberdade na Igreja. Trad.: Ephraim F. Alves. Petrópolis: Vozes, 2004.

SMULDERS, P. Evolução da Cristologia na História dos Dogmas e no Magistério Eclesiástico. In FEINER, J; LOEHRER, M. (org.). Mysterium Salutis. v. III/3. Petrópolis: Vozes, 1973.

SOBRINO, J. A fé em Jesus Cristo- Ensaio a partir das vítimas. Petrópolis: Vozes, 2000.

Cristologia a partir da América Latina. Trad. O. Bernandi. Petrópolis: Vozes, 1983.

A fé em Jesus Cristo - Ensaio a partir das vítimas. Trad. E. F. Alves. Petrópolis: Vozes, 2000.

SPANNEUT, M. Os Padres da Igreja. vol. 2. São Paulo: Loyola, 2002.

STUDER, B. Dios Salvador en los Padres de la Iglesia. Trad. A. O. Garcia. Tit. original: Gott und unsere Erlösung im Glauben der Alten Kirche. Salamanca: S.Trinitario, 1993.

TANNER, N. P. I Concilii della Chiesa. Trad. C.Coveri. Milano: Jaca Book, 1999.

TERRA, J. E. M. O Jesus Histórico e o Cristo querigmático. São Paulo: Loyola, 1978. 2. ${ }^{a}$ ed revista.

Releitura Cristã e Judaica da Bỉblia. São Paulo: Loyola, 1988.

TILLICH, P. Teologia Sistemática. 5ª ed. São Leopoldo: Sinodal, 2005.

YANNOPOULOS, P.A. Do segundo Concílio de Constantinopla ao segundo Concílio de Nicéia. In ALBERIGO, G. (Org.). História dos Concilios Ecumênicos. São Paulo, Paulus, 1995.

VON BALTHASAR, H. U. Massimo il Confessore, Liturgia cósmica. Milano: Jaca Book, 2001. Solo l'amore è credibile. Roma: Borla, 2002.

WALKER, W. História da Igreja Cristã. v. I. Trad. G. V. Santos; N. D. Silva. Tit. original: A History of the Christian Church. São Paulo: ASTE, 1967. 
ŽAK, L. Trindade e imagem: aspectos da teologia mística de Vladimir Losskij. Org. Márcio Luiz Fernandes. São Paulo: Ave Maria, 2012.

\section{4}

\section{Artigos}

BAVEL, T. O significado de Calcedônia ontem e hoje. Concilium, Petrópolis, n. 173, 1982, pp. 79-88.

CONGAR, Y. La "réception" comme réalité ecclésiologique. Revue des Sciences philosophiques et théologiques 56, 1972, p. 375.

DE FRAINE, J. Logos. In VV.AA. Dic. Enc. da Bíblia. Petrópolis: Vozes.

DI BERARDINO, A. (Org.). Dicionário Patrístico e de Antiguidades Cristãs. Trad. Cristina Andrade. Petrópolis: Vozes, 2002.

EVDOKIMOV, P. Mystère de la personne humaine. Contacts, v. 21, pp. 272-289, 1969.

GALVIN, J. P. Jesus Cristo. In FIORENZA, F.S.; GALVIN, J.P. (org.) Teologia Sistemá-tica. v. I. São Paulo: Paulus, 1997, pp. 327- 425.

GAVRILYUK P. Theopatheia: Nestorius's main charge against Cyril of Alexandria. Scottish Journal of Theology, 56, 2003, pp 190-207.

GEISELMANN, J.R. Jesus Cristo. In VV.AA. Dicionário de Teologia. v. 3. [s.l: s.n], 19??, pp. 40-75.

HAMER, J. Mistero di Cristo e mistero dell'uomo. In Cristologia e catechesi patristica, v. 2. Roma: LAS, 1980, pp. 173-178.

KASPER, W. II dogma cristologico di Calcedonia. Asprenas 31 (1984), pp. 119122.

LATOURELLE, R. Bultmann, Rudolf. In: Dicionário de Teologia Fundamental. [s.l: S.n], 19??, pp. 116-119.

NORMANN, F. Alejandría. Escuola Teológica de. Sacramentum Mundi. v. I, pp. 84-90.

RIBEIRO, A.L.V. A Cristologia de S. Máximo Confessor. Teo, n. 111, 1996, Porto Alegre, pp. 45-61.

Os Concílios Trinitários. Teo, n. 121, 1998, Porto Alegre, pp. 321-338.

SCHMAUS, M. Trindade. In VV.AA. Dicionário de Teologia. São Paulo: Loyola, 1987, 2a. ed. v. 5. pp. 363- 382.

SESBOÜÉ, B. Le Procès Contemporain de Chalcedoine, Bilan et Perspectives. In Revue du Etudies et Sciences Religieuses 65/1 (1977), p. 55. 
SIMONETTI,M., A. Adocionistas. In DI BERARDINO, A. (Org.). Dicionário Patrístico e de Antiguidades Cristãs. Trad. Cristina Andrade. Petrópolis: Vozes, 2002, p. 43.

TERRA, J.E.M. Prólogo de São João (1,1-18). RCB 89/90, 1990, p. 11-21. 